

\title{
Práticas de Ensino e Tecnologias Digitais
}

\author{
Simone Dália de Gusmão Aranha
}

Fábio Marques de Souza

(orgs.)

\section{SciELO Books / SciELO Livros / SciELO Libros}

ARANHA, S. D. G., and SOUZA, F. M., eds. Práticas de ensino e tecnologias digitais [online]. Campina Grande: EDUEPB, 2018, 417 p. Ensino e aprendizagem collection, vol. 3. ISBN: 978-85-78795-26-9. http://doi.org/10.7476/9786586221657.

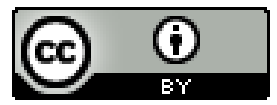

All the contents of this work, except where otherwise noted, is licensed under a Creative Commons Attribution 4.0 International license.

Todo o conteúdo deste trabalho, exceto quando houver ressalva, é publicado sob a licença Creative Commons Atribição 4.0.

Todo el contenido de esta obra, excepto donde se indique lo contrario, está bajo licencia de la licencia Creative Commons Reconocimento 4.0. 


\section{PRÁTICAS DE ENSINO E TECNOLOGIAS DIGITAIS}

Coleção Ensino \& Aprendizagem

VOLUME 3 


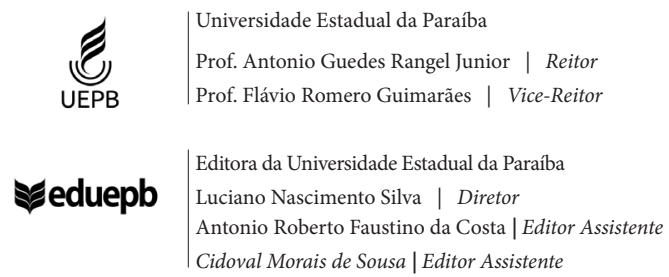

\section{Conselho Editorial}

Luciano do Nascimento Silva (UEPB)

Antônio Roberto Faustino da Costa (UEPB)

Cidoval Morais de Sousa (UEPB)

José Luciano Albino Barbosa (UEPB)

Antônio Guedes Rangel Junior (UEPB)

Flávio Romero Guimarães (UEPB)

\section{Conselho Científico}

Raffaele de Giorgi (UNISALENTO/IT)

Jorge Eduardo Douglas Price (UNCOMAHUE/ARG)

Celso Fernandes Campilongo (USP/ PUC-SP)

Juliana Magalhães Neuewander (UFRJ)

Vincenzo Carbone (UNINT/IT)

Vincenzo Milittelo (UNIPA / IT)

Jonas Eduardo Gonzalez Lemos (IFRN)

Eduardo Ramalho Rabenhorst (UFPB)

Gonçalo Nicolau Cerqueira Sopas de Mello Bandeira (IPCA/PT)

Gustavo Barbosa Mesquita Batista (UFPB)

Rodrigo Costa Ferreira (UEPB)

Glauber Salomão Leite (UEPB)

Germano Ramalho (UEPB)

Dimitre Braga Soares de Carvalho (UFRN)

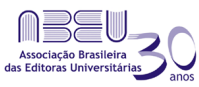

Editora filiada a ABEU

EDITORA DA UNIVERSIDADE ESTADUAL DA PARAÍBA

Rua Baraúnas, 351 - Bairro Universitário - Campina Grande-PB - CEP 58429-500

Fone/Fax: (83) 3315-3381 - http://eduepb.uepb.edu.br - email: eduepb@uepb.edu.br 
SIMONE DÁLIA DE GUSMÃO ARANHA FÁBIO MARQUES DE SOUZA

(Organizadores)

\section{PRÁTICAS DE ENSINO E TECNOLOGIAS DIGITAIS}

Coleção Ensino \& Aprendizagem

VOLUME 3

Campina Grande 2018 


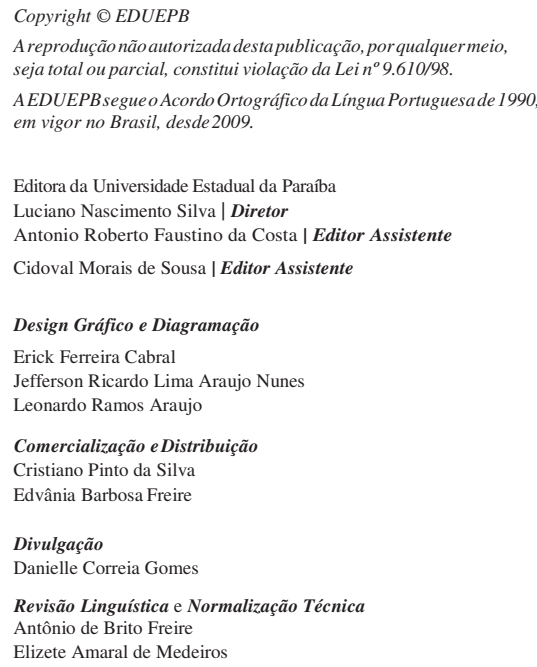

Depósito legal na Biblioteca Nacional, conforme decreto n 1.825 , de 20 de dezembro de 1907.

\subsection{8}

P912Práticas de ensino etecnologias digitais. Simone Dália de Gusmão Aranha, Fábio Marques de Souza (Organizadores). -Campina Grande: EDUEPB, 2018.

518 p.: il. (Coleção Ensino \& Aprendizagem, v.3)

ISBN 978-85-7879-525-2

ISBN E-BOOK 978-85-7879-526-9

Modo de Acesso: http://www.uepb.edu.br/ebooks

1. Tecnologia educacional. 2. Educomunicação. 3. Videocast - Oralidade. 4.Hipertexto. 5.Práxis educativo-coletiva. 6. Educação infantil - Sexismo. 7.Quilombolas Matão-PB Práticas de ensino. I.Aranha, Simone Dália de Gusmão (Org.). II. Souza, Fábio Marques de (Org.).

Ficha catalográfica elaborada por Heliane Maria Idalino Silva - CRB-15³68

\section{EDITORA DA UNTVERSIDADE ESTADUAL DA PARAÍBA}

Rua Baraúnas, 351 - Bodocongó - Bairro Universitáno Campina Grande-PB - CEP 58429-500

Fone/Fax: (83) 3315-3381 - http://eduepb.uepb.edu.br e-mail: eduepb@uepb.edu.br 


\section{Coleção Ensino \& Aprendizagem}

\section{Editores}

Fábio Marques de Souza

Simone Dália de Gusmão Aranha

\section{Conselho Científico}

Afrânio Mendes Catani (USP)

Alexsandro da Silva (UFPE)

Carla Luciane Blum Vestena (UNICENTRO)

Cesar Aparecido Nunes (UNICAMP)

Eduardo Gomes Onofre (UEPB)

Iraíde Marques de Freitas Barreiro (UNESP)

José Francisco de Melo Neto (UFPB)

Laura Janaina Dias Amato (UNILA)

Lucinalva Andrade Ataide de Almeida (UFPE)

Luiz Francisco Dias (UFMG)

Maria Helena Vieira Abrahão (UNESP)

María Isabel Pozzo (IRICE-Conicet- UNR, Argentina)

Marta Lúcia Cabrera Kfouri Kaneoya (UNESP)

Mona Mohamad Hawi (USP)

Rosa Ana Martín Vegas (USAL, Espanha)

Selma de Cássia Martinelli (UNICAMP)

Sinara de Oliveira Branco (UFCG) 


\section{Apresentação da Coleção}

A Coleção Ensino \& Aprendizagem visa à publicação e à divulgação de pesquisas desenvolvidas no âmbito do Programa de Pós-Graduação em Formação de Professores da Universidade Estadual da Paraíba - PPGFP/UEPB, assim como investigações de outros programas de pós-graduação do Brasil e do mundo. Os eixos norteadores estão ancorados em duas linhas de pesquisa, a saber: "Linguagens, Culturas e Formação Docente" e "Ciências, Tecnologias e Formação Docente", que subsidiaram as discussões, o desenvolvimento e os resultados das pesquisas realizadas.

Nesta Coleção, várias perspectivas de estudos direcionados a ações pedagógicas entram em cena. A partir dessa postura dialética, o PPGFP vislumbra promover reflexões teóricas e práticas a professores da Educação Básica e do Ensino Superior, que estejam em atividade e em formação inicial e continuada, buscando aperfeiçoar a sua prática docente, por meio de discussões acerca do complexo processo de ensino-aprendizagem. Busca, então, estimular professores, pesquisadores e demais profissionais envolvidos com a Educação e áreas afins, a fomentar um diálogo com a docência e suas práticas interculturais com vistas à produção do conhecimento científico. 


\section{SUMÁRIO}

11 Prefácio

Prof. Dr. Valdir Silva

17 Apresentação

Marcelo Medeiros da Silva

27 Desenvolvendo a oralidade no ensino básico:

o videocast em sala de aula

Geizielle Nathália F. Athouguia

Luiz Francisco Dias

55 O uso das NTICS em sala de aula de língua inglesa: o caso do aplicativo de mensagem, via aparelho móvel celular

Jordânia Virgínio dos Santos

Ivandilson Costa 
91 Softwares Aplicativos como recursos didáticos: a inserção de tecnologias digitais no contexto escolar Iara Costa Nascimento

Simone Dália de Gusmão Aranha

113 Diário de Classe: estudo das postagens de uma aluna de escola pública no Facebook Joana Rodrigues Moreira-Lima

Dánie Marcelo de Jesus

143 O cinema como artefato semiótico mediador da compreensão e potencialização dos processos de ensino-aprendizagem

Fábio Marques de Souza

181 O Gênero curta metragem como objeto de ensino e aprendizagem da leitura e da produção textual Roseane Batista Feitosa Nicolau Jeane dos Santos

213 Hipertexto: a força propulsora para o ensino de leitura e escrita na aula de língua portuguesa Anahy Zamblano 
239 A interação em ambiente virtual de aprendizagem: um estudo de caso Aline Tavares Costa

Filomena Maria Gonçalves da Silva Cordeiro Moita

277 Educomunicação no espaço da educação formal: atividades interdisciplinares Lígia Beatriz Carvalho de Almeida Roseane Andrelo Mariana Pícaro Cerigatto

319 Formação de professores e práxis educativocoletiva

Antonio Roberto Faustino da Costa José César dos Santos Pedro Bergamo

363 O papel da formação de professores no combate ao sexismo em sala de aula na educação infantil

Arilane Florentino Félix de Azevêdo

Tânia Maria Augusto Pereira

393 O lugar da escrita no cotidiano do professor do ensino fundamental I: o que revelam os discursos

Tatiana Dias Ferreira

Maria de Lourdes da Silva Leandro 
429 A leitura na educação de jovens e adultos

Rosely de Oliveira Macário

Linduarte Pereira Rodrigues

469 Memórias dos idosos quilombolas do Matão/ PB: narrativas para o desenvolvimento de práticas de ensino

Marta Oliveira Barros

João Batista Gonçalves Bueno

499 Travessias e desafios da introdução dos estudos da língua portuguesa no Egito Maged Talaat Mohamed Ahmed Elgebaly 


\title{
PREFÁCIO
}

\author{
Prof. Dr. Valdir Silva ${ }^{1}$
}

A visão dicotômica entre as práticas sociais produzidas no contexto offline (real) e online (virtual), definitivamente, não faz mais sentido no mundo contemporâneo. Estamos vivendo um contexto de práticas sociais híbridas

1 Graduado em Letras (UNEMAT), mestre em Linguística Aplicada (UNICAMP) e doutor em Linguística Aplicada (UFMG). Professor do Curso de Letras, Campus de Cáceres-MT, e do Programa de Pós-Graduação em Linguística da Universidade do Estado de Mato Grosso. Participa do Núcleo de Pesquisa em Linguagem e Tecnologia do Centro de Estudos e Pesquisas em Linguagem (CEPEL/UNEMAT), do GT Linguagem e Tecnologia da ANPOLL e é líder do Grupo de Pesquisa Linguagem, Tecnologia e Contemporaneidade em Linguística Aplicada (LINTECLA). Coordena o subprojeto PIBID-Inglês/CAPES e o projeto de Pesquisa/CNPq Linguagem, redes sociais e dispositivos móveis: resiliência e adaptações nas práticas de ensino e de aprendizagem contemporâneas. Tem como foco de estudo os efeitos das tecnologias digitais nas práticas de linguagem e na formação de professores da área da Linguagem, na perspectiva da teoria dos Sistemas Adaptativos Complexos. 
em razão do encurtamento, cada vez mais acentuado, entre o que vivenciamos e produzimos na sociedade, em decorrência dos avanços alcançados pelas tecnologias da informação e da comunicação nos últimos 25 anos.

Trata-se de um fenômeno que confere à sociedade atual uma natureza ainda mais dinâmica e complexa e na qual precisamos nos reorganizar e adaptar, pois, dada a sua força, está nos compelindo para que (res)signifiquemos nossas práticas sociais, ideias, conceitos, interpretação e nos impondo novas experiências no saber, no fazer, no sentir, no pensar etc. Em outras palavras, já não temos mais como nos sustentarmos em estruturas institucionais e práticas sociais historicamente sedimentas na cultura humana, pois elas estão se liquefazendo a cada dia, como argumenta Bauman (2001).

A era da informação, caracterizada pela convergência tecnológica e a informatização total de praticamente todas as esferas da sociedade contemporânea, como observa Castells (1996), é agora denominada por era das conexões, como afirma Weinberger (2003), como resultado da emergência e popularização das tecnologias móveis, representada de forma inequívoca pelo smartphone.

Lemos (2003) aponta o celular como o responsável pela radicalização da convergência digital, um teletudo para a gestão móvel e informacional do quotidiano:

[...] um equipamento que é ao mesmo tempo telefone, máquina fotográfica, televisão, cinema, receptor de informações jornalísticas, difusor de e-mails e SMS7, WAP8, atualizador de sites (moblogs), localizador por GPS, tocador de música 
(MP3 e outros formatos), carteira eletrônica. Podemos agora falar, ver TV, pagar contas, interagir com outras pessoas por SMS, tirar fotos, ouvir música, pagar o estacionamento, comprar tickets para o cinema, entrar em uma festa e até organizar mobilizações políticas e/ ou hedonistas (caso das smart e flash mobs).

Essa conectividade propiciada pelo smartphone, em particular, pode ser verificada nos resultados apresentados pela Pesquisa Nacional por Amostra de Domicílios (PNAD/IBGE), realizada em 2016, sobre o acesso à internet e ao uso de smarphones no Brasil. De acordo com a pesquisa, a internet estava presente em $63,6 \%$ dos lares e em $94,8 \%$ deles havia celulares sendo usados para se conectar à rede, enviando ou recebendo mensagens de texto, voz ou imagens por aplicativos, o que inclui redes sociais, como Facebook, Instagram, Twitter e programas de mensagem, como Whatsapp.

Parte dessas pessoas utiliza essas tecnologias digitais nas instituições educacionais (escolas e universidades) e, de alguma forma, interfere nas práticas de interações sociais e, consequentemente, nas práticas de ensino e de aprendizagem. Nas palavras de Paiva (2017),

[...] as tecnologias digitais estão definitivamente integradas em nossas vidas e ninguém mais tem dúvidas da necessidade de sua integração em nossas práticas pedagógicas. [...] 
muitos são os motivos para usarmos as tecnologias digitais em sala de aula e o principal deles é o fato de fazerem parte de nossa vida cotidiana, pois os computadores, tabletes e celulares conectados à Internet se tornaram uma extensão de nós mesmos. A sala de aula não pode ignorar esses novos hábitos mediados pela Internet.

Os efeitos dessas tecnologias nas práticas de ensino têm crescido exponencialmente e muitos desses trabalhos têm ganhado visibilidade em produções bibliográficas, como se pode verificar nos trabalhos na área da Linguagem produzidos por Araújo e Leffa (2016), Barton e Lee (2015), Coscarelli (2016), Buzato (2016), Dias e Couto (2011), Silva e Borges (2016), Jesus e Maciel (2015), Rojo e Barbosa (2015), entre tantos outros disponíveis na internet. Somam-se, a essas publicações, inúmeras pesquisas e apresentações em eventos acadêmicos da área da Linguagem sobre práticas de ensino e de aprendizagem mediatizadas.

Nesse sentido e reverberando esse movimento apontado acima, torna-se muito pertinente a proposta do Volume 3 da Coleção Ensino \& Aprendizagem, organizado por Simone Dália de Gusmão Aranha e Fábio Marques de Souza (PPGFP/UEPB), em assegurar a publicação de trabalhos resultantes de pesquisas sobre Práticas de Ensino e Tecnologias Digitais.

Nessa edição, o leitor terá acesso a 16 capítulos produzidos por pesquisadores da área da Linguística, Letras e Artes de diferentes partes do Brasil. Em sintonia com 
o tema da Coleção, 8 capítulos apresentam resultados de pesquisas relacionadas diretamente com práticas de ensino mediadas por tecnologias relacionadas com dispositivos móveis, videocast, whatsApp, vídeos, softwares, Facebook, cinema, hipertextualidade e ambiente virtual de aprendizagem. Os outros 8 capítulos, ainda que não relacionados diretamente com tecnologias digitais, apresentam reflexões muito instigantes sobre formação de professores e práticas de ensino na Educação Básica entre outros temas.

É importante ressaltar que não é propósito da Coleção discutir os efeitos positivos ou negativos das tecnologias digitais no âmbito das práticas de ensino, mas sim, um convite para que, livres de qualquer pré-conceito, possamos, com serenidade, observar, interpretar e compreender os fenômenos linguísticos que estão emergindo na sociedade contemporânea por força das tecnologias digitais e afetando de forma decisiva as práticas sociais e consequentemente de língua(gem).

É uma provocação para repensarmos sobre a necessidade premente de atualizarmos as matrizes curriculares vigentes nas universidades, em especial nos cursos de licenciatura, e na Educação Básica, visando ao alinhamento de suas práticas com as novas demandas sociais. Em síntese, não podemos mais negligenciar o fato de termos de reinventar essas instituições e para que isso ocorra, precisamos rever as práticas de ensino e de aprendizagem nelas produzidas, sem a pretensão de apagarmos o velho, o arcaico, como nos lembra Agamben (2006), mas de ressignificá-las e de atualizá-las no contemporâneo.

Boas leituras!!! 



\section{APRESENTAÇÃO}

\section{Marcelo Medeiros da Silva ${ }^{1}$}

Terceiro volume da Coleção Ensino e Aprendizagem, Práticas de ensino e tecnologias digitais vem reiterar o compromisso do Programa de Pós-Graduação em Formação de Professores em fazer da docência campo de reflexão científica e, a partir dos trabalhos de seus alunos e docentes, ressignificar o magistério no âmbito superior ou na educação básica a partir de metodologias ou de propostas de ensino diferenciadas. Nesse processo de ressignificação, ao lado de experiências de ensino relevantes

1 Doutor em Letras (UFPB), mestre em Linguagem e Ensino (UFCG), especialista em Literatura e Estudos Culturais e graduado em Letras (UEPB). Professor do Programa de PósGraduação em Formação de Professores e do Curso de Letras do Campus VI da Universidade Estadual da Paraíba, onde foi coordenador de área do PIBID-Língua Portuguesa. Desenvolve pesquisas voltadas para os seguintes temas: mulher e literatura, escritoras oitocentistas, literaturas não-canônicas, representações de gênero e de sexualidades, ensino de literatura, formação de leitores e formação de professores (marcelomedeiros_silva@yahoo.com.br). 
no processo de formação de professores, inclusive porque visibilizam sujeitos e temas marginalizados no contexto escolar, cumpre assinalar um diferencial deste volume: a inserção das tecnologias digitais como contraponto às práticas tradicionais de ensino e de formação docente e, consequentemente, como espaço que se sobressai no desenvolvimento de competências básicas, como falar, ouvir, ler e escrever, não só em língua materna como também em língua estrangeira/adicional, a partir de textualizações próprias ao espaço digital e a partir da valorização do protagonismo dos alunos.

Em Desenvolvendo a oralidade no ensino básico: o videocast em sala de aula, Geizille Nathália F. Athouguia e Luiz Francisco Dias, considerando a fragilidade como, nos moldes tradicionais, ocorre o ensino da oralidade e procurando interligar práticas de linguagem digitais com as já tradicionais práticas de linguagem desenvolvidas no interior da escola, voltam-se para o trabalho com a oralidade a partir da intermediação do vídeocast e mediante a ação de alunos em contextos reais de manifestação de práticas de oralidade. Já em $O$ uso das NTICS em sala de aula de língua inglesa: o caso do aplicativo de mensagem, via aparelho móvel celular, Ivandilson Costa centra-se em uma reflexão teórica acerca da relevância das NTICS no processo de ensino-aprendizagem de língua estrangeira, no caso o inglês, e apresenta uma proposta de ensino assentada no uso do aplicativo de mensagem WhatsApp. Mais do que reiterar a importância das NTICS para a melhoria da formação educacional dos alunos, o trabalho de Ivandilson Costa pontua a resistência dos docentes em ressignificar as suas práticas, incorporando a elas outras 
tecnologias que não as já tradicionalmente conhecidas e secularmente utilizadas.

A utilização de aplicativos também é o foco do trabalho de Iara Costa Nascimento e Simone Dália de Gusmão Aranha. Em Softwares Aplicativos como recursos didáticos: a inserção de tecnologias digitais no contexto escolas, a preocupação das autoras é com o desenvolvimento do letramento digital de alunos do ensino fundamental, visto que, em virtude de vivermos em uma cultura digital, a escola não pode se furtar de criar condições para que seus alunos se apropriem dos códigos e das ferramentas dessa cultura. Fechar os olhos para essa nova realidade é contribuir para que os alunos percam o seu endereço no tempo. Por isso, os letramentos digitais ganham relevo dentro do conjunto de ações educativas a serem promovidas pela escola que visam ao protagonismo de seus alunos. Pensando nesse protagonismo discente, é que, em Diário de Classe: estudo das postagens de uma aluna de escola pública no Facebook, escrito por Joana Rodrigues Moreira-Lima e Dánie Marcelo de Jesus, as autoras detêm-se na produção de posts de uma aluna em uma página do Facebook a fim de compreenderem, em meio ao discurso dessa aluna, as imagens que ela constrói acerca do espaço escolar e até que ponto ela se percebe como inserida em uma instituição que procura legitimar as estruturas hegemônicas de poder em que se assenta a nossa sociedade.

Em $O$ cinema como artefato semiótico mediador da compreensão e potencialização dos processos de ensino-aprendizagem, Fábio Marques de Souza procura descortinar as potencialidades pedagógicas que a sétima arte pode trazer para a formação de alunos e professores, notadamente no que diz respeito ao desenvolvimento e 
aprimoramento da competência intertextual. Para tanto, tendo em vista o fato de que o acesso a bens simbólicos deve ser um direito de toda/a cidadão/ã, o autor reitera a relevância da existência de cineclubes nas escolas a fim de não só atender às demandas educacionais propriamente ditas, mas também de contribuir para a formação humana dos sujeitos que integram a comunidade escolar. Ainda sobre a importância do audiovisual como recurso pedagógico para o exercício docente, Roseane Batista Feitosa Nicolau e Jeane dos Santos, em O Gênero curta metragem como objeto de ensino e aprendizagem da leitura $e$ da produção textual, preocupadas com o uso democrático das novas tecnologias e cientes de que cada vez mais a multimodalidade se faz presente em nosso cotidiano, por isso, apropriar-se de ferramentas multimodais torna-se um imperativo educacional, apresentam uma proposta de ensino cujo escopo é o desenvolvimento de práticas de leitura e de escrita assentadas na multimodalidade.

Como se pode depreender dos trabalhos anteriores, hodiernamente, os modos de comunicação são bem mais diversos que em outras épocas, mas, paradoxalmente, ainda convivemos com o dilema de haver ainda muitos sujeitos que sequer conseguem ler as mídias tradicionais. Em meio a esse descompasso, Anahy Zamblano defende, em Hipertexto: a força propulsora para o ensino de leitura e escrita na aula de língua portuguesa, que o conhecimento de linguagens múltiplas como forma de potencializar o desenvolvimento e a aprendizagem da leitura e da escrita de maneira que o sujeito possa utilizar essas ferramentas em esferas digitais ou não. A utilização do ambiente digital como recurso de ensino-aprendizagem é o foco da reflexão que Aline Tavares Costa e Filomena Maria 
Gonçalves da Silva Cordeiro Moita fazem em A interação em ambiente virtual de aprendizagem: um estudo de caso. Nesse trabalho, as autoras, tendo como escopo a interação em ambiente virtual de aprendizagem, a partir de um curso na modalidade b-learning, procuram investigar como, nos fóruns de que participam, professor-mediador e professores em formação continuada se valem da linguagem em ambiente digital de comunicação. Uma das conclusões a que chegam as autoras é que as práticas de linguagem empreendidas pelos sujeitos em ambientes digitais são teleguiadas pelos modos como esses mesmos sujeitos se valem da linguagem em ambientes não digitais de comunicação.

Partindo do pressuposto de que a interdisciplinaridade deve perpassar muitas das atividades realizadas no interior da escola e apresentando a publicidade como possibilidade para que a interdisciplinaridade funcione como recurso de aprendizagem, Lígia Beatriz Carvalho de Almeida, Roseane Andrelo e Mariana Pícaro Cerigatto, em Educomunicação no espaço da educação formal: atividades interdisciplinares, apresentam uma proposta de ensino que, unindo Língua Portuguesa, Geografia e Artes, procura orientar um trabalho com a temática da discriminação racial a partir de algumas peças publicitárias.

Considerando que a formação de professores parece ser o centro para o qual converge ou pelo qual tem de passar, necessariamente, boa parte das ações que visam à promoção de mudanças no nosso sistema de ensino, Antonio Roberto Faustino da Costa, José César dos Santos e Pedro Bergamo, em Formação de professores e práxis educativo-coletiva, amalgamando formação docente e práxis, ensejam uma formação assentada em uma perspectiva 
educativo-coletiva com vistas ao fomento de saberes propriamente educacionais que possam promover alterações significativas para os alunos que precisam romper com a mesmice escolar e assumir, assim, o protagonismo de sua formação. A formação docente continua sendo o escopo das reflexões de Arilane Florentino Félix de Azevêdo e Tânia Maria Augusto Pereira. Em O papel da formação de professores no combate ao sexismo em sala de aula na educação infantil, as autoras tecem uma reflexão acerca do sexismo a partir de ações e discursos gestados no interior da própria escola. Reconhecendo que a escola é uma instituição que fomenta desigualdades, produz diferenças e promove distinções, as estudiosas reiteram a importância de o espaço escolar ser também o lugar para a reflexão e para o combate das formas de discriminações. Para tanto, o/a professor/a que chega à escola deve, antes, ter recebido uma formação que tenha lhe permitido discutir e pensar as formas de preconceito (de gênero, de classe, de etnia, de origem) em nossa sociedade, o que exige uma mudança no currículo dos cursos de licenciatura que precisam ofertar componentes voltados para a discussão em torno dessas temáticas e, assim, entregar para o mercado de trabalho docentes mais conscientes da diversidade cultural e sexual que marca a nossa sociedade e aptos a trabalharem com tais temáticas, uma vez que tal diversidade se faz presente no interior das próprias escolas.

Foco das reflexões de muitos artigos presentes neste livro, o professor é o centro da discussão que Tatiana Dias Ferreira e Maria de Lourdes da Silva Leandro empreendem em O lugar da escrita no cotidiano do professor do ensino fundamental I: o que revelam os discursos. Por mais que vivamos em uma cultura digital, a escrita ainda 
permanece como eixo central das formas de comunicação em nossa sociedade, prefigurando, inclusive, modos de ser e de existir. Como as reflexões acerca da prática escolar de escrita apontam para o fato de que o seu exercício na escola é marcado por diferentes metodologias e perpassado por concepções várias acerca do ato de escrever, as autoras ensejam contribuir para essa discussão, procurando investigar quais as relações que docentes estabelecem com a escrita bem como as concepções que têm acerca do ato de escrever para compreenderem como isso determina o modo como esses mesmos docentes conduzem e orientam as propostas de escrita em sala de aula.

Porta de acesso aos bens culturais construídos ao longo da história da humanidade, a leitura é o centro da reflexão de Rosely de Oliveira Macário e Linduarte Pereira Rodrigues em A leitura na educação de jovens e adultos. Nesse artigo, os autores voltam-se para um conjunto de ações didáticas realizadas com alunos da educação de jovens e adultos com o intuito não só de desenvolver neles a competência leitora, mas também de, por meio do acesso a determinados impressos veiculados em revistas, despertar-lhes a consciência de estar no mundo, um mundo onde nem todos têm as mesmas oportunidades e, por isso, a educação se faz ainda necessária como prática de mudança social.

Como promovedora de mudanças social, a educação deve ser um processo de combate às formas de discriminação e de invisibilização. Nesse sentido, em consonância com o que dispõe a Lei 10.639/03, alterada pela Lei 11.645/08, que tornou obrigatório, na educação básica, o ensino da história e cultura afro-brasileira e africana em todas as escolas públicas e privadas, Marta Oliveira 
Barros e João Batista Gonçalves Bueno, partindo da constatação de que, embora a lei não seja desconhecida e se busque fazê-la cumprir, docentes ainda sentem dificuldades na elaboração de materiais didáticos acerca do que determina a referida lei. Essa dificuldade se acentua ainda mais quando o docente precisa abordar tal temática a partir de saberes locais. Por isso, em Memórias dos idosos quilombolas do Matão/PB: narrativas para o desenvolvimento de práticas de ensino, os autores defendem que uma alternativa pedagógica para abordagem da história e cultura afro-brasileira e africana é a valorização dos idosos e de suas memórias. Essas, quando objeto de estudo e de reflexão no interior da escola, podem contribuir para corroborar o sentimento de pertença dos alunos à sua comunidade de origem e consequentemente ressignificar as suas identidades.

Encerrando este volume, em Travessias e desafios da introdução dos estudos da língua portuguesa no Egito, Maged Talaat Mohamed Ahmed Elgebaly relata a experiência de criação do curso de Língua Portuguesa, na modalidade de bacharelado, no Egito. O autor volta-se, portanto, para os entraves que perpassam o ensino do Português como língua estrangeira, mas também não deixa de reiterar a importância de tal ensino no desenvolvimento da competência intercultural dos falantes que a procuram aprender.

No geral, o conjunto de artigos que compõem o presente livro, lembrando certas palavras de Antonio Nóvoa, comunga de uma perspectiva que advoga uma formação docente a partir de dentro. Isto é, reiteram o protagonismo dos próprios professores na formação de outros professores, uma vez que temos docentes universitários e docentes da rede básica como sujeitos da produção de saberes que 
cada um dos artigos apresentados registra. Nesse sentido, de forma central ou tangencial, a formação docente configura-se, aqui, como espaço de reflexão coletiva sobre a profissão docente e de mobilização de conhecimentos, vontades e competências a partir de sujeitos que conhecem por dentro aquilo de que estão falando ou ensinando.

Consequentemente, ainda pensando a partir de Antonio Nóvoa, considerando-se os sujeitos que escrevem este livro, temos em evidência a valorização de um conjunto de saberes que, por terem nascido da experiência, são/devem ser constantemente reelaborados porque se convertem em atividade/ação, mas também em reflexão sobre a própria experiência. Por fim, fruto de várias mãos, o livro que você, leitor, tem agora em suas mãos apresenta-nos uma outra lição: a de que o trabalho docente precisa deixar de ser solitário e ser solidário. Sem essa solidariedade, não é possível ter educação de qualidade, não se compartilham experiências. Sem a solidariedade entre os autores/as que o escreveram e os/as seus/ suas colaboradores/as, este livro seria apenas um sonho e não obra concreta a impulsionar outros sonhos e a gerar outras obras.

Julho de 2018. 



\title{
DESENVOLVENDO A ORALIDADE NO ENSINO BÁSICO: o vídeocast em sala de aula
}

\author{
Geizielle Nathália F. Athouguia ${ }^{1}$ \\ Luiz Francisco Dias ${ }^{2}$
}

\section{Considerações iniciais}

Um dos pontos fracos do ensino de língua materna é o desenvolvimento da modalidade oral no âmbito das atividades em sala de aula. Por sua vez, a escola se ressente também da distância entre as práticas de linguagem constituídas nos espaços digitais e as práticas de linguagem escolares, muitas vezes ainda permeadas pelos modelos textuais de pouco apelo entre os jovens. Por sua vez, os espaços digitais estão carregados de práticas de linguagem atraentes para os jovens. Trata-se de textualizações próprias do espaço digital. Dentre elas, encontra-se o videocast.

1 Mestre profissional em Letras (PROFLETRAS/UFMG). Professora de Língua Portuguesa do ensino básico da rede pública de Minas Gerais.

2 Doutor em Linguística pela UNICAMP. Professor titular da UFMG. Pesquisador do CNPQ. 
Neste texto, apresentamos um trabalho desenvolvido com vistas a produzir perspectivas de abordagem desse ponto franco no ensino. Trata-se da produção de videocast em sala de aula. Trabalhamos com a tese segundo a qual o desenvolvimento da oralidade pode ser incrementado pela prática de produção de videocasts pelos próprios alunos, em contexto de uso real. Além disso, ele pode ser um bom recurso para rever pronúncia e vocabulário, como também compreensão oral. Na mesma direção, a criação desses pequenos vídeos pode ser um excelente exercício para trabalhar pontos essenciais para a apreensão da competência oral, como ritmo, junção de palavras, entonação etc.

Uma das características modernas do vídeo se configura por ele ser composto por muitas linguagens. Esse caráter "multi" do vídeo vai ao encontro da proposta de "multiletramentos" de Rojo; Moura (2012). Por sua vez, Vargas et al. (2007, p.2) afirmam que "a produção de vídeos digitais pode ser utilizada como atividade de ensino e aprendizagem com vasto potencial educacional". Isso é devido à sua dinamicidade e comum associação com o entretenimento. Nesse sentido, fica nítido que a utilização do vídeo como fonte de ensino apresenta uma considerável possibilidade de motivação e envolvimento.

Os autores pontuam, ainda, a colaboração da produção de vídeos no desenvolvimento do pensamento crítico do aluno, além da promoção da expressão e da comunicação. O uso dos vídeos permite, também, propostas interdisciplinares, pois é inegável o caráter de integração de diferentes habilidades e capacidades do aluno, através desse recurso. 
No caso da presente pesquisa, os vídeos foram utilizados para abordagem de conteúdos específicos, a saber, resenhas de livros. Nesse aspecto, a relação entre o escrito e o oral está em foco.

O mundo virtual agrega rapidamente ao cotidiano, não apenas da comunidade escolar, mas da sociedade como um todo, tipos novos de textos, sejam orais ou escritos. Marcuschi (2002, p.13) afirma que "os gêneros textuais não são instrumentos estanques e enrijecedores da ação criativa dos usuários da língua". Dessa maneira, é preciso que os alunos estejam preparados para identificar, reconhecer e entender o funcionamento desses discursos, já que há uma conexão entre contexto social, cultural, tecnológico e virtual. Essa realidade, cada vez mais tecnológica e conectada, alterou significativamente o modo de produzir informações e, com isso, temos o constante surgimento de novos gêneros textuais, constituindo o que se denomina de "e-comunicação".

Partindo desse contexto, o uso didático do celular é uma alternativa pedagógica a ser considerada, de modo a buscar a união da facilidade que os discentes possuem no trato com essa mídia e toda a riqueza de gêneros que as redes sociais possuem, por exemplo. Ter a internet como aliada no processo ensino-aprendizagem em muito pode colaborar com o amadurecimento crítico dos alunos, pois sabemos que essas redes divulgam um grande número de gêneros e de informações, e o nosso público ainda não tem preparo o suficiente para se posicionar criticamente ante ao que é amplamente difundido nesses espaços. No contexto desta pesquisa, o YouTube serviu como ferramenta didática de suma importância, pois houve, nessa utilização dos vídeos nas aulas, a possibilidade de motivar os 
alunos a produzir outros materiais. Destaca-se, aqui, o quanto isso oportunizou o desenvolvimento da expressão dos alunos

Na realidade, a escola é um lugar propício a esse exercício, tendo em vista a possibilidade de se constituir nela um espaço de formação de opinião e conceitos por parte dos alunos. Atualmente, o que temos visto é uma visão de vilania do celular por parte dos professores, mais precisamente no que diz respeito à conexão com a internet, em relação à sala de aula. Isso é compreensível, pois os recursos de mídia são muito mais atrativos para os alunos, que passam a ver, cada vez mais, as aulas tradicionais como desinteressantes e enfadonhas, o que acarreta um conflito entre os professores e seu alunado, principalmente, o adolescente.

A tecnologia deve ser uma aliada da leitura e da escrita para que transformações possam ser alcançadas. $\mathrm{O}$ trabalho com os diversos gêneros deve estar ligado à intertextualidade e ao uso da tecnologia da informação e comunicação.

Com interesse em atribuir às aulas de português uma imagem mais envolvente e moderna, é preciso propor atividades capazes de colaborar com esse objetivo. Para tal, é necessário fazer uso de gêneros textuais tradicionais e a partir deles recriar textos com aspectos de novos gêneros, constituídos, é claro, em ambientes digitais.

No caso específico dessa pesquisa, trabalhamos um gênero tradicional como ponto de partida, que é a resenha, formulada em texto escrito. A partir de resenhas de obras da escritora Lygia Bojunga, os alunos elaboraram os pequenos vídeos a serem divulgados na rede digital. Essas considerações nos orientam a pensar o vídeo como 
uma significativa ferramenta em sala de aula, por ser uma inserção de novas tecnologias da informação e comunicação na escola e agregar novos modos de leitura e escrita. Dessa forma, acreditamos que refletir, organizar, propor e aplicar uma atividade de transposição de um texto escrito em vídeo pode significar uma rica atividade intertextual, em consonância com os postulados dos documentos regulatórios do ensino no País.

O principal objetivo dessa pesquisa consiste em buscar o desenvolvimento da oralidade por meio da produção de uma resenha, a qual será transposta para um gênero intermediário, que é o roteiro, que funcionará como uma ponte para a produção do vídeo, como produção final dos alunos participantes da pesquisa.

\section{Bases estruturais da pesquisa}

Tendo em vista a necessidade de promoção de um cenário que contemple a linguagem oral em situações formais de uso, é importante buscar gêneros formais que abordem um trabalho eficaz no desenvolvimento da oralidade. Nessa direção, a pesquisa utilizou o videocast (produção final).

De modo geral, os elementos composicionais de um texto recebem uma concepção estável e assimilável. As dificuldades surgem quando há a necessidade de mudança no formato no texto de origem, como por exemplo: livros que se tornam filmes, alguns gêneros que são transformados em ilustração, músicas etc. Esse movimento é chamado de transposição de gêneros ou retextualização.

Na retextualização, é preciso verificar as características de cada gênero e estabelecer entre eles uma comparação. 
Cabe identificar se há delimitações de um dos gêneros no processo de passagem para outro gênero. Para isso, é necessário também traçar estratégias para fazer a adaptação de um texto no outro, de modo a manter um paralelo no direcionamento dos sentidos nessa transposição.

Nesta pesquisa, buscamos ampliar a competência oral dos alunos, por meio da produção de vídeo, já que, através desse suporte, é possível verificar, analisar e traçar estratégias para trabalhar os meios linguísticos, visuais e sonoros da comunicação oral. Acreditamos que, após contato com os gêneros de trabalho, participarem de oficinas que abordam as suas características composicionais, os alunos poderão realizar a transposição da resenha para o vídeo, observando a manutenção do conteúdo temático do texto original.

Vimos no uso dos vídeos um interessante recurso para abordar não somente os aspectos linguísticos da modalidade oral, mas também traços paralinguísticos comuns às manifestações orais. Assim, não estaremos apenas voltados para o vocabulário ou organização da língua. Aqui entendemos como traços paralinguísticos as expressões faciais, tom de voz e gestos, e, nesta pesquisa, interessa-nos a averiguação e busca do desenvolvimento desses traços e da modalidade oral da língua como um todo nos alunos participantes da pesquisa.

Devido à propagação e à divulgação de materiais produzidos em vídeo, da consolidação do YouTube como principal site de hospedagem de vídeos, com a crescente visibilidade dos youtubers, o trabalho com esse conteúdo midiático torna-se cada vez mais produtivo. No entanto, os videocasts, muitas vezes, são considerados apenas como a transposição de outros gêneros para o suporte digital. 
Assim, selecionamos como ferramenta para trabalhar a oralidade a produção de videocasts, seguindo os padrões de Rojo; Moura (2012, p. 19) para incluir no texto linear a indicação de um texto veiculado em um suporte midiático.

Nessa direção, Rojo; Moura (2012) afirmam que a contemporaneidade tem possibilitado o surgimento de novos textos, os quais desafiam tanto a capacidade de leitura e compreensão, quanto à adequação deles às situações sociais de que participam.

$\mathrm{O}$ acesso facilitado às tecnologias tem favorecido a difusão de ideias e pensamentos por pessoas comuns, através do compartilhamento e distribuição de arquivos pela internet. O podcast é o arquivo de áudio gravado com vistas à sua divulgação, e o videocast, a mensagem em vídeo, também destinado à difusão. Por sua vez, o termo podcasting refere-se ao ato de difundir esses áudios e/ou vídeos pela internet. Já Broadcast é um termo do inglês, que traduzido significa difundir ou radiodifundir. Ele faz referência às transmissões, sejam estas de rádio, televisão e até mesmo de alto-falantes. Foi com o surgimento do aparelho da Apple, o iPod, que possui a função de tocar sons no formato $\mathrm{mp} 3$, que houve a junção das duas palavras, iPod com broadcast, nascendo, assim, o termo podcast. Na sequência, surgiu a opção de essas mensagens serem enviadas através de arquivos de vídeo (formato $\mathrm{mp} 4$ ), o que transformou o termo podcast em um termo novo, o videocast.

$\mathrm{O}$ videocast apresenta vários aspectos positivos. Um deles é a possibilidade de compartilhar mensagens diversas para amigos e parentes, informações para funcionários, aulas complementares para alunos etc. Ele se constitui de conteúdos audiovisuais, produzidos por 
blogueiros, internautas ou webmasters, e que são produzidos e publicados esporadicamente.

Por seu turno, a expressão vlog é a abreviação de videoblog (video + blog), que diz respeito a um tipo de blog em que os vídeos são os conteúdos predominantes. O que diferencia um blog de um vlog é justamente o formato da publicação. No caso dos blogs, os conteúdos são textos e imagens, já no caso do vlog, o conteúdo são vídeos. Podemos conceituar vlog, então, como um espaço de divulgação de vídeos. A produção e a publicação dos vídeos nos vlogs costumam ser periódicas.

O site mais utilizado pelos internautas para hospedar e compartilhar vídeos é o YouTube. Para que os vídeos sejam publicados por essa plataforma, é necessário que a pessoa crie um canal no site, que funcionará como um vlog para seus vídeos. O YouTube é o site eleito para abrigar os videocasts produzidos pelos alunos participantes dessa pesquisa, no entanto, existem outras inúmeras plataformas destinadas a este fim.

Nesse sentido, o YouTube vai além da possibilidade de comunicação entre as pessoas, já que pode ser utilizado, inclusive, como uma ferramenta no processo de desenvolvimento da oralidade, por proporcionar a percepção de características e marcas linguísticas. Importante considerar que essa plataforma apresenta, para tanto, uma rica variedade de textos reais pertencentes a diversos gêneros textuais, textos estes que podem ser selecionados, analisados e trabalhados em termos da oralidade.

A resenha é o gênero fundamental desta pesquisa. Motta-Roth e Hendges (2010) argumentam que à resenha compete fornecer uma opinião crítica sobre uma determinada obra, de modo que, tanto o "resenhador" - que 
descreve e avalia uma obra a partir do conhecimento adquirido ao longo da leitura - quanto o leitor têm objetivos conexos, uma vez que o autor da resenha fornece uma visão crítica e o leitor busca tal informação.

O modelo que utilizamos foi concebido por MottaRoth (1995) para o estudo de resenhas acadêmicas. No entanto, vimos nesse modelo a possibilidade de aplicação nesta pesquisa, uma vez que as resenhas produzidas pelos alunos, a grosso modo, seguem essa sistematização. Eis o modelo apresentado pela autora:

\section{APRESENTAR O LIVRO}

Passo 1: informar o tópico geral do livro; passo 2: definir o público-alvo; passo 3: dar referências sobre o autor; passo 4: fazer generalizações; passo 5: inserir o livro na disciplina.

\section{DESCREVER O LIVRO}

Passo 6: dar uma visão geral da organização do livro; passo 7: estabelecer o tópico de cada capítulo; passo 8: citar material extratextual.

3. AVALIAR PARTES DO LIVRO

Passo 9: realçar pontos específicos

4. (NÃO) RECOMENDAR O LIVRO

Passo 10a: desqualificar/recomendar o livro e/ ou; passo 10b: recomendar o livro apesar das falhas indicadas.

Fonte: Descrição esquemática das estratégias retóricas usadas no gênero resenha, segundo Motta-Roth (1995).

A transposição da resenha do escrito para o oral é considerada uma atividade textual, porque é verificado o funcionamento dos gêneros atendo-se ao seu propósito social, tema, estrutura composicional e o estilo comuns 
a eles. A transposição é considerada também uma atividade discursiva, pois acaba por envolver questões relativas à semântica e à pragmática associadas à língua. Nesse ponto, é fundamental pontuar que há entre os domínios linguísticos, textuais e discursivos uma inter-relação. A retextualização é definida por Marcuschi (2001, p. 46) como "um processo que envolve operações complexas que interferem tanto no código como no sentido."

\section{Aspectos metodológicos}

A pesquisa aqui em foco é do tipo qualitativa. Dentre as principais características desse tipo de pesquisa, Bogdan; Biklen (1994) e Lüdke; André (1986) destacam a configuração da fonte de dados, que é o ambiente natural, e sua ferramenta principal é o próprio pesquisador. Esse método enfatiza o contato direto do pesquisador com o ambiente e com a situação que está sendo investigada e o contexto no qual se apresenta, por meio do trabalho intensivo de campo.

O desenvolvimento da pesquisa se assemelha a um funil, pois, inicialmente, existem focos muito amplos; no entanto, ao final, essas questões se tornam mais específicas. Assim, o pesquisador vai delineando melhor esses focos no decorrer da pesquisa.

A presente investigação buscou analisar os resultados das produções dos alunos participantes em todas as oficinas de produção. De modo qualitativo, levantará os resultados relativos ao desenvolvimento ou não da habilidade oral desses alunos, principalmente, por meio da comparação da produção inicial e da final. 
Tomando por objetivo a realização de um produto, as fases e os procedimentos de uma pesquisa são compreendidos por etapas que são interligadas durante todo o processo, o qual é definido pelo objeto a ser pesquisado, pela opção metodológica adequada, pela coleta e análises dos dados coletados, dentre outros aspectos que podem ser descritos com base nas fases que o constituem.

A pesquisa foi orientada pelo seguinte percurso: (a) pesquisa bibliográfica e documental; (b) constituição do grupo focal; (c) aplicação do questionário; (d) oficina de contato com os gêneros; (e) oficina de vídeo - produção inicial; (f) oficinas de produção: (1)conhecendo videocasts, (2) produção de resenha, (3) motivação de leitura, (4) produção de roteiro, (5) expressão corporal, (6) interpretação vocal, (7) produção de vídeo, (8) trabalho com os vídeos dos alunos - produção final; (g) avaliação final - entrevista semiestruturada.

Os sujeitos da pesquisa foram constituídos por um grupo de alunos do sétimo ano do Ensino Fundamental de uma escola municipal de Belo Horizonte, da região de Venda Nova. As turmas do ano/série, geralmente, são compostas por cerca de 25 alunos, nessa instituição, perfazendo um total de 75 alunos, divididos em três turmas. Dado o foco da pesquisa, dispuseram-se a participar, inicialmente, 20 alunos desse total, com média de idade variando de 12 a 13 anos. A pesquisa trabalhou com dois grupos focais compostos por dez alunos cada.

A constituição de um grupo focal envolve uma técnica de pesquisa qualitativa em que a obtenção dos dados ocorre a partir de reuniões em grupo com pessoas que representam o objeto de estudo. De acordo com Gatti (2012), o grupo focal é uma técnica que permite fazer 
emergir uma multiplicidade de pontos de vista e processos emocionais, pelo próprio contexto de interação criado, permitindo a captação de significados que, com outros meios, poderiam ser difíceis de manifestar. Os participantes selecionados devem ter alguma vivência com o tema foco para que, dessa forma, a troca de informações seja produtiva.

$\mathrm{Na}$ apresentação da produção inicial, foram fornecidas informações sobre o gênero abordado, a quem a produção será voltada (público-alvo) e o formato que a produção deverá assumir. Os conteúdos dos textos que serão produzidos também constam na etapa de apresentação da situação.

A primeira produção serviu como um diagnóstico em que são observadas e traçadas as dificuldades dos alunos em relação à oralidade. Conforme propõem Schneuwly; Dolz (2004), após a apresentação da situação, o professor deverá solicitar a primeira produção que se refere ao momento em que os alunos irão produzir o primeiro texto, um videocast. Esse servirá de base para que tanto os alunos quanto a pesquisadora situem-se quanto às representações dessa atividade.

Orientando-se pela teoria acima explicitada, elaboramos um questionário que, de fato, buscasse colaborar com a coleta dos dados referentes aos conhecimentos prévios dos alunos acerca de videocasts, de resenhas literárias, da autora Lygia Bojunga, escritora das obras que serão resenhadas pelos alunos no decorrer dessa pesquisa para criação do vídeo final, dos canais do Youtube e Booktubers.

De acordo com Schneuwly; Dolz (2004), é a produção inicial que fornece elementos para o desenvolvimento das próximas fases da sequência didática. Ela possibilita ao 
professor, através de sua observação, indicar o que deverá modular e as adaptações que se fazem necessárias, considerando as necessidades dos alunos.

\section{O videocast: processo de construção}

Descreveremos a seguir as principais oficinas realizadas, e que se constituem como partes essenciais do processo de produção dos videocasts.

Oficina "conhecendo os gêneros"

Esta oficina consistiu em colocar os alunos participantes em contato com os gêneros abordados nesta pesquisa. Nessa direção, os alunos do grupo focal foram encaminhados para o laboratório de informática da escola locus. Lá, foram orientados a entrar no site YouTube, acessar o canal "Mundo Paralelo" e "Chiclete Violeta". Esses são canais de booktubers que, com determinada frequência, apresentam vídeos com resenhas de livros, visando a motivação da leitura por parte dos seguidores e interessados de modo geral. Além das resenhas, esses canais abordam, também, temas comportamentais direcionados aos públicos adolescente e jovem e, ainda, temas relacionados aos estudos, trazendo vídeos com dicas e métodos que facilitam e orientam uma rotina de estudos mais prática e eficaz.

Nesta oficina, os 10 alunos permaneceram no laboratório em torno de uma hora e trinta minutos, onde foram orientados pela pesquisadora e pela funcionária responsável pelo laboratório de informática a acessar o site a 
digitar na janela de busca o nome de um dos canais citados acima e assistir a alguns vídeos. Os alunos, de forma livre, selecionaram as resenhas e as assistiram, com auxílio de fones de ouvido. Outra orientação repassada dizia respeito à atenção que os alunos deveriam ter não apenas às resenhas assistidas, mas também à linguagem utilizada pelos booktubers.

Após esse momento, os alunos foram encaminhados para a sala de aula e, de forma mais informal e descontraída, puderam expor suas visões e opiniões acerca dos vídeos assistidos e ouvidos, como é o caso da aluna portadora de deficiência visual. As observações foram feitas seguindo direcionamentos prévios da pesquisadora, mas houve, durante toda a conversa, a liberdade para que eles pudessem expor o que perceberam, tanto para a professora, quanto para os demais colegas.

Buscando levantar as informações que os alunos possuíam a respeito desse gênero textual, foi proposto aos alunos que produzissem um vídeo com uma resenha. Não foi exigido que o objeto resenhado fosse um livro, sendo dada, mais uma vez, a liberdade de escolha para os alunos. Houve, por parte da pesquisadora, a sugestão para que os alunos resenhassem livros, filmes, músicas ou séries.

O vídeo foi filmado pela professora pesquisadora, em sala de aula, individualmente. Anterior a esse momento, foi realizada uma conversa coletiva, na qual todos os alunos se manifestaram a respeito do objeto que seria resenhado. Nesse ponto, foi notado algo que nos chamou a atenção: o fato de que apenas as meninas optaram por resenhar livros, com exceção de uma que decidiu por uma série. Os meninos, em sua totalidade, elegeram filmes. 
Essa seleção tão distinta entre os gêneros feminino e masculino chamou a atenção de tal forma que houve a necessidade de uma intervenção, por parte da pesquisadora. Os alunos, então, foram questionados quanto à sua escolha. Cabe ressaltar que esse questionamento não teve caráter crítico; a intenção era apenas a de compreender a motivação de cada escolha.

Oficina de motivação de leitura

Este foi o momento em que houve a apresentação dos livros escolhidos para serem resenhados pelos alunos, todos eles da escritora gaúcha Lygia Bojunga: A Bolsa Amarela (2000); O sofá Estampado (1985); Tchau (1997); Livro, um encontro (1988); Retratos de Carolina (2002) e $O$ Meu Amigo Pintor (1981). Os dois grupos focais tiveram acesso a essas seis obras e após a apresentação de cada uma delas, por parte da pesquisadora, eles fizeram a escolha do título que seria lido e depois resenhado.

Como forma de motivar os participantes a ler, foi importante um ambiente favorável para a apresentação tanto da autora como de sua obra. Para isso, essa oficina foi realizada na Biblioteca da escola locus dessa pesquisa e ministrada pela bibliotecária da escola juntamente com a pesquisadora.

Inicialmente, foi realizada pelas ministrantes da oficina a leitura do capítulo inicial de cada obra. Tendo por fundamento práticas realizadas em salas de aula, no decorrer da nossa carreira docente, vemos, nessa leitura de introdução à obra, uma espécie de "aperitivo" capaz de despertar nos alunos a vontade de conhecer a obra como um todo, motivando-os a realizar a leitura necessária 
para o prosseguimento dessa pesquisa. Trata-se de um momento de degustação, onde há a realização de leituras em voz alta e com entonação adequada, de trechos da obra, visando aguçar a curiosidade dos alunos em torno do livro que a ser lido.

\section{Oficina de produção de roteiro}

Esse é momento da escrita do roteiro do vídeo. Caber frisar que o videocast possui a capacidade de abordar textos com estruturas dinâmicas e ágeis. Considerando isso, cada grupo iniciou a organização de suas exposições, sempre se pautando pela estrutura e pelos elementos do produto em questão: o videocast.

De acordo com o dicionário de comunicação, o roteiro é "o texto que indica previamente o desenvolvimento de um programa de rádio ou de TV." (RABAÇA; BARBOSA, 2001, p. 651). Além disso, os autores indicam a apreensão do conceito de script, qual seja: "texto dos diálogos das narrativas e das indicações cênicas (rubricas) de programas de televisão ou rádio, filmes ou espetáculos teatrais. (RABAÇA; BARBOSA: 2001, p. 661). Foi possível extender esse conceito para o contexto dessa pesquisa. Assim, podemos afirmar que também para se produzir um vídeo é necessário que seja elaborado um roteiro que indique os pontos e o percurso por meio do qual a apresentação deverá se orientar.

Essa oficina foi ministrada pela pesquisadora e abordou pontos referentes à estrutura do gênero roteiro e alguns itens que dizem respeito ao conteúdo desse gênero, como, por exemplo: O que será apresentado? Qual o tempo de 
apresentação? Qual meu público? Qual meu objetivo com essa apresentação?

\section{Oficina de expressão corporal}

Partimos do pressuposto de que a oralidade contempla operações linguísticas complexas, como gestos, entonação, postura e expressões faciais. E tendo em vista que, na produção dos videocasts, os alunos se utilizam de todos esses recursos extralinguísticos, apreendemos a necessidade de que uma das oficinas de produção fosse voltada para a expressão corporal.

Essa oficina foi ministrada por uma profissional da área de locução e foi acompanhada pela pesquisadora. Nela, foram abordados os pontos mais importantes de uma apresentação oral, tais como: script, voz, vocabulário, expressão corporal, seleção, naturalidade, emoção e conhecimento. Cada um dos itens foi tratado pela profissional, que utilizou de uma linguagem bem acessível para alcançar os participantes.

No que diz respeito à locução, foram realizados exercícios, em dupla, nos quais os alunos precisavam realizar a leitura de sequências de palavras que possuíam os mesmos dígrafos ou terminações ou encontros vocálicos. Cada dupla recebeu uma lista, os alunos fizeram a leitura em voz baixa, entre eles; em seguida, se apresentaram para os presentes. Sob a supervisão da profissional, os alunos realizaram a leitura dos blocos de palavras, pautando-se pelas indicações feitas pela ministrante. As orientações dela baseavam-se, principalmente, no tom de voz ideal, na velocidade da fala, na postura e na gesticulação. Em todo o tempo, ela reforçou a necessidade de haver limpidez na 
fala, visando o maior e melhor entendimento do público, explicando que uma fala acelerada é pouco compreendida, e que o contrário torna a apresentação cansativa.

Em diversas etapas da aplicação dessa pesquisa, foi trabalhada com os participantes a necessidade de se haver uma preparação prévia à apresentação oral. Por isso, a proposta de uma oficina voltada ao planejamento do que seria apresentado. Essa oficina foi ministrada pela pesquisadora. Nela, foi abordado o conceito do gênero roteiro e todas as suas características.

\section{Oficina de interpretação vocal}

É de suma importância que os professores exponham seus alunos às mais diversas situações de uso da modalidade oral da língua. Marcuschi (2003, p. 14) afirma que "a conversação é a primeira das formas de linguagem a que estamos expostos e provavelmente a única da qual nunca abdicamos pela vida afora.". A linguagem oral abarca diversos recursos linguísticos e expressivos.

Buscando o desenvolvimento de alguns desses recursos, a realização dessa oficina se mostrou necessária para que os participantes alcançassem um nível de oralidade o mais claro possível, considerando, obviamente, o nível apontado na produção inicial de cada um. A oficina teve por objetivo um melhor aproveitamento da entonação vocal, a observação da necessidade das pausas corretas, o uso ou eliminação de algumas expressões, formas de evitar certos tiques orais etc.

Essa oficina foi ministrada por uma locutora de rádio e também aconteceu na escola locus dessa pesquisa. 
Oficina de produção de vídeo

Como parte dessa oficina, foi realizada uma visita dos participantes a uma escola de Youtubers, em Belo Horizonte, onde se ensina a desenvolver o processo criativo e são fornecidas informações a respeito de como abrir um canal no YouTube, por exemplo.

Vale ressaltar que, nessa etapa, foi importante que os programas de edição utilizados na realização dos videocasts já tivessem sido pesquisados e que os alunos já tivessem contato com alguns canais dos chamados "Booktubers". Esse termo faz referência às pessoas que se dedicam a fazer resenhas de livros impressos, em vídeos e as disponibiliza na internet.

É aqui que demos início aos ensaios das gravações da produção final, com apoio de celulares e tablets. Intencionalmente, a pesquisadora permitiu que os estudantes observassem que algumas das passagens do roteiro não faziam parte da dinâmica do videocast. Essas observações, feitas por eles mesmos, os fizeram perceber a necessidade de readequação do texto e refacção desses textos escritos.

Como essa etapa envolvia as gravações, todo o equipamento necessário para que os alunos pudessem trabalhar estava ao alcance deles. Porém, foi essencial estipular o tempo máximo de cada gravação, já que videocasts são vídeos curtos.

Após a gravação dos vídeos, a pesquisadora fez a análise e a seleção do material produzido. Depois da seleção dos vídeos, foi o momento de partir para as oficinas de edição. Nessas oficinas, tivemos o apoio do agente de informática da escola locus da pesquisa. Contudo, vale 
enfatizar que o trabalho foi realizado pelos próprios alunos, uma vez que vimos nessa pesquisa uma possibilidade de abordagem do letramento digital.

Trabalho com os vídeos dos alunos - produção final

Seguindo os pressupostos de Schneuwly; Dolz (2004), e finalizados todos os módulos da sequência didática abordados aqui como oficinas de produção, pudemos entender que o aluno teve a possibilidade de colocar em prática as noções e os instrumentos elaborados separadamente nos módulos. Essa produção permitiu, ainda, que a pesquisadora realizasse uma avaliação somativa. Nessa etapa, foi possível, e era esperado, que houvesse o investimento das aprendizagens. Para tanto, sugerimos que o professor, nesse momento, retome com os alunos os objetivos a serem atingidos com essa produção e ofereça a eles um controle sobre seu próprio processo de aprendizagem.

Após a produção dos vídeos, a pesquisadora fez a seleção e a análise do material produzido. Uma vez concluído esse trabalho, partimos para a abertura do canal do YouTube que hospedou os videocasts de resenhas literárias produzidas pelos alunos. Posteriormente, o canal foi divulgado ao conjunto maior de alunos e a toda a comunidade escolar, a fim de promover uma ação multiplicadora e motivadora. 


\section{A produção do videocast na escola: avaliando os resultados}

Para que a produção final tivesse um resultado de qualidade, foi importante fazer uma análise do conteúdo e dar novas orientações à turma ao fim de cada uma das etapas, lembrando que a avaliação deve estar presente em todas as oficinas de produção no decorrer da pesquisa. Para isso, a pesquisadora avaliava o material coletado e fazia a seleção de informações, além de pedir a readequação e refacção das mesmas para os alunos, se fosse o caso. As ações que percorreram essa etapa foram: leitura, reflexão com a turma acerca dos roteiros elaborados, além da observação das propostas no que se refere ao atendimento ao formato escolhido. A análise das conclusões dos estudantes sobre os trechos que precisaram ser adaptados, diferenciando, assim, texto oral e texto escrito, fizeram, também, parte da avaliação.

Como avaliação final, a pesquisadora utilizou a entrevista semiestruturada. A entrevista pode ser um rico meio de comunicação. Ela representa um instrumento básico para esse tipo de pesquisa. A entrevista consiste, basicamente, em uma conversa a dois, feita por iniciativa do entrevistador/pesquisador e é destinada a fornecer informações pertinentes para objeto de pesquisa, nesse caso, para avaliação dos resultados; ou seja, intencionalmente o pesquisador recolhe informações através da fala dos sujeitos. (LUDKE; ANDRÉ, 1986).

Inicialmente, notamos certa familiaridade dos alunos com gêneros da categoria oral, já que todos se mostraram cientes do que deveriam fazer, seja considerando 
as apresentações orais escolares ou pautando-se pelos vídeos dos booktubers assistidos na oficina "Conhecendo os gêneros".

Obviamente que fatores como timidez e insegurança foram facilmente observados, tanto na gravação do vídeo de cada um dos alunos, quanto na análise desses pela pesquisadora. A maioria dos alunos mostrou certo desconcerto ao se verem diante da câmera. No entanto, um deles teve, nitidamente, uma dificuldade muito maior em relação aos demais.

Essa fase foi de suma importância para verificar qual estava sendo a postura dos participantes diante da leitura. O processo dessa fase da oficina foi realizado através de perguntas sobre as obras direcionadas aos alunos. Como uma mesma obra foi lida por participantes diferentes, as impressões e pontos de vista dos alunos foram bastante distintos. Possivelmente essa ocorrência se deva aos conhecimentos prévios e experiências de cada um. Aproveitando a exposição de cada aluno a respeito do livro, a pesquisadora passou a mediar uma discussão entre os leitores da mesma obra com a intenção de favorecer a troca de informações, visões, conclusões acerca do livro, entre eles. Um ponto negativo dessa fase foi o fato de cinco alunos não terem avançado muito na leitura, $\mathrm{o}$ que fez com as discussões não os contemplasse de modo tão significativo.

O segundo encontro para tratar das atividades da etapa durante a leitura foi ainda mais produtiva, já que apenas dois alunos não haviam concluído a leitura, e todos os demais já chegaram expondo suas opiniões sobre as obras. Com toda a história em mente, eles tiveram mais firmeza e segurança para apresentar suas conclusões de 
leitura. Boa parte dos alunos se manifestou favorável às histórias, o que indica, ao menos aparentemente, que as obras agradaram aos alunos, salvo três deles, sendo dois que afirmaram não terem gostado e um que alegou ter gostado em partes. Aos alunos que não haviam finalizado a leitura, foi estipulado novo prazo, que foi cumprido.

As exposições dos alunos nas duas fases "durante a leitura" nos mostraram que houve mudança no modo como eles encararam o ato de ler propriamente dito e como viram as obras em si, uma vez que fizeram observações bem além do esperado. Esse encontro que havia sido, a priori, planejado para abranger algumas atividades da etapa "durante a leitura", por fim, acabou assumindo algumas atividades da etapa "depois da leitura", já que a maioria dos alunos já tinha finalizado a tarefa. As atividades desenvolvidas nessa fase foram a construção da síntese semântica do texto, a troca de impressões a respeito do texto lido e a avaliação crítica do texto.

Quanto à resenha, na produção inicial, foi observado que parte dos alunos não cumpriram um requisito básico do gênero, ou seja, não realizaram uma crítica ao objeto resenhado, o que não ocorreu na resenha apresentada no videocast final. Todos os alunos, sem exceção, expuseram seu ponto de vista a respeito do livro lido, sendo que grande parte deles optou por colocar sua opinião ao final da apresentação das partes principais do enredo.

No que se refere ao videocast, a postura dos participantes nesse item também foi um ponto de evolução, no entanto, em menor escala. De modo geral, houve melhora, mas ainda foi possível observar menos desenvoltura, diante da câmera, em pelo menos metade dos alunos. Obviamente, consideramos que essa necessidade 
de desenvoltura ante à câmera, tendo em mente a necessidade de adaptação ao local de circulação, o público-alvo e os objetivos do vídeo, trouxe uma dificuldade maior para os alunos.

Com relação à oralidade, foi possível observar melhora em muitos aspectos e na maioria dos alunos. É importante relembrar que os "aspectos extralinguísticos" foram traçados considerando uma situação comunicativa realizada pessoalmente, no entanto, entendemos que serve de parâmetro de análise na produção realizada no decorrer da aplicação dessa pesquisa. Um ponto essencial nessa análise foi o método utilizado: consideramos a avaliação do aluno em relação a ele mesmo, ou seja, nossa avaliação foi pautada na comparação da produção final com a inicial de cada aluno.

\section{Considerações finais}

Através dessa pesquisa, percebemos o valor social das interações orais, considerando os avanços comunicativos dos participantes da fase de aplicação. Reiteramos a necessidade de mudanças nas metodologias de ensino utilizadas pelas instituições escolares, no sentido de assumir e sistematizar o ensino com práticas que busquem o desenvolvimento da competência comunicativa oral.

Observamos que, ao transpor suas resenhas para videocast, os alunos aprendem não só o conteúdo, mas também são direcionados rumo a uma maior autonomia e segurança na produção textual. $\mathrm{O}$ que temos aqui é uma oportunidade de agregar as tecnologias atuais à prática docente. 
O ato de discursar/falar em público ou diante de uma câmera apresentou um desafio por colocar os sujeitos em evidência. Uma das metas dessa pesquisa foi a de buscar a capacidade de superação desse desafio por parte dos participantes. Outro ponto significativo desse trabalho foi seu fim multiplicador, ou seja, através dos videocasts com resenha, é possível despertar o desejo de outras pessoas lerem livros ou de também produzirem seus textos. Por isso, percebemos que é necessário realizar uma reflexão a respeito de possíveis formas de operacionalizar a abordagem da modalidade oral da língua, a qual compôs o eixo norteador dessa pesquisa.

Observamos que a prática da oralidade na sala de aula capacita os alunos a assumir um papel mais ativo e mais protagonista no processo de ensino/aprendizagem, tornando-os verdadeiros agentes na construção do seu próprio conhecimento, resultando, também, no desenvolvimento da sua visão crítica. Nesse sentido, não é mais possível abrir mão de reservar para garantir à modalidade oral seu lugar nas aulas de língua portuguesa (e não só delas), com vistas a preparar os alunos para diversas situações comunicativas.

Na busca por tornar o processo de ensino de linguagem mais atraente e significativa, é essencial pensar em propostas didáticas que aproximem o aluno de sua realidade, que sejam adaptadas às exigências dessa nossa sociedade cada vez mais conectada. Há uma clara possibilidade de tornar as aulas de português cada vez mais plurais e interdisciplinares lançando mão de novas tecnologias. 


\section{Bibliografia}

BOGDAN, R. C.; BIKLEN, S. K. Investigação qualitativa em educação. Porto: Porto Editora, 1994.

GATTI, B. Grupo focal na pesquisa em ciências sociais e humanas. Brasília: Líber Livro, 2012.

LÜDKE, M.; ANDRÉ, M. E. D. A. Pesquisa em educação: abordagens qualitativas. São Paulo: EPU, 1986.

MARCUSCHI, L. A. Da fala para a escrita: Atividades de retextualização. São Paulo: Cortez, 2001.

. Gêneros textuais: definição e funcionalidade. In: A.P. DIONÍSIO; A.R. MACHADO; M.A. BEZERRA (eds.). Gêneros textuais e ensino. Rio de Janeiro, Lucerna, 2002.

Análise da conversação. 5.ed. São Paulo: Ática, 2003.

MOTTA-ROTH, D. Rhetorical features and disciplinary cultures: a genre- based study of academic book reviews in linguistics, chemistry and economics. 1995. Tese (Doutorado em Linguística) - Universidade Federal de Santa Catarina, Florianópolis, 1995.

MOTTA-ROTH, D.; HENDGES, G. R. Produção textual na Universidade. São Paulo: Parábola, 2010.

RABAÇA, C. A.; BARBOSA, G. G. Dicionário de Comunicação. Rio de Janeiro. Campus, 2001.

ROJO, R; MOURA, E. Multiletramentos na escola. São Paulo, Parábola Editorial, 2012. 
SCHNEUWLY, B.; DOLZ, J. Gêneros orais e escritos na escola. Campinas: Mercado de Letras, 2004.

VARGAS et al. Promídia: produção de vídeos digitais no contexto educacional. Instituto de Computação Universidade Estadual de Campinas, Campinas - SP, 2007. Disponível em: <http://www.cinted.ufrgs.br/ ciclo10/artigos/1bAriel.pdf>. Acesso em: 13 set. 2017. 



\title{
O USO DAS NTICs EM SALA DE AULA DE LÍNGUA INGLESA: o caso do aplicativo de mensagem, via aparelho móvel celular
}

\author{
Jordânia Virgínio dos Santos ${ }^{1}$ \\ Ivandilson Costa ${ }^{2}$
}

\section{Introdução}

Historicamente observamos que o mundo desde sua pré-história vem sendo modificado pelo surgimento de novas tecnologias, passando pelas mais simples até as formas de comunicação mais avançadas que temos nos dias de hoje. Junto com esses grandes avanços tecnológicos vem crescendo também o conhecimento humano, fazendo assim uma certa exigência da incorporação dessas tecnologias no ambiente de ensino.

Vivemos em um mundo onde o desenvolvimento tecnológico e a utilização das novas tecnologias da informação e comunicação (NTICs), vêm crescendo cada vez mais. Atualmente se pararmos para observar em uma sala de aula, perceberemos que a maioria dos alunos tem um

1 Graduada em Letras/Língua Inglesa pela Universidade do Estado do Rio Grande do Norte (UERN), Núcleo Avançado de Ensino Superior de Macau (NAESM).

2 Doutor em Letras/Linguística pela UFPE. Professor Adjunto da UERN, Departamento de Letras Estrangeiras. 
aparelho móvel celular e, partindo desse contexto, muitos educadores tiveram que fazer uma revisão nas suas formas de ensinar, pois, como as NTICs já estão automaticamente inseridas no nosso cotidiano, esses professores precisam estar preparados para inseri-las em sua sala de aula, adequando-se à realidade em que esses alunos se encontram e também passar a enxergar as NTICs como um aliado para facilitar ainda mais o aprendizado. Não obstante, nota-se que mesmo já fazendo parte do nosso cotidiano ainda existe uma certa rejeição por parte de alguns professores.

Partindo desse ponto, buscamos tratar de um tipo específico de mídia social, o uso do aplicativo de troca de mensagens por aparelho móvel, WhatsApp Messenger, como um aliado para o ensino de língua inglesa. Mostraremos, através de um diagnóstico, como elas podem ajudar a melhorar o conhecimento de professores e alunos nesse campo de aprendizagem e, por consequência, apresentaremos um quadro sugestivo, demonstrando de que forma o aplicativo WhatsApp poderia ajudá-los.

Nessa perspectiva, a escolha por tal aplicativo se justifica, principalmente pelo fato de que a maioria dos alunos hoje faz uso do WhatsApp, para diversas atividades, como por exemplo: tirar e compartilhar fotos, gravar, enviar e escutar/ver áudios e vídeos, usar do sistema de messenger (bate-papo). Além disso, percebemos que, como é ainda comum em muitas escolas públicas e de regiões de base mais rural, como é o caso da localidade foco de nossa investigação, a cidade de Pendências (RN), existe ainda uma certa carência em se tratando da aplicação de novas tecnologias no ensino de língua inglesa. É, portanto, pretensão de nossa pesquisa fornecer bases para 
subsidiar professores, quanto ao emprego de NTICs como um aliado ao processo de ensino-aprendizagem, especialmente de língua inglesa.

Diante desse quadro, cumprindo um objetivo principal do trabalho, foi feito um diagnóstico de como se encontram os estudos atualmente sobre as NTICs e sua relação com o ensino de Língua Inglesa, para, a partir disso, apresentarmos um quadro panorâmico de como pode ser utilizado em sala de aula. Elaboramos, nesse sentido, um apanhado teórico de como vem sendo tratado o uso das NTICs aplicáveis a aulas de língua inglesa, bem como fornecemos subsídios para a construção de procedimentos para trabalhar com o aplicativo de troca de mensagens em aulas de língua inglesa. Construímos, ainda, procedimentos de trabalho com o aplicativo, com o cuidado de que seja adequado a turmas de língua inglesa do ensino fundamental II, foco da pesquisa.

O trabalho se enquadra no âmbito de uma pesquisa bibliográfica, pois buscamos mostrar, através de investigações já realizadas, como o uso das NTICs pode ajudar a melhorar o ensino aprendizagem de língua estrangeira. Trata-se, desse modo, de pesquisa "desenvolvida a partir de material já elaborado, constituído principalmente de livros e artigos científicos" (GIL, 2008, p. 32).

A proposta se desenvolveu, portanto, pelo levantamento em bibliografia especializada, de sugestões e métodos de utilização de NTICs no ensino de língua inglesa, delimitando-se em um apanhado de trabalhos já publicados em literatura especializada, periódicos inclusive, em plataformas digitais inclusive, sobre o tema específico do uso de aplicativos de troca de mensagem para celular e seu uso no ensino de língua inglesa. 
Posteriormente, foi elaborada uma proposta de trabalho em sala de aula para o público do ensino fundamental, a partir da construção de quadros sob o formato de sequências didáticas, para o fim específico de se tratar dos seguintes pontos especialmente: ensino da compreensão oral, ensino da escrita e ensino do vocabulário. As sequências didáticas são compostas dos seguintes componentes: conteúdo; dados da aula (o que o aluno pode aprender, duração das atividades, conhecimentos prévios); estratégias e recursos; recursos complementares; avaliação.

\section{Ensino de Inglês e tecnologias: o uso de aplicativos como um instrumental didático}

Ensino de Lingua Estrangeira (LE)

e ensino de Lingua Inglesa (LI)

$\mathrm{O}$ ensino de língua estrangeira, principalmente o da língua inglesa, passou por várias mudanças desde as últimas décadas. Foram criados métodos e abordagens, e, quando se fala em ensino de LE, é preciso conhecer os principais métodos, que são: Método Tradicional (ou método da gramática-tradução), Método Direto, Método Audiolingual e a Abordagem Comunicativa.

Segundo Leffa (1988), a abordagem da gramática e da tradução (AGT) é conhecida também como método, tendo sido a metodologia com mais tempo de uso na história de ensino de línguas, ainda hoje utilizada. Ela consiste no ensino da segunda língua pela primeira e toda informação é dada através de explicações na língua materna do aluno. Aquele autor ainda cita três passos essenciais para aprendizagem da língua, que são: “(a) memorização prévia de 
uma lista de palavras, (b) conhecimento das regras necessárias para juntar essas palavras em frase e (c) exercícios de tradução e versão (tema)" (LEFFA, 1988, p.34).

No método direto acontece o contrário da AGT, pois o aluno deve aprender a L2 pela L2 e a língua materna nunca deve ser utilizada na sala de aula. Os significados se dão através de gestos e gravuras, em que não se pode recorrer ao método da tradução. Já o método audiolingual tem objetivo de levar o aprendiz a comunicar-se na língua-alvo através da formação de novos hábitos linguísticos. A abordagem comunicativa, por seu lado, caracteriza-se por ter o foco no sentido, no significado e na interação entres os aprendizes de uma nova língua.

Já Oliveira (2014) elabora grandes questões teóricas para o ensino do Inglês, para o que destaca o conceito de método. Nesse âmbito, aborda, além dos aqui levantados, ainda os métodos como a abordagem oral, o método audiolingual, os métodos alternativos (Silent Way, Suggestopedia, Total Physical Response-TPR, Community Language Learning- CLL) e os métodos comunicativos (abordagem natural, abordagem comunicativa, abordagem baseada em tarefas, abordagem intercultural).

Mais posteriormente, aquele autor (OLIVEIRA, 2015) destaca como um grande desafio no campo do ensino de LI: o desenvolvimento da habilidade oral na segunda língua. Ele considera que a compreensão oral é a habilidade que mais desafios apresenta para os aprendizes brasileiros. Remonta, assim, às atividades de pré-compreensão, contemplando quatro micro-habilidades: a busca por informações específicas, o reconhecimento de palavras, a busca por ideias gerais e a inferenciação. E prossegue ressaltando a importância de uma questão premente nos 
tempos de hoje: o uso dos recursos tecnológicos no ensino da compreensão oral.

Segundo Donnini, Platero e Weigel (2010, p.15), a concepção de língua como sistema e estrutura se faz presente no ensino de línguas estrangeiras de modo bastante significativo e que a abordagem oral ou situacional (The Oral Approach ou Situational Language Teaching) foi uma das primeiras metodologias concebidas. Essa metodologia está fundamentada em três pilares: o uso de vocabulário, o controle de estruturas gramaticais e a apresentação de ambos em situações, como, por exemplo, uso de objetos concretos ou representações gráficas que venham possibilitar a associação direta entre o conteúdo e seu significado.

Já o método audiolingual, conhecido também como audiovisual, ainda segundo Donnini, Platero e Weigel (2010 p.16), "incorporou a ênfase na estrutura linguística presente desde o método direto (ou método de Berlitz)". As autoras dizem que esse foi um evento marcante na história do ensino de línguas, pois foi o primeiro a ganhar o status de método cientifico e que os seus procedimentos estariam todos fundamentados, testados e comprovados por linguistas e psicólogos.

Com os métodos situacional e audiovisual, surgiram várias outras manifestações de métodos alternativos, como, por exemplo, sugestologia (suggestopedia), o ensino silencioso (silent way), a resposta física total (TPRtotal physical response), o ensino comunitário (community language teaching), entre outros. Para Donnini, Platero e Weigel (2010 p.17), esses métodos:

Constituíram ensaios de respostas à concepção de aprendizagem comportamentalista, sem, no entanto, 
encontrarem muita adesão entre os professores, quando comparados à força adquirida pelos métodos audiovisual e situacional.

Posteriormente, as autoras falam sobre o surgimento do método comunicativo no ensino de línguas. O objetivo desse método é desenvolver a proficiência comunicativa, tendo foco no sentido, ou seja, no significado, na interação entre os falantes. Como exemplo, em uma aula onde esse método está presente, o professor age como coordenador e facilitador, fornece materiais e situações para que o aluno possa ter uma aprendizagem real.

Além disso, as quatros habilidades (ouvir, falar, ler e escrever) estão imbricadas na manifestação da competência comunicativa e em contextos de seu uso real, pois muitas vezes vivenciamos situações em que precisamos fazer utilização de mais de uma dessas habilidades ao mesmo tempo.

Portanto, para que todos esses métodos citados anteriormente cheguem até a sala de aula, eles necessitam do professor e não podemos deixar de falar no seu papel que é de grande importância, pois é através dele que os alunos vão se apropriar dos saberes escolares e se tornarem críticos e autônomos. Segundo Gandour (2014, p.157):

Os professores, sendo os maiores conhecedores das necessidades sociais e educacionais dos alunos, devem contribuir e participar de forma mais efetiva nos diversos eventos que compõem o processo pedagógico. 
Daí a importância de ser um professor reflexivo, ou seja, professor que reflete sobre sua prática de ensino, com o intuito de modificá-la, melhorando não só para benefício próprio, mas para todos aqueles que fazem parte da comunidade escolar. Ser um professor reflexivo não é só transmitir conteúdo, é atuar na interação com os alunos e toda a comunidade, é ser responsável por aquilo que acredita ser o certo, adequando-se à realidade, ao levar essa teoria para a sala de aula, visando principalmente as necessidades dos alunos.

Muitas vezes o professor participa de quase todas as etapas de vida de um aluno como por exemplo, crianças, jovens e adultos, mas algumas vezes a fase da adolescência é a mais temida por parte de alguns, por ser uma fase difícil de lidar. Basso (2008 p.115) lembra que os adolescentes muitas vezes são rotulados como "aborrescentes, cansativos, malcriados, barulhentos, distraídos, agressivos, difíceis..." e ainda ressalta que a lista para descrever os adolescentes é longa e também é quase sempre carregada de significação negativa e preconceitos por parte dos pais, professores ou adultos em geral.

Não se pode negar que é mesmo uma fase difícil, mas os professores têm que saber lidar com essa fase, pois faz parte da profissão daqueles que trabalham com o ensino fundamental e ensino médio e é normal tê-los em volta. Mas o "saber lidar" está envolvido com a formação do próprio professor também. É importante ter uma boa formação para que esses adolescentes não venham ser rejeitados também no ambiente de ensino.

Outro ponto importante é a produção de materiais autênticos, documentos escritos ou orais que permitem que o aluno tenha contato com a língua estrangeira e sua 
cultura. As NTICs podem ser tomadas como um bom exemplo de tais recursos, para aquisição da aprendizagem de língua estrangeira, como materiais que venham auxiliar na escrita e leitura no ensino de línguas.

Em uma coleção editada por Tomlinson (1998) que tem por título "Materiais Desenvolvimento em Ensino de Línguas", vemos que se faz pouca referência à contribuição de computadores, diferentemente do que faz Maley (1998), quando diz que estamos no início de uma geração na qual os materiais para o ensino de línguas são informatizados.

Segundo Chapelle (2001, p. 2), uma pessoa que se preocupa com a linguagem de ensinar no século XXI "precisa compreender a natureza das tarefas únicas mediadas por tecnologia que os alunos podem participar". Dessa forma, é sabido afirmar a importância dos materiais eletrônicos como ferramenta no ensino de línguas, pois estão interligados com a nova geração à qual os alunos pertencem.

Assim, como esses autores tratam as tecnologias como auxiliadoras no processo de ensino-aprendizagem, devemos também usá-las para aperfeiçoar o ensino de línguas, pois favorece essa nova geração que está cada vez mais ligada as novidades da tecnologia, e, com isso, podemos tratar a tecnologia como um método de ensino.

\section{TICs e ensino}

Paiva (2013) faz uma breve apresentação histórica sobre o uso de tecnologias no ensino de língua estrangeira, começando pelos recursos tipográficos até o desenvolvimento dos equipamentos eletrônicos. Na visão da autora, 
o ensino de línguas nas escolas busca inserir as novas tecnologias nas práticas pedagógicas, como uma tentativa de melhorar a mediação entre os alunos e a língua alvo. Nesse contexto, o professor que utilizar as tecnologias em suas aulas certamente estará contribuindo com o processo de aprendizagem de seus alunos.

As novas tecnologias estão cada vez mais presentes em nossas vidas e mudou a maneira de pensar da sociedade. Diante desse cenário, a cada dia um novo dispositivo é criado, em que pese o fato de que a educação básica se encontra há tempos mantendo-se dentro das mesmas diretrizes e sem nenhuma evolução ou mudança concreta. Assim, se para os professores antes, era difícil manter a atenção de seus alunos, que não tinham em mãos ferramentas que os distraíssem, hoje essa tarefa se tornou quase impossível.

Muitos professores ainda não se sentem seguros para utilizar as novas tecnologias em sala de aula por vários motivos, como por exemplo, não saber usar o computador e seus recursos como ferramenta pedagógica. Acreditamos que a dificuldade é atribuída a vários fatores como a deficiência na formação profissional, a falta de tempo, o pouco incentivo da própria escola para o aprimoramento desses professores. Segundo Kenski:

É necessário, sobretudo, que os professores se sintam confortáveis para utilizar esses novos auxiliares didáticos. Estar confortável significa conhecê-los, dominar os principais procedimentos técnicos para sua utilização, avaliá-los criticamente e criar novas possibilidades pedagógicas, 
partindo da integração desses meios com o processo de ensino (KENSKI 2003, p.77).

Hoje, esses alunos que já nascem na era digital fazem o uso constante de ferramentas tecnológicas que lhes permitem fazer pesquisas, comunicar-se e publicar, mas nem sempre fazem o uso dessas tecnologias com propósito de autoaprendizagem. É por essa razão que o professor tem um papel essencial pois é ele quem deve dar direcionamentos de como utilizar tais ferramentas para o ensino e aprendizagem. Mas não são só essas barreiras enfrentadas, quando se trata da utilização dessas novas tecnologias da informação e comunicação no ensino. Santos, Beato e Aragão (2012) citam algumas barreiras encontradas: “[...] níveis de confiança, quantidade de suporte técnico disponível, qualidade da formação, ausência de conhecimento técnico para operar os equipamentos, resistência à mudança".

Quando existem essas barreiras, elas afetam a utilização das novas tecnologias, pois os profissionais têm que saber dominá-las para se sentir confiantes perante os alunos. Mas, para que exista esse domínio, os professores têm que ter uma boa formação para que não venha resistir à mudança por não saber utilizá-las. Caberá à escola assumir novos papeis para suprir as necessidades desses professores, disponibilizado cursos para capacitá-los.

Portanto, vale lembrar que não é só ter essas tecnologias na escola, mas oferecer um ensino aos profissionais para que venham aperfeiçoar o conhecimento já existente e usá-las em benefício de todos. Do contrário, se não acontecer essa mudança, todos os equipamentos tecnológicos 
ficarão guardados dentro de caixas sem poderem ser utilizado, porque não se saber lidar com eles. É preciso investir na formação dos professores, pois é através deles que podemos pensar na transformação da escola nesse sentido.

NTICs e ensino de LE

Não se pode negar que, assim como o ensino de outras práticas pedagógicas, o ensino de língua estrangeira também tem tido como benefício o uso de novas tecnologias da informação e comunicação, mas também tem gerado grande discussões sobre esse novo modelo de aprendizagem mediado por dispositivos móveis.

As NTICs vêm auxiliando o ensino de LE. Nas duas últimas décadas esse auxilio se tornou muito importante em ambientes de ensino-aprendizagem. Hoje, com ajuda da internet e através de aparelhos móveis, seja ele o celular, o tablet ou o próprio notebook, o aluno tem uma grande facilidade de desfrutar de uma gama de serviços que podem ajudar no seu aprendizado, como, por exemplo, as bibliotecas virtuais, os bate-papos, os correios eletrônicos, as redes sociais, entre outros.

Essa realidade que estamos vivenciando, da união das NTICs com o ensino de línguas é um fator muito importante e que, a partir dessa união, tem gerado grandes benefícios para a educação. Mas, segundo Lopes (2012, p.5), muitas instituições ainda apresentam dificuldades para inserir essas tecnologias na sala de aula e se adequarem aos tempos atuais. Ela afirma que: 
As novas tecnologias de informação e comunicação têm influenciado significativamente a educação, de modo a realçar a sua importância para o desenvolvimento social. Muitas instituições de ensino, no entanto, ainda apresentam grandes dificuldades para adequarem-se às rápidas transformações dos tempos atuais. Isto porque as novas demandas tecnológicas exigem dos alunos capacidade de raciocínio, habilidades verbais e numéricas específicas, maior poder de reflexão e criação de novas formas de conhecimento (LOPES, 2012, p.5).

Já para Kenski a educação tem um papel fundamental, pois é por meio dela que podemos ter acesso ao conhecimento necessário e, a partir desse conhecimento, é que poderemos dominar as tecnologias e compreendê-las melhor. Entretanto, a educação tem esse desafio de desempenhar esse papel, e também adaptar-se a essa nova realidade de um mundo tecnológico. Ela afirma que "esse também é um duplo desafio da educação: adaptar-se aos avanços das tecnologias e orientar o caminho de todos para o domínio e apropriação crítica desses novos meios" (KENSKI, 2008, p.18).

$\mathrm{Na}$ área educacional, vem crescendo o número de dispositivos móveis e recursos digitais que promovem mudanças no modelo tradicional da educação. Com o surgimento dos recursos tecnológicos, nasceu o EAD (ensino à distância), modelo de ensino conhecido desde o século XIX, e que nasceu da necessidade 
de preparar profissionalmente pessoas que, por vários motivos, não podiam estar presentes em um ambiente de ensino presencial. Esse tipo de ensino contempla também o desenvolvimento da autonomia do próprio aluno, pois ele é desafiado a pesquisar o conteúdo e entendê-lo.

Tal modalidade se encaixa no modelo $e$ - Learning, que resulta de uma combinação ocorrida entre o ensino com auxílio da tecnologia e educação a distância, é concentrado em educação online. Assim como o ensino a distância, existem outras ferramentas tecnológicas que permitem que o aluno tenha um perfil autônomo e vá em busca do seu próprio conhecimento, como, por exemplo, o celular, o notebook ou tablet. Essas são ferramentas que geralmente estão mais presentes na vida dos jovens e, por isso, elas podem ajudar no aprendizado desses alunos.

Quando o aluno tem o interesse pelo desenvolvimento da língua estrangeira, ele apela para algumas coisas fora do ambiente de ensino, como por exemplo, ouvir música, assistir TV, assistir filmes com legendas, conversar com outros falantes da língua, entre outras atividades. Mas, segundo Paiva (2009, p. 33), isso raramente acontece dentro da escola:

A sala de aula, geralmente, não oferece atividades de uso da língua, mas apenas exercícios sobre determinados itens gramaticais onde a língua é tradada de forma artificial ou, ainda, a tradução de textos escolhidos pelo professor e que nem sempre são de interesse do aluno. 
Portanto, se esse aluno fosse motivado a usar dentro da sala de aula essas ferramentas tecnológicas que eles usam fora do ambiente de ensino, tornaria o ensino de língua inglesa mais atraente e interessante para que viessem ter um bom desenvolvimento na aprendizagem da língua.

NTICs e ensino de LI

Para o ensino de uma língua estrangeira, em especial o inglês, sempre se fala em quatro habilidades que são: ler (Reading), escrever (Writing), ouvir (Listening) e falar (Speaking). Entretanto, sabemos que desenvolver todas essas habilidades nas escolas públicas não é uma tarefa fácil, por motivos de carga horária, salas numerosas, ausências de material instrucional, entre outros fatores. Sendo assim, é impossível exigir que os alunos saiam das escolas capazes de ler, escrever ouvir e falar inglês.

O ensino de LI tem carga horária reduzida e quebra de horários, por tanto sabemos que é impossível que o aluno saia falando o idioma fluentemente se ele ficar somente restrito no ambiente da sala de aula, por melhor que seja o ensino. Esse pouco tempo que tem na sala precisa ser utilizados de forma que desperte o aluno a buscar novas experiências com a língua.

Porém, sabemos que o conhecimento de uma língua estrangeira é direito do cidadão, pois é um método de inclusão social, mas apesar disso, não podemos deixar de dizer que ele é falho, principalmente quando se trata do nosso ensino público. Com as inúmeras falhas existentes, na maioria dos casos, os alunos chegam no ensino superior em um curso de letras, por exemplo, sem ter nenhum domínio da língua inglesa e isso acaba gerando grandes 
dificuldades na vida acadêmica desse aluno, e muitas vezes acabam concluindo o ensino superior e não conseguem, por exemplo, se comunicar usando o idioma.

Entretanto, o emprego das novas tecnologias poderá tornar o aprendizado mais fácil, pois é uma fonte inovadora de conhecimento. Aqueles que fazem o uso dessas ferramentas precisam estar em um aprendizado constante, segundo Kenski (2008, p.104), para que "possam sair do cerco fechado da sala de aula e do ambiente escolar para conectarem-se ao mundo".

No ensino-aprendizagem de língua inglesa podemos destacar a internet como ponto importante, pois possibilita que o aluno tenha acesso a várias mídias e, com isso, tornar o aprendizado mais atraente e divertido, além de favorecer a relação entre professor e aluno, possibilitando a troca de informação, receber feedback, fazer trabalhos em grupo, praticar o idioma entre outras coisas que ela nos possibilita realizar.

Segundo Peixoto e Siqueira, hoje a maioria dos alunos que chega à educação básica se insere na chamada Geração $\mathrm{Z}$, que também é conhecida por "nativos digitais", "homo zappiens", "geração digital" ou "geração internet". Eles também afirmam que:

Esses jovens estão cercados por informações praticamente o tempo todo que, devido ao grande volume em circulação, acabam se tornando obsoletas rapidamente. Como eles cresceram com a evolução das novas tecnologias, principalmente da internet, as NTIC foram incorporadas ao seu dia a dia, sendo utilizadas nos 
estudos, na vida diária e até nas relações sociais. (PEIXOTO; SIQUEIRA, 2015 p.68).

Eles ainda ressaltam que um ponto a ser considerado importante é que, além dessa geração estar mais envolvida com o consumismo, ela também está envolvida com a produção de informações online. Hoje, existe um certo conflito de gerações em sala de aula, entre professores, que nasceram na época em que ainda não existiam as novas tecnologias e alunos, que já nasceram rodeados por elas. Para acompanhar esses alunos da geração digital, “o professor também tem que mudar seu perfil e sua pratica pedagógica", afirma Xavier (2012, p.3). Ele ainda continua dizendo que o mestre precisa ser:

- Pesquisador, não mais repetidor de informação;

- Articulador do saber, não mais fornecedor único do conhecimento;

- Gestor de aprendizagens, não mais instrutor de regras;

- Consultor que sugere, não mais chefe autoritário que manda;

- Motivador da "aprendizagem pela descoberta", não mais avaliador de informações empacotadas a serem assimiladas e reproduzidas pelo aluno.

Esses pontos, sustentados por Xavier (2012), mostram que o professor quando adquire esse perfil, torna- se mais fácil para ele acompanhar esses alunos que estão cada vez mais aprendendo fora do ambiente escolar, com os recursos tecnológicos. Para obter sucesso durante o ensino de 
LI, o professor precisa adentrar no mundo tecnológico que seu aluno já domina com facilidade, o uso das NTICs, promovendo, assim, um feedback entre aluno e professor, de modo que ambos dominem os recursos e reconheçam que essa ferramenta é de grande importância para o ensino aprendizagem.

Aplicativos e ensino de L.I

Os aplicativos, mais conhecidos como APPs, são instalados em Smartphones, na maioria das vezes, de forma gratuita. Podem ser um grande aliado para quem quer aprender a língua inglesa sem ter nenhum custo, bastando apenas que tenha um aparelho celular para ter acesso a esses aplicativos. É uma ótima alternativa para quem deseja aprender inglês de forma prática e divertida. Mas é preciso entender que os aplicativos têm diferentes metodologias e também podem ser usados para aperfeiçoamento das quatro habilidades. Existe uma variedade de aplicativos para aprender o inglês. Eis alguns aplicativos que podem ser utilizados e as características de cada um:

$\diamond$ Duolingo: é focado no vocabulário, escrita e na compreensão oral, apresenta a cada dia, lições separadas por temas do nosso dia a dia. Talvez seja o mais conhecido e o mais utilizado quando o assunto é aprender inglês. Funciona no modo de jogo e os níveis vão avançando o que acaba tornando a aprendizagem divertida. É um aplicativo gratuito e possibilita o usuário estudar mais de quatro línguas ao mesmo tempo. É livre de anúncio. 
Figura 1: Aplicativo Duolingo

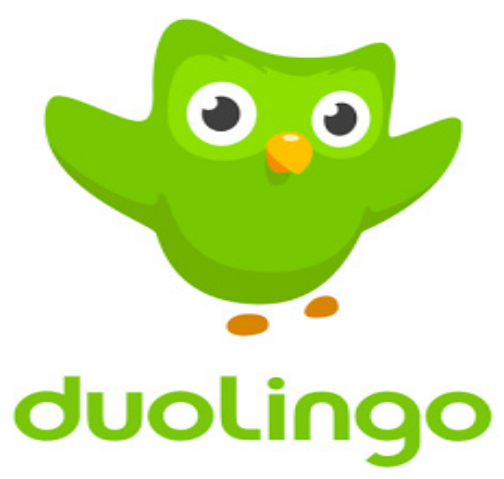

Fonte: https:/ / play.google.com/store/apps/details?id=com. duolingo\&hl=pt_BR

$\diamond$ Hello English: é um excelente aplicativo para quem não quer ficar somente restrito à memorização de palavras, mas receber explicações e dicas durante o processo. É apresentado como um dos melhores aplicativos de 2016, do Google. Suas funcionalidades são:

- 300 lições interativas $100 \%$ gratuitas com conversação em inglês, tópicos gramaticais e vocabulários. Todas as lições também funcionam no modo off-line;

- Conversar com professores, fazer perguntas sobre gramática e traduções;

- Praticar usando notícias diárias;

- Jogo de pratica de conversação sobre tópicos do dia a dia;

- Dicionário de 10.000 palavras. 
Figura 2: Aplicativo Hello English

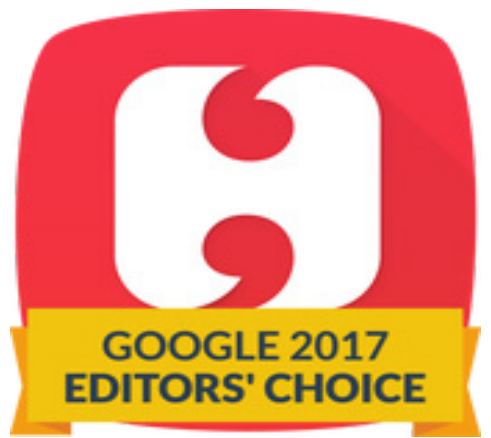

Fonte: https:/ / apkpure.com/br/hello-english-learn-english/ com.CultureAlley.japanese.english

$\diamond$ Lingualeo: é um aplicativo que permite que o usuário interaja com aprendizado e a prática do inglês, ideal também para quem não quer ficar só nas lições. Nele o usuário encontra vários tipos e conteúdos e seções para estudar de acordo com o que desejar e é adequado tanto para o público adulto quanto para o infantil. Para tanto, constitui-se de:

- Aprendizado de inglês gratuito;

- Dicionário pessoal com associações individuais, transcrições e áudio para cada palavra;

- Glossários temáticos com associações visuais;

- Treinos eficazes: tradução, construtor de palavras e compreensão oral;

- Possibilidade de escolher a melhor tradução;

- Dispositivo que permite que o progresso no aprendizado da língua seja monitorado em tempo real. 
Figura 3: Aplicativo Lingualeo

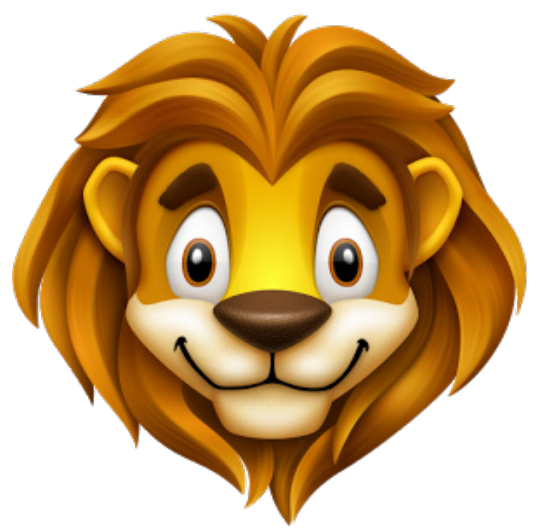

Fonte: https:/ / play.google.com/store/apps/details?id=com. lingualeo.android\&hl=pt_BR

Estes são alguns dos aplicativos que enriquece o aprendizado do aluno sendo um avanço no conhecimento e técnicas do professor de L.I e também possibilitam que os alunos aprendam fora da sala de aula. Segundo Gonçalves (2014):

Para a área educativa o número de APPs ainda é relativamente pequeno quando comparado a APPs de outras áreas como a de jogos por exemplo. Mas é notável já o interesse de desenvolvedores desses aplicativos para a área da educação.

Hoje com as funções oferecidas pelos Smartphones temos grandes possibilidades de acesso ao nosso próprio conhecimento, as informações surgem de maneira instantânea, o que vem ser de grande importância nos tempos 
atuais. Gonçalves (2014) afirma que no ensino de línguas os APPs são o destaque, por possibilitar a liberdade e pela facilidade de aprender uma determinada língua:

O ensino de línguas vem sendo destaque entre os APPs educativos, isso porque a liberdade e a facilidade de acesso a conhecimentos de línguas por meio de APPs têm despertado uma nova metodologia de aprendizagem, que nesse meio é autônoma, prática e gerenciável pelo aluno que os adaptam às suas necessidades de estudos (GONÇALVES, 2014, p. 3).

Os aplicativos fazem com que os usuários interajam e tenham facilidade em sua manipulação, oferecem também exercícios e avaliações práticas. Apesar dos benefícios que esses aplicativos trazem para a educação e pela quantidade de informações que eles carregam, eles não são tão valorizados, quando se trata de ensino/aprendizagem de línguas. Portanto, é necessário que seja despertado o interesse de se fazer trabalhos nessa área para mostrar que também é possível aprender a partir deles.

WhatsApp e ensino de L.I

O WhatsApp Messenger é um aplicativo de mensagens que permite aos seus usuários a troca de mensagens por aparelho móvel. O uso desse aplicativo tem grandes vantagens para o ensino de LI, sendo uma delas o fato de que os usuários podem criar grupos, enviar mensagens ilimitadas e fazer o compartilhamento de imagens, vídeos e 
áudios. O uso desse aplicativo no ensino de línguas, principalmente no ensino de LI, tem muitos aspectos positivos. Segundo Church e Oliveira o WhatsApp:

Éuma multiplataforma de mensagens instantâneas para smartphones. Ele permite que o usuário envie e receba informações de localização, imagens, vídeo, áudio e mensagens de texto em tempo real para indivíduos e grupos de amigos, sem custo (CHURCH E OLIVEIRA 2013, p.352).

O uso das NTICs no ambiente escolar não é um assunto novo nas pesquisas, pois muitos professores fazem o uso dessas tecnologias de alguma forma, mas, quando se fala em celular em sala de aula, não é um assunto aceito por parte de alguns: ou dizem que o uso do celular pode atrapalhar na aprendizagem, ou que a escola não é o ambiente adequado para se usar tal ferramenta. Já para Zardini (2015, p. 3), o uso de celulares e aplicativos de mensagens como o WhatsApp é relativamente novo, e, embora não tenha sido criado para ser utilizado no ensino, também apresenta boas oportunidades quando é usado para este fim, principalmente como ampliação das atividades de sala de aula.

O uso do WhatsApp pode ser, portanto, um grande aliado ao ensino de LI. Através de uma pesquisa feita por Zardini, percebe-se que o uso do aplicativo WhatsApp foi aceito pelos alunos como um ponto positivo. Ela afirma que:

O que mais se destaca nas falas desses alunos é o ambiente informal/ descontraído das discussões geradas 
pelo grupo, o aumento da comunicação entre os alunos, a troca de informação e conhecimento, a interação entre os alunos, o contato com a língua e a descontração propiciada pelo ambiente (ZARDINI, 2015, p.6).

Mas é importante ressaltar que o uso dessa ferramenta não dispensa o papel do professor, pois ele é indispensável e é através dele que será mostrado como fazer a utilização desses recursos para melhorar o ensino de LI. É uma forma descontraída de se aprender uma língua, dando possibilidades aos alunos de se comunicarem com outros falantes da língua no mundo todo, de forma simultânea e sem custo.

Outro ponto importante é que, para aqueles alunos que têm dificuldade de se expressar diante do grupo, o uso do WhatsApp possibilita mais tempo para organizar a maneira de se expressar, o que diminuirá sua ansiedade e o medo de se expor para o grupo da sala de aula, pois se dará através do ensino a distância, sem falar que através do aplicativo o aluno tem a possibilidade de praticar as quatro habilidades - reading, writing, listening e speaking ao mesmo tempo.

Antes, o acesso à internet era considerado precário, mas hoje, com as operadoras de telefonia celular e com a grande distribuição de pontos wi-fi, a comunicação tornou-se acessível até mesmo para pessoas que moram em localidades distantes dos centros urbanos. Além dos benefícios já citados anteriormente, existem outros apresentados pela UNESCO (PORVIR, 2013) que mostra treze bons motivos e dez recomendações para governos sobre $o$ uso de tecnologias móveis na escola. 
Com todos esses motivos e recomendações apresentadas só reforça os benefícios que temos ao fazer utilização dessa ferramenta, e o quanto ela pode ajudar a melhorar o ensino/aprendizado de língua inglesa, pois ela oferece facilidade de aquisição, pode ser baixado em todos os celulares com o sistema android, Windows phone ou IOS e é um aplicativo popular entre os adolescentes e ele também permite que o aluno organize seu tempo de estudar.

Em uma pesquisa feita por Zardini (2015) sobre o uso do aplicativo de mensagem whatsApp, ela teve como experimento o grupo de 20 alunos que fizeram parte de um curso de extensão do CEFET- MG - CLIC (centro de língua e cultura). O grupo de alunos era composto por duas turmas com o mesmo nível de proficiência, e ela pôde constatar inicialmente uma certa timidez por parte dos alunos, necessitando de um incentivo para que eles interagissem, mas os resultados satisfatórios vieram ao longo prazo afirma Zardini:

De maneira bastante generalizada, pude constatar que a participação inicial foi bastante tímida, sendo necessárias muitas ações de incentivo para que os alunos participassem. Entretanto, apesar da timidez inicial, os resultados no longo prazo se mostraram satisfatórios. (ZARDINI, 2015, p. 4).

Portanto, é possível considerar que o uso desse recurso no ensino/aprendizagem é relativamente novo e que ainda possa existir uma certa rejeição, apesar de ter vários estudos já realizados sobre o uso positivo dessa ferramenta para o ensino. Assim como a sua utilização permite que o 
professor seja um pesquisador e deixe de repetir informações, ela também faz com que o aluno trabalhe na construção do seu próprio conhecimento, pois estão usando ferramentas de seu domínio. E com isso o professor motiva cada um deles a aprender mais sozinhos e em grupos.

Figura 4: Motivos e recomendações para usar tecnologias móveis em sala de aula

\begin{tabular}{|c|c|}
\hline Bons Motivos & Recomendações \\
\hline $\begin{array}{l}\text { Amplia o alcance e a } \\
\text { equidade da educação }\end{array}$ & $\begin{array}{l}\text { Criar ou atualizar } \\
\text { politicas ligadas ao }\end{array}$ \\
\hline $\begin{array}{l}\text { Melhora a educação em } \\
\text { áreas de conflito ou que } \\
\text { sofreram desastres naturais }\end{array}$ & $\begin{array}{c}\text { aprendizado móvel } \\
\text { Conscientizar sobre sua } \\
\text { importância }\end{array}$ \\
\hline Assiste alunos com deficiência & Expandir e melhorar \\
\hline $\begin{array}{c}\text { Otimiza o tempo na } \\
\text { sala de aula }\end{array}$ & $\begin{array}{l}\text { opçôes de conexão } \\
\text { Ter acesso igualitário }\end{array}$ \\
\hline $\begin{array}{c}\begin{array}{c}\text { Permite que se aprenda em } \\
\text { qualquer hora e lugar }\end{array} \\
\text { qual }\end{array}$ & $\begin{array}{c}\text { Garantir equidade } \\
\text { de gênero }\end{array}$ \\
\hline $\begin{array}{c}\text { Constrói novas comunida- } \\
\text { des de aprendizado }\end{array}$ & $\begin{array}{c}\text { Criar e otimizar } \\
\text { conteúdo educacional }\end{array}$ \\
\hline $\begin{array}{c}\text { Dá suporte à } \\
\text { aprendizagem in loco }\end{array}$ & Treinar professores \\
\hline $\begin{array}{l}\text { Aproxima o aprendizado } \\
\text { formal do informal }\end{array}$ & $\begin{array}{l}\text { Capacitá-los usando } \\
\text { tecnologias móveis }\end{array}$ \\
\hline $\begin{array}{c}\text { Provê avaliação e } \\
\text { feedback imediatos } \\
\end{array}$ & $\begin{array}{l}\text { Promover o uso seguro, } \\
\text { responsável e saudável }\end{array}$ \\
\hline Facilita o aprendizado & das tecnologias \\
\hline personalizado & Usá-las para melhorar a \\
\hline $\begin{array}{c}\text { Melhora a aprendizagem } \\
\text { contínua }\end{array}$ & $\begin{array}{c}\text { comunicação e a gestão } \\
\text { da educação }\end{array}$ \\
\hline Melhora a comunicação & \\
\hline $\begin{array}{c}\text { Maximiza a relação custo- } \\
\text { benefício da educação }\end{array}$ & \\
\hline
\end{tabular}

Fonte: adaptado de Porvir, 2013. 


\section{Aplicativo de mensagem e ensino de LI: sugestão de atividade}

Nesta seção, será apresentado um quadro sugestivo mostrando a utilização das novas tecnologias no ensino de língua inglesa, seguindo um propósito de que precisamos considerar que seu uso tornou-se uma necessidade da qual não podemos prescindir. Em seguida, será apresentada uma proposta de ensino direcionada ao nível escolar fundamental II, enfatizando o aplicativo de mensagem WhatsApp como instrumento de trabalho nas aulas de língua inglesa. A intenção do desenho da atividade é que esta proposta possa servir como base para outros professores que desejam fazer o uso desse aplicativo em suas aulas.

O uso do aplicativo deve estar no contexto do conteúdo proposto para uma determinada aula, seja ela teórica ou prática, facilitando a mediação entre aluno, professor e o assunto abordado no plano de aula. Dessa forma, o uso do aplicativo irá proporcionar e desenvolver habilidades no aprendizado do aluno de uma forma inovada e satisfatória. Pensando nisso, elaboramos três grupos, mostrando como utilizá-la de forma produtiva e para aproximação da comunidade escolar em geral.

- Corpo docente: É essencial a aceitação desses profissionais para adoção das novas tecnologias na escola, pois eles é quem irão lidar primeiramente com elas e, portanto, é necessário que estejam a favor da mudança. Desse modo, irão ser os motivadores para o uso das tecnologias, embora seja preciso que eles tenham ajuda para inseri-las da 
melhor forma, como, por exemplo, treinamentos e aulas com profissionais de informática, deixando-os mais seguros para utilizar o aplicativo na sala de aula. O WhatsApp pode ser usado pelos professores para facilitar a troca de experiências sobre suas práticas pedagógicas, indicar materiais, livros e atividades.

- Pais e responsáveis: Sabemos que o envolvimento dos pais é muito importante na formação de seus filhos, mas nem sempre eles conseguem fazer o acompanhamento necessário. Sendo assim é importante que exista sua participação na escola, sendo informados do calendário escolar acerca dos conteúdos e recursos usados pelos professores em atividades para seus filhos. Essa mediação entre pais/responsáveis e escola muitas vezes é dificultada por motivos superiores e, com o uso das novas tecnologias, possibilita-se aproximar os pais para que, juntos com os docentes, tomem decisões sobre a implementação do aplicativo de mensagens em sala de aula, que serão fundamentais no aprendizado dos alunos e principalmente na socialização entre pais e mestres. Com essa ferramenta, pode-se criar um grupo para aproximar os pais da rotina escolar de seus filhos, podendo ser usada para enviar recados gravados ou escritos, agenda de atividades, informações de possíveis eventos, comunicados importantes, relatório do desempenho escolar dos filhos.

- Alunos: Como os alunos já nascem imersos nas novas tecnologias, é provável que não haja nenhuma rejeição na implementação do aplicativo 
por parte deles, quanto ao uso das tecnologias durantes as aulas, auxiliando em sua educação. Mesmo assim, é preciso um acompanhamento em seu uso para que eles não saiam do foco, que é o seu aprendizado. É de grande estratégia do professor explicar as vantagens e seus objetivos com relação ao ensino de língua inglesa antes de fazer o uso da nova tecnologia, pois, em relação aos aplicativos, os alunos vêm com um conceito formado de que ele só serve para trocar mensagens, com amigos e parentes. Dessa forma, o professor apresenta a ferramenta mostrando a ludicidade em relação ao ensino e aquisição de cada um e o uso irá desenvolver as habilidades de ouvir, ler, escrever e falar em inglês.

Diante das apresentações da inserção do uso da tecnologia no ambiente escolar de uma forma que unificou todos os responsáveis pela educação eaprendizagem dos alunos, podemos ressaltar a importância tanto do uso de novos aplicativos, como o WhatsApp, quanto da presença dos pais/responsáveis na escola. Apresentamos a seguir o modelo da proposta de ensino utilizando o aplicativo de mensagens WhatsApp, como tarefa de casa para a prática oral, escrita e de vocabulário.

Objetivo: usar o aplicativo WhatsApp para que o aluno possa praticar a oralidade, a escrita e a aquisição e manejo de vocabulário em LI.

Conteúdo: o conteúdo que servirá como tema para mensagens orais e escritas no WhatsApp será relacionado com temas desenvolvidos durante as aulas. 
Desenvolvimento do tema: o desenvolvimento das atividades será realizado durante cada unidade temática trabalhada em sala.

Materiais: Aparelho de telefonia móvel celular, smartphone, ou tablet com aplicativo WhatsApp instalado.

Avaliação: Os alunos serão avaliados através da participação nas atividades no grupo do WhatsApp, e será considerada também sua evolução na escrita, na oralidade e no desenvolvimento do vocabulário.

Antes de tudo o professor deverá se certificar se todos possuem um aparelho móvel como, por exemplo, celular smartphone ou tablet. Em seguida, cada um precisará instalar o aplicativo em seus aparelhos com ajuda do professor. Talvez não seja necessária a instalação, por ser um aplicativo popular e muito utilizado hoje em dia.

Depois de se certificar de que todos os aparelhos estão com o aplicativo, junto com a turma, o professor irá criar um grupo no WhatsApp para a comunicação dos alunos como trabalho extra-sala. No final de cada unidade temática que for sendo trabalhada com eles em sala, será proposta pelo professor uma atividade escrita e oral para ser trabalhado o vocabulário que será desenvolvido, através do aplicativo, lidando assim com o desenvolvimento das habilidades propostas.

Em dupla, o professor irá selecionar com base no vocabulário que foi utilizado durante as aulas em sala, frases e palavras e deverá escolher quem da dupla ficará responsável pela gravação e quem ficará encarregado da escrita, lembrando que quem ficar responsável pela escrita vai estar trabalhando com a atividade de compreensão oral também. O professor irá pedir que o aluno grave uma 
frase ou palavra das que foram propostas e envie para o outro e, sempre o que receber o áudio ouvirá e retornará por escrito o que entendeu por mensagem de texto.

Como essa atividade será feita através do grupo é interessante que o professor imponha critérios para as duplas para evitar desorganização. O interessante é que a cada atividade o professor troque a ordem dos alunos. Por exemplo, o que gravou na primeira atividade irá escrever na segunda e vice-versa.

O tempo para a atividade terá duração de 50 minutos, para que todas as duplas participem. Depois os alunos serão avaliados pelo seu desempenho, participação e principalmente pela sua evolução nas atividades. O possível problema, antecipadamente previsto, é uma falha na conexão com a internet, pois o aplicativo só funciona se houver sinal, de preferência wi-fi.

Embora esta proposta tenha sido elaborada para se trabalhar a compreensão oral, escrita e vocabulário, vale lembrar que são inúmeras as atividades que podem ser desenvolvidas através desse aplicativo e é possível o aprendizado do inglês por meio dele, principalmente pela familiaridade no trato com tal recurso tecnológico.

\section{Considerações Finais}

Esta pesquisa teve como principal objetivo despertar o interesse dos profissionais da área educativa, principalmente os professores de língua inglesa, a serem engajados nesta corrente que busca incentivar o uso das novas tecnologias como ferramenta para apoiar a construção do conhecimento. 
Procuramos demonstrar que, através delas, podemos criar metodologias criativas, inovadoras e dinâmicas, na urgência de atuação de uma prática docente reflexiva, pois sabemos que, para tal, precisamos revisar nossas formas de ensinar e pensar na modificação não só para si próprios, mas para todos que fazem parte da comunidade escolar e visar principalmente às necessidades dos alunos.

Neste sentido, demonstramos que as novas tecnologias da informação e comunicação podem trazer melhorias para o ensino de língua inglesa e, como tais, podem ser consideradas como método de ensino, uma vez que estes remetem às formas pelas quais o professor trabalha os diversos conteúdos com seus alunos, com o fim de alcançar o objetivos propostos.

Assim, o professor que fizer a utilização das NTICs tende a favorecer essa nova geração, que já nasce imersa nelas, contexto que propicia ao professor e ao aluno oportunidades de interação, através de recursos digitais que podem ser inseridos na prática pedagógica, seja no espaço da sala de aula ou fora dela.

Já no que tange ao campo do ensino/aprendizagem de língua inglesa, em que pese o fato de termos feito menção sobre a existência de diversos aplicativos, como o Duolingo, o Hello English, o Lingualeo, mais voltados para o aprendizado do inglês, como língua adicional, sabemos que essa área precisa ser vista com outro olhar e dada uma importância maior. Os aplicativos possibilitam que o aluno tenha facilidade de aprender determinada língua, sem custo e de modo dinâmico.

Em seguida, discorremos acerca do foco principal deste trabalho, que é a utilização do aplicativo WhatsApp, como recurso auxiliar nas aulas de língua inglesa. Foram 
apresentadas algumas formas de se trabalhar com ele, para a aproximação de toda a comunidade escolar e também para melhorar o aprendizado dos alunos: apesar de não ter sido desenvolvido para esse intuito, de caráter pedagógico, sabemos da possibilidade de sucesso em práticas de ensino/aprendizagem de a língua inglesa especialmente quanto às atividades de escuta, escrita e desenvolvimento de vocabulário.

Podemos acrescentar que, a partir do panorama aqui desenvolvido, pôde-se constatar ser possível imprimir mudanças com relação ao ensino/aprendizagem de língua inglesa, principalmente quanto à importância dada ao uso das NTICs como auxiliadoras no processo.

Esperamos, portanto, que o presente estudo possa vir contribuir não só para a aprendizagem da compreensão oral, escrita e vocabulário, mas para fomentar o desenvolvimento de outras habilidades e que, através da conscientização dos profissionais do ensino de língua inglesa com relação ao uso dessas novas ferramentas, estes possam enxergar as múltiplas possibilidades de atividades que as novas tecnologias nos permitem desenvolver.

\section{Referências}

BASSO, E. Adolescentes e a aprendizagem de uma língua estrangeira: características, percepções e estratégias. In: ROCHA, C,: BASSO, E. Ensinar e aprender lingua estrangeira nas diferentes idades: reflexão para professores e formadores. São Carlos: editora Claraluz, 2008.

CHAPELLE, C. Computer applications in second language acquisition. Cambridge: Cambridge University Press, 2001. 
CHURCH, K.; OLIVEIRA, R. What's up with WhatsApp? Comparing Mobile Instant Messaging Behaviors with Traditional SMS. 15th International Conference on HumanComputer Interaction with Mobile Devices and Services, 2013.

DONNINI, Lívia; PLATERO, Luciana. WEIGEL, Adriana. Ensino de lingua inglesa. São Paulo: Cengage Learning, 2010.

GANDOUR, D. A reflexão crítica e a utilização de textos no ensino de língua estrangeira. In: ARAÚJO, S.; GALVÃO, M.; VIAN JR. O. O ensino e a pesquisa em língua inglesa na universidade: mapeando caminhos, explorando novas trilhas. Natal: Editora da UFRN, 2014.

GIL, Antonio Carlos. Métodos de pesquisa social. São Paulo: Atlas, 2008.

GONÇALVES, Jessica. Inglês na palma da mão: possibilidades de aprendizagem através dos dispositivos móveis conectados à internet. Revista de Estudos Acadêmicos de Letras. Cáceres, v. 7, n. 1, 2014.

KENSKI, V. M. O ensino e os recursos didáticos em uma sociedade cheia de tecnologias. In: VEIGA, Ilma (Org.). Didática: o ensino e suas relações. Campinas: Papirus, 1996.

KENSKI, V. M. Educação e tecnologias: o novo ritmo da informação. Campinas: Papirus, 2008.

LOPES, Diana. As Novas Tecnologias e o Ensino de Línguas Estrangeiras. Recife, Revista Científica Tecnologus, v. 6, 2012. 
LEFFA, Vilson. Metodologia do ensino de línguas. In: BOHN, H. I.; VANDRESEN, P. (Org.) Tópicos em linguística aplicada: o ensino de línguas estrangeiras. Florianópolis: Ed. Da UFSG, 1988, p. 211-236.

MALEY, A. Squaring the circle - Reconciling materials as constraint with materials as empowerment. In B.Tomlinson (ed.). Materials development in language teaching. Cambridge: Cambridge University Press, 1998, p. 279-94.

OLIVEIRA, Luciano. Métodos de ensino de inglês: teorias, práticas, ideologias. São Paulo: Parábola, 2014.

. Aulas de inglês: do planejamento à avaliação. São Paulo: Parábola, 2015.

PAIVA, V.L.M. O uso da tecnologia no ensino de línguas estrangeiras: breve retrospectiva histórica, 2006. Disponível em: www.veramenezes.com/techist.pdf.

PAIVA, V.L.M. O ensino de língua estrangeira e a questão da autonomia. In: LIMA, D.C. (Org.) Ensino aprendizagem de lingua inglesa: conversas com especialistas. São Paulo: Parábola Editorial, 2009.

PEIXOTO, Roberta; SIQUEIRA. Domingos. Novas tecnologias nas aulas de inglês da escola pública: entre o desejável e o possível. Hipertextus, Revista Digital. Recife, v. 13, set. 2015. Disponível em < http://www.hipertextus.net/ volume13/revista-hipertextos-artigo4.pdf $>$

PORVIR. 10 dicas e 13 motivos para usar celular na aula. Site Porvir. 2013. Disponível em: <http://porvir. 
org/porfazer/10-dicas-13-motivos-para-usar-celularna-aula/20130225>. Acesso em: 29 de setembro de 2017.

SANTOS, Tássia; BEATO, Zelina; ARAGÃO, Rodrigo. As TICs e o ensino de línguas. Disponível em: http://www. uesc.br/eventos/sepexle/anais/10.pdf. Acesso em: 16 abr. 2012.

XAVIER, A. C. S. Letramento digital e ensino. Disponível em:http:/ / www.ufpe.br/ nehte/artigos/Letramento\%20 digital $\% 20 \mathrm{e} \% 20$ ensino.pdf. Acesso em:31 de agosto de 2017.

ZARDINI, A.S. O uso do whatsApp na sala de aula de língua inglesa-relato de experiência em um curso de idiomas. In: Simpósio sobre Materiais e Recursos Didáticos, 4., 2015, Rio de Janeiro. Anais... Rio de Janeiro: PUC/RJ, 2015. 


\title{
SOFTWARES APLICATIVOS COMO RECURSOS DIDÁTICOS: \\ A inserção de tecnologias digitais no contexto escolar
}

\author{
Iara Costa Nascimento ${ }^{1}$ \\ Simone Dália de Gusmão Aranha ${ }^{2}$
}

\section{Contextualizando a pesquisa}

Este texto apresenta o recorte de uma pesquisa concluída no Mestrado em Formação de Professores, da Universidade Estadual da Paraíba, campus I. Como diz respeito a um trabalho final de um Mestrado Profissional, modalidade de Pós-Graduação stricto sensu, que se dedica, particularmente, à capacitação de profissionais através

1 Mestre em Formação de Professores, pela Universidade Estadual da Paraíba, UEPB/PPGFP/Campus I. Licenciada em Pedagogia pela UEPB, com Especialização em Psicopedagogia pela FIP. Professora da rede municipal de ensino de Campina Grande/PB, atuando em sala de recursos multifuncionais (iaracn30@gmail.com.br).

2 Professora Associada da Universidade Estadual da Paraíba, Departamento de Letras e Artes, Campus I/Campina Grande. Doutora em Letras pela Universidade Federal da Paraíba UFPB. Coordenadora do Mestrado Profissional em Formação de Professores/UEPB. Líder do Grupo de Pesquisa LITERGE/ CNPq (Linguagem, Interação, Gêneros Textuais/Discursivos). (simone.dalia@yahoo.com.br). 
de estudo de técnicas, processos, fenômenos ou temáticas, conforme a demanda de um determinado mercado de trabalho, após ter sido aplicada a proposta em sala de aula e analisados os resultados obtidos, foi elaborado um produto pedagógico, no formato de Guia Digital (um tutorial), com orientações direcionadas a professores que desejem realizar uma proposta semelhante, adaptando, esse guia, aos seus contextos de ensino, à sua realidade escolar.

Sendo assim, considerando a questão da responsabilidade outorgada à escola contemporânea, c o mo principal agência de letramento - as práticas sociais mediadas pela cultura letrada nos diversos domínios da sociedade -, partimos de um eixo problematizador que direcionou o desenvolvimento desta pesquisa, a saber: Como favorecer aos alunos do $5^{\circ}$ ano, do Ensino Fundamental I, de uma escola municipal da cidade de Campina Grande/ $\mathrm{PB}$, a viabilização do letramento digital?

Norteados por essa questão investigativa, elaboramos os procedimentos metodológicos e decidimos desenvolver uma pesquisa ancorada por um paradigma epistemológico interpretativista, uma abordagem qualitativa, de natureza aplicada, do tipo explicativa. Ainda a classificamos como uma pesquisa-ação, pois de acordo com Severino (2007, p. 120):

a pesquisa-ação é aquela que, além de compreender, visa intervir na situação, com vistas a modificá-la. $\mathrm{O}$ conhecimento visado articula-se a uma finalidade intencional de alteração da situação pesquisada. Assim, ao mesmo tempo que realiza 
um diagnóstico e a análise de uma determinada situação, a pesquisaação propõe ao conjunto de sujeitos envolvidos mudanças que levam a um aprimoramento das práticas analisadas.

No que se refere ao aporte teórico, este estudo fundamentou-se em autores como: Street (2014), Soares (2009, 2012), Kleiman (2012), Rojo (2012), Lévy (1993, 1999), Arcoverde (2007), Aranha (2011) dentre outros. E quanto aos instrumentos utilizados para coleta de dados, foram utilizados: questionários de sondagem, observação participante, gravações em vídeo e áudio.

Ao consultar o produto educacional (o Guia Digital) que criamos, o professor poderá acompanhar todas as etapas do processo de confecção de um folheto informativo, utilizando o software Publisher. $\mathrm{O}$ folheto confeccionado por alunos foi organizado seguindo um tema escolhido, em votação, pela turma, que compreendeu a relevância dessa temática para a escola, lócus da pesquisa, e, por extensão, para todos da comunidade escolar que estavam inseridos.

O Publisher é um aplicativo que integra um grupo de programas da Microsoft Office, é utilizado para editar textos e permite a criação de publicações para impressão ou divulgação digital. Vale destacar que esse aplicativo não depende apenas do acesso à internet para realizar seus comandos, aspecto que representa uma facilidade para desenvolver a proposta em escolas que não dispõem de conexão com a rede. Além desse diferencial, escolhemos o Publisher por termos conhecimento de que esse aplicativo 
favorece uma interface entre o letramento das tecnologias tipográficas (tradicionais) e o letramento das tecnologias digitais (contemporâneas). Esse produto educacional pode ser gravado/copiado em mídia do tipo CD-R e ser manuseado em qualquer ferramenta digital com drive compatível com esse tipo de mídia, bem como o sistema operacional e o tipo de documento.

Ao fim do processo, e tomando por base a experiência vivenciada nesta investigação, foi possível constatar que essa ação pedagógi c a contribuiu para viabilização do letramento digital da turma participante. Além disso, verificamos a urgência de se promover o trabalho com letramentos digitais no âmbito escolar, tendo em vista que, a escola, muitas vezes, com base numa tradição de ensino simplista, ignora as necessidades educativas da atualidade, que se encontram imersas na cultura digital.

\section{Algumas considerações acerca da noção de letramento(s)}

Em decorrência da era digital, muitos professores buscam desenvolver as habilidades necessárias para exercer a docência utilizando as novas tecnologias, seja através de estudos, de formações continuadas ou de ingressos em Programas de Pós-Graduação. Nesse contexto, a escola tem sido cobrada a oferecer uma formação que capacite os alunos a fazerem uso dessas tecnologias, com autonomia e propriedade, devido a importância de se favorecer práticas sociais de leitura e de escrita (letramentos), com acesso a vários tipos de linguagens. É preciso possibilitar ao aluno não só decodificar o que está escrito, mas ir além dos elementos gráficos de um texto. 
Ao longo do tempo, os estudos sobre o fenômeno do letramento vêm se expandindo e várias vertentes dedicam-se a conceituá-lo. Contudo, devido a sua complexidade, esse termo não permite uma fácil definição, de acordo com as palavras de Soares (2009, p. 65):

Essa dificuldade e impossibilidade deve-se ao fato de que o letramento cobre uma vasta gama de conhecimentos, habilidades, capacidades, valores, usos e funções sociais; o conceito de letramento envolve, portanto, sutilezas e complexidades difíceis de serem contempladas em uma única definição.

Para Street, é possível compreender essa "dificuldade" de definir o termo, pois os seus significados e os seus usos variam segundo o contexto e os participantes envolvidos. Ao abrir um leque de possibilidades e possíveis definições e não a um único conceito isolado: "o letramento se relaciona tanto com o discurso oral quanto com práticas materiais específicas com as quais ele se entrelaça e se define" (STREET, 2014, p. 138).

Kleiman (2012, p. 16) explica que, inicialmente, o letramento teve seu conceito divulgado nos meios acadêmicos como tentativa de "separar os estudos sobre o 'impacto social da escrita' dos estudos sobre alfabetização, cujas conotações escolares destacam as competências individuais no uso e na prática da escrita". No entanto, ao longo do desenvolvimento de novos estudos e pesquisas, esse conceito foi transformando-se e ampliando-se, alcançando 
definições cada vez mais complexas: "podemos definir hoje o letramento como um conjunto de práticas sociais que usam a escrita, como sistema simbólico e como tecnologia, em contextos específicos, para objetivos específicos" (KLEIMAN, 2012, p. 18).

Soares (2012, p. 155) sugere que "se pluralize a palavra letramento e se reconheça que diferentes tecnologias de escrita criam diferentes letramentos". Mesmo enfatizando a "tecnologia da escrita" como referência ao letramento, concepção, a nosso ver, reducionista do processo, a autora reconhece, pelo menos, que não existe apenas um, mas diferentes "letramentos".

De fato, em sociedade, atuamos em diferentes contextos que, por sua vez, nos exigem o contato com várias práticas de letramento: em outras palavras, estamos sempre inseridos num vasto conjunto de letramentos. Tal pluralização favorece a origem do conceito "letramentos múltiplos", que, conforme Rojo (2012, p.13), não deve ser confundido com "multiletramentos", pois aquele se refere à multiplicidade e a variedade de práticas de letramento, enquanto este

aponta para dois tipos específicos e importantes de multiplicidade presentes em nossas sociedades, principalmente urbanas, na contemporaneidade: a multiplicidade cultural das populações e a multiplicidade semiótica de constituição dos textos por meio dos quais ela se informa e se comunica. 
Dentre os letramentos citados, para esta pesquisa, destacamos, o letramento digital (também denominado de letramento eletrônico ou letramento tecnológico) que pode ser entendido, entre outras interpretações, como condição para que se consiga usar as tecnologias digitais com competência, o que contribui para a integração e atuação do indivíduo na sociedade atual, posto que, segundo Araújo e Glotz (2009, p. 3),

quando uma pessoa não possui o domínio, ainda que mínimo, dos conhecimentos que são necessários para que possa interagir em sociedade a partir do emprego das TIC's, o não domínio das mesmas torna-se, em algumas situações, um fator de exclusão. A nossa sociedade exige que, além do domínio do ler e escrever, sejamos também letrados digitais.

Para Arcoverde (2007, p. 19), o letramento digital é "a capacidade que tem o indivíduo de responder adequadamente às demandas sociais que envolvem a utilização dos recursos tecnológicos e a escrita no meio digital". Na sua concepção,

Para interagir de modo eficiente, o usuário necessita dominar uma série de ações específicas próprias desse meio, a maioria delas envolvendo a língua escrita. Ser letrado digital representa, assim, a realização de 
modos de leitura e de escrita em situações que envolvem textos, imagens, sons, códigos variados, num novo formato, em hipertexto, tendo como suporte o ambiente digital.

O letramento digital, então, passou a ser uma exigência contemporânea, não se trata de uma escolha, mas de uma necessidade. E esse novo tempo, especialmente as últimas décadas, tem provocado mudanças comportamentais excepcionais, "dada a originalidade de suas características quando comparada com outras épocas", como argumenta Serres (2013, p. 28-29):

De fato, há algumas décadas, vejo que vivemos um período comparável ao da aurora da paideia - depois que os gregos aprenderam a escrever e a demonstrar, semelhante à Renascença, que viu surgir a imprensa e ter início o reinado do livro, mas trata-se de um período incomparável, pois, ao mesmo tempo em que essas técnicas se transformam, o corpo se metamorfoseia, o nascimento e a morte mudam, assim como o sofrimento e a cura, as profissões, o espaço, os habitats, o ser no mundo.

Em meio a essa turbulência tecnológica, é pertinente refletir sobre como a escola percebe e recebe tais transformações. Isso porque as gerações nascidas na "era digital" 
interagem, comunicam-se e aprendem de maneira diferente das nascidas na "era analógica". As motivações, interesses e percepções dos "nativos digitais" são outros, como defendem Palfrey e Gasser (2011, p. 268-269):

para as escolas se adaptarem aos hábitos dos Nativos Digitais e à maneira como eles estão processando informações, os educadores precisam aceitar que a maneira de aprender está mudando rapidamente. Antes de responder as perguntas sobre com que precisão usar as tecnologias nas escolas, é importante entender as mudanças. Para isso é necessário expandir a estrutura para toda a aprendizagem, não apenas para o tipo que acontece na sala de aula.

As mudanças são importantes, no entanto, como enfatiza Lévy (1999, p. 172), não se deve adotar essa postura de forma impositiva ou obrigatória:

não se trata aqui de usar as tecnologias a qualquer custo, mas sim de acompanhar consciente e deliberadamente uma mudança de civilização que questiona profundamente as formas institucionais, as mentalidades e a cultura dos sistemas educacionais tradicionais e sobretudo os papéis de professor e alunos. 
Seguindo essa mesma postura, Aranha (2011, p. 697) esclarece que não basta mudar os recursos tecnológicos utilizados na escola, pois, mais do que inovar as ferramentas, o que faz a diferença é o modo de agir do profissional da área da Educação:

O que ocorre, no entanto, em sala de aula, é que apesar da existência desse novo suporte digital (a tela do computador), o principal ambiente de aprendizagem continua anacrônico. Grande parte das práticas pedagógicas atuais ainda privilegia um ensino centrado apenas na transmissão/recepção de conhecimento, com ênfase na aprendizagem mediada pelo professor, na fragmentação de conteúdos em disciplinas estanques, sem considerar uma real articulação com as instâncias discursivo-culturais, e com espaços sociais por onde transitam os alunos para quem as práticas didático-pedagógicas são direcionadas.

Nessa perspectiva, uma das possibilidades para o desenvolvimento de um trabalho pedagógico é o uso de programas (softwares, aplicativos) no contexto escolar. Para Lévy (1999, p. 41),

um programa, ou software, é uma lista bastante organizada de instruções codificadas, destinadas a fazer com que um ou mais processadores 
executem uma tarefa. Através dos circuitos que comandam, os programas interpretam dados, agem sobre informações, transforma outros programas, fazem funcionar computadores e redes, acionam máquinas físicas, viajam, reproduzem-se etc.

Existem diversos tipos de programas, Behrens (2000) cita alguns: "tutoriais, aplicativos, de autoria, jogos e simulação", cada um com suas ferramentas e funções específicas, e mesmo que estes não tenham sido criados para fins educativos, eles podem ser utilizados na sala de aula, contribuindo para o desenvolvimento dos processos de ensino e de aprendizagem, a exemplo dos jogos, que estimulam o raciocínio lógico, a construção de estratégias e a habilidade de contar e operar com os símbolos matemáticos, e os editores de texto "programas que permitem escrever, ajustar, transferir, copiar, recortar, modificar, compor, decompor, gravar e imprimir todos os tipos de textos" (BEHRENS, 2000, p. 97-98).

Em suma, embora o letramento digital não tenha surgido para substituir ou competir com outros tipos de letramentos - tais como o linguístico, o literário, o escolar -, ele é um fenômeno imprescindível para a vivência na atualidade, e, por isso, deve ser cada vez mais discutido. 


\section{Delineando a proposta}

O locus escolhido para a aplicação dessa proposta, ora apresentada, foi uma escola da rede pública da cidade de Campina Grande/PB e teve como objetivo viabilizar o letramento digital no contexto escolar, promovendo, aos alunos, habilidades de leitura e escrita em suportes digitais. Como, naquele período, a escola estava sendo preparada para a sua Mostra Pedagógica, que homenageava o aniversário municipal, os alunos participantes decidiram confeccionar o folheto informativo digital a partir do tema: "Campina Grande, 150 anos: vivendo e revivendo nossa história".

Para intervir na situação, com vistas a modificar a realidade inicialmente encontrada na sala de aula, foi realizada uma pesquisa-ação. Decidimos pela aplicação das técnicas de observação participante, da aplicação do questionário de sondagem e das gravações em vídeo dos encontros realizados e, no final da proposta, fizemos a avalição da experiência, juntamente com os alunos. Contamos com participação de uma turma do $5^{\circ}$ ano do Ensino Fundamental I, com 16 alunos, que aceitaram confeccionar o folheto. Os alunos selecionados tinham idades entre 10 e 13 anos e sempre estudaram em escolas públicas. Dos 16 alunos, 05 afirmaram que dispunham, em suas residências, de tecnologias digitais (celulares, computadores, jogos eletrônicos etc), 08 já tinham tido contato com esse tipo de recurso através de outras pessoas ou de lan houses e apenas 03 não tinham tido, ainda, a oportunidade de manuseá-los. No quadro abaixo, apresentamos as etapas que foram seguidas, em sala de aula. 
Quadro 1: ações desenvolvidas na proposta pedagógica com tecnologias digitais

1- SONDAGEM: Sondar os conhecimentos dos alunos em relação ao uso das tecnologias digitais, por meio de um questionário.

2- DEMONSTRAÇÃO/EXECUÇÃO: Usar o software Publisher para a confecção do folheto informativo.

3- DIVULGAÇÃO: Imprimir e distribuir cópias da versão impressa do folheto, compartilhando a experiência com a comunidade escolar.

4- AVALIAÇÃO: Avaliar, junto aos alunos, as contribuições da proposta para o desenvolvimento da leitura e da escrita, em suportes digitais.

5- CULMINÂNCIA: Criar um produto educativo (o Guia Digital), aplicável a turmas do Ensino Fundamental da Educação Básica, para compartilhar esta experiência com professores e demais interessados, descrevendo - passo a passo - o processo de confecção de um folheto informativo, utilizando, para tanto, o software Publisher.

Para confeccionar o folheto digital, nos reuníamos, com a turma, uma vez por semana. No primeiro encontro, esclarecemos aos alunos que eles não teriam acesso à internet e, portanto, não poderiam ter acesso às redes sociais, nem usariam jogos eletrônicos durante a execução da proposta. Para nossa surpresa, esse fato não diminuiu o interesse dos alunos e foi possível contar com a participação de toda a turma até o final.

Aplicamos, então, o questionário de sondagem, contendo três perguntas, com o intuito de observar o nível da turma em relação à leitura e à escrita em suportes digitais. A primeira pergunta foi a seguinte: 1) Você acha que há alguma diferença entre realizar uma leitura no papel e realizar 
uma leitura na tela do microcomputador? Em caso afirmativo, cite alguma(s) dessa(s) diferença(s). Apenas um aluno assinalou a opção "NÃO", mas não citou a diferença, os demais marcaram "SIM". Devemos destacar duas respostas apresentadas, a saber: 1) "As diferenças são que podemos modificar o texto no computador e que no livro passamos a folha e no computador é subindo e descendo" e 2) "A diferença é que, na folha você tem que abri-la e virá-la e no computador tem uma barra para descer e no computador, quando você escreve algo errado ele já diz para corrigir". Analisando essas respostas, percebemos que os alunos tinham consciência de que não se lê no papel do mesmo modo que se lê na tela digital, comprovando-se que os diferentes suportes exigem habilidades específicas do leitor. Houve também outra resposta interessante, quando um aluno mencionou a importância do corretor de texto automático, ao dizer: "No computador, quando você escreve algo errado, ele já diz para corrigir". Esse posicionamento traz à baila a praticidade de certos aplicativos, que podem nos auxiliar na digitação de textos, além de demonstrar que o aluno percebe que a norma culta gramatical deve ser "preservada" em alguns gêneros textuais, como é o caso do folheto informativo.

A segunda pergunta tinha o propósito de saber a preferência dos alunos acerca de suportes de textos: "Você prefere ler o texto impresso ou digitalizado? Por quê?". Através das respostas, verificamos que 11 alunos optaram pelo texto digitalizado e 5 mencionaram o texto impresso. Ao serem questionados sobre o porquê dessas escolhas, enfocamos, a seguir, algumas respostas que enaltecem o suporte digital: "Porque no computador tem que desligar e no papel é só fechar.", "Porque eu consigo prestar mais atenção e ler 
mais rápido", "Porque podemos modificar o texto digitalizado, aprender coisas novas e aprender melhor os objetivos do texto" e "Porque digitalizado não precisa voltar a página, é só subir a tela". Como se nota, ao justificarem suas escolhas, os alunos apontaram características de textos que se encontram no ambiente virtual: a agilidade, a flexibilidade e as possibilidades de interação e intervenção com/sobre o texto em tela.

A terceira pergunta do questionário foi "Vocêjá realizou alguma atividade com o Software Publisher? () SIM ( )NÃO. Em caso positivo, diga para qual propósito você já tinha utilizado as ferramentas desse software. As respostas comprovaram que os alunos costumavam usar tecnologias digitais (computadores, smart phones, tablets etc.), principalmente, para acessar redes sociais ou jogos eletrônicos, e, que nunca tinham utilizado o Publisher. Assim, com auxílio de um datashow, apresentamos, à turma, as interfaces desse programa (suas ferramentas, as publicações pré-definidas e seus variados layouts), explicando, detidamente, as suas funções e como utilizá-las. Nesse momento, foi possível demonstrar que existem outras possibilidades pouco exploradas nos computadores (e em outras tecnologias digitais semelhantes), além do acesso à internet. A ideia era incentivá-los a explorar os programas disponíveis, e que são, tantas vezes, ignorados, pelo fato de não termos conhecimento de sua existência nem de sua funcionalidade.

Depois, partimos em busca de informações sobre o tema escolhido para confecção do folheto, e solicitamos que fizessem pesquisas (nas suas residências e na escola) tanto em meios impressos quantos nos digitais. De posse do material coletado, selecionamos e organizamos essas 
informações para serem inseridas no nosso folheto. Nessa etapa, foi trabalhado outro tipo de letramento, além do digital, o letramento linguístico, considerando que o folheto informativo é um gênero textual que se deve priorizar o uso da língua escrita formal.

Iniciamos, então, o trabalho operacional com o Publisher. O primeiro passo foi escolher o modelo de publicação, no caso, optamos por uma "publicação pré-definida". Esse tipo de publicação disponibiliza duas páginas para edição do texto, que correspondem, para impressão, à parte frontal e o verso de uma folha de papel A4. Dando prosseguimento, exploramos as ferramentas do aplicativo, a digitação, a diagramação do texto, layouts e design, cores, formas, estilos e tamanhos das fontes, espaços para inserir imagens entre outras mais.

Nessa etapa da proposta, além de orientarmos sobre a forma de escrita do texto (aspectos micro e macro textuais), apresentamos, aos alunos, a lgumas dicas de informática (quanto à digitação das palavras), por exemplo, a inserção de parágrafos, o uso de letras maiúsculas e minúsculas, sinais de pontuação, escolhadefontes, exclusão de palavras e outros recursos gráficos. Aqui, também tivemos a oportunidade de relacionar a proposta de intervenção pedagógica com conteúdos já estudados em sala de aula. Após a digitação de todas as informações e também da inserção das imagens correspondentes ao tema (fotos e bandeira da cidade homenageada), fizemos, juntos, a revisão final do texto. É importante mencionar que os alunos também participaram da impressão dos folhetos (alguns sequer conheciam uma impressora e nem o seu funcionamento). Por fim, imprimimos cópias do nosso folheto 
para serem distribuídas à comunidade escolar durante as visitações da Mostra Pedagógica da escola.

O processo de digitação, edição e diagramação do texto ocorreu ao longo de oito encontros em sala de aula; no entanto, os alunos sempre participaram ativamente, e, ao contemplarem a produção final do folheto, demonstraram grande satisfação pelo trabalho realizado, coletivamente. Na última página do folheto, inserimos a foto da turma, com uma breve nota explicando que os autores daquele folheto eram os próprios alunos, e listamos os nomes completos de todos os participantes. $\mathrm{O}$ resultado do folheto pode ser visualizado, em sua forma digitalizada, a seguir:

Figura 3: Folheto produzido pelos alunos (página 1/parte externa)

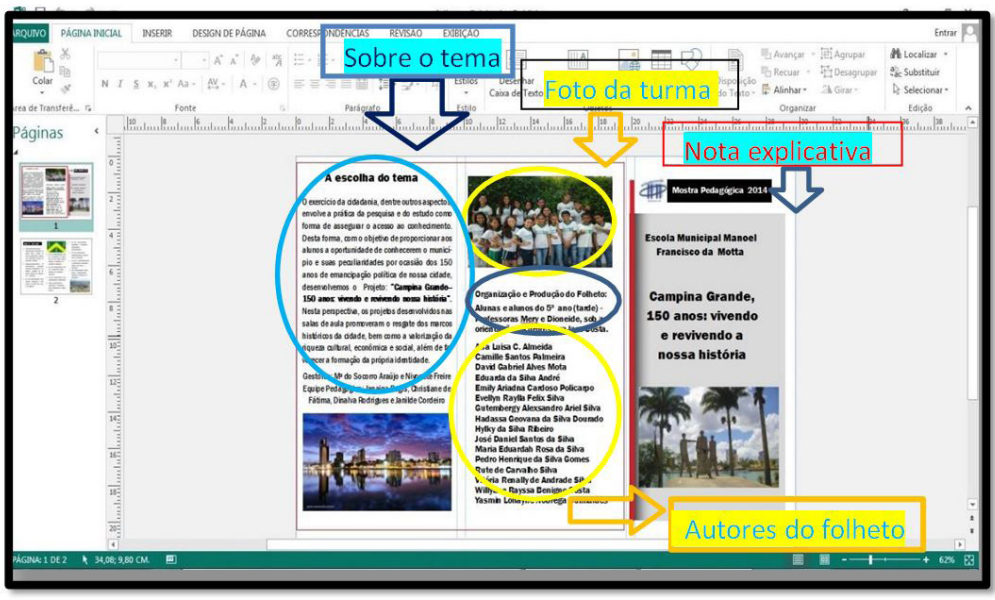


Figura 4: Folheto produzido pelos alunos (página 2/parte interna)

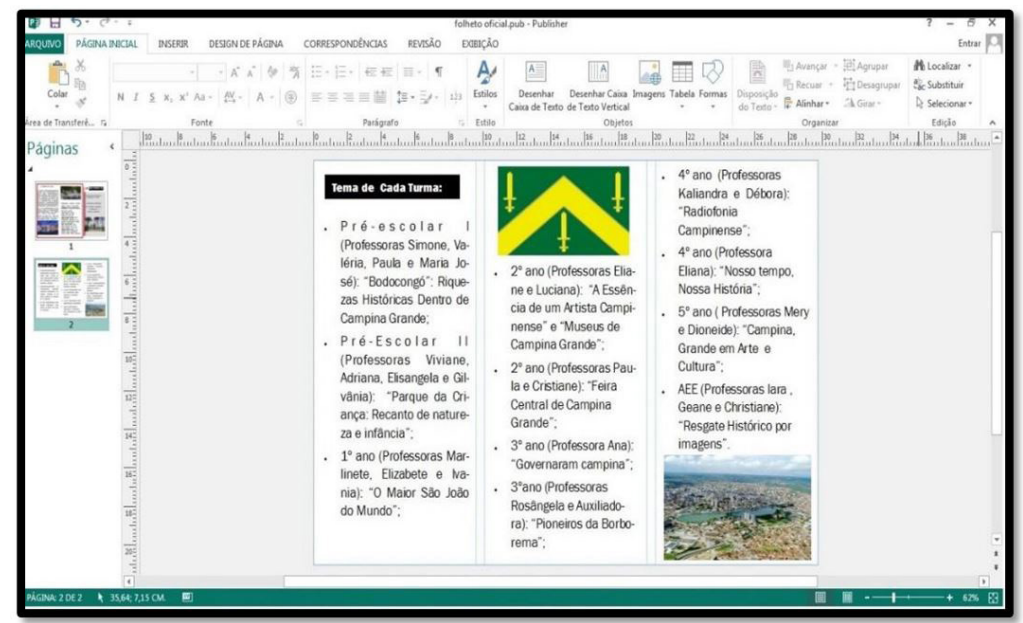

Ao final de todo o processo, reunimos a turma para avaliarmos a experiência e todos os alunos se pronunciaram positivamente. Através das imagens gravadas, é possível rever esse momento de avaliação, quando fica patente o entusiasmo dos alunos pelos conhecimentos adquiridos com o uso de um aplicativo. A interação na troca de informações e a concentração no trabalho coletivo e colaborativo foram algumas das ações capturadas por esses registros audiovisuais.

\section{Sobre o Produto Educacional: o Guia Digital}

A partir dos resultados desta experiência, confeccionamos um Guia Digital, gravado em mídia do tipo CD-R (Compact Disc-Recordable), no formato PDF (Portable Document Format). Esse produto didático 
apresenta uma estrutura textual semelhante a de um tutorial e descreve, de forma prática, como confeccionar um folheto informativo usando o Software Publisher. Este guia direciona-se a professores que se interessem em trabalhar o letramento digital na educação básica, especialmente, com alunos do Ensino Fundamental I.

Esse Guia foi elaborado mesclando a linguagem verbal e não verbal (multimodal) e encontra-se organizado em partes: "Apresentação", "O que é o Software Publisher?", "Passo a passo: como criar um folheto informativo digital, usando o Publisher", "Considerações Finais" e "Referências Consultadas". Na sua versão em PDF, o sumário é interativo, permitindo que, ao clicarmos sobre cada tópico (ou subtópico), podemos ser "encaminhados" diretamente à página correspondente àquele tópico (ou subtópico), sem necessitarmos "folhear" as páginas uma a uma.

O tópico referente à "Apresentação" traz a síntese do Guia e tece uma abordagem sobre a proposta desenvolvida, com o objetivo de inspirar outros professores a usar tecnologias digitais na sua prática cotidiana. $\mathrm{O}$ segundo tópico "O que é o Software Publisher?" faz uma breve exposição sobre esse aplicativo, qual a sua função e as possibilidades de uso como recurso pedagógico. O terceiro tópico relata o "Passo a Passo" para "criar um folheto informativo digital usando o Software Publisher". Descreve o caminho para encontrar o programa nas pastas do computador; a diferença entre software e hardware, a área de trabalho do Publisher; como escolher uma publicação para edição etc. Todas as orientações são acompanhadas de prints do programa em funcionamento, tornando a leitura, do Guia, mais dinâmica e funcional. O quarto tópico direciona-se às "Considerações finais", reforçando o 
êxito da experiência. O quinto e último tópico apresenta as "Referências Consultadas", elencando as fontes teóricas mais significativas que fundamentaram a pesquisa, e que, por sua vez, fortalecem a tese da importância da inserção de tecnologias digitais (tais como aplicativos/softwares/ programas) nos espaços escolares.

\section{E para finalizar...}

O uso de softwares como recurso pedagógico não garante, de forma automática, o desenvolvimento do letramento digital, uma vez que o sucesso de propostas dessa natureza não se sustenta pelo acesso direto às tecnologias digitais, mas pelas condições favoráveis ao uso de tais recursos.

É, pois, nesse panorama, que os professores são desafiados a desenvolver atividades que viabilizem a prática desse tipo de letramento (além de outros), e a escola não pode negligenciar essa abordagem, porque essas tecnologias fazem parte do nosso cotidiano.

A experiência descrita, aqui, comprova que é possível conciliar o poder atrativo de um programa de computador (pelos benefícios gráficos que a máquina disponibiliza instantaneamente) com o processo de ensino e aprendizagem. Cabe ainda ressaltar que, através desta proposta, a aprendizagem não se limitou a conteúdos da educação formal, mas expandiu para conhecimentos a diversas situações que os alunos vivenciarão, além dos muros da escola. 


\section{Referências}

ARANHA, Simone Dália de Gusmão. Letramento Digital e formação docente: a incorporação de tecnologias em práticas de leitura e de escrita. In: XAVIER, M. M. (Org.). Nos caminhos da Linguística Aplicada ao ensino de Português: reflexões necessárias. Campina Grande: Realize, 2011. p. 694-704.

ARAÚJO, Verônica Danieli Lima; GLOTZ, Raquel Elza Oliveira. O letramento digital enquanto instrumento de inclusão social e democratização do conhecimento: desafios atuais. Disponível em: <revistapaideia.unimesvirtual.com.br>. Acesso em 07 nov. 2017, 14:45:30.

ARCOVERDE, R. D.de L. Prática de letramento no ambiente digital. In: Revista Língua Escrita, n.2 (p.17-28), dez. 2007. Disponível em: <http://www.ceale.fae.ufmg. $\mathrm{br} / \mathrm{app} /$ webroot/files/uploads/revista $\% 20$ lingua $\% 20$ escrita/LinguaEscrita_2.pdf > Acesso em: 18 dez. 2017.

BEHRENS, Marilda Aparecida. Projetos de aprendizagem colaborativa num paradigma emergente. In: MORAN, José Manuel et. al. (Orgs.). In: Novas Tecnologias e Mediação Pedagógica. Campinas - SP: Papirus, 2000.

KLEIMAN, Ângela B. Modelos de Letramento e as Práticas de Alfabetização na Escola. In: __ . (Org.). In: Os Significados do Letramento: uma nova perspectiva sobre a prática social da escrita. 2. ed. Campinas - SP: Mercado de Letras, 2012. (1. ed. 1995). 
LÉVY, Pierre. Cibercultura. Tradução Carlos Irineu da Costa. São Paulo: Editora 34, 1999.

PALFREY, John; GASSER, Urs. Nascidos na era digital: entendendo a primeira geração de nativos digitais. Tradução Magda França Lopes. Porto Alegre: Artmed, 2011.

ROJO, Roxane Helena Rodrigues. Pedagogia dos Multiletramentos: diversidade cultural e de linguagens na escola. In: __ _ MOURA, Eduardo (Orgs.). Multiletramentos na Escola. São Paulo: Parábola Editorial, 2012.

SERRES, Michel. Polegarzinha. Rio de Janeiro: Bertrand Brasil, 2013.

SEVERINO, Antônio Joaquim. Metodologia do Trabalho Científico. 23. ed. São Paulo: Cortez, 2007.

SOARES, Magda Becker. Letramento: um tema em três gêneros. 3. ed. Belo Horizonte: Autêntica, 2009.

. Novas práticas de leitura e escrita: letramento na Cibercultura. Disponível em: < http://www.cedes.unicamp.br>. Acesso em 10 nov. 2012, 19:38:41.

STREET, Brian V. Letramentos Sociais: abordagens críticas do letramento no desenvolvimento, na etnografia e na educação. Tradução Marcos Bagno. São Paulo: Parábola, 2014. 


\title{
DIÁRIO DE CLASSE: \\ estudo das postagens de uma aluna de escola pública no Facebook
}

\author{
Joana Rodrigues Moreira-Lima ${ }^{1}$ \\ Dánie Marcelo de Jesus ${ }^{2}$
}

\section{Considerações iniciais}

O crescente acesso de usuários à internet e o surgimento de vários gêneros textuais têm possibilitado mudanças em nossas interações cotidianas. Essas transformações podem, principalmente, ser percebidas em redes sociais, em salas de bate-papo ou em fóruns de discussão

1 Professora do Instituto Federal de Mato Grosso, Campus Sinop. Mestre pelo Programa de Pós-Graduação em Estudos de Linguagem pela UFMT. Atualmente, cursa seu doutorado sob a orientação do professor Dr. Dánie Marcelo de Jesus.

2 Professor do Programa de Pós-graduação em Estudos de Linguagem e do Programa de Pós-Graduação em Estudos da Cultura ambos da UFMT. Tem experiência na área de Linguística Aplicada e Estudos de gênero atuando principalmente nos seguintes temas: discurso em contexto digital, formação de professor, LGBTTI ,diversidades e letramento crítico e inclusão. Foi vice coordenador do GT da ANPOLL ( Associação Nacional de Pós-Graduação e Pesquisa em Letras e Linguística) "Linguagem e Tecnologia" no biênio 2014 a 2016. Foi secretário da ALAB (Associação Brasileira de Linguística Aplicada) entre o biênio 2013 a 2015. É segundo secretário da ANPOLL (Associação Nacional de pós-Graduação e Pesquisa em Letras e Lingüística) entre o biênio 2017 e 2018. 
motivados pela nova ordem espacial e temporal, advinda da manifestação da cibercultura, que altera nossa subjetividade, dando lugar a um existir no mundo por meio das palavras e imagens.

Tais mudanças podem ser denotadas em comunidades virtuais a exemplo do Facebook, que, mundialmente, vem arrebatando jovens e adultos com a finalidade de promover intercâmbio entre os pares ou entre os grupos, criando redes sociais que ligam pessoas com interesses comuns. Para isso, os participantes criam comunidades em torno de diversos temas, intentando reunir o maior número de pessoas que possuam afinidade com o assunto em apreço. Os participantes apresentam suas opiniões sobre determinado assunto. Dessa maneira, as comunidades do Facebook acabam se estruturando, assentadas em diferentes ideologias.

De conseguinte, torna-se ambiente propício à investigação de pesquisadores preocupados com a dinamicidade do ambiente digital e com suas consequências sociais. Essas comunidades também são reveladoras da forma como certos segmentos da sociedade brasileira interagem com determinados temas, sobrelevando a escola. Portanto, ao compreendermos como esses usuários representam certos temas, podemos ter pistas de modo como algumas ideologias são constituídas no pensamento social.

Diante disso, procuramos investigar uma comunidade em particular, "Diário de Classe" -, pertencente a uma aluna do ensino fundamental de uma escola pública de Santa Catarina. Essa comunidade se estrutura em torno do sistema educacional e de suas observações e críticas a esse contexto. Nesse rumo, buscamos entender a materialidade discursiva dessa internauta no âmbito da escola pública. 
A escolha dessa comunidade organizada por uma adolescente se deu por sua popularidade nas redes sociais, tornando-se, sua autora, celebridade midiática, sendo convidada para debater, em diversos eventos no Brasil, a respeito de assuntos como educação, juventude e tecnologia. Criou uma organização não governamental (ONG) com dizeres que anseiam por melhorar a educação do país e, recentemente, publicou um livro desfiando sua experiência vivenciada com o "Diário de Classe". Não bastasse, a ideia de sua comunidade foi replicada por diferentes jovens brasileiros.

Este artigo objetiva, portanto, compreender postagens de uma adolescente em uma comunidade na rede social Facebook. Essas investigações permeiam uma série de trabalhos de caráter interpretativo (ZUBLER, 2014; XAVIER, 2014; ALVES, 2014) a respeito dos efeitos sociais do universo digital na educação, cujo foco é entender como práticas sociais - entendidas como toda experiência social que um sujeito vivencia em suas interações cotidianas -, no ciberespaço, podem edificar enunciados à volta da escola.

Para dar conta desta empreitada, apresentamos, inicialmente, algumas das concepções teóricas oriundas do Estudo do Discurso, tais como a noção de discurso, ideologia, prática discursiva e poder. Já num segundo momento, discutimos o contexto da pesquisa e a análise dos dados. Finalmente, explanamos algumas reflexões que tangenciam esta investigação. 


\section{Discurso e poder}

Não podemos considerar o discurso dissociado de práticas de poder. De acordo com Fairclough (2001, p. 91), o discurso é "um modo de ação, uma forma em que as pessoas podem agir sobre o mundo e especialmente sobre os outros, como também um modo de representação".

Nesse sentido, ao agir sobre o mundo e sobre os outros, o discurso constitui uma das formas de poder. Foucault (1970/2012), a respeito dessa questão, advoga que o discurso não é simplesmente aquilo que traduz as lutas ou os sistemas de dominação, mas aquilo por que se luta, pelo qual se bate, o poder de que nos queremos apoderar.

Portanto, o poder não pode ser visto apenas como algo negativo, mas algo entremeado nos discursos da sociedade, por meio de relações inerentes a cada contexto específico. Isso infere que as práticas discursivas não são neutras, dado que os sujeitos materializam seus discursos para exercer seus diferentes papéis sociais.

Para que esse poder se materialize com sucesso, Fairclough (2001) assevera ser importante que os mecanismos de dominação não sejam evidentes. Essa percepção remete ao fato de que o poder pode ser camuflado, uma vez que ele pode estar embutido em manifestações, cujos argumentos giram em torno de conquistas por interesses comuns (DIJK, 2008).

Para tanto, a linguagem retrata importante componente para as práticas discursivas. No entanto, estas transcendem a língua e suas estruturas quando vistas como práticas sociais. Por isso, Fairclough (2001), ao tecer ênfase sobre o discurso, expressa que este depende da linguagem como prática, e não como atividade puramente 
individual, ou reflexo de variáveis situacionais. Entender o discurso como prática social pressupõe que o poder não é situado em apenas um sujeito ou em uma instituição, como se pensa. O poder é distribuído entre os sujeitos sociais.

Como bem define Foucault (2012), o discurso, como prática de poder, é uma maquinaria complexa e contraditória. Entende-se que ora age com sistemas de exclusão e dominação, ora com vontade de igualdade e democracia. Fairclough (2001), por seu turno, acredita que o discurso contribui para compor as identidades dos sujeitos e suas relações sociais, bem como suas representações sobre o mundo e seus conhecimentos. Assim, esse autor focaliza a relação de poder e a ideologia, constitutivas das dimensões sociais do conhecimento, das relações e da identidade social.

A ideologia, ainda na concepção de Fairclough (2001), está sedimentada em três proposições. A primeira sustenta que a ideologia tem sua existência própria nas práticas das instituições e, por isso, possibilita a investigação das práticas discursivas como formas materiais de ideologia. Para a segunda, a ideologia perpassa o sujeito, constituindo-o. A terceira proposição evidencia que os aparelhos ideológicos do Estado - escola, mídia, igreja, família, etc. - são demarcadores da luta de classe e, em consequência, das lutas no interior do discurso. Partindo dessas três proposições, Fairclough (2001, p. 117) define assim ideologia nestes termos:

significações/construções da realidade (o mundo físico, as relações sociais, as identidades sociais) que são construídas em várias dimensões das formas/ 
sentidos das práticas discursivas e que contribuem para a produção, para a reprodução ou para a transformação das relações de dominação.

As "práticas discursivas" constituem a dimensão do uso da linguagem que engloba os processos de produção, distribuição e consumo dos textos, variando de acordo com os tipos de discursos e fatores sociais. As práticas discursivas guardam um caráter convencional que reedita as condições de produção da sociedade como valores, comportamentos e crenças sociais do mundo capitalista, compondo uma complexa teia de luta de poder, gerador de ideologias diversas que se autoalimentam. Para ele, as práticas discursivas, além do processo convencional ou reprodutor, trazem, em seu interior, a capacidade de transformar as relações de poder com suas respectivas ideologias.

\section{Contexto da pesquisa}

A administradora da página ${ }^{3}$ "Diário de classe", no alto de seus treze anos, principiou suas postagens estudante que era do ensino fundamental de uma escola pública de Florianópolis, em Santa Catarina - e criou sua

3 Em $1^{\circ}$ de maio de 2014, a comunidade possuía 626 mil curtidas. Embora os comentários existentes na comunidade, por parte dessas pessoas, não façam parte deste estudo, percebemos que a maioria dos comentários é de apoio aos discursos da discente, nos quais são observados discursos semelhantes aos dela, referentes à escola. 
página inspirada em uma menina escocesa. Sua postagem centra o foco nos problemas escolares e em assuntos correlacionados com a situação social do país.

A imagem inicial da página pesquisada é representada por algo que nos faz lembrar a figura de um quadro escolar pintado pela cor vermelha, com a função de despertar a atenção aos leitores. Para reforçar essa ideia, as palavras "Diário de Classe", são bordadas com pedaços de giz aludindo às práticas escolares convencionais. A seguir, em destaque a palavra "verdade" sugerindo que, nessa comunidade, o leitor encontrará uma sistemática discussão, mediada pelo diário, sobre a escola.

No respeitante à estrutura da comunidade em destaque, acrescentamos que esse ambiente é composto pela multimodalidade - linguagem verbal e não verbal. A estudante usa bastante texto em suas postagens, contudo as imagens e vídeos aparecem com relevância. Observamos que o celular se tornou instrumento de grande importância para as práticas cotidianas dessa aluna. Consequência disso: a maioria dos registros feitos deriva do próprio aparelho da discente. Em meio às suas postagens, ora surgem registros de fotos das merendas que são servidas diariamente, ora aparecem imagens de problemas estruturais existentes na escola. 


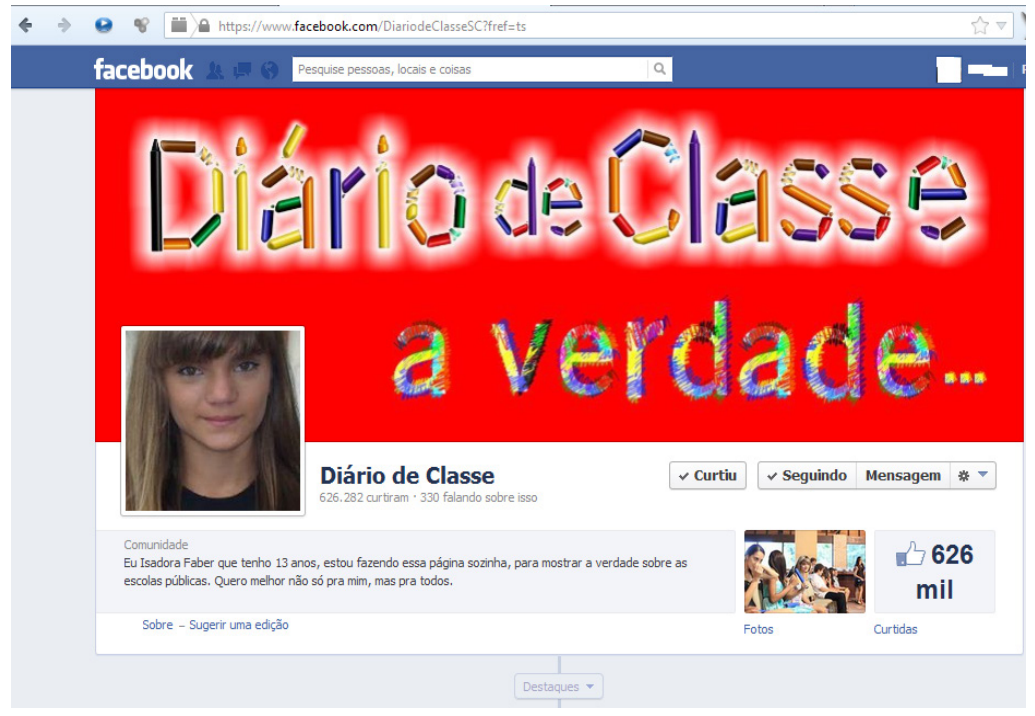

Figura 1: Imagem da página inicial de Diário de Classe

Para compreendermos o discurso sobre a escola pública que ela se afilia em suas postagens, seguimos alguns critérios com vista à sistematização dos dados. Neste intuito, 182 postagens foram analisadas entre julho de 2012 a outubro de 2013, ressaltando um total de 124 foi descartado por repetir seus discursos nas 58 consideradas para tal estudo.

Nessa etapa, os dados foram copiados e colados em páginas de editor de texto com a finalidade de abstrair um panorama e apreender as categorias de análise. Com o objetivo de sistematizar a análise dos dados, decidimos utilizar cores diversas a fim de detectar dados recursivos e significativos para o estudo. Nesse caminho, um recorte de dados foi inspirado em King e Horrocks (2010), realizado por meio da redução do corpus, em forma de frases 
curtas, ideias-chave e conceitos empregados pela aluna. Em seguida, os dados passaram por novo crivo, objetivando identificar os temas mais frequentes.

Neste trabalho, o termo temas implica traços recorrentes e distintos pinçados dos relatos dos participantes, relevantes aos olhos do pesquisador (KING; HORROCKS, 2010). Em razão da natureza desta publicação, traremos, como exemplificador dessa investigação, dois temas: $A$ escola como local da ordem e punição, e a escola ideal.

\section{A análise dos dados}

\section{A escola como local da ordem e punição}

Como retratam diversos pesquisadores (SIBILIA, 2012; FOUCAULT, 1970/2012), a verdade e a punição constituem a maneira de legitimar o discurso, como prática de poder disciplinar existente em âmbito escolar, para manter os corpos dóceis. Diante disso, percebe-se que a escola, em algumas circunstâncias, está situada entre esses dois habitus - a verdade e a punição -, pelos quais seus membros delineiam sua conduta.

A escola ainda busca se pautar em princípios normalizadores com a finalidade de disciplinar os sujeitos escolares. Isso pode ser visto nos excertos a seguir, nos quais a estudante parece reproduzir o redundante discurso hegemônico sobre a escola. 


\section{Excerto 1}

Achei legal...

\section{Ensinam pra gente que a verdade é boa, mas quando dizemos a verdade, todo mundo se ofende.}

Figura 2: Diário de Classe, 12-9-2012

Como se verifica no excerto 1 , a imagem marca um contraste entre as cores preta e branca para realçar o enunciado a propósito da questão relativa à verdade. Haja vista que esta parece depender de quem e de onde vem, para ser legitimada. A imagem selecionada pela estudante tende a questionar os sujeitos escolares que sugerem estar em uma posição privilegiada (professores, direção, coordenação). Esta escolha denota que a escola da discente, como outras instituições sociais - a igreja, órgãos que primam pela justiça, etc. -, também defende, em seus discursos, a primazia pela "verdade", como forma de confissão dos atos, supostamente errados, perante a sociedade. Porém, a verdade advinda destes lócus geralmente obedece a uma hierarquia, em que seu detentor quase sempre é quem se intitula representante soberano.

Ressalte-se que, na atualidade, em que os sujeitos tendem a não obedecer uma única norma, a verdade se torna contingente. Uma vez que esta pode ser certa para alguém, o outro pode com ela não concordar. No entanto, comumente se observa que muitos sujeitos passam boa parte de seu tempo requisitando "sua verdade" ao outro. Se, de alguma maneira, o detentor da verdade for questionado, 
poderão surgir conflitos entre os pares, e até mesmo desestabilizar o lócus de onde ela veio. (FAIRCLOUGH, 2001)

O enunciado acima encarta a concepção binária de que a "verdade é boa", aparentando que isso é o que se espera do outro. Por outro lado, a generalização "todo mundo se ofende" demonstra uma oposição do que era para ser "bom". Talvez, para o contexto mencionado pela estudante, a palavra "gente", anteposta à oração "que a verdade é boa", infira tratar-se dos alunos, e "todo mundo" supõe referir a seus professores. Nesta interpretação, o enunciado atende a seguinte proposição: “Ensinam aos alunos que a verdade é boa, mas, quando dizemos a verdade, os professores se ofendem".

A estudante figura questionar que a verdade não é para todos, nem pertence a todos, depende de quem e de onde é proferida. A verdade professada pelos docentes se inclina a ser boa, mas, ao ser tomada por alunos, para questionar seus superiores, não tem a mesma validade e passa a traduzir algo errado que pode culminar em punição.

Logo em seguida, emerge um exemplo em que a estudante se apropria do discurso da verdade, tomando-o para si. Contanto, a verdade da estudante não aparenta ser a mesma de sua professora.

\section{Excerto 2}

Hoje minha mãe teve que ir ao fórum para uma audiência conciliatória que uma professora auxiliar fez um BO contra ela por injúria. Ficou brava com os comentários do post do dia 20-08 que nas aulas dela não rendiam nada. É verdade, ela dá um texto qualquer e pede pra gente responder duas perguntas, depois a gente fica jogando. 
Se não tem formação para trabalhar com alunos de $7^{\circ}$ série, o que esta fazendo lá? Na audiência, não demorou 15 minutos uma vez que ela não quis nenhuma conciliação, nenhuma retratação, apenas quis seguir em frente com processo crime. Tudo bem, fazer o que, pena que ela apagou os posts dela, mas quem quiser olhar, sobraram as respostas dadas a ela nos comentários.

Diário de Classe, 10-10-2012

A professora, sentindo-se agredida com as postagens da discente, procura leis/justiça para punir a mãe, responsável que é pela educação da filha. Isto reafirma o que Fairclough (2001) insinua, no sentido de que a verdade é contingente, pois aqui parece obedecer a uma hierarquia, haja vista que a palavra "injúria" comprova que a verdade da aluna não era a verdade da professora. Tal fato resultou em conflitos que levaram a docente a tomar atitudes drásticas, sem o intuito de reconciliar-se.

Neste exemplo, subentende-se que a estudante não concorda com a punição proveniente da professora, porque entende que tem razão sobre o fato (É verdade, ela dá um texto qualquer e pede pra gente responder duas perguntas, depois a gente fica jogando). Isso ressalta que os preceitos de punição e de verdade são contraditórios, desconstituídos de validade para aqueles que estão sob este jugo.

Para enfatizar a escola como local de punição, a discente expõe, posteriormente, uma imagem que alude ao fato de que esta instituição educacional guarda semelhanças com confinamentos (SIBILIA, 2012) e que sua função não é, prioritariamente, a aprendizagem. 


\section{Excerto 3}

O portão da escola, os problemas começam na PORTA DE ENTRADA.

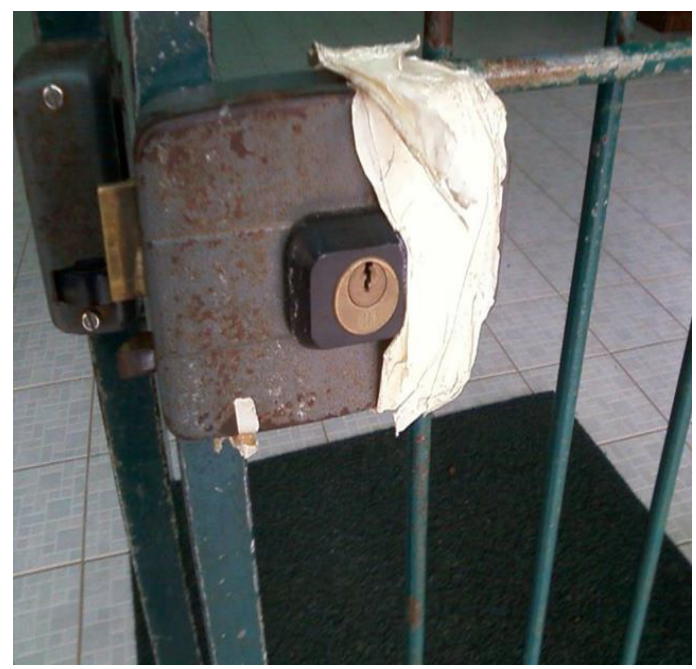

Figura 3: Portão da escola

Diário de Classe, 11-7-2012

Essa imagem do portão sugere uma analogia do que a escola pode representar para alguns estudantes. O que a discente quis registrar, talvez inconscientemente, não é somente a questão de exigir um portão novo para sua escola.

Com base em Foucault (1970/2012), algumas características da escola são peculiares às estruturas arquitetônicas das prisões, cujas salas são construídas lado a lado sem comunicação, janelas com grades, refeitório comunitário, muros altos, portões e vigias. O espaço interno das salas é marcado por carteiras enfileiradas. Já o aluno, uniformizado, se vê sujeito à autoridade do professor. $\mathrm{O}$ 
disciplinamento é refletido pela individualização dos alunos engajados em um espaço quadriculado, em que a postura, os gestos e a produção são monitorados ou vigiados constantemente.

Partindo dessa premissa, a discussão evocada entra em consonância com o que esta aluna, em vários aspectos, forceja por questionar a respeito de sua escola, como espaço de verdade e punição. Ao apresentar o portão de sua escola, que faz alusão ao da prisão, despontam indícios de que a escola, tal como a prisão, agasalha princípios dogmáticos de justiça, expressos pelo desejo de "verdade", que esta pesquisa mostra ser contingentes. Afinal, a verdade doutrinada não pode ser requisitada para quem a profere. Isso abre ensejo a questionarmos se a escola ainda deve ser construída em torno dos pressupostos de verdade?

Por via de consequência, a simbologia do portão, presente nesta figura, remete ao pensamento de que a "PORTA DE ENTRADA" da escola está em concordância com os portões da prisão, os quais também evidenciam seus problemas na porta de entrada, mostrando que ali, naquele espaço, também deve existir vigilância como mecanismo de punição. Ser disciplinado é a forma normalizadora de ser cidadão. Em contrapartida, se as normas não forem obedecidas, cabe ao sujeito transgressor receber a punição.

Entretanto, é válido discutir que o aluno que é educado nestes preceitos disciplinares tende a reproduzir as ações de seu mestre. Isso vem aludir ao pensamento de Fairclough (2001) em relação à ideologia e a seus efeitos de sentido. Por assim ser, no excerto 4, a discente comprova, apesar de contraditoriedades, que está assumindo 
a mesma postura e discurso da escola, conforme se aclara a seguir.

\section{Excerto 4}

Essa página não é contra a escola só que bem agora esta a eleição e estamos mostrando a verdade sobre escolas publicas que não são cenários queremos saber quem vai melhorar isso, quem vai ser responsabilizar de ir ate a escola e cobrar, com que arrume e com que os alunos tenham atenção queremos punição "coisa que é difícil" como falamos da menina que levou a arma. Porque ficar brabo com a verdade estamos querendo o que já era pra ser exigido não por alunos, mais SIM chegou ao ponto que alunas da escola estão exigindo a punição, pra ver onde chegou a coisa.

Diário de Classe, 30-7- 2012

Neste contexto, a estudante parece se colocar, primeiramente, como defensora da escola, cuja função é mostrar a verdade em tempos de eleição. Depois, questiona a ineficiência de sua escola por não oferecer um local adequado para estudar. Para tanto, solicita melhores condições no ambiente em torno, com vista ao comportamento dos discentes. Fica nítida sua posição com referência às palavras "atenção e punição", por meio das quais se justifica a existência do "Diário de Classe", para chamar atenção e mostrar a "verdade", reforçando hábitos disciplinares.

$\mathrm{O}$ advérbio de afirmação "SIM", em destaque, evidencia a desconstrução do papel da escola, por acentuar que, naquele momento, a função de exigir "melhorias e punição" seja competência de alunos, antes de ser da instituição educacional. O discurso desta aluna se deve ao fato de 
que os sujeitos desta geração são performáticos, não possuem apenas uma identidade, mas várias identificações (FAIRCLOUGH, 2001). Esta estudante dá a impressão de se dividir entre o desejo de responder o imaginário de aluna que atende aos pressupostos escolares e o papel de questionadora da escola, que se inclina a tomar o discurso escolar para si. Por sua vez, parece reproduzi-lo sustentado, em muitos aspectos, sob os pilares disciplinares. (SIBILLA, 2012)

Nesse rumo, esta discente, sujeito desta formação educacional, agora também se sente no direito de julgar o que é certo ou errado em sua própria escola e exigir punição daqueles que ela supõe serem culpados. Contudo, paira a dúvida de que a discente não concorda muito com essa atribuição, tomada por ela (aluna), quando deixa implícito que tal está sucedendo em razão de falta de atitude escolar, dado que alunos estão exercendo um papel que não lhes compete. É notório que a estudante se situe como alguém que se apropriou das práticas adotadas pela escola. Isto se confirma nos enunciados, "chegou ao ponto que alunas da escola estão exigindo a punição, pra ver onde chegou a coisa".(Grifo nosso). O termo "alunas", a que se refere, subentende tratar-se dela e de outra colega que, inicialmente, estava dando apoio à sua comunidade.

No excerto 5, a estudante sustenta que sua professora parece tentar coagir não somente a discente, mas também os demais estudantes, como se verifica na sequência:

\section{Excerto 5}

Hoje a professora de português Queila, preparou uma aula pra me "humilhar" na frente dos meus colegas, a aula falava sobre política e internet, ela falava que 
ninguém podia falar da vida dos professores, porque nós podíamos ter feito muitas coisas erradas pra eles odiarem e etc. Eu e acho que a maioria dos meus colegas entenderam o recado "pra mim". Além disso quando vou até o refeitório as cozinheiras, começam a falar de mim, na minha frente e rir, eu e a Melina (minha colega) fomos reclamar com a diretora, então ela disse que eu tenho que aguentar as consequências e que a partir de agora seria assim com todos, não resolveu o problema. Confesso que fiquei muito triste ...

Diário de Classe, 24-8- 2012

Neste enunciado, a estudante assinala que sua comunidade escolar não é, totalmente, incomplacente às normas, ao modo como com ela já expôs, em outra passagem, a respeito de fatos sobre os quais a escola parecia não se manifestar. Neste exposto, a discente expressa toda uma discursividade (FAIRCLOUGH, 2001) para mostrar que ela é a vítima das injustiças escolares. Este fato retoma uma discussão a que já se fez alusão, no tocante ao fato de a escola assemelhar-se a uma prisão. Afinal ela representa o poder disciplinador (FOUCAULT, 1970/2012), onde os transgressores seriam punidos por seus atos. Embora assim, parece ser o local mais envolto por injustiças sociais.

Em sua visão, alguns professores sabem punir aqueles que desejam tomar-lhe a voz. Para isso, a professora preparou a aula para manifestar-se sobre a internet. Supõe que esta explanação tenha sido com o intuito de estabelecer um controle na sala de aula, exasperar uma forma de coerção, para que outros alunos, ao verem os exemplos, não utilizassem a internet para a mesma finalidade. Práticas como estas nos lembram Foucault (1998), que discute sobre os sujeitos excluídos da sociedade (loucos, criminosos), por 
meio dos quais seu discurso era invalidado para enfatizar o saber dos "normais". Diferentemente ocorria com os intelectuais, que traziam em seu discurso a verdade para legitimar seus saberes.

A soberania da instituição escolar se reforça quando a aluna argumenta que não foi somente sua professora que tomou esta postura, considerada coercitiva/silenciadora. Os demais membros escolares (funcionários e diretora) também estão contra a desestabilização escolar, provocada pela estudante. Para isso, na voz da diretora advém o discurso de "aguentar as consequências", endereçado a quem inflige as regras. Mais uma vez, este discurso remete à ideia de justiça/punição, pois, se errou/transgrediu, de algum jeito, deve pagar por seus atos.

Nesse viés, as punições e as práticas de silenciamento parecem não ser mais suficientes, no atual período histórico. As tecnologias digitais trouxeram nova forma de exibição. Quando surgem os discursos dos silenciados, tende a ocorrer uma mistura de discursos, em meio aos quais o poder se torna mais distribuído (FOUCAULT, 1998). A escola precisa pensar em tais questões, haja vista que talvez esta esteja adotando práticas punitivas que ultrapassam as normas escolares, em razão da transposição da sala de aula para as redes sociais, tornando pública qualquer menção que o estudante faz em referência ao professor.

Mas como a escola precisa agir ante estas instabilidades que se instauram na escola?

Sobre esse assunto, continuemos os debates, deixando nítida a posição de alguns docentes acerca da exposição de suas aulas por parte de estudantes, em redes sociais, conforme se vê a seguir: 


\section{Excerto 6}

Hoje eu e meu pai fomos na delegacia porque minha professora de português fez um BO de calunia e difamação. Eu fui, nunca tinha entrado numa delegacia antes, mas lá dentro todos me trataram muito bem mesmo. Estranhei pois para mim o assunto já estava encerrado desde o início do mês quando ela me pediu desculpas, eu aceitei e publiquei, está aqui até agora. Como vocês podem ver, não é fácil manter o Diário no ar.

Diário de Classe,18-9- 2012

Neste exemplo, no respeitante ao excerto 6, não convém discutir se a professora está certa ou errada, pois o que se analisa é o discurso da aluna e, realmente, não se sabe como se deram os fatos que culminaram em tais atitudes. Contudo, pelo que se apresenta na postagem, tende a reiterar as discussões aludidas em outro passo. A estudante comprova que sua desobediência às normas escolares resultou em uma punição, que agora não diz respeito somente à escola.

A professora, percebendo que as regras escolares seriam afáveis para puni-la, procurou outras instituições disciplinares para silenciá-la. Com esse mecanismo de poder (FOUCALT, 1998), a docente quis mostrar que a escola, incompetente para impor-lhe o silêncio, recorria ao sistema judiciário para esboçar tal corretivo tendente a voltar à normalidade. Parece existir, neste momento, uma disputa de poder, em que a docente quis patentear que sua voz ainda prevalece e, se a discente foi capaz de se manifestar contra seu discurso, punições mais severas precisariam ocorrer para reverenciar a palavra predominante. 
Em contrapartida, a estudante questiona que as normas parecem ser somente para o discente, pois esta professora não seguiu as regras escolares, conforme evidencia o regimento a seguir:

\section{Excerto 7}

Na última aula, minha professora de português sugeriu que todos os alunos lessem o regimento interno questões 8 e 9 (me parece censura), eu estava olhando em casa e lendo inteiro, então bem abaixo do que ela falou estava uma parte para professores "Sócia Educativa" dizendo que quando algo acontece algo com aluno, tem que encaminhar o caso para MPSC, não sofri nenhuma medida sócia educativa, fui parar direto na delegacia mesmo. Acho que ela deveria ler o regimento também.

Diário de Classe,18-9- 2012

No excerto 7, a discente comprova que a escola possui o regimento que precisa ser obedecido pelo aluno. Todavia, a aluna argumenta que, no regimento, também há alguns critérios para orientação dos docentes, porém sua professora não seguiu as regras corretamente e, de pronto, resolveu tomar providências mais rigorosas. Este ato da docente reflete que, mesmo a escola tendo suas medidas, estas não são consideradas suficientes pelos professores para ampará-los quando se sentem lesados por alguma atitude de alunos. A ilusão de muitos é que as instituições encarregadas de moldar os sujeitos (manicômio, prisão, justiça) consigam êxito para reprimir-lhes os corpos. No entanto, Foucault (1998) exemplifica com o sistema prisional, assegurando que este não mais desempenha sua função de educar e docilizar os corpos. 
Esse insucesso em projetos que tendem a modelar os sujeitos pode decorrer da imposição de regras sem negociações. É possível discutir, no caso da escola, que, quando se vive sob a pressão dela, a tendência de alguns é querer quebrar as normas impostas, de cuja elaboração não tiveram participação. Fica explícito, na parte destacada do regimento, que o objetivo da docente era usar métodos coercitivos para calar os alunos, consistindo em violência simbólica (BOURDIEU, 1989). Com esta prática, a professora não demonstrou interesse em que os discentes conhecessem ou debatessem todo o regimento, antes que pudessem apenas conhecer a parte que era conveniente a ela.

Pode ser possível que as leis estabelecidas por determinadas escolas já não estejam dando conta de atender o público escolar porque ainda busca desconsiderar a voz do estudante. Talvez tenha chegado a hora de ambos (aluno e professor) dialogarem e estabelecerem suas regras de forma coletiva, sem impor hierarquias aleatórias. Tapscott (2010, p. 159) aduz que "os professores precisam sair do palco e começar a ouvir e a conversar, em vez de apenas falar". Esta afirmação pressupõe que alguns professores não podem ficar tão distantes de seus alunos, mantendo posições assimétricas que parecem não mais combinar com a atualidade. A escola precisa entender que não é constituída apenas por docentes, mas por alunos que possuem anseios próprios. Portanto, nada é mais coerente que as normas sejam negociadas entre seus membros.

Para dar continuidade sobre o discurso da discente do "Diário de Classe", enfatizo, na sequência, a próxima categoria, que encarta alguns debates significativos para 
indicar como esta estudante tende a construir seu discurso, na página do Facebook, em torno da escola ideal.

\section{A escola ideal}

Ao abrir nossas interpretações, percebemos que os discursos existentes nessa categoria estão intimamente ligados a uma escola idealizada para contemplar algumas visões a respeito de como deveria ser o processo de ensino e de aprendizagem e a postura dos professores dele. $\mathrm{Na}$ mesma esteira, a estrutura física ideal para a escola e a solicitação para que a comunidade escolar, principalmente os pais de alunos, mude seu perfil, assentado na passividade, passando a exigir uma escola ideal para seus filhos.

\section{Excerto 8}

Hoje tivemos uma reunião, com a nova professora de matemática Sandra, ela convocou pais e alunos, para irem até lá conhecê-la, fiquei muito satisfeita com ela, parece muito responsável, acho que realmente vamos começar a aprender de verdade, estou muito feliz, espero que todos meus colegas, colaborem.

Diário de Classe, 03-9-2012

No excerto 8, intuímos que a aluna aparenta satisfação com sua nova professora de matemática porque convocou pais e alunos para conhecê-la. Observamos, em um primeiro momento, que a discente promoveu juízos de valor a respeito da professora, esclarecendo que "parece muito responsável". Ao inferir uma qualidade 
para a professora, deduz que, para uma escola ser ideal, necessita ter professores responsáveis.

Logo em seguida, conclama que "acho que realmente vamos começar a aprender de verdade". Desperta-nos a atenção o fato de que, apenas no dia 3 de setembro de 2012, os alunos comecem "aprender de verdade". Assim, a discente parece insinuar que não houvera aprendizagem durante os períodos anteriores. Porém, para que as aulas se tornem satisfatórias, a discente pede a colaboração de seus colegas "espero que todos meus colegas, colaborem". Essa afirmação enuncia que, apesar de ter ela posto a responsabilidade do processo de ensino/aprendizagem nas mãos do professor, este, de sua parte, não é o centro deste processo, pois há os alunos que podem colaborar, ou não, para que haja sucesso.

Portanto, no discurso da discente se afigura que a escola ideal se consolida por meio da primeira opção em que o professor se apresenta como o detentor do conhecimento, e o aluno o receptor, assim como podemos observar a seguir:

\section{Excerto 9}

Hoje quero falar sobre a mudança de comportamento dentro das salas de aula. Na minha aula são 37 alunos. Na maioria das aulas, a turma se comporta direito, faz silêncio, todos podem aprender. Mas em determinada matéria, infelizmente, não é possível aprender. O professor perdeu totalmente o controle da turma. Não consegue ensinar nada, uma bagunça, um barulho, todos falando ao mesmo tempo, fazendo de tudo. Este ano tenho 8 professores, apenas em uma matéria acontece isso. Os alunos são os mesmos, então, o que acontece? Claro que os 
alunos têm sua parcela de culpa, mas e o professor? Será que não tem culpa também? Acho que não adianta o professor saber muito, ter mestrado, se não tem condições de manter a disciplina para ensinar. Deveria ter alguém que assistisse a umas aulas para poder avaliar o potencial do professor. Não é justo com os alunos que querem aprender.

Diário de Classe, 2-4-2013)

A estudante transpira ser defensora de uma escola em que, primeiramente, prevaleça a disciplina "Na maioria das aulas, a turma se comporta direito, faz silêncio, todos podem aprender". Averiguamos, em seus discursos finais, que a escola ideal seja aquela construída de acordo com as conjeturas iluministas (SIBILIA, 2012), sendo a precursora da razão. Papel do aluno é apenas o de receptor do conhecimento legitimado pela instituição escolar, por meio de seus mestres.

Neste excerto, a aluna tece um comparativo entre a aula de alguns professores "Este ano tenho 8 professores, apenas em uma matéria acontece isso". Revelando que a estudante almeja uma aula em que predomine o silêncio, expressa que o professor não consegue ensinar por causa da bagunça e do barulho. A aluna faz referência aos alunos, mas acaba responsabilizando o professor pelos acontecimentos na sala de aula "mas e o professor? Será que não tem culpa também?". Outra evidência apresentada é que a escola ideal não precisa ter professor apenas qualificado. Ela esclarece: antes de o profissional ser qualificado, este precisa saber disciplinar seus alunos "acho que não adianta o professor saber muito, ter mestrado, se não tem condições de manter a disciplina para ensinar". 
Nesse sentido, concluímos que a escola ideal, desenhada nos discursos desta discente, aporta sinais de que o professor é o protagonista em uma sala de aula e, se este não conseguir disciplinar seus alunos, de nada vale seu conhecimento intelectual para contribuir com seus estudantes. E, quando ela se refere à colaboração dos discentes, interpretamos que essa palavra, neste contexto, parece ser sinônimo de silêncio.

Notamos que a discente reforça as mesmas idealizações nas estruturas escolares que tendem a ser voltadas para o disciplinamento dos alunos, conforme veremos nesta passagem.

\section{Excerto 10}

Hoje pra quem não sabe, foi o meu primeiro dia de aula, a escola está linda. As salas estão pintadas, ventiladores são novos, o muro da frente pintado, gradearam a entrada, ou seja, a escola está novinha. Agora os alunos tem que fazer sua parte para conservar. (não tirei foto da frente mas amanhã eu tiro ). Quero aproveitar para agradecer a todos vocês que me apoiam, é muito importante para me incentivar a continuar, pois tem muitas escolas que precisam ser reformadas. Obrigada.

Diário de Classe, 18-2-2013

Conforme visto neste excerto é compreensível que alunos desejam uma escola com estrutura física melhor "As salas estão pintadas, ventiladores são novos". Todavia, percebemos que o ideal de escola construída no imaginário tende a cercadas de grades: "gradearam a entrada". Uma escola ideal para a contemporaneidade poderia ser aquela em que as estruturas fossem reinventadas para romper 
os muros da escola, onde os alunos não precisassem ficar sentados, enfileirados, ouvindo apenas o professor falar. Antes, que fosse o sentido da palavra "colaboração" posto em prática para que alunos e professores arquitetassem uma escola menos autoritária, com divisão de poder mais interativa.

Em arremate, entendemos que o pedido de apoio desta discente se resume apenas no consertar/reformar o que já existe, mas não em mudanças que possam ofertar outros sentidos para a educação da atualidade.

$\mathrm{O}$ discurso posterior insere alguns questionamentos e afirmações sobre o papel da sociedade diante dos acontecimentos do país. Porém, a discente exterioriza algumas palavras que nos indicam o que seria uma escola ideal para esta aluna, e o que ela entende ser ideal para outros sujeitos sociais.

\section{Excerto 11}

Dia 16 agora vou fazer 14 anos. Neste último ano foi o que mais aprendi, não só na escola, mas principalmente por tudo que passei, conheci muitas pessoas, troquei muitas experiências, passei a me sentir cidadã. Aprendi a conhecer melhor as pessoas, como elas falam uma coisa e fazem outras, a inveja, a ignorância, a mentira, a falsidade, a maldade. Tem aquelas que sonham em ser musas pois não passam de uma bunda, outros gostam de desfazer de quem tenta melhorar não conseguindo esconder seu despeito, políticos falam o que você quer ouvir e depois não fazem nada. Aprendi também que não importa ser competente e esforçado, pois o que importa é ser protegido do chefe, como o caso da Diretora da escola que nunca fez uma APP, privando a escola de verbas a mais 
de 2 anos e continua na direção, como se tudo tivesse certo. Como querer que a escola melhore se não tem pessoas capacitadas para administrar? Bancar incompetência com dinheiro público é fácil, queria ver uma situação dessas em escola particular. Falam em mudanças, renovação, tudo que precisa para se eleger e na hora de fazer as mudanças, nada muda. Quem cobra resultados? Quem cobra competência? Quem cobra compromisso? Quem cobra transparência? Estamos no ponto que quem cobra é ameaçado, é apedrejado, é isolado, é o errado, tem que fazer que não viu, que não sabe, não comentar para não se incomodar. O exemplo que vem da minha escola é que a incompetência e má gestão são normais, temos que nos acostumar e não adianta reclamar. Assim se percebe por que o povo se acomoda e aceita tudo que os governantes fazem sem reclamar. Somos treinados desde cedo a perceber que nada muda, que o Brasil é assim mesmo. Eu me nego ser assim. Acredito em mudanças, acredito em pessoas que querem mudar, acredito no Brasil! Vou publicar aqui novamente alguns recursos que as escolas públicas têm direito. Por isso peço a todos que fiscalizem a escola de seus filhos, cobrem, participem, não deixe que prejudiquem os direitos de seus filhos, não facilite.

Diário de Classe, 7-6-2013

Evidentemente, a postagem encarta várias representações em seu discurso. Embora entendamos serem questões relevantes para discussão, centramos nosso foco na compreensão da aluna a respeito de uma escola ideal. A postagem nos remete à interpretação de que a cultura brasileira é de um povo passivo que não cobra qualidade na educação. Ela sugere que esta cultura de passividade está arraigada no povo brasileiro, a ponto daquele que 
realiza cobranças "ser ameaçado, apedrejado, isolado, ser o errado, ter que fazer que não viu, que não sabe, não comentar para não se incomodar".

Ao fazer essa declaração, a aluna traz à tona o fato de esperar que a sociedade, neste caso a comunidade escolar, seja participativa, ao modo como ela está sendo, ainda que ocorram problemas semelhantes aos que ela esteja enfrentando.

Como em qualquer arena social, a palavra é disputada pelos indivíduos para assumir um poder. Aquele que a domina, ou pelo menos pensa que o faz, desempenha um papel de liderança. Por força disso, no excerto, vemos a aluna, desta pesquisa, lutando para ocupar um espaço que ela deseja - o direito de poder criticar o dizer do outro. Assim, em várias passagens da análise, a postagem da discente se revelou contraditória. Anteriormente, houve indícios de que ela preferia uma escola em que o aluno ouvisse o professor e, nesta postagem, conclama ao fato de que os sujeitos escolares sejam participativos.

Parecem-nos distantes essas duas visões, pois, de certa forma, ela não aceita ser uma pessoa que concorda com os fatos recorrentes, conforme demonstra em seu dizer: "Somos treinados desde cedo a perceber que nada muda, que o Brasil é assim mesmo. Eu me nego ser assim". Esse pensamento induz acreditarmos que a escola ideal é aquela em que os sujeitos sabem de seus direitos, conhecedores de quais recursos podem beneficiar as estruturas escolares, de acordo com suas representações sociais de melhoria já discutidas.

Esta contradição aparente, no dizer da aluna, pode entrar em consonância com o que Fairclough (2001), baseado em Foucault (1970/2012;1998), argumenta no sentido 
de que o poder não se apresenta inteiramente em um único lugar ou nas mãos de apenas um sujeito. Dito de outra forma, o poder parece não estar centralizado somente na escola - instituição considerada detentora do poder/saber por longos tempos (SIBILIA, 2012) -, tampouco somente nos alunos. A tendência da contemporaneidade é que os sujeitos vivenciem práticas de poder com seus diferentes mecanismos, de tal sorte que se tenham hierarquias ora mais verticais, ora mais horizontais.

\section{Considerações finais}

Ao longo deste texto, buscamos analisar o discurso de uma aluna responsável pela organização da comunidade "Diário de Classe", do Facebook. As escolhas lexicais apresentadas na materialidade linguística evidenciaram como a adolescente caracterizava a "realidade escolar" em seus textos. Percebemos que o discurso da aluna está sedimentado na concepção de uma escola disciplinadora, percepção forjada ao longo de nossa história de escolaridade. Assim, como vimos, as opções de palavras ou frases não nascem de um acaso, antes estão diretamente relacionadas com processos sociais e culturais mais amplos. (FAIRCLOUGH, 2001)

Esses processos decorrem de nossa interação com o outro, que tece os fios delicados das redes sociais que nos alimentam e constituem nossas práticas discursivas, que, em muitos casos, não são conscientes. Isso não quer dizer que somos mero fruto do meio ambiente, como acreditavam alguns romancistas naturalistas, mas nossa capacidade de pensar e agir é constituída socialmente. 


\section{•Referências}

ALVES, E.C.A. 2014. Fanfiction e aprendizagem da escrita na internet. Cuiabá, MT. Dissertação de Mestrado. UFMT, $100 \mathrm{p}$.

DIJK, T. A. V. Discurso e poder. DIJK, T. A. V. \& HOFFNAGEL, K. F. (orgs.) São Paulo: Editora Contexto, 2008.

FAIRCLOUGH, N. Discurso e mudança social. Trad: Izabel Magalhães, Brasília: Ed.UNB, 2001.

KING, N. \& HORROCKS, C. Interviews in qualitative research. Londres: Sage, 2010.

FOUCAULT, M. A ordem do discurso: aula inaugural no Collège de France, pronunciada em 2 de dezembro de 1970. 22. ed. São Paulo: Edições Loyola, 2012.

M. Microfísica do poder. Trad. Roberto Machado. Rio de Janeiro: Graal, 1998.

SIBILIA, P. Redes ou paredes: a escola em tempos de dispersão. Trad. Vera Ribeiro. Rio de Janeiro: Contraponto, 2012.

ZUBLER, E.P. 2014. Nas águas da tecnologia digital: os dizeres de um grupo de professores. Dissertação de Mestrado. UFMT, $140 \mathrm{p}$.

XAVIER, P.A.M. 2014. A ostra se abriu: percepções de alunos surdos sobre seu processo de aprendizagem de língua inglesa em um curso a distância. Dissertação de Mestrado. UFMT, $100 \mathrm{p}$. 


\title{
O CINEMA COMO ARTEFATO SEMIÓTICO MEDIADOR DA COMPREENSÃO E POTENCIALIZAÇÃO DOS PROCESSOS DE ENSINO-APRENDIZAGEM
}

\author{
Fábio Marques de Souza ${ }^{1}$
}

1 Docente permanente e Coordenador Adjunto do PPGFP/UEPB (Mestrado Profissional em Formação de Professores). Atualmente, está credenciado, como professor colaborador no POSLE/UFCG (Mestrado Acadêmico em Linguagem e Ensino) e no PPGEduC/ UFPE (Mestrado Acadêmico em Educação Contemporânea). Professor efetivo do Departamento de Letras e Artes da UEPB/ Campus I. Editor da coleção Ensino \& Aprendizagem, da EdUEPB. Cursou estágio de pós-doutorado no Programa de Pós-graduação em Educação Contemporânea (PPGEduC/UFPE), com pesquisa acerca da mediação, com o apoio das Tecnologias Digitais da Informação e Comunicação. Mestre e Doutor em Educação, tendo como foco de investigação o ensino-aprendizagem de Língua Estrangeira/Adicional e a formação de professores de línguas, obtidos, respectivamente, pela UNESP/Marília (2009) e pela Faculdade de Educação da USP (2014). Licenciado em Letras (UNESP/Assis - 2006) e em Pedagogia (UNINOVE - 2014). Líder dos grupos de pesquisa TECLIN, Tecnologias, Culturas e Linguagens e Formação de Professores de Línguas Estrangeiras/Adicionais da UEPB e membro do grupo de pesquisa Estudos Bakhtinianos (UNESP/CNPq). Tem experiência na educação básica e no ensino superior (no âmbito público e privado) e na autoria de materiais didáticos de Português, Inglês e Espanhol como línguas adicionais. email - fabiohispanista@gmail.com 


\section{Introdução}

As reflexões apresentadas neste artigo são mediadas pelo cinema, considerado - conforme a perspectiva sociocultural - como artefato cultural, ferramenta de mediação simbólica potencializadora do desenvolvimento humano. Ao adotarmos termos como artefato e ferramenta, não pretendemos reduzir a arte a um mero caráter utilitário. Pelo contrário, segundo a perspectiva sociocultural que comungamos, estes termos ganham uma dimensão ampla já que a relação homem-mundo é uma relação mediada por artefatos e ferramentas físicas, sociais e simbólicas, como explicaremos a seguir.

Neste sentido, para Vigotski, a relação do homem com o mundo não é uma relação direta, mas, fundamentalmente, mediada por sistemas simbólicos. Complementando, Vieira Abrahão (2012) nos apresenta a mediação como um conceito central da teoria sociocultural, "sendo o processo por meio do qual os seres humanos se utilizam de artefatos culturalmente construídos, de conceitos e de atividades para regular o mundo material ou seu próprio mundo e suas atividades sociais e mentais reciprocamente" (p. 5).

Dessa forma, a mediação pode se dar por instrumentos ou signos:

O signo age como um instrumento da atividade psicológica de maneira análoga ao papel de um instrumento no trabalho. Os instrumentos, porém, são elementos externos ao indivíduo, voltados para fora dele; sua função é provocar mudanças nos objetos, controlar processos da natureza. Os 
signos, por sua vez, também chamados por Vygotsky de 'instrumentos psicológicos' são orientados para o próprio sujeito, para dentro do indivíduo; dirigem-se ao controle de ações psicológicas, seja do próprio indivíduo, seja de outras pessoas. São ferramentas que auxiliam nos processos psicológicos e não nas ações concretas, como os instrumentos (OLIVEIRA, 1993, p. 30).

Em consonância com esta reflexão, Johnson (2009) acrescenta que as ferramentas das quais lançamos mão para a mediação da nossa relação com o mundo podem ser físicas, sociais ou simbólicas. Diante do exposto, neste capítulo, partindo do pressuposto de que nossas reflexões acerca das crenças que permeiam a aquisição da língua espanhola e o tratamento da variação linguística por professores brasileiros deste idioma em formação inicial serão mediadas pelo cinema, apresentaremos o potencial da sétima arte em levar à tela de projeção a vida em seus múltiplos aspectos, enfatizando o potencial representacional das inquietações e desejos mais íntimos da alma humana.

Teceremos considerações a respeito das várias vias de estudo com vistas à compreensão do cinema, com foco na indústria, nas artes, nas invenções, no entretenimento e ressaltamos seu potencial para propiciar a compreensão da cultura escolar, bem como sua capacidade de potencializar o processo de ensino-aprendizagem.

Neste texto empregamos o termo cinema em sentido amplo, como imagem em movimento, independente do 
suporte, exceto quando fizermos referência explícita nesse sentido.

A primeira sessão. 28 de dezembro de 1895. No salão indiano do Grand Café, bulevar dos Cupuchinhos, em Paris, os trinta e três convidados dos irmãos Lumière vão assistir a um extraordinário espetáculo. Sobre uma pequena tela, uma fotografia recém-projetada de repente ganha vida. Carros, cavalos, pedestres começam a andar. Toda a vida de uma rua aparece. 'Diante desse espetáculo, ficamos boquiabertos', declarará o célebre prestigiador Georges Méliès. A invenção em breve vai atrair multidões e dar volta ao mundo (MARCHAND, 1995, p.6).

É consenso entre os estudiosos que a definição inicial para o cinema foi uma técnica de registro do movimento. Entretanto, ao longo da história, com acréscimos de elementos estéticos, sons, mudança de planos, angulações, enquadramentos, movimentos de câmera, iluminações e tecnologia, passou a ser reconhecido como "a sétima arte" e se apresenta como uma das mais ricas e completas manifestações artísticas que o ser humano já teve a capacidade de desenvolver; isto porque o fazer cinematográfico engloba todos os demais processos de criação artística já vividos (música, dança, pintura, escultura, teatro e literatura). 
Além de representar a vida, a arte cinematográfica dá forma às inquietações e desejos mais íntimos da alma humana. O filme reúne extraordinário número de informações nas diferentes áreas da experiência. As discussões sobre o cinema - ao longo do tempo - têm se encaminhando por diversos focos: o da indústria, das artes, das invenções, do entretenimento.

Silva (2006), ao tecer reflexões acerca do cinema e os vínculos sociais, utiliza a cena do filme Ônibus $174 \mathrm{em}$ que aparece o ônibus com o sequestrador, de arma na mão, com um apanhado de corpos confinados pelo terror num veículo estático, como uma metáfora da vida contemporânea. Para ela, apesar da "violência do filme, um ônibus parado e um entorno de imagens em movimento são metáforas da vida urbana, território atual do sedentarismo de seres que eram, na sua sociabilidade inicial, nômades (p.227)".

De acordo com a autora, o cinema realiza, para o homem sedentário, a viagem que o espírito anseia, sem que haja a necessidade de deslocamento de lugar. Apesar de o movimento relacionar-se ao prazer, no cinema há a dualidade entre esse e a angústia devido ao fato de ser o movimento nada mais do que um contínuo de imagens luminosas em fotogramas sucessivos que são ampliados de forma simbólica pela montagem. É ele o responsável por transformar as lacunas entre os fotogramas, intermediando a ligação com o sentido do movimento. "A imagem-movimento do cinema é, assim, um 'entre', um ponto médio entre duas imagens, como pretende Deleuze, uma ausência-presença que simboliza a perfeição, o conflito prazer angústia produzida pelo cinema" (p. 228). 
O cinema, além de mascarar a saciedade de carência de movimento deste homem que um dia foi nômade, cumpre a função da fabulação necessária ao espírito, conforme nos apresenta Cândido (1995). A partir das afirmações deste autor, podemos apreciar a arte como uma necessidade básica, já que se trata da manifestação universal de todos os homens em todos os tempos:

Não há povo e não há homem que possa viver sem ela, isto é, sem a possibilidade de entrar em contato com alguma espécie de fabulação. Assim como todos sonham todas as noites, ninguém é capaz de passar as vinte e quatro horas do dia sem alguns momentos de entrega ao universo fabulado. $\mathrm{O}$ sonho assegura durante o sono a presença indispensável deste universo, independente da nossa vontade. E durante a vigília a criação ficcional (...) está presente em cada um de nós, analfabeto ou erudito, como anedota, causo, história em quadrinho, noticiário policial, canção popular, moda de viola, samba carnavalesco. Ela se manifesta desde o devaneio amoroso ou econômico no ônibus até a atenção fixada na novela de televisão ou na leitura de um romance (p. 242).

Ao argumentar sobre o direito à literatura, que - neste contexto - expandimos às artes, grupo no qual o cinema se encaixa, sabemos que as manifestações artísticas 
correspondem "a uma necessidade universal que deve ser satisfeita sob pena de mutilar a personalidade, porque pelo fato de dar forma aos sentimentos e à visão do mundo ela nos organiza, nos liberta do caos e, portanto, nos humaniza" (CÂNDIDO, 1995, p. 256).

Humanização aqui é entendida como um processo que caracteriza o homem com traços ditos essenciais: capacidade de refletir, de adquirir conhecimento e sabedoria, boa disposição ao relacionar-se com o outro, afinamento das emoções e capacidade de percepção do que é belo e complexo.

\section{O cinema nos permite outras maneiras de olhar para 0 mundo e, assim, compreender a nós mesmos}

Adentramos a sala de projeção e somos envolvidos num emaranhado de imagens e sons que atinge nossa alma, expondo nossas paixões, frustrações, desejos, inquietações. Uma breve análise pela trajetória do cinema nos revelará que, desde a década de 1960, a sétima arte vem passando por uma mudança de abordagem e tem se transformado em um dos mais fortes canais de comunicação e significação sociocultural. Neste sentido, Turner (1997), ao nos apresentar o cinema como prática social, nos alerta para o fato de que compreender um filme não é essencialmente uma prática estética; é uma prática social que mobiliza toda uma gama de sistemas no âmbito da cultura.

Ao pensarmos no cinema a partir do tema arte e entretenimento na contemporaneidade, devemos levar em consideração que ele vai além da projeção do filme e constitui um complexo sistema constituído por elementos como a 
indústria, o mercado de filmes, o roteiro, o argumento, as locações, os atores, a produção, as interpretações, as conversas depois do filme, dentre tantas outras coisas.

Almeida (1994) cita a sala de projeção como o local de encontro entre os que produzem e os que o consomem o cinema. Para ele, trata-se do momento estético em que um objeto artística e tecnicamente produzido vai ao encontro do imaginário do espectador, relaciona-se intimamente com seus desejos, ressentimentos, vontades, ilusões, raivas, prazeres, traumas, vivências, e sobre o qual só teremos nossa objetividade restituída após o término da projeção.

Com o seu aparato tecnológico apropriado para documentar, registrar de forma estética e narrar histórias, o cinema nos permite uma nova maneira de olhar para o mundo e, com isso, estabelece uma forma peculiar de inteligibilidade e conhecimento. Esta arte pode ser utilizada, desde a educação infantil ao ensino superior, como um dispositivo didático lúdico e atrativo, valioso na formação de novas gerações, possibilitando o encontro simultâneo com a cultura cotidiana e erudita, pois é o campo no qual a estética, o entretenimento, a ideologia e os valores sociais mais amplos são sintetizados numa mesma obra.

Quanto mais o espectador de cinema se empenhar em compreender/analisar os filmes aos quais assiste, maiores serão as chances de se aproximar da intencionalidade e seleção de sentidos pretendidas pelos idealizadores, das características culturais e das ideologias de suas escolhas, permitindo compará-las a sua própria cultura e valores. Neste sentido, do relacionamento espectador-filme pode surgir uma consciência humano-social com capacidade de resignificar o audiovisual e ir além dele, num processo 
quase subliminar, propício à formação de novas percepções e entendimento da vida em sociedade.

Neste sentido, Trevizan (1998) aponta que o potencial artístico de um bom filme não se sustenta somente no reconhecimento da credibilidade da história contada, mas reside, sobretudo, na possibilidade de a linguagem criada estabelecer com o espectador um nível profundo de comunicação intelectual, filosófica, psicológica, emocional, fazendo com que ele reflita sobre si mesmo e sobre o outro.

Diante do exposto, nosso objetivo neste artigo é, a partir da pesquisa bibliográfica, apresentar as contribuições do cinema para a compreensão e potencialização do processo de ensino-aprendizagem. Neste intuito, iniciamos nosso trajeto refletindo acerca da sociedade contemporânea, submersa em imagens, sons e movimentos. Na sequência, apresentamos a capacidade do cinema em nos permitir outras maneiras de olhar para o mundo e, assim, compreender a nós mesmos. No próximo item, nos dedicaremos aos vários usos do cinema e vídeo na escola, a possibilidade da pesquisa em educação com base nas artes, algumas contribuições da prática cineclubista e as contribuições do cinema no aprimoramento da competência intertextual.

\section{A sociedade submersa em imagens, sons e movimentos}

É inegável a presença das imagens, sons e movimentos em nosso cotidiano. Já é consenso entre vários estudiosos que o cinema não nasceu mudo, mas em meio a narradores, explicadores, conferencistas, conversas, cantorias, 
enfim, em uma grande intersemiose. Neste ponto, damos destaque à compreensão da importância do montador na construção dos sentidos em meio ao emaranhado de signos que compõem uma cena. O próprio cinema nos tornou mais conscientes disto, por exemplo, quando nos apresentou Elizaveta Svilova restaurando o tempo em O homem com a Câmera (VERTOV, 1929). Atualmente, a produção e a circulação de imagens se dão de forma interativa e dinâmica, como aponta Di Camargo (2009):

Desde as tradicionais artes plásticas, passando pela fotografia, pelo cinema, pela TV e chegando à Internet, o homem tem utilizado diversos recursos para se comunicar através da imagem. E, analisando os contextos da produção imagética, percebe-se que as imagens estão ligadas à arte, ao jornalismo, à publicidade, enfim, aos vários campos de produção de sentido, como um elemento imprescindível para o processo de comunicação (p. 27-28).

As linguagens audiovisuais têm presença marcante na produção cultural contemporânea, o que pode ser observado desde a propaganda até a sofisticada produção cinematográfica contemporânea. São vários os gêneros que utilizam a linguagem audiovisual como ferramenta essencial: filmes, telenovelas, vídeos, minisséries e videoclipes, os quais estão cada vez mais presentes em nossa cultura e tecnologicamente mais sofisticados. 
É inegável a revolução causada pela Internet na produção e circulação da linguagem audiovisual. A teia de alcance mundial mudou nossa forma de acesso à informação; a maneira de concebê-la (de forma hipertextual e multimodal); nossa forma de entretenimento e o panorama educacional. Cabe destacar também que a internet possibilita ao usuário a possibilidade de desempenhar um papel ativo, de emissor criador de conteúdo audiovisual e não somente o tradicional consumidor de conteúdo. Diante da gama de possibilidades para criação e consumo de produtos audiovisuais, faz-se necessário sensibilizar o espectador para compreender os vários discursos presentes nos produtos culturais transmitidos pela mídia:

Principalmente [pela] televisão, objeto popular de consumo, canal ideal para a propagação da cultura de massa. E também o cinema, uma forma complexa de fazer arte que difere das tradicionais em diversos aspectos. Sem a intenção de fazer um julgamento preconceituoso, faz-se necessário realizar uma leitura mais crítica dessa linguagem cada vez mais sofisticada. E conveniente rever o modo como enxergamos a comunicação de massa, a fim de que possamos participar, de forma politizada, desse processo de produção e consumo (DI CAMARGO, 2009, p. 28). 
O audiovisual é a linguagem do principal meio2 de comunicação social e tem presença marcante na produção cultural contemporânea, o que pode ser observado desde a propaganda até a sofisticada produção cinematográfica contemporânea. São vários os gêneros que utilizam a linguagem audiovisual como ferramenta essencial: filmes, telenovelas, vídeos, minisséries e videoclipes, os quais estão cada vez mais presentes em nossa cultura e tecnologicamente mais sofisticados (DI CAMARGO, 2009).

Vários estudiosos destacam as potencialidades da sétima arte no processo educativo. Napolitano (2003, p. 11-12), por exemplo, comenta que o trabalho com o cinema pode auxiliar a escola a reencontrar a cultura ao mesmo tempo cotidiana e elevada, pois o cinema é o campo no qual a estética, o lazer, a ideologia e os valores sociais mais amplos são sintetizados numa mesma obra de arte.

Neste sentido, Trevizan (1998, p. 85) cita que o filme congrega informações nas diferentes áreas da experiência humana e por isso deve ser utilizado, nas escolas, com o um instrumento didático. A autora destaca ainda o papel valioso desta mídia na formação de novas gerações.

\section{Os vários usos do cinema e vídeo na escola}

Em artigo acerca do vídeo na sala de aula, Moran (1995, p. 27) destaca que este dispositivo auxilia o bom professor, atrai os alunos, mas não modifica substancialmente a relação pedagógica. $\mathrm{O}$ pesquisador argumenta que as mídias aproximam a sala de aula do cotidiano, das

2 Do latim medius, com plural em media, que nos remete à mídia. 
linguagens de aprendizagem e comunicação da sociedade urbana, mas também introduz novas questões no processo educacional.

$\mathrm{O}$ autor nos apresenta vários usos do vídeo em sala de aula. Como usos inadequados, temos o vídeo-tapa-buraco; vídeo-enrolação; vídeo-deslumbramento e o vídeo-perfeição. Como possibilidades desejáveis de utilização o pesquisador relaciona o vídeo como sensibilização, ilustração, simulação, conteúdo de ensino, produção, avaliação, espelho e interação/suporte de outras mídias. Comentaremos, a seguir, cada uma dessas categorias elencadas.

Para ele, o "vídeo-tapa-buraco" ocorre quando exibimos um vídeo para sanar um problema inesperado, como, por exemplo, a falta do professor. O autor argumenta que "usar este expediente eventualmente pode ser útil, mas se for feito com frequência desvaloriza o uso do vídeo e o associa - na cabeça do aluno - a não ter aula" (MORAN, 2003, p. 34).

O "vídeo-enrolação" aconteceria com a exibição de um vídeo sem muita relação com o conteúdo que está sendo estudado. Nesta situação, o alunado até pode não reclamar na hora e ser coautor do mau uso, mas sabe que o vídeo é usado como forma de camuflar a aula.

Outra situação seria o "vídeo-deslumbramento", que ocorre quando o professor que acaba de descobrir o uso do vídeo se empolga e passa vídeo em todas as aulas, esquecendo outras dinâmicas mais pertinentes, neste caso, "o uso exagerado do vídeo diminui a sua eficácia e empobrece as aulas" (MORAN, 2003, p. 34).

Situações negativas causadas pelo professor que sempre questiona todos os vídeos possíveis, apresentado 
defeitos de informação ou estéticos, são consideradas pelo autor de "vídeo perfeição". Segundo ele, as obras sempre serão representações e, no caso dos "vídeos que apresentam conceitos problemáticos podem ser usados para descobri-los, junto com os alunos, e questioná-los" (MORAN, 2003, p. 34).

Outra forma indesejada de utilização consiste no "só vídeo", quando o professor não explora o material, ficando na mera exibição, sem discussão e nem integração com outros assuntos da aula.

Dentre as propostas desejáveis de utilização, o autor apresenta o "vídeo como sensibilização", como um dos mais importantes na escola: "um bom vídeo é interessantíssimo para introduzir um novo assunto, para despertar a curiosidade, a motivação para novos temas. Isso facilitará o desejo de pesquisa nos alunos para aprofundar o assunto do vídeo e da matéria" (MORAN, 2003, p. 34).

O "vídeo como ilustração" tem o potencial de reunir muitos contextos, na maioria das vezes distantes da realidade do aluno, em uma só mídia e permite exemplificar e/ou complementar o que é visto em sala de aula, auxiliando os alunos na compreensão de cenários desconhecidos, de outros tempos históricos. Neste sentido, "a vida se aproxima da escola através do vídeo" (MORAN, 2003, p. 35). O pesquisador argumenta que um vídeo pode trazer para a sala de aula realidades distantes dos alunos, como, por exemplo, a Amazônia ou a África.

O cinema pode ser utilizado em atividades que visem desmistificar conceitos cristalizados acerca da língua e cultura estrangeira que está sendo estudada, como no caso do espanhol, pois permite apresentar diversas realidades e variedades linguísticas e culturais num mesmo 
contexto, isto é, na sala de aula, de maneira a permitir o trabalho com as crenças e a desconstrução de estereótipos negativos.

Neste sentido, o cinema pode ser um material didático, definido pelas Orientações Curriculares para o Ensino Médio - Espanhol, como o conjunto de recursos dos quais os professores se valem em suas práticas pedagógicas, "entre os quais se destacam, grosso modo, os livros didáticos, os textos, os vídeos, as gravações sonoras (de textos, canções), os materiais auxiliares ou de apoio, como gramáticas, dicionários, entre outros" (OCEM, 2008, p. 154) que exercem um papel importante na sala de aula.

A utilização do cinema como recurso didático pode propiciar momentos de encontro com o Outro, sua língua e sua cultura, e mostrar aos alunos realidades muitas vezes desconhecidas e distantes, tornando o aprendizado mais significativo e prazeroso.

Neste sentido, já é sabido que para que o ensino de uma língua seja mais eficaz é necessário não só aprender gramática, mas ir além da simples sensibilização do aluno quanto a questões socioculturais, como afirma Goettenauer (2005):

A questão não é apenas sensibilizar o aluno e buscar formas para ensejar atitudes imparciais diante de outros valores, outras tradições, outros modos de ver, viver, e nomear a realidade. Trata-se de algo bem mais complexo: acolher o outro e compartilhar com ele hábitos, costumes, ideias (...). Apropriar-se de uma 
língua distinta da materna é apropriar-se de novas lentes para mirar o mundo (p. 64).

Outra rica possibilidade é o "vídeo como simulação" já que nos permite ilustrar a aula de forma mais sofisticada, por exemplo, "o vídeo pode simular experiências de química que seriam perigosas em laboratório ou que exigiriam muito tempo e muitos recursos. Um vídeo pode mostrar o crescimento acelerado de uma planta, de uma árvore - da semente até a maturidade - em poucos segundos" (MORAN, 2003, p. 35).

$\mathrm{O}$ "vídeo como conteúdo de ensino", parte do pressuposto de que a mídia pode abordar temas direta ou indiretamente. Ao apresentar o "vídeo como produção", o autor subdivide esta categoria em três itens: a) como documentação, registro de eventos, aulas, estudos do meio, experiências, entrevistas, depoimentos; b) Como intervenção: interferir, modificar um determinado programa, um material audiovisual, acrescentando uma trilha sonora ou editando o material de forma compacta ou introduzindo novas cenas com novos significados, "assim como ele interfere num texto escrito, modificando-o, acrescentando novos dados, novas interpretações, contextos mais próximos do aluno" (MORAN, 2003, p. 35); c) como expressão, como nova forma de comunicação, adaptada à sensibilidade principalmente das crianças e dos jovens:

As crianças adoram fazer vídeo e a escola precisa incentivar ao máximo a produção de pesquisas em vídeo pelos alunos. A produção em vídeo 
tem uma dimensão moderna, lúdica. Moderna como um meio contemporâneo, nova e que integra linguagens. Lúdica, pela miniaturização da câmera, que permite brincar com a realidade, levá-la junto para qualquer lugar. Filmar é uma das experiências mais envolventes tanto para as crianças como para os adultos. Os alunos podem ser incentivados a produzir dentro de uma determinada matéria, ou dentro de um trabalho interdisciplinar. E também produzir programas informativos, feitos por eles mesmos e colocá-los em lugares visíveis dentro da escola e em horários em que muitas crianças possam assistir a eles (MORAN, 2003, p. 36).

Outra proposta seria a do "vídeo como avaliação", o que inclui os alunos, o professor, e o processo de ensino-aprendizagem. $\mathrm{O}$ autor destaca também o "vídeo-espelho"; nele, "vejo-me na tela para poder compreender-me, para descobrir meu corpo, meus gestos, meus cacoetes" (MORAN, 2003, p. 36). Esta categoria permite a análise do grupo e dos papéis de cada um, para acompanhar o comportamento individual, do ponto de vista participativo, para incentivar os mais retraídos e pedir aos que falam muito para darem mais espaço aos colegas. $\mathrm{O}$ autor argumenta também que o vídeo-espelho é de grande utilidade para o professor se ver, examinar sua comunicação com os alunos, suas qualidades e defeitos.

A última possibilidade apresentada seria a do "vídeo como interação/suporte de outras mídias"; nela o autor 
destaca o vídeo como suporte da televisão e do cinema e a interação do vídeo com outras mídias, como o computador, celular, videogames, internet.

\section{Pesquisa em educação com base nas artes}

Neste momento, compartilharemos das ideias de Moraes (2004, p. 53), para quem os filmes, além de um recurso para a prática educacional - na medida em que os utilizamos em sala de aula -, podem ser objetos de pesquisa - nos quais buscamos entender as várias lentes que se cruzam na representação da cultura escolar.

Dessa forma, é possível ir além da exploração da sétima arte como recurso para a prática educacional, partindo para o texto fílmico como objeto de pesquisa para a compreensão das funções, objetivos, práticas e agentes escolares veiculados por esta mídia.

Levando-se em consideração que a linguagem cinematográfica estabelece com o espectador uma comunicação intelectual, filosófica, psicológica e emocional, fazendo com que ele reflita sobre si mesmo e sobre o outro, é possível analisar os diversos recursos da linguagem cinematográfica utilizados pelos cineastas e como essas opções estéticas influenciam na construção do olhar do espectador sobre a realidade escolar, bem como a escola é representada pela sétima arte. Isto é, como as produções cinematográficas colaboram na construção de referência do imaginário a respeito do ambiente escolar. 
Propostas neste sentido se inserem no campo da Pesquisa Educacional com base nas Artes ${ }^{3}$, via pesquisa qualitativa de cunho interpretativista que, concebendo o cinema como prática social e a partir da teoria da representação cultural, pretende compreender as vozes engendradas pela linguagem cinematográfica para compor as narrativas fílmicas nas quais é retratada a cultura escolar.

Embora o trabalho dos artistas seja sempre considerado da perspectiva ampla da criatividade, vários artistas contemporâneos se empenham na realização de formas altamente sistemáticas e profundas de pesquisa... Ao prepararem um espetáculo teatral, por exemplo, diretores, dramaturgos e atores frequentemente realizam uma ampla investigação da linguagem e dos costumes daquele período ou mesmo a história das produções daquele determinado trabalho (...). Compositores e artistas performáticos pesquisam, coletam histórias orais e se empenham em estudos etnográficos sem dar nomes ao que fazem (SABATINI, 1993 apud TELLES, 2004).

Telles (2006) relata que um dos pioneiros a citar o potencial das artes para buscar instrumentos e formas alternativas de representação das pesquisas em educação

3 Arts-Based Educational Research (EISNER, 1991, 1997; DIAMOND \& MULLEN, 1999; TELLES, 2004 e 2005), Arts-informed Research ou Arts-Based Approaches to Qualitative Inquiry (GRAY, 2003). 
foi Eisner (1991). Para esse educador, as artes têm uma longa tradição em descrever, interpretar e avaliar o mundo e dar forma à experiência.

Exemplos de experiências vicárias são encontrados nas artes. Por meio da forma artística de pesquisa conhecida como narrativas de histórias educacionais, o leitor pode experienciar, de forma vicária, um mundo virtual crível da escola ou sala de aula, habitado por pessoas que são as personagens virtuais da história. Este tipo de experiência estética pode ser suficientemente significativa a ponto de causar um questionamento das premissas fundamentais dos valores, assim como das bases ideológicas sobre as quais as decisões relativas à educação são tomadas. (DENZIN, 1992, p. 15).

Nesta perspectiva do cinema como fonte de pesquisa para a compreensão das possíveis representações da cultura escolar, cabe citar Pinheiro (2010), Fabris (2005) e as pesquisas de Telles $(2004,2005)$.

A dissertação de mestrado de Pinheiro (2010) verifica as representações sociais relacionadas à escola a partir da comparação das imagens levadas à tela pela produção francesa Os incompreendidos (1959) e pelo filme chileno Machuca (2004).

Outro trabalho nesta linha com o qual tivemos contato é a tese de Fabris (2005). Nela, a autora toma o cinema como objeto de compreensão da cultura escolar e analisa 
como o cinema brasileiro representa a escola e o trabalho docente no contexto de dezessete filmes nacionais.

Telles (2004) utiliza o espetáculo teatral como dispositivo de reflexão e representação do desenvolvimento do professor e tece reflexões acerca da pesquisa educacional com base nas artes e na reflexão compartilhada, defendendo a necessidade de formas alternativas de representação da docência e do conhecimento dos professores.

\section{Contribuições da prática cineclubista para a formação humana}

Conforme cita Andrade (2010, p. 212), “o [sistema] cineclubista é aquele que se dedica a divulgar e discutir o cinema como obra de arte, como pensamento, como renovação do olhar, do pensar e do sentir. E não como consumo, pura e simplesmente". Macedo (2005, p. 29) apresenta-nos três características dos cineclubes: i) não ter fins lucrativos; ii) possuir uma estrutura democrática; iii) ter um compromisso cultural e ético.

Segundo o autor, os primeiros cineclubes apareceram como uma resposta quase que automática ao excesso de estandardização que o monopólio do cinema ia instaurando. Os coletivos se agruparam cheios de ilusões sobre a "sétima arte" e o papel do "belo". No entanto, mesmo assim, eles já surgiram como uma organização sem fins lucrativos - o que os diferenciava dos valores de mercado -, já nasceram baseados numa estrutura coletiva e democrática (em maior ou menor grau, mas sempre democrática) e se formaram com uma comprovada disposição de se contrapor ao poder monopolizado e alienador do cinema comercial, ressaltando as produções que não encontravam 
distribuição no mercado comercial ou que eram repelidas por motivos estéticos, políticos. Dessa forma, os cineclubes afloraram como uma maneira de organização coletiva.

Além de permitir ao homem sedentário, que incialmente era nômade, a viagem da alma sem que o corpo saia do lugar o cinema também teve, em seu início um caráter de nomadismo que ainda hoje permanece em algumas regiões do Brasil. Neste sentido, podemos destacar que as primeiras sessões de cinema realizadas no Brasil cumpriam essa função de movimentação simbólica, além de terem um caráter itinerante pela própria limitação técnica.

Atualmente, ocorre no Brasil um grande número de sessões semelhantes a essas primeiras por seu caráter nômade, itinerante, e arcaicamente comunitário. Elas reúnem espectadores em centros comunitários, quadras de esporte, ruas de bairros periféricos, hospitais, presídios, praças interioranas. A falta de salas específicas e adequadas para a exibição cinematográfica colabora em muito para que essa situação se dê. Segundo a Pesquisa de Informações Básicas Municipais do IBGE - Instituto Brasileiro de Geografia e Estatística, 92 por cento das cidades brasileiras não possuíam salas de cinema até 1999 (SILVA, 2006, p. 228).

A pesquisadora relata que as sessões comunitárias existentes até hoje não se dão unicamente pela falta de salas de projeção, mas pela necessidade de socialização 
do ser humano, já que "ver produtos da indústria cultural numa tela de cinema é participar afetivamente de um movimento lúdico que remete constantemente ao outro e, reflexivamente, a si mesmo (SILVA, 2006, p.229)".

A familiaridade e a vinculação institucional com o local de projeção conferem ao espaço da sessão comunitária uma significação diferente daquela atribuída à sala de cinema comercial. A movimentação das pessoas se dá de maneira mais fluida, aparentemente mais descontraída e festiva. O conhecimento dos espectadores entre si e com os organizadores do evento também modifica a qualidade da interação. Os indivíduos são reconhecidos como tal e isso diminui a formalidade dos procedimentos de aproximação, facilitando o encontro. Outros comportamentos típicos do anonimato (pôr os pês sobre o espaldar da cadeira da frente ou jogar lixo no chão) são inibidos. Ainda que seja assim, qualquer tipo de filme ou de sessão de cinema alimenta produções simbólicas e relações sociais que se estabelecem em torno do filme. Quando essas relações envolvem vínculos comunitários mais caracterizados, a mobilização do público é muito intensa, excede o evento (SILVA, 2006, p.229). 
Alves (2010) apresenta-nos a formação humana como um problema crucial do nosso tempo histórico; para ele "uma democracia sem democratização radical é o anseio oculto do capitalismo histórico" (p. 13). Neste sentido, o autor apresenta como característica a constituição do capitalismo manipulatório, "que se tornou hoje um sistema mundial organizado pela oligarquia industrial-financeira, que controla os aparatos de 'formação de opinião pública', sob o controle do capital concentrado dos grandes grupos da indústria cultural" (p. 13).

Diante da formação humana como um problema crucial do nosso tempo histórico, acreditamos que a prática cineclubista, principalmente em ambientes educacionais, pode colaborar para a promoção de uma formação integral e plena, já que, infelizmente, $90 \%$ das cidades brasileiras não têm sala de cinema, torna-se fundamental promover novas formas de acesso e difusão cultural:

No Brasil, para ficarmos exclusivamente no campo do audiovisual, apenas cerca de $10 \%$ dos municípios tem salas de cinema, e é esse também o percentual de brasileiros que vê algum filme no cinema pelo menos uma vez por ano. Se todos têm televisores, o acesso a programações diferenciadas (TV por assinatura), é da mesma magnitude que o cinema. $\mathrm{O}$ acesso regular à internet tem crescido muito, mas ainda é privilégio de uma minoria. A quase totalidade das comunidades brasileiras não tem museus, teatros, bibliotecas, etc. No 
resto da América Latina, África e grande parte da Ásia - onde se concentram $80 \%$ da população mundialos indicadores são semelhantes, frequentemente piores (MACEDO, 2010, p. 33).

Dito de outra maneira, o autor destaca que mais de 90\% dos municípios brasileiros não têm cinema e o mesmo percentual de exclusão se aplica ao público, já que menos de $10 \%$ da população do Brasil vai ao cinema pelo menos uma vez por ano. Macedo (2005) argumenta que o cinema ao qual um décimo da população brasileira tem acesso é o cinema "produzido no famoso distrito da cidade de Los Angeles, Hollywood, onde se concentra a indústria que controla $85 \%$ dos mercados cinematográficos de todo o mundo" (p. 4):

Esse 'produto' ocupa, de forma predatória, todo o espaço cultural, procurando substituir o imaginário do nosso povo, sufocado qualquer outra expressão e matando toda diversidade. Pois dentre esses $10 \%$ da população que vão [sic] ao cinema, são cerca de $10 \%$ os que veem um filme brasileiro ou de outra nacionalidade, inclusive os filmes americanos não produzidos pelas grandes corporações hollywoodianas. Em outras palavras, só $1 \%$ dos brasileiros têm algum contato com filmes brasileiros e de todo o resto do mundo, somados (MACEDO, 2005, p.5). 
Ao argumentar acerca da potencialidade dos cineclubes em espaços escolares, Alves (2010, p. 13) ressalta que, na medida em que a prática cineclubista conseguir elaborar metodologias pedagógicas capazes de irem além da mera exibição do filme e, inclusive, de mera discussão entretida da narrativa fílmica, ela se coloca num campo precioso da subversão cultural contra a ordem "imbecilizante" do capital. Neste sentido, devemos ter como meta, ir além da tela no sentido de criar, por meio da prática cineclubista, espaços de produção de conhecimento crítico.

Vivemos, de fato, uma total massificação de valores [...]. É preciso mostrarmos a alma humana destituída de fórmulas convencionalizadas, de estereótipos. É necessário que o homem redescubra o seu próprio significado diante do mundo codificado que se lhe apresenta (TREVIZAN, 1998, p. 96).

Diante da importância de promover o trabalho com o cinema em contextos de formação, Souza (2014) compartilha da experiência de dois planos de trabalho que propõem a prática cineclubista em Monteiro- $\mathrm{PB}$, cidade do cariri ocidental paraibano que, assim como $90 \%$ das cidades brasileiras, não tem sala de cinema.

No Campus VI da Universidade Estadual da ParaíbaUEPB, o Núcleo de Espanhol desenvolve semanalmente o "Cinema dos outros", que visa a exibição e discussão de filmes do universo hispânico, com vistas à alteridade e à interculturalidade. O projeto "cinema como arte, 
entretenimento, ferramenta e prática social" que lideramos tem três focos de atuação: i) complementar e fortalecer a prática cineclubista: exibição, análise e discussão no campus; ii) constituir um grupo interdisciplinar de estudos e pesquisas sobre o cinema; iii) desenvolver oficinas para produção de material didático e formação de multiplicadores na aquisição do E-LE mediada pelo cinema.

Macedo (2005, p. 20) relata que $60 \%$ dos jovens entre 15 e 29 anos nunca foram ao cinema. No caso da pesquisa de Souza (2014), uma coleta de dados feita com os alunos do curso de Letras-Espanhol do Campus VI revelou que $59 \%$ deles nunca foram ao cinema. Um total de $42 \%$ dos participantes declarou que raramente assiste a filmes, em casa ou com amigos. Esses dados revelam que o público daquele contexto não tem o costume de consumir/apreciar o cinema.

\section{Algumas pesquisas que utilizam o cinema no ensino de línguas e na formação de professores}

No que concerne às pesquisas que utilizam o cinema como mediador no ensino de línguas, tivemos contato com as investigações de Garcia de Stefani (2010) e Gómez Alibés (2008). No campo da formação inicial e continuada de professores de línguas, conhecemos os trabalhos de Mayrink (2007), Souza (2014) e Garcia de Stefani (2014).

Garcia de Stefani (2010) desenvolveu uma pesquisa de mestrado na qual argumenta que embora o cinema possa configurar-se como um recurso didático eficiente para a implementação do ensino comunicativo de línguas, por seu caráter lúdico e por sua capacidade de promover maior envolvimento dos alunos na realização de atividades 
significativas, percebe-se que seu uso ainda é bastante limitado no âmbito de ensino de língua estrangeira.

A partir desta constatação, o objetivo da pesquisa qualitativa de base etnográfica desenvolvida pela pesquisadora foi investigar o uso do filme Diários de Motocicleta como conteúdo didático no contexto de ensino de espanhol como língua estrangeira, tomando por base os pressupostos teóricos da aprendizagem significativa. A pesquisadora argumenta que a análise dos dados revela que o filme representa uma maneira eficaz de apresentar o insumo linguístico contextualizado, de envolver os alunos em atividades de interação e negociação de sentidos, de estimular o pensamento crítico e o conhecimento de mundo, além de contribuir significativamente para o desenvolvimento da autonomia do aluno como aprendente de línguas.

Gómez Alibés (2008) propõe a substituição das tradicionais gravações de áudio dos livros didáticos por fragmentos de filmes como uma nova visão da apresentação de situações cotidianas na aula de E-LE.

O autor argumenta que há uma série de situações típicas pelas quais qualquer pessoa pode passar vivendo em um país estrangeiro que a maioria dos livros didáticos de E-LE, geralmente, apresentam em suporte de áudio, dentre elas: fazer pedidos em um restaurante, perguntar o caminho para um pedestre, registrar um boletim de ocorrência em uma delegacia, realizar operações bancárias, resolver problemas no aeroporto, se expressar em um consulta médica, alugar um imóvel, interagir em uma entrevista de emprego, fazer uma reserva em um hotel. 
O pesquisador conclui ser possível substituir esses arquivos de áudio tradicionais por trechos de filmes que apresentam usos diários e reais da linguagem de forma autêntica e próxima da realidade.

Em sua pesquisa de doutorado, Mayrink (2007) lançou mão de produções cinematográficas com o objetivo descrever e interpretar o fenômeno da formação crítico-reflexiva de professores em formação inicial (alunos de Letras e Pedagogia) mediada por filmes. A partir da perspectiva sociocultural de Vigotski, a autora compreendeu que os filmes se constituem em signos mediadores com potencial para o desenvolvimento crítico-reflexivo do futuro professor.

Souza (2014), em sua tese de doutorado, argumenta que a cultura de aprender e ensinar uma língua estrangeira baseia-se em teorias implícitas que são compostas por fatores como crenças, motivações, memórias, intuições e imagens, dentre outros. Dessa forma, as concepções dos agentes envolvidos na operação global do ensino de línguas exercem profunda influência em todo o processo, já que cada indivíduo, permeado por seu contexto sócio-histórico-discursivo tem suas crenças que embasam as atitudes que norteiam seu comportamento em face do complexo processo de ensino-aprendizagem de línguas.

Diante do exposto, a investigação teve como escopo analisar as crenças de professores de espanhol-língua estrangeira (E-LE) em formação inicial, no que diz respeito ao processo de aquisição/aprendizagem da língua estrangeira e ao tratamento unidade e diversidade linguística experimentada pelo espanhol no contexto do ensino desta língua para brasileiros; todas essas reflexões mediadas pelo cinema. 
Tratou-se de uma pesquisa qualitativa de cunho etnográfico que se iniciou com a compreensão panorâmica do contexto e, a partir de um grupo focal, traçou um levantamento das crenças dos participantes antes, durante e depois das oportunidades de reflexão propiciadas ao longo do semestre 2013.2, de forma a compreender, no processo, como elas se transformavam ou não por meio das atividades de reflexão propostas.

A fundamentação teórica do trabalho esteve ancorada na perspectiva sociocultural, na formação de professores de línguas, na reflexão a respeito das crenças que permeiam o complexo processo de ensino-aprendizagem de línguas e no papel do cinema como artefato semiótico mediador. A experiência reforçou a tese de que o cinema pode contribuir significativamente na formação inicial de professores de espanhol língua-estrangeira promovendo a conscientização linguística a respeito de como se adquire/ aprende a língua, bem como possibilitando o trabalho com a variação linguística no ensino deste idioma para brasileiros a partir do cinema, considerado - conforme a perspectiva sociocultural que adotamos - como artefato cultural, ferramenta de mediação simbólica potencializadora do desenvolvimento humano.

Atualmente, Garcia de Stefani (2014) realiza sua pesquisa de doutorado tendo como temática a formação continuada de professores de inglês e espanhol em serviço com o apoio do cinema, com vistas a fomentar o desenvolvimento e a aplicação em sala de aula de atividades didáticas a partir conteúdo fílmico à luz dos letramentos críticos. 


\section{O exercício da competência intertextual}

Já é consenso entre os estudiosos que quanto mais o espectador de cinema se empenhar em compreender/ analisar os filmes aos quais assiste, maiores serão a chance de se aproximar da intencionalidade e seleção de sentidos pretendidas pelos idealizadores, das características culturais e das ideologias de suas escolhas, permitindo compará-las a sua própria cultura e valores.

Neste sentido, Trevizan (1998, p. 86) aponta que o potencial artístico de um bom filme não se sustenta somente no reconhecimento da credibilidade da história contada, mas reside, sobretudo, na possibilidade de a linguagem criada estabelecer com o espectador um nível profundo de comunicação intelectual, filosófica, psicológica, emocional, fazendo com que ele reflita sobre si mesmo e sobre o outro.

A recuperação do diálogo entre textos diversos, tomando aqui texto no sentido amplo, enriquece a competência intertextual, o que permite que o espectador recupere experiências e leituras anteriores. Mikhail Bakhtin valoriza a interação entre os textos, isto é, o dialogismo do discurso: "a presença de muitas vozes que não se fundem em uma consciência única, mas participam de um dinamismo dialógico" (DI CAMARGO, 2009, p. 32).

O cinema representa uma instância privilegiada de relações dialógicas e intertextuais, de construção ideológica e interação social, devido ao inter-relacionamento das mais variadas modalidades de signos - sistematizados, não apenas pela 
palavra, mas, igualmente, pelo som e pela imagem - na constituição de seu produto final, o texto fílmico (DI CAMARGO, 2009, p. 46).

Todo texto é sempre resultado da uma rede complexa de discursos porque todo sujeito criador está sempre em sintonia cultural com o seu tempo histórico eem sua produção recupera outras experiências de leitura (TREVIZAN, 1998). Para o professor, proporcionar ao aprendiz oportunidades para desvendar a pluralidade contida em um filme pode acrescentar muito ao desenvolvimento global enquanto indivíduo:

a importância da exploração em sala de aula, da natureza intertextual do texto fílmico. Assim, como o texto literário, também o texto fílmico é construído pelo processo dialogante com outros textos. Escritores, pintores, cineastas, artistas em geral dialogam culturalmente, resgatando, nos textos produzidos, o tesouro enciclopédico do já dito (ECO, 1991:22). É possível, portanto, em sala de aula, recuperarmos o diálogo de um filme em análise com outros filmes e também com textos estranhos ao universo cinematográfico (TREVIZAN, 1998, p. 91). 
Levar o cinema para a sala de aula pode implicar em proporcionar aos aprendentes ${ }^{4} \mathrm{um}$ trabalho interdisciplinar que pode ir desde o resgate da história da sétima arte, por exemplo, até o desenvolvimento de conceitos da linguagem cinematográfica que propiciem elementos básicos de análise que permitam ler além das imagens. Dentro da diversidade de obras disponíveis, pode-se trabalhar, com as devidas adaptações, desde dança, música, teatro, literatura, culinária e até mesmo oficinas para os alunos produzirem seus vídeos.

Neste sentido, compartilharemos aqui duas pesquisas das quais participamos e que abordam o exercício da intertextualidade. O trabalho de Souza et. all. (2007) relata uma investigação desenvolvida com alunos do $5 .^{\circ}$ ano do ensino fundamental de uma escola pública do interior paulista. Na ocasião, tivemos como objetivo principal compreender o ponto de vista dos alunos acerca da percepção da intertextualidade entre os clássicos da literatura infantil (Branca de Neve e os setes anões, Cinderela e a Bela Adormecida) e o filme Shrek (2001).

A experiência envolveu a leitura e dramatização dos clássicos, seguida pela comparação dos contos infantis e da análise dos elementos que constituem o gênero. Na sequência, houve a projeção do filme e o levantamento das relações entre o filme e as histórias. Na ocasião, verificou-se a recuperação do diálogo entre o filme com os contos trabalhados, bem como a relação entre as questões tratadas e a realidade dos alunos envolvidos.

4 Termo utilizado por Shulman (1986) apud Brzezinski (2002, p.2) para designar aquele ser que aprende como autor de sua própria aprendizagem. 
O artigo de Souza \& Bongestab (2012) mostra que, ao tomar o cinema como arte e entretenimento, também existe a possibilidade de significá $\square$ lo como ferramenta e prática social propícios para o exercício da intertextualidade. Nele, exploramos a presença das "muitas vozes" que compõem a produção cinematográfica de Carlos Saura, um diretor de cinema e escritor multifacetado, que entrelaça literatura, pintura, dança, música, fotografia, teatro, em suas obras.

\section{Considerações}

Os possíveis diálogos entre a arte cinematográfica e a educação foi o fio condutor no trajeto que traçamos neste texto. Destacamos a capacidade da sétima arte para representar a vida em seus múltiplos aspectos, enfatizando o potencial representacional das inquietações e desejos mais íntimos da alma humana. Tecemos considerações acerca das várias vias de estudo com vistas à compreensão do cinema, com foco na indústria, nas artes, nas invenções, no entretenimento e ressaltamos seu potencial na formação de novas gerações.

A partir de visões múltiplas e ao mesmo tempo complementares, isto é, tomando o texto fílmico como arte, entretenimento, ferramenta e prática social traçamos reflexões acerca da sociedade contemporânea submersa em imagens, sons e movimentos, discorremos sobre os vários usos do cinema e vídeo na escola, apresentamos a pesquisa em educação com base nas artes, bem como as contribuições da prática cineclubista para a formação humana e a importância da sétima arte no exercício da competência intertextual. 
Ao longo de cada item relatamos pesquisas e trabalhos que expandem as questões aqui apresentadas de forma a ilustrar a riqueza da sétima arte, que em sua composição incorpora várias das outras manifestações artísticas experimentadas pelo ser humano e nos coloca diante do desafio de promover via ensino, pesquisa e extensão a arte de ver objetivando leituras plurais do mundo.

\section{Referências}

ADAMSON, A. \& JENSON, V. (Dir.) Shrek. DVD: EUA, 2001.

ALMEIDA, M.J. A linguagem na nova oralidade: imagens e sons In: Coletânea Lições com cinema. São Paulo: FDE, 1994, p. 117-124.

ALVES, G. "O cinema como experiência crítica: tarefa política do novo cineclubismo no século XXI". In: ALVES, G.; MACEDO, F. Cineclube, cinema \& educação. (Orgs.) Londrina: Praxis, Bauru: Canal 6, 2010.

ANDRADE, J.B. Cineclube, Cinema e Educação. In: ALVES, G.; MACEDO, F. (Orgs). Cineclube, cinema \& educação. Londrina/Bauru: Praxis/Canal 6, 2010.

BRZEZINSKI, I (Org.). Profissão professor: identidade e profissionalização docente. Brasília: Plano Editora, 2002.

DENZIN, N. K. The many faces of emotionality. In: ELLIS, C.; FLAHERTY, M. G. (Eds.). Investigating subjectivity. Newbury Park, CA: Sage Publications, 1992. 
DI CAMARGO, I.J. A Memória de Futuro analisada pela Linguagem Cinematográfica: Diálogos entre a Teoria do Cinema e Mikhail Bakhtin. Dissertação (Mestrado em Linguística). São Carlos: UFSCar, 2009.

DIAMOND, C. T. P.; MULLEN, C. A. The postmodern educator: arts-based inquiries and teacher development. New York: Peter Lang, 1999.

EISNER, E. W. The enlightened eye. New York: Macmillan Publishing Company, 1991.

EISNER, E. W. "The promise and perils of alternative forms of data representation". Educational Researcher, v. 26, n. 6, p. 4-10, 1997.

FABRIS, E.T.H. Em cartaz: o cinema brasileiro produzindo sentidos sobre escola e trabalho docente. Tese (doutorado em educação). Porto Alegre: UFRGS, 2005.

GRAY, R. E. Performing on and off the stage: the place(s) of performance in arts-based approaches to qualitative inquiry. Qualitative Inquiry, v. 9, n. 2, p. 254-267, 2003.

MAYRINK, M.F. Luzes... câmera... reflexão: formação inicial de professores mediada por filmes. Tese (doutorado em Linguística Aplicada e Estudos da Linguagem). São Paulo: PUC, 2007.

MACEDO, F. Cineclube e autoformação do Público. In: ALVES, G.; MACEDO, F. (Orgs). Cineclube, cinema \& educação. Londrina/Bauru: Praxis/Canal 6, 2010. 
MORAN, J.M. O vídeo na sala de aula. Comunicação $\mathcal{E}$ Educação. São Paulo: ECA/Ed. Moderna. Jan./abr. 1995, n. 2, pp. 27-35.

MORAN, J.M. Os vários usos do cinema e de vídeo na escola In: NAPOLITANO, M. Como usar o cinema na sala de aula. São Paulo: Contexto, 2003.

MORAES, A. C. A escola vista pelo cinema: uma proposta de pesquisa. In: Maria da Graça Jacintho Setton. (Org.). A cultura da mídia na escola: ensaios sobre cinema e educação. 1 ed. São Paulo: Annablume/USP, 2004, v. 1, p. 53-66.

NAPOLITANO, M. Como usar o cinema na sala de aula. São Paulo: Contexto, 2003.

PINHEIRO, S.R.L. Educação, memória e cinema: um estudo comparativo das representações sociais da escola em "Os incompreendidos" e em "Machuca". Dissertação (mestrado em educação). São Paulo: USP, 2010.

SOUZA, F.M.; BONGESTAB, C. Texto fílmico: imagem e intertextualidade. In: SOUZA, F.M.; GHAZIRI, S.M. (Orgs.). Pesquisa e ensino de leitura no mundo atual: debates múltiplos. São Carlos: Pedro \& João Editores, 2012, v. 1, p. 18-37.

SOUZA, F.M.; CRUZ, M.L.O.B.; GAMA, A.P.F. “O cinema no aperfeiçoamento das competências do aprendiz de línguas (materna e estrangeira)". In: PINHO, S.Z.; SAGLIETTI; J.R.C. (orgs.) Núcleos de Ensino - Projetos de 2005. São Paulo: Cultura Acadêmica/UNESP Publicações, 2007. pp. 487-499. 
TELLES, J.A. Pesquisa educacional com base nas artes: pensando a educação dos professores como experiência estética. In: Educação e Pesquisa (USP), vol.32, n. ${ }^{\circ}$ 3, 2006, pp.509-530.

TELLES, J.A. Modos de representação: o espetáculo teatral como dispositivo de reflexão e representação do desenvolvimento do professor. In: VIEIRA-ABRAHÃO, M.H. (Org.) Prática de ensino de língua estrangeira: experiências e reflexões. Campinas: Pontes Editores, ArteLíngua, 2004.

TREVIZAN, Z. As malhas do texto: escola, literatura, cinema. São Paulo: Clíper, 1998.

TURNER, G. Cinema como prática social. São Paulo: Summus, 1997

VERTOV, D. O Homem da Câmera (Chelovek s Kinoapparatom) (1929). Disponível em: Utorrent Download. 


\title{
O GÊNERO CURTA METRAGEM COMO OBJETO DE ENSINO E APRENDIZAGEM DA LEITURA E DA PRODUÇÃO TEXTUAL
}

\author{
Jeane dos Santos ${ }^{1}$ \\ Roseane B. Feitosa Nicolau ${ }^{2}$
}

\section{Introdução}

A inserção de recursos audiovisuais no contexto educacional não é novidade, como afirma a autora do livro Educação, imagem e mídias, Costa (2013). De modo que, no início do século $\mathrm{XX}$, documentários de curta e média metragem eram utilizados como apoio às práticas educativas. Entretanto, no contexto das aulas de língua portuguesa, ainda é incipiente essa inserção dos vídeos como apoio às práticas educativas e ao ensino da língua, uma vez que os métodos e estratégias de leitura e de escrita

1 Formada em Letras pela UEPB (2007), especialista em Literatura e Cultura Afro-Brasileira e Africana também pela UEPB (2011), mestra em Letras pela UFPB (2018). Atua como professora de Língua Portuguesa na Rede Municipal de Jacaraú-PB e de Duas Estradas-PB. (enaejsantos@hotmail.com )

2 Graduada em Letras (Português e Francês), Mestra em Letras (2002) e Doutora em Linguística (2008) pela UFPB. Professora da UFPB do Curso de Letras do Campus IV, do PROFLETRAS (Programa de Mestrado Profissional em Letras ) e do MPLE (Mestrado Profissional em Linguística e Ensino). (rosenicolau. ufpb@gmail.com) 
contemplam o conceito limitado de texto linear e a imagem ainda é vista como suporte ilustrativo do texto escrito, como uma representação sem merecer interpretações, compreensão e interação.

Uma ferramenta importantíssima de apoio ao professor, que acredita no potencial de vídeos de curta-metragem e que deseja inseri-los no ambiente escolar, é o portal Curta na Escola. No entanto, não basta dispor os vídeos no ambiente escolar, seja de forma física ou virtual. É preciso que o professor esteja preparado, ou pelo menos queira estar, para utilizá-lo de forma criativa e responsável, para a promoção da aprendizagem. É no tocante a este ponto - a ação do professor - que se apresenta a nossa proposta, a qual propõe o trabalho em sala de aula com curtas-metragens como objeto de ensino e de aprendizagem em aulas de língua portuguesa, especificamente com turma dos últimos anos do Ensino Fundamental.

A partir da exploração do curta-metragem (gênero multimodal), esperamos que os alunos adquiram a capacidade de compreensão do modo como os textos, nas novas tecnologias, operam e utilizem o que foi aprendido, significando, por meio da leitura, e ressignificando, por meio da escrita, para realizar, assim, uma prática transformadora na qual se tornam agentes letrados.

Acreditamos que o estudo da linguagem cinematográfica pode se mostrar bastante produtivo na tarefa de capacitar os alunos a lidarem com o texto multimodal, inserindo-os, portanto, no multiletramento. Ao introduzir o curta-metragem no currículo, a escola assume como uma de suas funções sociais pensar o cinema para além do entretenimento, como um elemento social e cultural de modo reflexivo e crítico. E isso implica reconhecer o poder 
informacional e formador dessa linguagem, capaz de proporcionar a assimilação e a compreensão de certas ideias, valores e conceitos que seriam difíceis de outra forma; assim, reforçamos o caráter pedagógico do curta.

A partir dessa abordagem multimodal da linguagem, por meio do curta, faz-se mister uma concepção de letramento que dê conta dessa dinamicidade da linguagem e, para isso, propomos um trabalho de leitura e de escrita sob a ótica do multiletramento.

Devemos salientar que, ao escolher utilizar os curtas como objeto de ensino e de aprendizagem da leitura e da escrita em sala de aula, baseamo-nos na Base Nacional Comum Curricular (doravante BNCC), que entrou em vigor em 2017 e norteará a elaboração de currículos, quando postula, ao tratar do estudo da língua, que
o componente Língua Portuguesa cabe, então, proporcionar aos estu- dantes experiências que contribuam para a ampliação dos letramentos, de forma a possibilitar a participação significativa e crítica nas diversas práticas sociais permeadas/constitu- ídas pela oralidade, pela escrita e por outras linguagens (BRASIL, 2017, p. 65-66, grifo dos autores).

Essa escolha ainda teve apoio nas ideias de Moran (2005, p. 36), quando afirma que a

educação escolar precisa compreender e incorporar mais as novas linguagens, desvendar os seus códigos, 
dominar as possibilidades de expressão e as possíveis manipulações. É importante educar para usos democráticos, mais progressistas e participativos das tecnologias que facilitem a educação dos indivíduos.

Além disso, há um gama de produções midiáticas que poderiam servir a essa educação democrática, que considera as múltiplas linguagens levando o aluno a constituir-se como sujeito linguisticamente competente. Entre essas produções estão os curtas-metragens. Assim, ao falar sobre as potencialidades educacionais dos meios eletrônicos

[é] premente que se instaure o debate, a implantação de políticas e estratégias para o desenvolvimento e disseminação de propostas de trabalho inovadoras utilizando os meios eletrônicos de informação e comunicação, já que eles possuem um enorme potencial educativo para complementar e aperfeiçoar o processo de ensino e aprendizagem (BRASIL, 1998a, p. 142).

Logo, cabe ao professor planejar, implementar e orientar as atividades didáticas de modo que o trabalho com curtas, possam fazer parte das atividades das aulas de língua portuguesa, consoante com Conceitos e Procedimentos Subjacentes às Práticas de Linguagem dos PCN (BRASIL, 1998b). Vemos os conteúdos e significações 
dos curtas como modos de perceber a realidade, de aprender, de produzir e de difundir conhecimentos, informações e ideologias.

Para isso, selecionamos o curta Selfie com o gato ${ }^{3}$, uma produção estrangeira que aborda um tema atual, apresentando questões sociais reais, vivenciadas pelos jovens; e partimos para a proposta de ensino e aprendizagem da leitura e da produção textual, a partir de curtas-metragens, apresentando como objetivos teórico-metodológicos: construir uma concepção de curta-metragem como elemento de ensino e aprendizagem, defendendo sua viabilidade como recurso pedagógico multimodal; e, efetivar a aplicação da linguagem cinematográfica e a narrativa de curta-metragem no ensino, desenvolvendo um trabatho de leitura e de escrita de curta, levando em conta os elementos multimodais para a construção do sentido do texto.

Comecemos, então, pela construção uma da concepção de curta-metragem, sua composição, estrutura e, por fim, sua aplicação no ensino.

\section{Curta-metragem: conceito e aplicação no ensino}

O curta-metragem, ou curta na linguagem informal, é um termo vindo do francês court-métrage, refere-se a um filme de curta duração que dura trinta minutos ou menos. Segundo o Dicionário Houaiss (2009, p. 588), que ratifica essa duração máxima de trinta minutos, ele possui "intenção estética, informativa, educacional ou

3 Título original: Selfie cat (tradução nossa) 
publicitária, ger. exibido como complemento de um programa cinematográfico".

O surgimento do curta-metragem tem como marco o nascimento do cinema no final do século XIX, quando os irmãos Auguste e Louis Jean Lumière, filhos do fotógrafo Antoine Lumière, fizeram a primeira exibição em público em 28 de dezembro de 1895, no Grand Café, localizado na capital francesa. Esses primeiros filmes apresentavam entre quarenta e cinquenta segundos e, com a ampliação desse tempo, chegou-se à duração de setenta minutos, em 1906, com o primeiro longa-metragem do cinema mundial The Story of the Kelly Gang ${ }^{4}$, de origem australiana.

Como explica Alcântara (2014, o conceito de curta-metragem era associado "a uma limitação técnica. Dessa forma, a produção de curtas não era uma questão de escolha de seus produtores; ao contrário, tratava-se da única forma possível de realização cinematográfica naquele momento embrionário das produções cinematográficas".

Por conseguinte, para diferenciar esses vídeos de tamanhos variados, houve a necessidade da adjetivação, ou seja, começou-se a diferenciar o filme "curto" (short film) do filme (film), isto é, do filme "longo" (feature film), ou melhor, o curta-metragem do longa-metragem. Porém, ambos integram a Sétima Arte - o cinema.

No entanto, podemos afirmar que os filmes, inseridos na categoria de curta têm se adaptado às mudanças contemporâneas. Por exemplo, com a explosão das redes, não é novidade que os usuários compartilhem vídeos cada vez menores, muitos dos quais não ultrapassam 15 segundos.

4 A História da Gangue Kelly (tradução nossa). 
Estrutura do curta: narrativa e elementos cinematográficos

Ao tratar dos filmes de curtas-metragens, os estudiosos franceses Vanoye e Goliot-Lété (2014, p. 110) afirmam que eles "exibem seus dispositivos (narrativos ou discursivos), sua estrutura dramática e rítmica, a forma-sentido que produz seu impacto de maneira mais evidente que os longas-metragens". E explicam que isso acontece porque possivelmente não há tempo para esses elementos serem apreendidos, de modo que essa exibição acontece de forma "rápida, aguda, como se 'precipitassem".

Ribeiro (2013) afirma que, devido a esse curto tempo de duração, os curtas-metragens apresentam as seguintes características:

reduzido número de personagens e diálogos; condensação narrativa [...]; tempo da história, na maioria dos casos, linear; guiões verossímeis; grande carga emotiva e sugestiva e final, geralmente, surpreendente; pela sua natureza cinematográfica, veicula conteúdos culturais, socioculturais, transmite valores educativos e traduz-se numa rentável fonte para trabalhar aspectos interculturais (RIBEIRO, 2013, p. 21-22).

Isso significa que a dinamicidade desse tipo de narrativa multimodal apenas agrega valores e ratifica a importância de sua utilização no ambiente escolar, bem como a sua viabilidade. Ou seja, valores são agregados, a partir da possibilidade de contar histórias, mesmo com poucas 
personagens e quase nenhum diálogo, mas com roteiros capazes de aflorar as emoções e sensibilidades de nossos alunos. A sua importância deve-se à necessidade de preparar os nossos discentes para atribuírem sentidos aos textos multimodais que envolvam temáticas socioculturais, valores educativos, enfim, que sejam relevantes para a vida em sociedade.

Ainda, quanto à celeridade do filme de metragem curta, Alex Moletta (2009, p. 17) equipara-o "ao conto na literatura ou ao haicai na poesia", ou seja, a história narrada deve ser breve e impactante, mesmo sendo dramática ou cômica não deve haver tempo nem espaço para discursos vazios. Portanto, "a precisão, a coerência, a densidade e a unidade de ação" são as principais características desse formato de cinema.

Logo, o realizador do curta-metragem precisa selecionar imagens que narrem o que acontece; que elas, além de estarem de acordo com o que foi proposto, revelem os conflitos a serem solucionados, apresentando ligação direta com o tema ou conflito principal, como explica o autor. Ele ainda esclarece "que cinema é a arte da imagem e não do diálogo" (MOLETTA, 2009, p. 18), isto significa que é preciso utilizar a imagem de forma narrativa.

Sobre essa arte, Costa (2013, p. 95) lembra que após as pinturas parietais da pré-história, a pintura e o desenho também enfrentaram o desafio de "imprimir graficamente a ideia do tempo, do movimento e da narratividade". Portanto, com o surgimento e a difusão da indústria cinematográfica, além de entretenimento, o cinema tornou-se "um meio mágico de se contar histórias" (COSTA, 2013, p. 99). 
Nesse sentido, o cerne do cinema é a imagem em movimento. Essa imagem pode ser narrada com diferentes planos; o movimento pode ser panorâmico, travelling ou resultante destes dois; o ângulo da câmera pode ser horizontal, alto ou baixo; a imagem pode ser acompanhada da linguagem verbal escrita e/ou falada. Convém ressaltar que todos esses recursos foram descobertos paulatinamente, às vezes de maneira até acidental.

Segundo Jean-Claude Bernardet (2004, p. 33), "a criação de estruturas narrativas e a relação com o espaço" foram dois elementos essenciais dessa gramática cinematográfica, e o autor cita a diferença entre a produção norte-americana e a alemã. A primeira estava preocupada com uma linguagem transparente, isto é, uma narrativa que priorizava o enredo, as emoções dos personagens, de modo que a atenção do espectador se voltasse para o que é narrado como um fragmento da realidade, sem provocar estranhamento.

É possível compreender melhor a estrutura de um audiovisual por meio de análises, pois, como afirmam Vanoye e Goliot-Lété (2014), analisar um filme implica descrever os elementos constitutivos deste para em seguida reconstruí-lo ${ }^{5}$. Ou seja, é preciso individualizar cada elemento para, em seguida, estabelecer conexões, atribuir sentidos.

5 Os autores esclarecem que analisar um filme "significa duas coisas: a atividade de analisar [...]; e também pode significar o resultado dessa atividade[.]" (VANOYE; GOLIOT-LÉTÉ, 2014, p. 14). Neste trabalho, nosso propósito é tratarmos da primeira, isto é, a atividade de análise. 
Portanto, decompor as partes de um filme significa:

despedaçar, descosturar, desunir, extrair, separar, destacar e denominar materiais que não se percebem isoladamente "a olho nu", uma vez que o filme é tomado pela totalidade. Parte-se, portanto, do texto fílmico para "desconstruí-lo" e obter um conjunto de elementos distintos do próprio filme (VANOYE; GOLIOTLÉTÉ, 2014, p. 14-15).

Logo, esse processo de decomposição da estrutura de uma obra cinematográfica é sucedido pela etapa de recomposição:

Uma segunda fase consiste, em seguida, em estabelecer elos entre esses elementos isolados, em compreender como eles se associam e se tornam cúmplices para fazer surgir um todo significante: reconstruir o filme [...]. É evidente que essa reconstrução não apresenta qualquer ponto em comum com a realização concreta do filme (VANOYE; GOLIOT-LÉTÉ, 2014, p. 15).

Esses autores alertam para processos completamente distintos: o processo criativo de elaboração do filme e o estudo deste por outros. Pois, como lembra Mesquita (2006), a "organização" de um enredo e o(s) sentido(s) que 
o texto guarda variam em cada época e geram diferentes significações.

A partir deste momento, passamos a descrever alguns desses elementos incorporados a obras audiovisuais. Para isso, recorremos à obra Como analisar narrativas, de Gancho (2014), que descreve os elementos de uma narrativa de maneira didática. Assim, apresentamos os principais componentes de uma narrativa:

a) Enredo. Corresponde ao encadeado de ações executadas ou a executar pelas personagens, a fim de criar sentido ou emoção no espectador. Gancho (2014) expõe alguns nomes correspondentes ao conjunto dos fatos de uma história, a exemplo de fábula, intriga, ação, trama. Em seguida, apresenta o elemento estruturador das partes, isto é, o conflito que, por sua vez, de forma geral determina a introdução, o desenvolvimento, o clímax e o desfecho da história.

b) Personagens. Elemento integrante da narrativa, a personagem é um ser sempre fictício que só existe se participa ativamente do desenvolvimento do enredo. Não importa se é humano, objeto ou qualquer outro ser, desde que aja na narrativa. Quanto ao papel da personagem no desenvolvimento do enredo, esta pode ser protagonista ou antagonista, caso tenha desempenho principal. Independente de serem mais ou menos participativos, esses seres podem ser planos, apresentam características fixas, ou redondos, quando há uma complexidade maior na atuação e possuem uma variedade maior de características.

c) Tempo. Gancho (2014) lembra que, na ficção, o tempo pode ser considerado em vários níveis. Um deles está 
relacionado à duração da obra, seja ela pode ser curta ou longa. Outro diz respeito à época em que a história se passa, ou seja, a época reproduzida na narrativa, o que pode diferir do tempo real de produção. A princípio, as obras fílmicas empregavam o tempo cronológico, isto é, o enredo linear seguia a ordem natural dos fatos. Porém, com o aprimoramento da linguagem cinematográfica, foi possível alterar a ordem natural dos acontecimentos. Assim, a ordem passou a ser "determinada pelo desejo ou pela imaginação do narrador ou das personagens" (GANCHO, 2014, p. 25), recorrendo-se muitas vezes à técnica do flashback, uma volta no tempo.

d) Espaço/ambiente. Ainda recorrendo ao trabalho de Gancho (2014), encontramos uma distinção entre espaço e ambiente. O primeiro é o lugar físico dos fatos da narrativa. Sobre ele, a professora afirma que "tem como funções principais situar as ações das personagens e estabelecer com eles uma interação, quer influenciando suas atitudes, pensamentos ou emoções, quer sofrendo eventuais transformações provocadas pelas personagens" (GANCHO, 2014, p. 27). Assim, a importância do espaço é evidenciada à medida que o ser fictício do enredo é influenciado por ele e, por sua vez, também o modifica.

e) Narrador. Diferente do autor, o narrador é uma criação ficcional que assume uma posição diante dos fatos narrados. Basicamente existem dois tipos de narrador: aquele que narra os fatos sem participar deles, denominado narrador observador; e, aquele que participa da história como qualquer outra personagem, o que justifica a classificação de narrador personagem. 
Para entendermos a estrutura de um curta-metragem, acreditamos ser útil o modelo de Michel Marie (1975), registrado na obra Ensaio sobre a análise fílmica, de Vanoye e Goliot-Lété (2014). O modelo apresenta parâmetros a serem considerados na primeira etapa de análise de um produto audiovisual, isto é, na fase de descrição dos elementos constituintes da obra:

1. Numeração do plano, duração em segundos ou número de fotogramas.

2. Elementos visuais apresentados.

3. Escala dos planos, incidência angular, profundidade de campo, objetiva utilizada.

4. Movimentos:

4.1 no campo, dos atores ou outros;

4.2 da câmera.

5. Raccords ou passagens de um plano a outro: olhares, movimentos, cortes, fusões ou escurecimentos, outros efeitos.

6. Trilha sonora: diálogos, ruídos, música; escala sonora; intensidade; transições sonoras, encavalamentos, continuidade/ruptura sonora.

7. Relações sons/imagens: sons in/off/ fora de campo; sons diegéticos ou extradiegéticos, sincronismo ou assincronismo entre imagens e sons (VANOYE; GOLIOT-LÉTÉ, 2014, p. 65-66).

No entanto, para identificar esses elementos em um vídeo, que vimos como essencial no nosso trabalho de intervenção da leitura dos curtas-metragens, por serem 
elementos que se integram na construção do sentido, da mensagem do curta, torna-se necessário um conhecimento básico da linguagem cinematográfica. Porém, como lembra Napolitano (2015), o professor para trabalhar filmes não precisa ser crítico profissional do cinema.

Para os principiantes neste tipo de gramática, provavelmente a obra de Alex Moletta (2009), Criação de curta-metragem em vídeo digital, possa auxiliá-los; pois, além de empregar uma linguagem bastante acessível, conceitua esses elementos à medida que aborda cada etapa de elaboração do audiovisual: roteiro, direção, fotografia, produção, montagem e finalização.

Juntamente com essa obra que trata da linguagem técnica podemos indicar o site Curta na Escola, sobre o qual falamos no início deste trabalho, em que vídeos curtos podem ser baixados ou usados on-line. Uma das vantagens é que esses vídeos pedagógicos disponibilizados são acompanhados por plano(s) de aula que orienta(m) o trabalho com diversos conteúdos a partir de um curta-metragem. Assim, após conhecer um pouco sobre a gramática da cinematografia é possível ampliar as possibilidades interpretativas de um filme.

Ainda sobre o livro de Moletta (2009), encontramos uma breve apresentação de vários elementos cinematográficos, inclusive daquele que é um intermediário entre o roteiro e a execução dele: o storyboard.

Por meio do storyboard pode-se conta uma história agregando fatores multimodais: o contexto em que se insere a história, a interação entre as personagens e a ideia de tempo. Elementos essenciais da narrativa bastante explorados hoje pelo cinema e que precisam ser lidos e compreendidos pelos alunos. 
O storyboard pode tornar-se uma etapa que antecede a escrita do texto, um elemento que favorece o planejamento do que vai ser dito na forma escrita, no caso da sala de aula; um guia visual narrando as principais cenas de uma história de forma progressiva. Esse guia pode permitir uma melhor preparação para a produção textual.

\section{Curta-metragem e sua aplicação no ensino e aprendizagem da leitura e da escrita}

Este subtópico tem como base teórica a visão da BNCC que dialoga com documentos e orientações curriculares produzidos nas últimas décadas. Este documento, no Eixo Leitura, um dos quatros que integram a BNCC de Língua Portuguesa, ratifica um conceito amplo de leitura, que não se limita ao texto escrito ou oral, mas também aos textos multissemióticos. Isto é, no contexto da BNCC, tanto o texto escrito, quanto as imagens estáticas ou em movimento, assim como o som são passíveis de leitura. Assim, contempla-se o que nos defendemos: um trabalho com a leitura a partir de curta-metragem:

O Eixo Leitura compreende as práticas de linguagem que decorrem da interação ativa do leitor/ouvinte/ espectador com os textos escritos, orais e multissemióticos e de sua interpretação, sendo exemplos as leituras para: fruição estética de textos e obras literárias; pesquisa e embasamento de trabalhos escolares e acadêmicos; realização de procedimentos; conhecimento, discussão 
e debate sobre temas sociais relevantes; sustentar a reivindicação de algo no contexto de atuação da vida pública; ter mais conhecimento que permita o desenvolvimento de projetos pessoais, dentre outras possibilidades (BRASIL, 2017, p. 69).

A leitura, neste contexto, é vista como uma atividade que constrói sentidos a partir da interação autor-texto-leitor, de modo que é necessário considerar o autor e o seu contexto de produção, assim como o texto e suas especificidades, além dos saberes e interesses do leitor.

Em relação à leitura de um texto multissemiótico, a exemplo de um curta-metragem, Moran (1995) indica alguns procedimentos didáticos que devem ser executados antes, durante e após a exibição do vídeo: a) informar aspectos gerais, tais como autor, duração, prêmios recebidos entre outros do vídeo; b) durante a exibição, anotar as cenas mais relevantes; se necessário, pausar o vídeo para fazer comentários, e observar as reações dos espectadores, e, por fim, c) retornar ao início do vídeo; rever as cenas mais significativas ou difíceis; passar quadro a quadro as imagens mais importantes; observar o som (música, efeitos, diálogos).

Depois desse processo de leitura que deve ser realizado pelos alunos e pelo professor de modo individual, Moran (2005) propõe algumas dinâmicas de análise do vídeo, de socialização das leituras individuais e suas reelaborações. Resumimos as propostas de análises de Moran a seguir: 
a) Análise em conjunto: conversar sobre as cenas mais importantes em que o professor deve posicionar-se depois dos alunos.

b) Análise globalizante: relato de aspectos positivos e negativos do vídeo, além das ideias principais e do que seria mudado. Após destacar coincidências e divergências, o professor faz a síntese final.

c) Leitura concentrada: após rever cena(s) marcante(s), questionar seus significados e aplicações para a vida, e o que se destaca mais (imagem, som ou palavra).

d) Análise "funcional": antes de exibir o vídeo, distribuir tarefas entre os alunos, tais como contar cenas, caracterizar personagens, anotar palavras-chave. Depois da exibição, registram-se no quadro as respostas, e professor e alunos completam as informações.

e) Análise da linguagem: expor a história contada e como ela é contada, bem como ideias e ideologias apresentadas.

f) Completar o vídeo: desenvolver um final para um vídeo que é exibido parcialmente e, após a exposição, comentá-lo.

g) Modificar o vídeo: editar um vídeo.

h) Videoprodução: narrar em vídeo um determinado assunto.

i) "Vídeo-espelho": observar e comentar o desempenho quando se é filmado pela câmera.

j)Videodramatização: a partir do vídeo assistido, dramatizar situações/personagens adaptadas à realidade dos alunos.

k) Comparar versões: comparar uma obra literária com sua adaptação cinematográfica, destacando pontos fortes e fracos em ambas as obras. 
Nas palavras de Indursky e Zinn (1985), a produção textual é desencadeada pela produção de leitura e se encerra ainda, com a leitura do sujeito-autor, o primeiro a ler o texto. As autoras esclarecem que "a leitura como suporte para a produção textual" possibilita ao indivíduo "exercer-se criticamente, interagir com o mundo, produzindo seus próprios textos" (1985, p. 27). Em outras palavras, a produção textual é antecedida pela produção de leitura, e esta

consiste no processo de interpretação, desenvolvido por um sujeito-leitor que, defrontando-se com um texto, analisa-o e questiona-o com o objetivo de processar seu significado, projetando sobre ele sua visão de mundo para estabelecer uma interação crítica com o texto (INDURSKY; ZINN, 1985, p. 24).

De acordo com as autoras, o aluno consegue ler criticamente quando há uma relação dinâmica com o professor, de modo que eles estabeleçam trocas entre si e se enriqueçam mutuamente, ou seja, tanto o aluno quanto o professor exercem alternadamente a função de sujeito diante do texto. Acreditamos que as dinâmicas de análise de vídeo na escola sugeridas por Moran possibilitam esse tipo de leitura.

Ainda de acordo com Indursky e Zinn (1985) essa produção de leitura é possível a partir de três etapas: leitura compreensiva, leitura interpretativa e leitura crítica. Estas etapas estão dispostas numa ordem de crescente 
complexidade. A primeira fase objetiva a apreensão do texto em sua globalidade, é o que Solé (2012) denomina de leitura para obter uma informação de caráter geral.

A próxima etapa, leitura interpretativa, por meio de um processo analítico, objetiva a descontextualização e recontextualização do texto, para revelar seus significados. É nesta fase que o texto é analisado em suas relações textuais, contextuais e intertextuais. No caso de um curta-metragem, é em relação aos elementos textuais que se fará uma análise da linguagem cinematográfica. É quando possível, segundo Vanoye e Goliot-Lété (2014), descrever os elementos constitutivos de um filme para em seguida reconstruí-lo. Essa leitura interpretativa tem o propósito de ler para aprender, logo, o leitor é levado "a se interrogar sobre o que lê, a estabelecer relações com o que já sabe, a rever os novos termos, a efetuar recapitulações e sínteses frequentes, a sublinhar, a anotar" (SOLÉ, 2012, p. 95).

Na última etapa do modelo proposto por Indursky e Zinn (1985, p. 24), a partir do conhecimento aprofundado sobre um texto é possível "estabelecer conclusões acerca da intencionalidade do texto e da ideologia que lhe subjaz". Consequentemente, o sujeito-leitor é capaz de posicionar-se criticamente sobre o texto, finalizando, desse modo, o ciclo de sua produção de leitura, o qual é pré-requisito básico para a produção textual.

A produção textual divide-se em planejamento e execução. Quanto ao planejamento, há quatro etapas: delimitação do tema; definição do posicionamento do sujeito-autor e de sua intencionalidade; seleção de ideias e argumentos; esquema com ideias e argumentos organizados. Na fase de execução, há a produção do texto-processo sob o enfoque do conteúdo e da forma; e, por último, a análise da 
produção textual de acordo com a organização das ideias, coerência e coesão dos recursos utilizados. E ao término, teremos o texto-produto. Nas palavras das autoras, a

[...] produção textual vem a ser a situação em que o sujeito-autor realiza a contextualização de idéias e argumentos que se inter-relacionam, num arranjo pessoal, apresentando organização e coerência, com o objetivo de produzir um texto que revele seu posicionamento (INDURSKY; ZINN, 1985, p. 26).

O texto deve ser entendido "como uma unidade significativa complexa, de natureza não apenas linguística, mas comunicacional, na qual intervêm elementos contextuais em sentido amplo" (INDURSKY; ZINN, 1985, p. 23).

Complementando essa visão, a BNCC de Língua Portuguesa, traz que o Eixo da Produção de Textos

compreende as práticas de linguagem relacionadas à interação e à autoria (individual ou coletiva) do texto escrito, oral e multissemiótico, com diferentes finalidades e projetos enunciativos como, por exemplo, construir um álbum de personagens famosas, de heróis/heroínas ou de vilões ou vilãs; [...] descrever, avaliar e recomendar (ou não) um game em uma resenha, gameplay ou vlog; [...] cobrir acontecimentos ou levantar 
dados relevantes para a comunidade em uma reportagem; expressar posição em uma carta de leitor ou artigo de opinião; denunciar situações de desrespeito aos direitos por meio de fotorreportagem, fotodenúncia, poema, lambe-lambe, microrroteiro, dentre outros (BRASIL, 2017, p. 74).

De acordo com o trecho acima, percebemos claramente a diversidade de gêneros discursivos/textuais e os multiletramentos contemplados pela BNCC. Nas circunstâncias atuais, tratar de leitura e produção textual sem considerar toda a diversidade e necessidade de uso das multissemioses é inadmissível. O ensino da leitura e da produção textual deve atender às necessidades sociais, as quais não são estáticas, mas reelaboradas constantemente.

Os multiletramentos requerem novas práticas de produção - seja a escrita, o áudio, o vídeo, o tratamento de imagem, a edição e a diagramação - bem como de análise crítica como receptor.

Diversos pesquisadores da área dos estudos linguísticos, dentre eles Dionísio (2011), Rojo e Barbosa (2015), vêm discutindo formas de utilização da modalidade visual nas práticas de escrita e utilizando nestes estudos, um novo conceito de modalidade de textos: os textos multimodais. Esses textos multimodais, conforme Rojo (2012) são compostos de muitas linguagens (ou modos, ou semioses) e exigem multiletramentos para fazer significar, isto é, requerem capacidades e práticas de compreensão e produção de cada uma dessas linguagens.

As práticas escolares educativas no contexto dos estudos linguísticos, devem proporcionar aos alunos a análise 
de textos que circulam socialmente, dentre estes, o audiovisual, o filme, o curta-metragem. A inclusão de vídeos em aulas de língua portuguesa pode possibilitar a ampliação dos limites da aprendizagem formal.

Além disso, a escola pode e deve orientar o aluno a fazer leituras eficientes, uma vez que não basta ver, é preciso saber assistir a filmes e vídeos, aprender a ler as partes e atingir uma compreensão global, do todo, como afirmam Vanoye e Goliot-Lété (2014) ao abordarem a análise fílmica. Portanto, é necessário ensinar os alunos a lerem, não apenas as palavras, mas também a lerem as imagens, os movimentos, os sons, os silêncios, as cores e os planos.

Como lembra Costa (2013), as imagens cada vez mais povoam a sociedade e ratificam a importância de educar o olhar e desenvolver a leitura de imagens. A autora explica que

a opção por uma educação que valoriza a educação pela e para a imagem não se faz em nome de uma ação pedagógica menos disciplinada ou mais espontaneísta, mas em busca de um entendimento mais afetivo do mundo e de uma comunicação mais abrangente e inclusiva (COSTA, p. 2013, p. 38).

Costa acrescenta, ainda, que a linguagem visual é mais inclusiva em relação à escrita, uma vez que não impõe barreiras intransponíveis entre as imagens e os observadores, tornando-se, dessa forma, mais igualitária e acessível. 
É importante reforçar que este trabalho não trata da valorização de uma ou outra modalidade da linguagem, mas da inclusão delas também na formação escolar do cidadão letrado. Como ratifica Dionisio (2011, p. 139), trata-se da harmonia visual estabelecida entre imagem e palavra, uma vez que "a multimodalidade é um traço constitutivo do discurso oral e escrito".

Além das semioses dos textos, devemos lembrar que os multiletramentos também incluem a multiculturalidade. A autora Rojo (2012) cita Canclini (2008), para quem "a produção atual se caracteriza por um processo de desterritorialização, de descoleção e de hibridação que permite que cada pessoa possa" inovar, principalmente a partir das novas tecnologias (apud ROJO, 2012, p. 16). Assim, nesse cenário globalizado, os limites que distanciam uma produção textual de outra - seja vídeo, poema, reportagem, etc. - são cada vez mais tênues.

É óbvio que o desenvolvimento da tecnologia tem contribuído com a expansão dos multiletramentos, tanto nas possibilidades de combinações de modalidades quanto na aproximação sociocultural entre grupos diversos. Contudo, é importante não esquecer, como afirma Masetto (2005), que a tecnologia é um instrumento que pode auxiliar no desenvolvimento da aprendizagem, no entanto, "ela somente terá importância ser for adequada para facilitar o alcance dos objetivos e se for eficiente para tanto" (MASETTO, 2005, p. 144). Acreditamos que é possível promover o desenvolvimento da aprendizagem em aulas de língua portuguesa por meio dessas tecnologias.

Como prática, damos como exemplo o estudo do vídeo Selfie com o gato. produzido na França, que tem como tema o selfie, como elemento de exibicionismo. Nesse estudo, 
procuramos explorar, de forma significativa e responsável, a linguagem e a narrativa de curta-metragem, desenvolvendo um trabalho de leitura e de escrita, considerando os elementos multimodais para a construção do sentido do texto.

\section{Proposta de leitura e produção textual a partir do curta Selfie Cat}

Apresentamos a seguir uma proposta, constituída por dois momentos pedagógicos, nos quais o curto Selfie Cat foi tomado como norteador de atividades, tentando construir uma concepção de curta-metragem como elemento de ensino e aprendizagem, defendendo sua viabilidade como recurso pedagógico multimodal.

O curta Selfie com o gato é muito dinâmico por apresentar uma multiplicidade de linguagens (visual, gestual, sonora, cinética) e, também, por apresentar um tema presente no cotidiano dos adolescentes - o que aumenta as possibilidades de ele ser mais bem aceito pelos alunos do Ensino Fundamental. Este curta foi produzido em 2016, dirigido por Elsa Divet, Emiline Bernard e Geoffrey Assie e pertencente ao gênero animação comédia. Narra-se neste curta a situação em que uma menina tenta tirar uma selfie com seu gato para disputar popularidade na Internet. Antes de iniciar a exibição do curta-metragem é bom expor essas informações sobre o vídeo, como propõe Moran (1995).

Este curta, como qualquer outro texto, é passível de leitura. Sendo assim, pode-se sondar os níveis de leitura realizada pelos alunos, bem como realizar uma produção textual a partir da leitura do vídeo Selfie com o gato, de 
duas formas: por meio de uma retextualização e/ou da criação de uma nova história com um texto multimodal, por exemplo.

Após a exibição do curta, deve-se investigar as dificuldades apresentadas pelos participantes ao que se refere à leitura desse texto multimodal. Em seguida, propor a retextualização do texto multimodal, por meio da modalidade verbal escrita, ou seja, solicitando que o aluno relate o enredo do vídeo com detalhes.

$\mathrm{Na}$ etapa seguinte, para aprimorar a leitura desse gênero, é pertinente realizar atividades que tenham como objetivo conduzir o aluno a uma leitura mais reflexiva da linguagem do curta, isto é, da linguagem cinematografia e dos elementos para a realização do vídeo - com perguntas sobre planos, ângulos e movimentos de câmera, os tipos de linguagem, som -, com o intuito de trabalhar o texto multimodal.

Para isso, nas próprias atividades, os termos do universo da linguagem cinematográfica devem ser explicados, bem como sobre os elementos da narrativa. Nessas atividades, questões de compreensão da narrativa, por exemplo, personagens, espaço, tempo, ações, desfecho também são importantes.

Após a realização das atividades e discussões realizadas a partir da sua execução, deve-se solicitar que o aluno acrescente ao seu texto (relato) novas informações, coletadas das atividades feitas. Esta aplicação tem por finalidade verificar se a leitura inicial realizada pelos alunos foi modificada e ampliada com a inclusão de novos elementos, depois das atividades e discussões realizadas.

Uma das funções mais árduas dos professores de português é conduzir o aluno a reescrever seu texto ou 
aprimorá-lo. Os alunos ainda não veem a importância dessa ação e muitos professores terminam cedendo e não realizam esta prática, quebrando assim uma etapa importante do processo de aprendizagem da escrita.

O vídeo é um texto com elementos que precisam ser estudados na sala de aula. Segundo Silva (2014b, p. 136137), "quando lidamos com as chamadas linguagens complexas, devemos considerar as relações entre os códigos verbais, visuais e sonoros para a composição da mensagem que se deseja transmitir". Logo, concordamos que "a alfabetização dos espectadores na gramática cinematográfica é o melhor caminho para constituir um público menos passivo e mais exigente" (COSTA, 2013, p. 105).

\section{Criando textos multimodais}

Para dar continuidade ao estudo, apresentamos como sugestão a produção de textos multimodais, partindo-se de um enredo. Assim, amplia-se a concepção escolar de texto e de leitura, propiciando aos alunos a construção do sentido de um texto multimodal, testando a criatividade narrativa dos alunos e as habilidades com os recursos para contar uma história por meio de imagens ou palavras e imagens, construindo uma rede intertextual que se apoia na prática da leitura e da escrita.

Isto tudo após a exposição sobre o que é um enredo, sobre a necessidade de se fazer um relato sobre os fatos vividos pelas personagens e ordená-los em uma sequência lógica e temporal; usando de alguns elementos linguísticos, como por exemplo, o uso de verbos de ação que indicam a movimentação das personagens no tempo e no espaço. Geralmente, o enredo está centrado num conflito, 
que responsável pelo nível de tensão da narrativa. E, depois, em um outro momento, criar um storyboard, a partir das indicações sugeridas no vídeo Como criar storyboard (CARVALHO, 2016), buscando levar o aluno a entender o processo de criação das cenas ou, simplesmente, dos quadros que ganham vida, quando se agregam outras linguagens, movimentos e som, cor e efeitos.

Pode-se iniciar esta etapa de produção textual distribuindo notícias/acontecimentos sobre selfie, divulgados na internet, dando continuidade ao assunto do curta Selfie Cat, para que os alunos produzam um enredo e, logo, em seguida um storyboard com a seguinte temática "Consequências de selfies", realizando, assim, o gênero multimodal, que pode ainda ser transformado em um curta, caso haja recursos.

Embora tenhamos sintetizado várias etapas importantíssimas na produção de um audiovisual, como por exemplo, o roteiro, o qual não trabalhamos, esta proposta pode levar a uma compreensão da linguagem de um vídeo, da sua realização e produção.

\section{Considerações finais}

Nessa proposta de estudo, partimos de uma prática corriqueira que é assistir a vídeos curtos. Esta atividade é habitual, se considerarmos a frequência com que as crianças e adolescentes assistem a vídeos; entretanto, mostra-se complexa quando se intensifica a necessidade de ler tais textos e não simplesmente vê-los. E, mais ainda, quando se impõe a necessidade de produção textos multimodais.

Os pontos positivos quando à leitura, na execução dessa proposta de curtas-metragens, é levar o aluno não 
só a ver um vídeo, mas também a entender a linguagem usada pelo texto multimodal, pois como lembra Silva (2014a), todos os recursos utilizados e colaborados para o enriquecimento da mensagem que se deseja passar.

Destacamos que os professores não precisam ser profissionais da área cinematográfica, mas alguém que acredita no potencial dos curtas-metragens e têm interesse em conhecer mais sobre esse texto multimodal, para poder melhor utilizá-lo em sala de aula.

Por fim, acreditamos no poder comunicativo, interativo e incentivador do curta; e, em professores engajados e capazes de conduzir os alunos a saberem atribuir sentidos a mensagens com múltiplas formas de linguagens, bem como a produzirem textos multimodais.

\section{Referências}

ALCÂNTARA, Jean C. D. Curta-metragem: gênero discursivo propiciador de práticas multiletradas. 138 p. Dissertação (Mestrado em Estudos de Linguagem) Instituto de Linguagens, Universidade Federal de Mato Grosso, Cuiabá-MT, 2014.

ARENAANIMATION. Twisted. YouTube, 13 dez. 2017. Disponível em: <https://www.youtube.com/watch?v=J_daotPZ2Kk>. Acesso em: 10 jun. 2017.

ARTFX. Selfie Cat. YouTube, 6 jul. 2016. Disponível em: <https://www.youtube.com/watch?v=LEL81DVIHMk>. Acesso em: 15 mar. 2017. 
AUMONT, Jacques; MARIE, Michel. Dicionário teórico e crítico de cinema. Trad. Eloisa Araújo Ribeiro. 5. ed. $3^{\text {a }}$ reimpressão. Campinas, São Paulo: Papirus, 2015.

BERNARDET, Jean-Claude. O que é cinema. $14^{\mathrm{a}}$ reimpressão. São Paulo: Brasiliense, 2004. (Coleção Primeiros Passos; 9)

BRASIL. Ministério da Educação. Base Nacional Comum Curricular. MEC. Brasília, DF, 2017.

. Secretaria de Educação Fundamental. Parâmetros curriculares nacionais: terceiro e quarto ciclos do ensino fundamental: introdução aos parâmetros curriculares nacionais. Brasília: MEC/SEF, 1998a. 174 p.

. Secretaria de Educação Fundamental. Parâmetros curriculares nacionais: terceiro e quarto ciclos do ensino fundamental: língua portuguesa. Brasília: MEC/SEF, 1998b. 106 p.

CARVALHO, Vitor. Como criar storyboard. YouTube, 5 ago. 2016. Disponível em: <https://www.youtube.com/ watch?v=RZcuGbbWNaQ>. Acesso em: 17 nov. 2017.

COSTA, Cristina. Educação, imagem e mídias. 2. ed. São Paulo: Cortez, 2013. (Coleção aprender e ensinar com textos, v. 12/ coord. geral Ligia Chiappini)

DIONISIO, Angela P. Gêneros textuais e multimodalidade. In: KARWOSKI, Acir Mário; GAYDECZKA, Beatriz; BRITO, Karim S. (Orgs.). Gêneros textuais: reflexões e ensino. 4. ed. São Paulo: Parábola, 2011. 
GANCHO, Cândida V. Como analisar narrativas. 9 ed., $8^{\text {a }}$ impressão. São Paulo: Ática, 2014. (Princípios; 207)

HOUAISS, A.; VILLAR, M. S. Dicionário Houaiss de Língua Portuguesa. Elaborado pelo Instituto Antônio Houaiss de Lexicografia e Banco de Dados da Língua Portuguesa S/C Ltda. Rio de Janeiro: Objetiva, 2009.

INDURSKY, Freda; ZINN, Maria Alice K. Leitura como suporte para a produção textual. In: Leitura: teoria \& prática. $\mathrm{n}^{\circ}$ 05, Campinas-SP: Mercado Aberto/ABL, 1985. p. 22-36.

$\mathrm{KOCH}$, Ingedore V.; ELIAS, Vanda M. Ler e compreender: os sentidos do texto. 3. ed., $11^{a}$ impressão. São Paulo: Contexto, 2015.

MASETTO, Marcos T. Mediação pedagógica e o uso da tecnologia. In: MORAN, José M.; MASETTO, Marcos T.; BEHRENS, Marilda A. (Orgs.). Novas tecnologias e mediação pedagógica. 9 ed. Campinas, SP: Papirus, 2005.

MESQUITA, Samira N. O enredo. 4. ed., $8^{a}$ impressão. São Paulo: Ática, 2006. (Princípios; 36)

MOLETTA, Alex. Criação de curta-metragem em vídeo digital: uma proposta para produções de baixo custo. 3 . ed. São Paulo: Summus, 2009.

MORAN, José M.; Ensino e aprendizagem inovadores com tecnologias audiovisuais e telemáticas. In: MORAN, José M.; MASETTO, Marcos T.; BEHRENS, Marilda A. Novas tecnologias e mediação pedagógica. 9. ed. Campinas, SP: Papirus, 2005. p. 11-65. (Coleção Papirus Educação) 
. O vídeo na sala de aula. In: Comunicação \&

Educação. São Paulo, ECA-Ed. Moderna, [2]: 27 a 35, jan./ abr. de 1995.

NAPOLITANO, Marcos. Como usar o cinema na sala de aula. 5. ed., $2^{\mathrm{a}}$ reimp. São Paulo: Contexto, 2015.

RIBEIRO, Carla.G. O curta-metragem como recurso didático para aula de E/LE. 2013. 146 p. Dissertação (Mestrado em Linguagem) - Faculdade de Letras, Universidade de Coimbra, Coimbra.

RIBEIRO, Ana E. Textos multimodais: leitura e produção. Paulo: Parábola, 2016. (Linguagens e tecnologias; 4)

ROJO, Roxane H. R. Pedagogia dos multiletramentos: diversidade cultural e de linguagem na escola. In:

MOURA, Eduardo. (Orgs.). Multiletramentos na escola. São Paulo: Parábola, 2012. p. 11-31. (Estratégias de ensino; 29)

.; BARBOSA, Jacqueline P. Hipermodernidade, multiletramentos e gêneros discursivos. São Paulo: Parábola, 2015. (Estratégias de ensino; 51)

SILVA, Salete T. A. A linguagem cinematográfica na escola: uma leitura d'O Rei Leão. In: CITELLI, Adilson (Coord.). Outras linguagens na escola: publicidade, cinema e TV, rádio, jogos, informática. 5. ed. São Paulo: Cortez, 2014a. (Coleção aprender e ensinar com textos, v. 6) p. 89-120.

_. Desenho animado e educação. In: CITELLI, Adilson (Coord.). Outras linguagens na escola: publicidade, 
cinema e TV, rádio, jogos, informática. 5. ed. São Paulo: Cortez, 2014b. (Coleção aprender e ensinar com textos, v. 6) p. 121-147.

SOLÉ, Isabel. Estratégias de leitura. Trad. Claudia Schilling. 6. ed. $1^{\text {a }}$ reimpressão. Porto Alegre: Penso, 2012.

VANOYE, Francis; GOLIOT-LÉTÉ, Anne. Ensaio sobre a análise fílmica. Trad. Marina Appenzeller. 7. ed., $3^{\mathrm{a}}$ reimpressão. Campinas, SP: Papirus, 2014. 


\title{
HIPERTEXTO: \\ a força propulsora para o ensino de leitura e escrita na aula de Língua Portuguesa
}

\author{
Anahy Zamblano ${ }^{1}$
}

\section{Introdução}

Faz-se notória a popularização das tecnologias de informação e da comunicação em todos os âmbitos sociais. Essa popularização tem levado o cidadão a aprender novas formas de lidar com a informação, logo, tem reaprendido a ler e a escrever. Surge, então, uma forma de ler revolucionária e uma escrita econômica (XAVIER, 2005:171) que se tem apresentado para a sociedade juntamente com essas novas tecnologias. É nesse universo tecnológico em que novos e velhos modos enunciativos se entrecruzam, deixando curiosa e inquieta toda uma comunidade

1 Doutora em Estudos da Linguagem pela Universidade Federal do Rio Grande do Norte (UFRN). Mestre e Graduada em Letras pela Universidade Federal da Paraíba (UFPB). Professor Adjunto da Universidade de Pernambuco. Docente permanente do Programa de Pós-Graduação em Letras da UPE (PPGL-UPE Mata Norte) e do Mestrado Profissional em Letras (PROFLETRAS). Coordenadora do Laboratório de Leitura e Textualidade (LALT/ UPE). Coordenadora do PIBID/UPE/Português. Membro do Grupo de Pesquisa Análise Textual dos Discursos (UFRN), do GEDIM (UFES), CELLUPE (UPE), e do Grupo de Pesquisas Interdisciplinares em Formação de Professores, Política e Gestão Educacional UPE. E-mail: anahyzamblano@upe.br 
de profissionais que trabalham com a linguagem e com a educação, entre outros setores. Apesar da chegada dessas novas formas de ler, temos simultaneamente um conjunto de leitores que são considerados, pelos indicadores de qualidade educacional (PISA, ENEM, SAEB), pouco eficientes na forma de compreender e interpretar textos. Com suas raras exceções, esses indicadores nos mostram o quão precário está o trabalho com as formas de ensino da leitura proficiente e da produção de textos eficazes no Brasil. Esse sofrível desempenho tem sido consequência de um ensino de língua materna totalmente desvinculada das reais necessidades de uso social da linguagem por parte do aluno. E, portanto, não se pode permitir que esse aluno continue sem saber apreender, apropriar-se, e transformar significados a partir de um documento escrito (SILVA, 2003) ou (acréscimo nosso) hiperescrito. Dessa forma, é preciso priorizar nas aulas de língua portuguesa, as atividades de leitura e produção de texto, dentro de uma concepção de língua que possa vir a contribuir significativamente para o desenvolvimento das competências do ato de ler e escrever. E por que não utilizar o letramento digital para isso? O que pode ser feito para minimizar essa difícil situação de leitura superficial?

\section{A aula de língua portuguesa}

Desde o ensino fundamental tem-se uma aula voltada totalmente para a valorização da língua enquanto código supremo, enquanto estrutura. A persistência de um ensino classificador e nomeador ainda impera nas práticas pedagógicas da aula de língua portuguesa. Essa forma estrita de se ensinar o português, acaba por promover 
uma amputação natural do trabalho com a língua em suas várias nuanças. Advém desse quadro, portanto, um eterno insucesso escolar. Com enormes dificuldades, o aluno cria um repúdio inconsciente a todas as formas de ler e escrever academicamente, e isso tem abalado as mais diversas estruturas do saber.

É válido salientar que mesmo cientes da reorientação curricular, problemas graves ainda persistem no sistema público de ensino brasileiro. A escola em pleno séc. XXI tem sérias dificuldades em ensinar o aluno a ler e a escrever. O problema de o aluno não conseguir ler e simultaneamente compreender e interpretar bem o texto escrito está no fato de que existe uma falha na proposta de se encarar o objeto de ensino de língua na sala de aula. Faz-se necessário um trabalho que redimensione o objeto de ensino da língua portuguesa. É preciso sair do marasmo das aulas de classificar as palavras desvinculadas de um texto e tampouco é correto usar o texto como pretexto, como tem sido feito em muitas salas. Urge a necessidade de se trabalhar outras dimensões além da gramática 'pura' . É preciso, então, trabalhar a oralidade, a escrita - sem ignorar a interferência do sujeito -, a leitura - sem encará-la como o soletrar em voz alta de enunciados -, e a gramática - não como algo estagnado e friamente isolada do contexto em que se encontra. Assim sendo, a língua não é estrutura (algo fixo) e sim estruturação, parte de um trabalho de interpretação, através do qual se observa como o sujeito estrutura sua língua, vendo o movimento de sentidos e permitindo que este sujeito seja capaz de perceber e compreender esses sentidos. A problemática maior consiste em como reverter esse panorama estafado em que nossa comunidade estudantil se encontra? Como sugerir momentos instigantes 
para que os agucem a procurar enxergar a outra parte do texto que se camufla nas entrelinhas da interpretação? Como tranquilizá-los sobre o ato de escrever? Como mostrá-los que a essência da escrita e da leitura já existe em cada um deles. Certamente, um apontar novo será preciso para iniciá-los outra vez em uma estrada que (eles) estão há algum tempo caminhando, mas que não conseguem sair do círculo da mesmice e visualizar um horizonte promissor de escritores e leitores proficientes.

\section{A interferência do aluno-sujeito- (hiper)leitor}

Torna-se, humanamente, impossível falarmos em leitura e em escrita, sem falarmos em sujeito, uma vez que é esse aluno-sujeito que é o leitor/ escritor ou hiperleitor/ hiperescritor. A leitura, sem margem de erro, é hoje um pilar sem sustentação e, por assim dizer, tem abalado o nível do conhecimento na sua acepção mais abrangente que o termo permita existir. A escola como principal geradora do conhecimento tem-se mostrado aflita e várias práticas e inovações têm acontecido, mas infelizmente não tem minimizado o problema. As aulas têm sido dadas, orientações de se trabalhar o texto têm sido respeitadas, mas nada parece melhorar a capacidade leitora e, por conseguinte, escritora dos nossos alunos e isso tem despertado em estudiosos da linguagem e da educação uma grande ânsia em ajudar nossa comunidade, nossa cidade, nosso estado e nosso País a romper essa barreira que os estudos ${ }^{2}$ nos apresentam.

2 PISA (2000) 
O aluno não consegue sair do marasmo da leitura presa nas linhas do texto, não conseguem manusear os vários sentidos que o perpassam a fim de decidir-se pelo sentido mais coerente advindo das inferências do texto.

De acordo com Possenti (1990:59), “a questão do sujeito é uma das questões fundamentais na análise do discurso" e, para nós, é, portanto, uma das maneiras de se entrar na questão central desse trabalho, que é apropriar o sujeito/aluno/internauta da competência leitora e escritora com eficiência. Para tanto, faz-se necessário entendermos a concepção de sujeito para a Análise do Discurso, uma vez que, a nosso ver, é quem melhor nos esclarece tal concepção.

É a partir da relação entre discursos que obtemos os recortes de sentidos que vão se configurando entre si, resultando nos contornos de textualidade. São esses recortes que nossos alunos não conseguem na maioria das vezes compreender/ interpretar. Esses sentidos pertencem ao domínio de memória dos diversos discursos que se cruzam no evento. Por exemplo, "Droga se fosse bom não teria esse nome. Não use droga." retirado de uma campanha contra as drogas, cruzam-se nesse discurso vários outros discursos, os quais podemos caracterizá-los como discurso lexicográfico que está presente quando se fala no nome droga (portanto, cientifico) e discurso moral que está presente quando produz o efeito de que não se deve usar droga. É a partir desse cruzamento que se obtém o efeito negativo da droga. O efeito é o de um discurso legítimo, digno de respeito, uma vez que é embasado cientificamente (Guimarães, 1995). Não esquecendo que todo 
sujeito trabalha numa relação entre o intradiscurso ${ }^{3} \mathrm{e} o$ interdiscurso ${ }^{4}$, podemos afirmar que esse é, em nível de interdiscurso, sempre afetado por sentidos do mundo interpretado. Afetado pelo interdiscurso, o sujeito-aluno faz uma seleção a fim de construir seu intradiscurso, buscando, acima de tudo, preservar a unidade, a coesão de seu discurso configurado como texto. $\mathrm{O}$ que temos percebido é que nossa prática em sala de aula de língua portuguesa não tem promovido exercícios que trabalhem mais freqüentemente esse manuseio necessário entre o inter e o intradiscurso do aluno. Essa prática rotineira, ou seja, exercícios que buscassem mais os recortes de textualidade ou exercícios que 'puxassem' mais pelos implícitos e subentendidos poriam em prática um lado não trabalhado em sala de aula, o lado da interpretação. Em outras palavras, o lado do despertar do raciocínio perspicaz. Concebemos o "Discurso", segundo a Análise do Discurso, "como acontecimento histórico-social, isto é, um acontecimento permeado por influências sociais que o condicionam e atravessado por " $\mathrm{n}$ " discursos com os quais dialoga." (Cardoso, 1994)

Em função disso, o sujeito-aluno mantém uma relação, com o mundo, que é afetada pelo sentido que a forma linguística nos fornece. Frequentemente, quando falamos,

3 É o que dá coerência ao propósito do sujeito. (Pêcheuax, 1995)

4 "O interdiscurso consiste em um processo de reconfiguração incessante no qual uma formação discursiva é levada (...) a incorporar elementos pré-construídos, produzidos fora dela, suscitando, o chamamento de seus próprios elementos para organizar sua repetição, mas também provocando, o esquecimento ou mesmo a denegação de determinados elementos" (Maingueneau, 1997: 113) 
temos a sensação de que atingimos o mundo, mas, na verdade, temos apenas uma visão que acreditamos que é universal. Isto é, acreditamos que a "nossa" imagem é um caminho em direção ao universal. Cientes de que existe uma multiplicidade de sentidos (interpretações), nos centralizamos em apenas uma única interpretação, pois caso isso não aconteça, teremos dificuldade em produzir unidade textual. É preciso salientar que o sujeito não tem acesso a todos os sentidos das formas linguísticas, isso ocorre porque temos apenas uma visão da realidade objetiva; sendo mais claros, tomamos a parte pelo todo. Quando o sujeito lança mão de sua visão primeira, ele tem a impressão de que todo mundo tem conhecimento dela, o que não é verdade, pois cada sujeito se identifica com um universo diferente de sentidos, possuindo visões distintas para um mesmo objeto. O problema está no fato, segundo o PISA (2000), de que o aluno-sujeito não está sabendo "sacar" esses sentidos e chegar, portanto, as informações implícitas que todo texto oferece. Talvez, o suporte escrito oferecido como material de aula nas escolas não tem chamado tanta atenção do sujeito-aluno e esse parece sempre desinteressado nas leituras solicitadas em sala de aula. Eles lêem livros, resumos e quando são inquiridos sobre o que leram não conseguem sair do nível mais elementar da leitura que é a compreensão, ou seja, o nível em que se percebem estruturas grandes que passeiam aos nossos olhos no texto, como espaço, personagens, tempo, etc. Quando questionados sobre uma análise mais acurada do que leram não conseguem responder com precisão e sempre mostram um desinteresse por leitura e por produção textual também. 
Sem dúvida nenhuma, as diferenças sociais marcam o discurso da rejeição para com a leitura e com a escrita, isto é, o fato de a sociedade ser heterogênea é suficiente para que os sujeitos não tenham a mesma imagem das coisas. Cada sujeito possui uma determinada formação discursiva e esta é definida a partir do interdiscurso do sujeito. Em outras palavras, a formação discursiva de um sujeito é determinada pela posição social que ele ocupa. Segundo Maingueneau (1997:113), “a formação discursiva aparece como o lugar de um trabalho no interdiscurso; ela é um domínio "inconsistente", aberto e instável, e não a projeção, a expressão estabilizada da "visão do mundo" de um grupo social". O conceito de formação discursiva, também chamada de imaginária, nos é importante na medida em que permeia os processos discursivos do sujeitor-aluno, uma vez que estes processos se constituem numa série de formações imaginárias que designam o lugar que eles estão e o lugar que gostariam de estarem, a imagem que eles se fazem de seu próprio lugar e do lugar do outro e a imagem do texto, caracterizando assim o que Althusser define como interpelação do indivíduo em sujeito pela sociedade (ideologia, família, religião política, etc) ${ }^{5}$.

Até agora falamos da relação imbricada entre sujeito, discurso e língua. Essa relação só se faz imbricada por causa do sentido que os envolve. Antes de determinarmos a nossa concepção de sujeito, que, diga-se de passagem, é encontrada em Authier-Revuz, faremos uma

5 O que digo aqui foi a partir de observações feitas pelo Prof. Dr. Aloísio de Medeiros Dantas durante o mini-curso "Introdução à Análise de Discurso" oferecido pelo Departamento de Letras (UFPB-Campus II), 1999. 
"refrescagem" de memória sobre as três noções de sujeito. A primeira é a noção subjetivista ingênua, a qual nos diz que o sentido nasce da intenção do sujeito - NOÇÃO IDEALISTA advinda de Benveniste. A segunda diz respeito à noção clássica da Análise do Discurso na década de 70 - NOÇÃO IDEOLÓGICA advinda de Pêcheux:

“Todo indivíduo humano, isto é, social, só pode ser agente de uma prática se se revestir da forma de sujeito. A "forma-sujeito", de fato, é a forma de existência histórica de qualquer indivíduo, agente das práticas sociais." (Pêcheux, 1997)

A terceira, e seguida por nós, é a noção que busca uma nova concepção de sujeito. Para tanto, Authier-Revuz lança mão de duas idéias:

a) dialogismo de Bakhtin [o sujeito é parcialmente consciente (grifo nosso)]

“Toda palavra serve de expressão a um em relação ao outro. Através da palavra, defino-me em relação ao outro, isto é, em última análise, em relação à coletividade".

(Bakhtin, M. Marxismo e Filosofia da Linguagem. São Paulo: Hucitec, 1990:113) 
“Nenhuma palavra é 'neutra', mas inevitavelmente 'carregada', 'ocupada', 'habitada', 'atravessada' pelos discursos nos quais 'viveu sua existência socialmente sustentada'".

(Authier-Revuz,J. Heterogeneidade(s) Enunciativa(s). In: Cadernos de Estudos Lingüísticos 19. Campinas: UNICAMP, p.27)

b) A teoria do inconsciente [teoria atravessada pelo outro, não o outro social, mas o outro inconsciente (grifo nosso)]

"A fala é fundamentalmente heterogênea e de um sujeito dividido. (...) Sempre sob as palavras, "outras palavras" são ditas: é a estrutura material da língua que permite que, na linearidade de uma cadeia, se faça escutar a polifonia não intencional de todo discurso, através da qual a análise pode tentar recuperar os indícios da "pontuação do inconsciente" (Authier, J. "Heterogeneidade(s) Enunciativa (s)". Cadernos de Estudos Lingüísticos 19. Campinas: UNICAMP, p.27)

É a concepção de um sujeito clivado que vamos encontrar nas salas de aulas de língua portuguesa. É preciso observar que tudo aquilo dito pelo sujeito clivado só tem sentido no espaço e no jogo em que ele se envolve com o outro na interação real ou por que não dizermos 
virtual, também. Voltando ao postulado geral da $\mathrm{AD}$, FALAR É SIGNIFICAR e só significa a partir desse jogo e do espaço constitutivo do sujeito e do outro. Estaremos interessados no sujeito do discurso, que é uma posição, e não no sujeito da enunciação, que é uma referência. (Gallo, 1994: 49). Estamos preocupados em compreender esse sujeito das nossas salas de aula e como ajudá-lo a galgar patamares outros que tragam uma melhoria significativa no desempenho de ser leitor e escritor eficaz.

Como ficou exposto, temos diante de nós alunos que são, na verdade, sujeitos clivados de " $n$ " sentidos e que não sabem manuseá-los, nem preferir um sentido a outro quando o assunto é interpretar, simplesmente por que não estão habituados a responderem exercícios que vão além das linhas, isto é, da intelecção. Se não são colocadas situações que os façam produzir, preferir, desprezar, argumentar, inferir sentidos não vão desvendar a parte implícita de um texto quando assim for preciso. Por isso, nossa pesquisa fadada de presenciar essa 'amputação' de produção de leitura e escrita, resolve 'lançar mão' da tecnologia e sendo mais específicos do suporte digital, com veemência na ferramenta "weblog" a fim de promover uma prática diferente. Vamos aproveitar o que mais se faz na internet que é ler a favor do ensino-aprendizagem da leitura e escrita proficiente.

\section{O weblog: uma prática inovadora para encantar o aluno}

Antes de nos debruçarmos no hipertexto e nas suas contribuições para o estudo da língua, faz-se necessário desenharmos como surgiu a internet. Segundo Turkle (1995), a grande contribuição da computação não é mais 
no âmbito das possibilidades de cálculo, mas da possibilidade de simulação. Assim, os chats seriam simulações de conversas naturais, enquanto os e-mails seriam as cartas modernas que muitas vezes elaboramos mentalmente e nunca derramamos no papel e os weblogs a nova versão de um diário que não é mais particular como antes. Parece mais simples teclar do que escrever linhas e linhas. A modernidade $^{6}$ vem desbancando certos mitos, como o de escrever obedecendo às regras da gramática normativa, a qual diz que não se inicia frases com pronome oblíquo. Sem dúvida, é o que mais encontramos nos canais abertos de chats whatsApp e até mesmo de e-mails (trocados entre amigos). Parece-nos que o importante é que haja comunicação, e os internautas não estão preocupados com o rigor de se escrever linhas para alguém seguindo as normas da Gramática Normativa e conservando assim a imagem ${ }^{7}$ de língua que aprenderam nas escolas.

Nas linhas que seguem, faremos uma retrospectiva de como surgiu e como acontecem as interações mediadas por computador, a fim de compreendermos melhor a pesquisa. Parafraseando Vellasco (1999), foi o Projeto da Advanced Research Projects Agency (Arpa), do Departamento de Defesa dos Estados Unidos da América,

6 De acordo com Sérgio Paulo Rouanet e José Guilherme Merquior (In.: PROENÇA FILHO, Domício. Pós- Modernismo e Literatura. Ed. ática, 1995: 11-12) ainda estamos vivendo na modernidade. Nos termos dos autores, "período que ocorre uma ruptura radical caracterizadora de algo realmente diferenciador".

7 Imagem refere-se ao conceito de Formação Imaginária (o modo como os interlocutores vêem a si e aos outros numa interação verbal), formulado por Pêcheux. 
para permitir a partilha de recursos computacionais entre os pesquisadores, que deu origem à Internet em 1969. Por volta de 1980, essa rede foi dividida em duas outras: a Arpanet e a Milnet. A primeira se dedicava a desenvolver pesquisas civis com fins militares e a segunda exclusiva dos usos militares. Pouco tempo depois, a junção das duas redes passa a ser chamada de Defense Advanced Research Projects Agency Internetwork, popularmente conhecida como Internet. Lançada oficialmente em 1990, sob a coordenação política e orçamentária do Conselho Nacional de Desenvolvimento Científico e Tecnológico (CNPq), a Internet tomou proporções gigantescas a partir de 1995, quando logrou efetiva consolidação não só no meio acadêmico - Instituições - com também nas residências, atingindo um público em 1998, segundo o resultado da pesquisa anual do "cadê?" (Guerra Vicente, 2000), superior a 1 milhão de brasileiros conectados. Em 2007, esse número aumentou consideravelmente para 30 milhões de brasileiros.

Quando se fala em comunicação mediada por computador, doravante de CMS, vê-se logo que os valores aos poucos foram se modificando, houve fragmentação do indivíduo e o que antes parecia ser impossível, hoje já não o é mais. Quem ousou pensar, em frações de segundos, se comunicar com um parente do outro lado do mundo? Quem poderia receber livros ou CD's, sem nem ao menos tocar no telefone ou sair de casa? Pois é, algum tempo atrás essas coisas não passavam de ilusórias e por que não dizer absurdas? Hoje, isso e muito mais já acontece e tudo graças à inteligência do homem que criou essa máquina esquisita e que ainda causa estranhamento em alguns, o computador. Aliado a ele (o computador), a rede de 
comunicação - Internet - é responsável por todas essas façanhas. A rede virtual nos dá a sensação de vivermos num mundo de distâncias mais curtas, o que traz uma confortável posição diante dessa globalização que nos engole. Mas, indagamo-nos, o que é o virtual? Segundo Lévy (1996:12), o virtual é "um processo de transformação de um modo de ser num outro". Assim, as comunicações mediadas por computadores acontecem virtualmente marcadas por características reais, como a massificação do diálogo, a materialização através de símbolos, das expressões faciais, como o sorriso ou o choro. Não há limites em se tentar suprir a falta do outro ao seu lado como se estivessem num bate-papo real. A interação ora entre dois sujeitos, ora entre vários se configura como um transporte de mensagens que contribui para modificar ou estabilizar significações cristalizadas de uma sociedade.

Heterogênea e complexa por natureza, a linguagem sempre despertou a atenção dos estudiosos e a exemplo desses, nossa atenção também foi despertada a fim de entendermos, em particular, o funcionamento dela (a linguagem) no meio cibernético e como podemos nos utilizar desse meio para reverter nosso quadro de insucesso escolar no que diz respeito à leitura e à escrita. Esse meio de realidade virtual que se comporta e é aceita como realidade natural tem hoje para a educação um papel de importância grandiosa, uma vez que apoiados nesse mundo cibernético e especificamente nos hipertextos ${ }^{8}$ podemos trazer o aluno para uma realidade que ele por " $n$ " moti-

8 “Tecnologia enunciativa híbrida e flexível que dialoga com outras interfaces midiáticas e acondiciona formas outras de textualidade". (XAVIER, 2005) 
vos rejeita, a realidade de se propor a ler e a escrever com desenvoltura. Ocupando uma das últimas posições no PISA - Programa Internacional de Avaliação - o Brasil apresenta um péssimo nível de leitura e, por conseguinte, de escrita. Acreditamos que, sem notar, o que mais se faz na Internet é ler e, então, por que não se aproveitar essa veia e tentar redesenhar nosso nível de leitura e escrita para um futuro melhor.

Visto como uma tecnologia enunciativa que mistura imagens, sons, gráficos, vídeos e textos, o hipertexto atraiu indiscutivelmente a todos que tenham tido um dia acesso a ele e acaba, assim, contribuindo para a formação de aprendizes críticos e criativos. A leitura nesse suporte se comporta de forma inusitada, é dotada de uma deslinearidade e isso promove uma atenção desdobrada para o aprendiz, possibilitando-lhe o criar de seus caminhos e alimentando certa autonomia para filtrar o que quer ou não ler. Assim sendo, estudiosos como, Xavier (2005) nos mostra que a utilização frequente do hipertexto gera no usuário características como:

- Independência eautonomia na aprendizagem

- Abertura emocional e intelectual

- Fluência verbal (escrevem/lêem mais)

- Curiosidade e faro investigativo

- Raciocínio rápido e sistemático

- Senso de imaginação

- Competência argumentativa na defesa idéias. 
Essas características mostram, portanto, que a utilização do hipertexto no meio educacional é algo interessante e pode trazer bons frutos para o ensino e aprendizagem do ato de ler e escrever. Portanto, a internet, ou melhor, o hipertexto pode nos dar um respaldo para desenvolver uma prática pedagógica de estudo e exploração da escrita e da leitura, cabendo ao professor reconstrutor a criar subsídios de fazer acoplar a isso tudo, a oralidade e a gramática.

\section{O ‘Trampolim' para o ato de ler e escrever}

Já houve o período em que se adotava a concepção de letramento enquanto conhecimento estrito do código, ou seja, visto apenas como forma de aquisição da escrita, ligada unicamente ao âmbito da escola que é, de acordo com Kleiman (1995:20), a agência oficial de letramento. Essa ideia foi ultrapassada por novas formas de letramento e se compreende, hoje, letramento sendo uma prática social que se processa segundo especificidades requeridas pelos contextos onde se efetiva a comunicação linguística por meio da escrita (LOPES, 2006: 36). A modernidade trouxe, então, o letramento digital. Este, às vezes, tem sido mais presente do que o próprio letramento alfabético. Crianças que ainda titubeiam nas letras, já sabem correr os hipertextos e os gêneros digitais advindos dele. É através do letramento digital que chegamos ao hipertexto e este metaforizado como a ponta do iceberg das inovações tecnológicas, linguageiras e sociais tem sido uma promessa promissora à leitura e à escrita há algum tempo.

Precisamos de uma força propulsora para nos retirar da calamitosa situação em que estamos imersos. Na 
verdade, precisamos de um 'trampolin' para nos fazer mudar de plano, significativamente. A nosso ver, esse trampolim é o letramento digital ${ }^{9}$, uma vez que esse tipo específico de letramento permite velocidade no ato de captar, aprender e compartilhar conhecimento e amplia o dimensionamento perceptual ${ }^{10} \mathrm{dos}$ dados apresentados no hipertexto.

Errôneas são as opiniões dos que acreditam que a utilização das ferramentas digitais (e-mails, chat's, blogs) pode macular a escrita da língua portuguesa. Estudos afirmam que isso não é possível, já que por mais ou menos letrado que o indivíduo possa vir a ser, ele tem uma noção do que é adequação linguística. Em outras palavras, a maioria dos usuários da língua sabe que não se escreve da mesma forma em todos os gêneros e suportes de escrita. Portanto, essa ideia de macular a língua por se economizar letras ou suprimir palavras não faz sentido.

Não há dúvida de que o que mais se faz na internet é ler, o que se questiona é sobre a qualidade dessa leitura. E, é claro, quando se lê se cria textos. Uma atividade está imbricada na outra e não podem ser desassociadas. Não se pode desprezar essa teia, ou melhor, essa rede. Ela pode auxiliar e muito a educação de nossos jovens. Cabe ao educador, criar formas outras de se levar para o contato do aluno na sala de aula o trabalho com hipertextos.

9 um certo estado ou condição - do letramento - que adquirem os que se apropriam da tecnologia digital e exercem praticas de leitura e de escrita na tela, diferente do estado ou condição - do letramento - dos que exercem práticas de leitura e de escrita no papel (Soares, 2002, p. 151).

10 Verbal-visual - auditivo. 
Foi pensando assim, que implantamos (2006), na Universidade de Pernambuco, hoje Campus Mata Norte, na categoria de um projeto de extensão, uma nova forma de se trabalhar leitura e produção de textos. A turma pioneira foi composta por 45 alunos, dos cursos de licenciatura em Letras, Matemática, Biologia, Geografia e Pedagogia e o resultado satisfatório se estende até os dias de hoje. Já estamos na 12a . Edição do curso e temos apenas uma turma por ano. Em 2018, o curso de extensão intitulado "Ler, escrever e digitar" ministrado no Laboratório de Leitura e Textualidade teve inscritos 40 alunos que eram participantes do Programa Institucional de Bolsa a Docência - Pibid. As aulas foram divididas em duas categorias: aulas presenciais e não presenciais. As não presenciais aconteceram por meio de e-mails e através da elaboração de um blog criado com o fim educativo. Os alunos demonstraram no início do curso que se desenvolveu no LALT ${ }^{11}$, sérias dificuldades para atingirem leituras interpretativas e produzirem textos desenvoltos. Eram sujeitos clivados por " $n$ " sentidos e não conseguiram um equilibro inicial entre o inter e o intradiscurso. O maior intuito do LALT desde sua criação era fazer com que os alunos escrevessem sem 'receio' e lessem sem 'pavor' ${ }^{12}$. Esse intuito tem sido paulatinamente alcançado com o auxílio do letramento digital, especificamente através do $\mathrm{BLOG}^{13}$ que visa disponibilizar caminhos ao professor de língua materna para uma prática de leitura mais eficaz e

11 Laboratório de Leitura e Textualidade, sob a coordenação da Profa. Dra. Anahy Zamblano.

12 Grifo nosso.

13 O blog constitui-se um gênero emergente no contexto digital. De acordo com Komesu (2005), o termo vem de weblog, ou 
efetiva, utilizando a tecnologia a favor da aprendizagem. $\mathrm{O}$ uso do blog possibilitou o desenvolvimento de aulas de leitura e de escrita com imenso potencial dialógico. Não abandonamos a leitura no suporte papel, mas apenas coadjuvamos o papel com o digital. Nos termos de Soares $(2002,150)$ :

O texto no papel é escrito e lido linearmente, seqüencialmente - da esquerda para a direta, de cima para baixo, uma página após outra; o texto na tela - o hipertexto - é escrito e é lido de forma multilinear, multi-seqüencial, acionando-se links sem que haja uma ordem preferida. A dimensão do texto no papel é materialmente definida: identifica-se claramente seu começo e seu fim, (...) o hipertexto, ao contrário, tem a dimensão que o leitor lhe der (Soares, 2002, p. 150).

Percebe-se, logo, que o suporte digital traz novas maneira de ler. O texto impresso traz um condicionamento de leitura linear de início, meio e fim, enquanto que o hipertexto, norteado por uma deslinearidade, subverte a ordem fazendo do leitor o construtor de sua leitura. Entretanto, para isso, o leitor precisa desenvolver competências (meta)cognitivas para que tenha fluência em sua leitura como também em sua estratégia de navegação.

seja, "arquivo na rede". Surgiu em agosto de 1999, criado pelo norte-americano Evan Williams. 
As aulas presenciais, desde a primeira edição do projeto, sempre acontecem baseadas em um texto escrito, as discussões são implantadas pelo orientador e a turma, por sua vez, é dividida em 'grupos de responsabilidades'. Tudo gira em torno de uma grande 'brincadeira'. O grupo 1 fica responsável por formular perguntas sobre o texto direcionadas a toda a turma. O grupo 2, anota todas as respostas e divagações feitas pela turma durante as discussões. Em seguida, o grupo 1 escreve no blog educativo os questionamentos; e o grupo 2, escreve as respostas da turma toda, cabendo a um terceiro grupo entrar a fim de tecer considerações sobre o conteúdo exposto pelos grupos 1 e 2. Dessa forma, sem notar os grupos estão lendo, escrevendo e aguçando a curiosidade e o 'sacar' dos implícitos e das inferências. Um acordo silencioso foi travado pelos grupos, pois a cada aula os grupos são trocados e as funções acompanham essa troca. Portanto, o grupo que na semana anterior se responsabilizava pelos questionamentos, na semana seguinte se responsabiliza pelas considerações e assim sucessivamente. As aulas são atraentes e o número de faltas inexiste. O LALT já se encontra em um estágio mais amadurecido, no qual toda semana um grupo se responsabiliza por encontrar um texto motivador da aula, deixando de ser da responsabilidade do professor-orientador. Sendo assim, eles já conseguem dizer qual o texto é passível de gerar discussão e qual texto não é passível de ser o motivador da aula e das responsabilidades criadas ludicamente. É importante salientar, que a linguagem utilizada busca seguir as normas gramaticais da língua culta. Os alunos mostram um cuidado especial, isto é, não é utilizada a linguagem de emoticons, nem visualizamos a economia das letras nem o transgredir das 
normas, a maioria dos textos busca prepará-los para a tão esperada redação do ENEM, já que são alunos do último ano do ensino básico.

\section{Considerações Finais}

É perfeitamente sabido que no nosso País, a leitura praticada é tida como superficial e que nossos alunos não gostam de ler nem de escrever e, que as aulas de língua materna são sempre direcionadas para as tradicionais aulas de gramática. Buscando reverter esse quadro, 'lançamos mão' da cibercultura e mais precisamente do letramento digital que nos traz a prática da leitura e da escrita com novas configurações de cores. Talvez esteja no suporte digital, ou melhor, no hipertexto as cores que nos fará pincelar melhor o quadro da leitura e da escrita nas aulas de língua portuguesa. Essas nuanças de cores promovem, sem ter tido essa intenção inicial, uma visão inusitada para o ensino da língua. É o exercício cotidiano que resulta no desenvolvimento da competência leitora e escrita do aluno. Portanto, o meio atraente da cibercultura acaba por promover esse exercício. $\mathrm{O}$ aluno se sente chamado a ler os hipertextos, o que nem sempre acontece com as leituras solicitadas na sala de aula. E é justamente nesse detalhe da atração que o professor de língua deve reorientar o seu objeto de ensino, não se dedicando unicamente à gramática, mas promovendo aulas dinâmicas que pratiquem leitura, oralidade e escrita. $\mathrm{O}$ (ciber) espaço oferece a seus exploradores temas, idéias e lugares variados, permite que escolham links e produzam, inevitavelmente, inferências e descubram implícitos ricos em informatividade. Em outras palavras, é esse tipo de leitor 
que os indicadores de avaliação desejam, um leitor capaz de interpretar e vivenciar seu direito de ser cidadão, por saber ler ativamente com todos os implícitos que as situações, por ventura, ocultarem. Considerando esse panorama de tecnocracia, e com intuito de contribuir para um melhor desenvolvimento da competência de leitura dos alunos no processo ensino/aprendizagem nos dedicamos à criação de um blog que redimensionasse as aulas de leitura, de escrita e de gramática, não esquecendo da oralidade.

Não se trata de supervalorizar o suporte, mas sim de perceber sua influência nas interações contemporâneas, e cabe ao professor de língua portuguesa repensar seus conteúdos e estratégias para que de fato ocorra aprendizagem significativa tanto de leitura como de escrita, de oralidade e de gramática conseguindo assim retirar o aluno do marasmo de não saber ler e escrever com habilidades suficientes e proporcionar de fato a esse aluno estar em um sociedade e se sentir cidadão.

\section{Referências}

AUTHIER-REVUZ, Jacqueline. "Heterogeneidade(s) enunciativa(s)". Cadernos de Estudos Lingüísticos 19. Campinas: UNICAMP, 1990.

BAKHTIN, Mikahil. Marxismo e Filosofia da Linguagem. São Paulo: Hucitec, 1990.

BRANDÃO, Helena H. Nagamine. In. Introdução à análise do discurso. 4 ed. Campinas, SP: Editora da UNICAMP, 1995. 
BAKHTIN, M. Estética da criação verbal. Trad. Do russo por Paulo Bezerra. 4. ed. São Paulo: Martins Fontes, 2003.

CARDOSO, Silvia Helena Barbi.(1994a). “A propósito da questão da referência". In. Estudos Lingüísticos XXIII, p. 576-583.

GALLO, Solange Leda. Texto: como apre(e)nder essa matéria? (Tese apresentada ao Departamento de Lingüística do Instituto de Estudos da Linguagem da Universidade Estadual de Campinas (Unicamp), 1994.

GUERRA VICENTE, Helena S. Relações de gênero social e democracia na internet. (Dissertação Inédita apresentada a UnB, 2000)

GUIMARÃES, E. "Enunciação, Argumentação e Interdiscurso". In. Anais do IX Encontro Nacional da ANPOLL - Lingüística - Vol.2, p. 705-709, 1995.

KOMESU, F. C. Blogs e as pra ticas de escrita sobre si na Internet. In:

MAINGUENEAU, Dominique. Novas tendências em análise do discurso. $3^{\mathrm{a}}$ ed., Campinas: Ed. da Unicamp, Pontes, 1997.

MARCUSCHI, L. A. e XAVIER, A. C. (Orgs.). Hipertexto e gêneros digitais: novas formas de construção do sentido. Rio de Janeiro: Lucerna, 2005.

KLEIMAN, A. B. Modelos de letramento e as práticas de alfabetização na escola. In: Os significados do letramento. Campinas: Mercado de Letras. 
LÉVY, P. Cibercultura. São Paulo: Loyola, 1999.

LOPES, Iveuta de Abreu. Cenas de letramento sociais. Recife. Programa de Pós-graduação em Letras da UFPE, 2006.

MARCUSCHI, L. A. e XAVIER, A. C. (Orgs.). Hipertexto e gêneros digitais: novas formas de construção do sentido. Rio de Janeiro: Lucerna, 2005.

MEY, Jacob L. As vozes da sociedade - letramento, consciência e poder. Trad. Ana Cristina Aguiar. Campinas: Mercado de Letras, 2001.

PÊCHEUX, Michel (1969). “Análise automática do discurso (AAD-69)". In: GADET \& HAK (org.). Por uma análise automática do discurso. $3^{\text {a }}$ ed., Campinas: Ed. da Unicamp, 1997.

POSSENTI, Sírio. "Apresentação da análise do discurso". Glotta. Vol. 12. São José do Rio Preto: UNESP, 1990.

RAMAL. Andréa Cecília. Educação e cibercultura: hipertextualidade, leitura, escrita e aprendizagem. Porto Alegre: Artmed, 2002.

SILVA, E.T. A Leitura nos oceanos da internet. São Paulo: Cortez, 2003.

SOARES, M. B. Novas práticas de leitura e escrita: letramento na cibercultura. In: Educação e Sociedade/Centro de Estudos Educação e Sociedade - Vol. 23, n. 81. São Paulo: Cortez: Campinas: Cedes, 2002. 
TURKLE, Sherry. Life on the screen: identify in the age of the Internet. Touchstone, New York, NY, 1995.

VALENTE, André. Aulas de Português: Perspectivas inovadoras. Petrópolis, Rj: Vozes, 1999.

VELLASCO, Ana Maria de M.S. O tipo de modalidade de discurso em uma lista de discussões de brasileiros na Internet. In. Cadernos de linguagem e sociedade. 3(2), pp. 101-104, 1999. 



\title{
A INTERAÇÃO EM AMBIENTE VIRTUAL DE APRENDIZAGEM: um estudo de caso
}

\author{
Aline Tavares Costa ${ }^{1}$ \\ Filomena Maria Gonçalves da Silva Cordeiro Moita ${ }^{2}$
}

\section{Introdução}

A instituição escolar oferece, em seu rol de objetivos voltados a formação de um cidadão consciente e ativo em comunidade, a perpetuação dos conhecimentos até então documentados, reunindo etapas e processos sistematizados, que abrigam diversos artefatos tecnológicos. A comunicação, neste ambiente, ocorre em diversas vias, e utiliza, também, diversas tecnologias, evidenciando a complexidade do sistema.

Estando a sociedade atual em um estágio avançado de desenvolvimento digital, tornando suas atividades em processos automatizados, é preciso que existam

1 Mestre em Formação de Professores. Professora substituta do Departamento de Computação da Universidade Estadual da Paraíba - UEPB. Tutora virtual do curso de Licenciatura em Computação, da Universidade Federal Rural de Pernambuco - UFRPE.

2 Doutora em Educação Comunicação e Cultura. Docente do quadro permanente do Programas de Pós-Graduação em Formação de Professores e Ensino de Ciências e Educação Matemática da Universidade Estadual da Paraíba - UEPB. 
indivíduos preparados para, não só utilizar adequadamente cada solução, como também criar novas. As gerações nascidas durante as várias revoluções tecnológicas (fogo, papel, imprensa, internet etc.) possuem características próprias, que facilitam a adaptação aos novos processos, mas que, por outro lado, podem dificultar as relações com os grupos nascidos em outros momentos.

Possíveis entraves podem ser encontrados na mais básica forma de comunicação - a oral. Por muito tempo, essa foi a única forma de interação, e, a todo instante, agrega novos vocábulos das tribos, podendo dificultar a compreensão, inclusive entre seus próprios membros. A escrita também herdou este fenômeno, assim como as tecnologias posteriores, que passaram a criar seus próprios códigos.

A internet, como meio interativo, global e eletrônico, permitiu a congruência desses códigos e o livre acesso a qualquer grupo que se interessasse, o que melhora e acentua a complexidade das novas linguagens. Os recursos digitais também influenciam, pois permitem a utilização de formatos e suportes informacionais específicos, como imagens, vídeos, áudio, emoticons etc.

Para os órgãos padronizadores de processos, como a escola, esta situação pode ser vista como caótica. No entanto, os grupos envolvidos criam no caos a sua própria ordem, ao manipular diversas informações simultaneamente, habilidade muitas vezes podada pela fala do professor. Os alunos, então, encontram liberdade para expressar-se a partir dos recursos digitais online, como nas redes sociais e nos games.

Neste cenário, tem-se buscado formas de aproximar esses dois mundos, com cursos de atualização sobre 
novas tecnologias e dinâmicas pedagógicas, por exemplo, para capacitar os educadores a encontrar formas de envolver o aluno. Um exemplo disso foi o curso de Pós-Graduação Latu Senso "Fundamentos da Educação: Práticas Pedagógicas Interdisciplinares", promovido pelo Governo do Estado da Paraíba, em parceria com a Universidade Estadual da Paraíba, entre 2013 e início de 2015, que se mostrou um espaço de discussão sobre pluralidade cultural, cidadania, tecnologias educacionais etc. Algumas disciplinas foram ministradas online, pelo Moodle, configurando o curso como b-learning, ou seja, com aprendizagem mista, híbrida, pois faz uso de ferramentas online, em parceria com ensino presencial.

A educação online permite o compartilhamento de saberes entre pessoas de localidades fisicamente distantes, portanto culturalmente distintas, provendo, inclusive, o retorno de muitos aos estudos. Docentes, neste novo ambiente, vestem-se de outras práticas, guiam o aluno por atividades em processos de construção de sentidos. Os jovens já descobriram as potencialidades desses recursos, interagem e são produtores de conhecimento, sendo necessário que os educadores orientem a produção, em busca do máximo aproveitamento.

Com este cenário, o presente trabalho objetiva expor um estudo de caso sobre a interação em ambiente virtual de aprendizagem, num curso na modalidade b-learning, que levou em consideração a linguagem utilizada na interação professor-aluno. Para tal, foram observados os diálogos de dois fóruns do módulo de Comunicação e Linguagem, a fim de analisar como o professor mediador e os professores-alunos fazem uso da linguagem para se expressar neste ambiente. 


\section{Interação b-learning na escola}

A voz foi uma das primeiras tecnologias utilizadas pelo homem em suas relações, que, destituídas de qualquer sistematização de métodos e processos, ocorriam de forma natural e instintiva. Com o desenvolvimento de outras tecnologias, formas diversas de interação foram sendo integradas, caracterizando momentos de revolução. No caso da linguagem, essas revoluções são tidas como vagarosas e sutis (CRYSTAL, 2005), pois precisam firmar presença nas práticas sociais de uma comunidade, adequando-se para servir às necessidades de comunicação que possam surgir (SHEPHERD e SALIÉS, 2013). Por outro lado, atualmente, o nascimento de criações linguísticas, mesmo com base nas já existentes, é mais frequente.

Uma das primeiras adaptações ocorreu com a representação da oralidade na escrita, com a criação de signos para determinar pausas, entonações, volume da voz, além da utilização de espaços em branco para organização da mensagem em períodos lexicais e sintáticos. Para Marcuschi (2001), a oralidade destinou-se a ser prática social com fins comunicativos, fundamentada na realidade sonora, enquanto que a escrita é um modo de produção textual-discursiva, constituída por simbologia gráfica e/ou pictórica, na qual marcas de pontuação, letras maiúsculas e espaços são utilizados para determinar o limite de cada palavra numa oração (BRAGA, 2013).

Independentemente dos meios utilizados, a sociedade encontrou formas de se comunicar, porém, durante esse processo, foi preciso que os indivíduos conhecessem o código para compreender as mensagens. Inicialmente, apenas conhecer os signos e as construções lexicais foi 
suficiente, porém variantes contextuais passaram a influenciar a compreensão da mensagem. $O$ contexto passou a ser determinante na identificação/uso das linguagens (na comunicação), pois reúne informações que revelam características do grupo que interage, as chamadas pistas de contextualização (GUMPERZ, 2002).

$\mathrm{O}$ processo interacional pode ser descrito, portanto, pelo envolvimento de pelo menos duas pessoas, com objetivo e/ou conhecimento prévio em comum, e que dividem momentos de locução e interlocução, numa mútua construção de sentido. As representações contextuais não verbais influenciam a produção verbal, quando se constrói uma fala tomando a do outro como base (FÁVERO et al., 2010). Este processo envolve um fenômeno de figuração, que utiliza representações dos interlocutores, de acordo com a necessidade do momento (KOCH, 2006), alternando suas faces, em função do ambiente, das pessoas ao redor, das atividades a serem realizadas etc..

Nos espaços escolares, os incentivos à comunicação são frequentes, principalmente por sua heterogeneidade; e, considerando a construção de referências pessoais após a troca comunicacional em um grupo (PRADO e ALMEIDA, 2007), entende-se que um pouco de cada membro passa a fazer parte do outro, como aprendizado, ainda que imperceptivelmente. $\mathrm{O}$ resultado do processo de interação, ou seja, o aprendizado, evidencia a importância de incentivar a colaboração e o compartilhamento de conhecimentos naquele espaço escolar. De acordo com os autores, a rede de aprendizagem constitui-se complexa por considerar o contexto dos indivíduos, com sua linguagem, cultura, visão de mundo, dos outros e de si próprio. 
Tratando-se de contexto, os alunos do século XXI vivenciam práticas dialógicas amparadas por suportes informacionais geralmente distintos dos utilizados por seus professores. Esses dois grupos, em ambientes online, por exemplo, podem compartilhar suas experiências e contribuir com suas próprias formações, rumo a criação de uma comunidade. O comprometimento do membro ao grupo é alcançado quando há uma partilha de interesses em comum e quando as regras e normas pré-estabelecidas são incentivadas e respeitadas.

As comunidades escolares atuais, no entanto, possuem elementos que pouco tem despertado o interesse dos alunos, como a padronização do currículo, do livro didático e das atividades escolares. Os ambientes online podem ser personalizados para atender a estes elementos, porém segundo a relevância estabelecida pelos discentes. A educação a distância é resultado dessa democratização, pois, ao aluno, é permitido estudar e formar-se usando a tecnologia impressa, radiofônica, televisiva ou digital-online (MOORE e KEARSLEY, 2007), sem deslocar-se até a instituição formadora.

É importante ressaltar que, como apontam Palloff e Pratt (2013) e Prado e Almeida (2007), ensinar online não é um simples processo de transposição das práticas presenciais para o meio digital, uma vez que "induz a perder elementos específicos fundamentais da presencialidade" e "não incorpora as características dos recursos do ambiente virtual" (PRADO e ALMEIDA, 2007, p. 68).

Neste sentido, a cultura atual converge em sentidos diversos, num sistema multissemiótico de textos, imagens, sons, vídeos, hiperlinks, animações, emoticons, simulações 
e games, permitindo, por fim, a criação de mensagens semanticamente ricas (MOITA, 2007). Os artifícios utilizados para suprir a falta da entonação da voz, dos gestos e até do próprio silêncio compõem o que Crystal (2005, p. 89-90) chamou de netspeak, "mais compreendido como uma linguagem escrita que foi empurrada em direção à fala do que uma linguagem falada que foi escrita". Para o autor, o netspeak é mais que um conjunto de características da fala e da escrita, precisa ser visto como uma nova forma de comunicação, um novo veículo, pois suas mensagens possuem fluidez, simultaneidade e não perdem seu valor pelas cópias realizadas.

Há, no entanto, um dilema enfrentado pelos grupos que desejam utilizar-se do meio digital: precisam aprender regras que não existem, "no sentido de modos de comportamento universalmente aceitos e estabelecidos pelo uso de gerações" (CRYSTAL, 2005, p. 79). A ausência de limites sobre a criatividade em elaborar códigos linguísticos, de certa forma, força a ampliação dos conhecimentos do receptor, que busca decifrar a mensagem e extrair dela todos os possíveis sentidos.

Como contribuição à discussão, Madalena (2013) lembra mais dois pontos importantes: 1) a simbologia imagética e a contração de palavras, muitas vezes, são justificadas pela necessidade de escrita rápida, em comunicações em tempo real, contudo, quando em situações assíncronas, pode se tornar "uma falta de cortesia obrigar o leitor a um esforço desnecessário de decodificação da mensagem" (MADALENA, 2013, p. 47); mas, por outro lado, 2) os códigos podem ser considerados linguagens universais, compreendidas por grupos de línguas maternas distintas. 
Para Crystal (2005), existem três diferenças básicas entre a conversa face a face e a mediada por computador: a) a interação presencial possui retorno instantâneo, ainda que não seja em locução, os interagentes reagem instintivamente; b) é possível, em ambiente virtual, conduzir um número significativamente maior de conversas simultâneas; e c) "as limitações temporais da tecnologia: o ritmo de uma interação na Internet é muito mais lento do que o de uma situação de fala, e invalida algumas das propriedades mais evidentes de uma conversa" (CRYSTAL, 2005, p. 82). Para o autor, alguns dos fatores que influenciam tal ritmo são o computador, a personalidade e os hábitos do interlocutor em relação ao próprio acesso ao equipamento.

Quanto à tipografia da escrita em meio digital, Crystal (2005) identificou três características: a) a letra maiúscula, muitas vezes ausente por significar uma interação a mais com o teclado, não é prática comum, mas, quando ocorre, pode representar uma "forma marcada de comunicação" (op. cit., p. 93), como gritos ou ênfase ao que está sendo dito; b) a pontuação costuma ser "truncada" pela velocidade na digitação ou por escolha, provocando ambiguidades na mensagem (como em "estou com dificuldades de tirar dúvidas. a atividade IV estou com problemas. algumas respostaaaaaaa"3); e c) a grafologia da internet, que sintetiza também as combinações de símbolos, como as reticências para expressar pausa ou o excesso de sinais de pontuação indicando urgência na afirmação ou no questionamento ("Gostaria de ter acesso as notas, como faço???"4).

3 Exemplo retirado do curso de Pós-Graduação analisado

4 Exemplo retirado do Curso de Pós-Graduação analisado 
Esses registros interacionais culminam na persistência da mensagem (CRYSTAL, 2005), possível apenas em ambientes online. Os interlocutores, mesmo os ingressantes após o início da conversa, podem ter acesso ao diálogo completo, retornar ao assunto ao emitir suas impressões ou permanecer em silêncio. Este é um recurso de auxílio ao professor, por exemplo, que busca avaliar seus alunos durante o processo de aquisição de conhecimento, com base na ação interacional.

\section{A formação docente online}

O professor de ensino presencial, que, segundo Moran (2007), assume papeis previsíveis, mosaicos, papagaios e desesperançadores, precisa lidar, no ensino online, com uma interação relativa e com a ausência simultânea dos membros do grupo, levando à autonomia do aluno quanto ao momento do estudo, ao momento da avaliação e ao material consultado. Esses itens, identificados como diálogo, autonomia e estrutura, fazem parte da tríade relacional definida pela Teoria da Distância Transacional (MOORE e KEARSLEY, 2007), que determina o distanciamento emocional resultante da combinação daqueles itens, conforme apresentado a seguir.

Relação entre estrutura, diálogo e distância transacional

\begin{tabular}{|c|c|c|}
\hline Estrutura & Diálogo & Distância transacional \\
\hline Muito & Pouco & Grande \\
\hline Pouco & Muito & Pequena \\
\hline
\end{tabular}


Neste quadro, autonomia e distância apresentam-se diretamente proporcionais (quanto mais autônomo, mais independente - distante - do sistema o aluno será), em detrimento do nível de diálogo estabelecido, que aproximará os envolvidos no processo. Segundo Peters (2006), o diálogo vai além da função de aproximação ou de recurso para auxiliar os alunos:

Atualmente, a participação no diálogo ativa e intensifica a reflexão sobre problemas científicos. Trocando ideias diferentes, colocando opinião contra opinião, assumindo posições, pondo sempre de novo em dúvida conclusões e exercendo crítica, os estudantes adquirem nova relação com o conteúdo discutido, ao contrário do que ocorre quando tomam conhecimento dele apenas por leitura e reflexão e somente assimilam verdades. $\mathrm{O}$ interesse no objeto aumenta: reconhece-se um grau mais elevado de envolvimento, que pode chegar até o engajamento (PETERS, 2006, p. 78)

A prática online do professor e do aluno dependerá do nível de envolvimento/engajamento com a proposta, e com seus pares. Para tal, Palloff e Pratt (2013) definiram cinco fases do desenvolvimento do docente, identificadas no reconhecimento de sua descrição: a) o visitante não possui grande afinidade com a tecnologia, porém a experimentou e achou curiosa a integração de práticas; 
b) o principiante nunca lecionou online, mas já utilizou o espaço para disponibilizar materiais ou comunicar-se com os alunos; c) o aprendiz desenvolve maior compreensão do ambiente online, pois já passou por experiências de ensino utilizando esse ambiente; d) o iniciado é proficiente no gerenciamento de cursos, além de reunir habilidades necessárias ao ensino e ao design desses cursos; e) o mestre possui conhecimentos suficientes para utilizar recursos além dos ofertados pelo sistema, auxiliando os profissionais iniciantes.

Para que haja avanço entre essas fases é necessário treino, conhecimento e aprofundamento, ou seja, uma formação diferenciada, visando "assegurar alto grau de interatividade e participação, o que significa elaborar e conduzir atividades de aprendizagem que resultem em envolvimento com a disciplina e com os colegas" (KEARSLEY, 2011, p. 81). O profissional, portanto, precisa envolver-se com a proposta de tal forma a transmitir aos alunos segurança e confiança na aprendizagem, além de ser

organizado; altamente motivado e entusiasmado; comprometido com o ensino; apoia a aprendizagem centrada no estudante; aberto a sugestões; criativo; assume riscos; gerencia bem o tempo; atento às necessidades dos alunos; disciplinado; interessado no ensino online sem nutrir expectativas por outras recompensas. (PALLOFF e PRATT, 2013, p. 26) 
É evidente que, além da didática do profissional, existem estratégias específicas para cada ambiente de aprendizagem, que se utilizam dos seus recursos disponíveis. Um curso b-learning (aprendizagem misturada), por exemplo, pode fornecer suporte presencial às atividades virtuais ou vice e versa, usufruindo diretamente do melhor que os dois ambientes tem para oferecer, além de diminuir o impacto da aprendizagem totalmente destituída de presença física.

Esta dinâmica é prevista em Lei, pela Portaria ${ }^{\circ} 4.059$, de 10 de dezembro de $2004^{5}$, e permite a inserção de disciplinas na modalidade semipresencial em cursos de graduação, apoiadas por suportes de cunho tecnológico remoto, não ultrapassando $20 \%$ da carga horária total do curso. Essa possibilidade abre espaço para novas experiências e discussões, deixando a cargo das instituições a adoção de práticas a distância ou não.

O interesse do educador pode surgir em sua própria vivência como coprodutor virtual de saberes, ao perceber as potencialidades da união do ambiente online com o offline. De acordo com Alves (2007, p. 118), professores participantes de um curso de formação, "tendem a reproduzir o modelo vivenciado como aluno", numa intervenção de ordem reflexiva. A formação necessária para um curso b-learning pode nascer da própria experiência do professor enquanto aluno, pois perceberá as necessidades, as curiosidades e o processo de desenvolvimento cognitivo.

5 Disponível em < http://portal.mec.gov.br/sesu/arquivos/ pdf/port4059-2004.pdf > Acesso em 27 de março de 2015 
Sendo colaborativa, a aprendizagem docente, para Bolzan e Isaia (2010), configura-se no processo de apreender a partir da análise e na interpretação das suas atividades, de seus colegas e dos próprios alunos. Aqui, o principal aspecto a ser considerado é a compreensão da necessidade constante de atualizações, afinal o ambiente de trabalho deste profissional é, por função social, um espaço de aprendizagem. O educador precisa ser receptivo às novas formas de constituir o conhecimento específico e o pedagógico experimental (BOLZAN e ISAIA, 2010).

A formação continuada de professores surgiu com a necessidade de, entre outros aspectos, compensar a formação inicial, incluindo atividades discursivas de autoavaliação, de ordem pedagógica, técnica ou tecnológica. A urgência desses momentos está relacionada ao aumento da escolarização da população, à sua inserção no mercado de trabalho mundial (OLIVEIRA, 2012) e à busca por profissionais da educação mais flexíveis e versáteis, que acompanhem as exigências sociais atuais.

Segundo Filatro (2010), há uma forte tendência ligando a educação online a um processo descontextualizado, pois atende um grande número de pessoas em situações geográfica, social e culturalmente distintas. Por este mesmo motivo, no entanto, esta educação apresenta um leque de possibilidades de crescimento pessoal e profissional, inclusive atendendo àquelas exigências sociais, ao efetivar os saberes construídos num contexto em rede. A "desterritorialização do ensino vem acompanhada também por transformações no perfil daqueles que aprendem: adultos amadurecidos pelas experiências de vida e do trabalho, ou gerações mais novas moldadas em uma sociedade mediada por tecnologias" (FILATRO, 2010, p. 36). 
A aliança entre o ensino online e a formação continuada de professores tem obtido êxito, por resultar em custo-benefício positivo para instituições formadoras (públicas ou particulares), ao passo que atinge um volume massivo de profissionais, inclusive em serviço. Diante disto, podem-se identificar três potenciais efeitos: a) a apresentação de alternativas para estabelecer contato além-classe com os alunos, permitindo envolvimento afetivo, aspecto importante para o relacionamento e a construção de confiança mútua entre professor e aluno; b) a novidade que isso representa, como proposta para dinamização dos momentos presenciais; e c) a diminuição da resistência e do medo de experimentar as inovações tecnológicas.

A relevância de intensificar a convergência das mídias nos processos de formação docente (inicial ou continuada) é justamente para barrar a tendência à reprodução dos alunos quando em suas funções profissionais, tornando-os mais seguros para explorar as opções em metodologias e recursos de suporte inovadores.

\section{Percurso metodológico}

O estudo de uma cultura, sob o ponto de vista qualitativo, recebeu o nome de etnografia, e tem foco no processo da descrição do ambiente, não no resultado (ANDRE, 2008). Quando essa cultura manifesta-se também em ambientes virtuais, novos aspectos devem ser considerados, ainda que, segundo Amaral (2010), os espaços online e offline sejam indissociáveis, por compartilharem seus objetos centrais: os indivíduos. Esses novos aspectos são nomeados e descritos pela netnografia, e, para Kozinets (2014, p. 61-62), define-se como uma "pesquisa 
observacional participante baseada em trabalho de campo online", ou seja, exige que o pesquisador envolva-se com a comunidade estudada, para que seja possível descrevê-la e interpretá-la fielmente, a partir de instrumentos como entrevistas online, e-mails, postagens e sites (AMARAL, NATAL e VIANA, 2008; e ROCHA e MONTARDO, 2005).

O ambiente virtual analisado objetivou a formação continuada de profissionais da educação do Estado da Paraíba, em parceria com a Universidade Estadual da Paraíba, num curso de Pós-Graduação Lato Sensu em Fundamentos da Educação: Práticas Pedagógicas Interdisciplinares. A proposta seguiu em eixos temáticos (Educação e Identidade; Educação e Tecnologia; Educação e Campo; Educação e Cidadania; Educação e Cultura; Educação e Cidade; Educação e Comunicação; Educação e Trabalho; e Educação e Pesquisa) de forma modularizada, atendendo a cada segmento.

As aulas presenciais (200 horas) ocorreram aos sábados, em polos localizados em cidades paraibanas, e os encontros a distância, no ambiente virtual de aprendizagem (Moodle), com 160 horas, levando os 3.159 professores $^{6}$ a vivenciar uma experiência totalmente nova para muitos. Houve também distribuição de material didático e realização de um momento presencial de ambientação para a utilização do Moodle.

Dentre os módulos do curso, foi escolhido o de Comunicação e Linguagem e a Turma 5 (Paulo Freire). Este módulo durou cinco semanas temáticas (de 1으 de agosto a 5 de setembro de 2013), e a terceira ("A escola,

6 Disponível em < http://ead.uepb.edu.br/noticias,487 > Acesso em 21 de abril de 2015. 
nativos digitais e suportes digitais") forneceu os diálogos aqui analisados e categorizados.

Esse processo ocorreu sem referência prévia, pois são dados extraídos de documentos virtuais, que induzem à elaboração de códigos ou categorias a partir de uma leitura mais atenta, servindo como rótulos ou exemplos do fenômeno descrito (KOZINETS, 2014). As categorias identificadas foram "Saudação Inicial", "Interação" e "Encerramento da Mensagem", com subcategorias, dependendo da discussão. Foram também observados quantidade de postagens do professor mediador e dos alunos, o uso da linguagem formal e da netspeak ${ }^{7}$, o conteúdo dos comentários (nível da reflexão e elementos da mensagem) e a disposição dos alunos em interagir. Não houve exposição de nomes ou de informações que pudessem constranger ou intimidar os participantes.

\section{A voz do Docente enquanto Discente}

Como mecanismo de defesa, o ser humano, ao se deparar com uma situação nova, tende a resistir ao enfrentamento, preservando-se diante do desconhecido. No entanto, esse desconhecido reúne oportunidades de aprendizagem, que levam o indivíduo para além de sua zona de conforto, desafiando a construção de novos conceitos ou o reestabelecimento dos existentes.

7 Segundo Crystal (2005), uma nova forma de comunicação em ambientes virtuais, que agrega fluidez, simultaneidade em diferentes combinações de códigos. 
O grupo estudado nesta pesquisa, por exemplo, é proveniente de um curso de formação continuada b-learning para educadores, sendo que, para muitos deles, a comunidade virtual é um ambiente desconhecido. Diante disto, os estímulos e o suporte para promover o engajamento ao grupo precisaram ser intensos, na utilização de recursos digitais de fácil manuseio e diálogos amigáveis.

Durante a semana analisada, foram disponibilizados alguns arquivos: (a) uma apresentação da disciplina em formato de áudio; (b) dois materiais de leitura ("Nativos digitais x Aprendizagem: um desafio para a escola" e "Nativos digitais versus imigrantes digitais: a controvérsia"); (c) uma apresentação de slides abordando o tema; e (d) um vídeo intitulado "Conheça o aluno multimídia".

O fórum foi classificado como Atividade, com o seguinte enunciado: "Faça uma leitura crítica das diferentes linguagens apresentadas nesta semana e escreva no fórum uma frase reflexiva com 2 linhas. [link para o fórum: Fórum]". O acesso a esse item não possui indicação direta nos materiais de leitura ou na apresentação de slides, o que facilitaria o fluxo das ações, sendo necessário voltar à página inicial para acessá-lo.

Com esses dados, percebe-se a intenção de promover o reconhecimento da identidade e do formato do curso a ser iniciado. Os alunos precisam perceber e ter acesso ao planejamento do curso, com os objetivos pretendidos e as habilidades e competências esperadas, ao final do percurso (MOORE e KEARSLEY, 2007; PETERS, 2006). É importante, também, que essa apresentação seja amigável, objetiva e dinâmica, para despertar e manter a atenção e a curiosidade do participante. 
A primeira postagem do mediador da turma Paulo Freire foi composta pelo texto oficial da Atividade, com o objetivo da discussão e a quantidade máxima de linhas para a resposta, porém sem elementos de saudação inicial ou final e assinatura.

Primeira postagem do mediador da Turma 5

Além desta, o professor mediador participou mais duas vezes. Na primeira delas, parabenizou os alunos, motivando-os com uma linguagem coloquial - buscando a construção de vínculos afetivos (KERCKHOFF, 2014, p. 31) -, e sem erros gramaticais ou de digitação: “Muito bem, pessoal. Muito bem mesmo! Estou gostando do nível dos comentários.". Além disto, comentou sobre o que foi discutido até então ("Tenho uma pequena observação sobre alguns pontos de vistas"), mas sem identificar os alunos a quem se referia. Percebe-se o teor reflexivo da postagem em questionamentos, como "Por que eu digo isso?" e "Não concordam?", e a busca por incluir-se ao grupo, por meio da conjugação dos verbos na terceira pessoa do plural ("nós devemos direcionar o aprendizado", "Então, somando todo o nosso conhecimento").

A última postagem manteve o padrão da linguagem coloquial e o respeito às normas gramaticais, mas explorou um pouco mais os recursos linguísticos, como as reticências, indicando surpresa e admiração em 
"Pessoal... sem palavras." e as letras maiúsculas na palavra "todos" ("Estou muito satisfeito com o desempenho de TODOS vocês"), amplificando/destacando seu sentido (MADALENA, 2013). O conteúdo desta mensagem foi de cunho motivacional e de reconhecimento pela participação dos alunos, quando explicitou seu orgulho pelo nível de interação da turma. A postagem finaliza com uma solicitação da opinião dos alunos sobre o novo formato do fórum.

As respostas aos comentários do mediador envolveram concordância com sua opinião, relatos de experiências sobre o tema, agradecimentos exaltados por excesso de exclamações e confirmação da importância da participação naquela discussão ("Muito legal o fórum, parabéns por fazer parte do mesmo junto conosco." e "Estou muito feliz com o seu comentário, estou realmente muito satisfeita por fazer parte deste grupo."), autoavaliação ("escrevi pouco, mas consegui ler quase todas as interações"), cumprimentos pela organização e pelo curso, e alunos cobrando a participação dos colegas, utilizando aspas e negrito para chamar a atenção ("vamos 'lembrar' aos nossos colegas de participarem desse fórum e contribuírem com as trocas cognitivas para que possamos enriquecer cada vez mais nossas práticas pedagógicas!").

Foram realizadas 204 postagens no fórum, contabilizando 306 respostas, das quais 51 eram repetições, que podem estar relacionadas a questões técnicas, como lentidão da conexão, que dá a impressão de não envio da resposta (demora um pouco para aparecer na tela), levando o aluno a clicar diversas vezes para enviar. Algumas respostas (98) ultrapassaram a orientação sobre a quantidade máxima de linhas, o que leva a um ponto de reflexão: se 
há uma orientação sobre como responder uma atividade, os alunos deverão segui-la à risca, exercitando habilidades específicas, como a de organização direta e objetiva das ideias; porém o nível de interação dos participantes pode ser maior quando há exposição de suas opiniões com clareza e riqueza de detalhes.

Alguns participantes se destacaram assumindo um papel provocador num processo de aprendizagem docente colaborativa (BOLZAN e ISAIA, 2010):

Situações de interação no fórum

\begin{tabular}{|c|c|}
\hline \multicolumn{2}{|r|}{ Situação 1 - Burocracia auxilia ou atrapalha? } \\
\hline$[\mathrm{A}]$ & $\begin{array}{l}\text { "Colegas, o grande problema é que a escola está as margens } \\
\text { das múltiplas oportunidades tecnológicas extra território } \\
\text { escolar.Não será a burocracia a grande vilã? Os tablets?" }\end{array}$ \\
\hline [B] para $[\mathrm{A}]$ & $\begin{array}{l}\text { "De forma alguma professora [A], estas "burocracias" } \\
\text { são apenas ferramentas para facilitar e acelerar nossa } \\
\text { aprendizagem e consequentemente à do nosso aluno. } \\
\text { Antes, os alunos tinham que ir fazer pesquisas nas } \\
\text { bibliotecas,desarrumavam uma pilha de livros e hoje nada } \\
\text { disso mais é preciso, sem contar que na webquest ele } \\
\text { encontra excelentes leituras, pode ir à inúmeras bibliotecas } \\
\text { virtuais sem sair de casa." }\end{array}$ \\
\hline \multicolumn{2}{|r|}{ Situação 2 - Familiaridade com a tecnologia } \\
\hline$[\mathrm{A}]$ & $\begin{array}{l}\text { "Atualmente os jovens são os primeiros a se inserir nas } \\
\text { tecnologias digitais de comunicação, permitindo está } \\
\text { interligado com a sociedade contemporânea." }\end{array}$ \\
\hline$[\mathrm{B}]$ para $[\mathrm{A}]$ & $\begin{array}{l}\text { "E porque iniciam tão cedo ou já aprendem as peimeiras } \\
\text { letras no teclado,ao contrário de nós que aprendíamos } \\
\text { na boa e velha tabuada e do alfabeto plástico, são então } \\
\text { chamados de "Nativos Digitais"” }\end{array}$ \\
\hline$[\mathrm{C}]$ para $[\mathrm{B}]$ & $\begin{array}{l}\text { "É verdade professora [B],eles não vem limites,já nós...e } \\
\text { o que achas que deve ser feito para acompanharmos os } \\
\text { nativos digitais [B] ?" }\end{array}$ \\
\hline
\end{tabular}


Apesar de tímidas e pouco exploradas, as interações podem indicar um desejo por discutir o assunto naquele espaço, mesmo sem uma solicitação inicial ou um incentivo frequente a esta prática. A utilização de saudação, assinatura ou referência ao comentário de outros participantes também foi pequena. A seguir são descritas as formas iniciais de interação entre os participantes, com os rótulos criados a partir da leitura dos dados, sem uma codificação prévia (KOZINETS, 2014). A categoria "Saudação Inicial" reúne alguns textos encontrados no início das mensagens:

Categoria "Saudação Inicial"

\begin{tabular}{|c|c|c|}
\hline Subcategoria & Descrição/Função & Ocorrências \\
\hline $\begin{array}{l}\text { Chamamento } \\
\text { formal }\end{array}$ & $\begin{array}{l}\text { O uso dos vocativos "caro" e "prezada" } \\
\text { demonstram formalidade e cordialidade, } \\
\text { apesar de, em alguns casos, precederem } \\
\text { um substantivo informal. Nomear a quem } \\
\text { está se referindo pode indicar um canal } \\
\text { comunicativo direto, dentre as outras } \\
\text { interações. }\end{array}$ & $\begin{array}{l}\text { "Caros (a) } \\
\text { colegas"; } \\
\text { "Caros colegas!"; } \\
\text { "Prezada colega,"; } \\
\text { "Caro [nome do } \\
\text { mediador]," }\end{array}$ \\
\hline $\begin{array}{c}\text { Chamamento } \\
\text { informal }\end{array}$ & $\begin{array}{l}\text { Ainda que varie em número e em } \\
\text { direcionamento a uma pessoa ou ao } \\
\text { grupo, esses exemplos buscam um } \\
\text { maior nível de proximidade afetiva, } \\
\text { pois refletem expressões utilizadas em } \\
\text { diálogos presenciais. }\end{array}$ & $\begin{array}{l}\text { “Olá [nome]”; } \\
\text { “Olá colegas"; } \\
\text { “Oi pessoal!"; } \\
\text { "Colegas, [...]" }\end{array}$ \\
\hline $\begin{array}{c}\text { Misto de } \\
\text { chamamentos }\end{array}$ & $\begin{array}{l}\text { A junção das duas subcategorias } \\
\text { anteriores apresenta uma saudação } \\
\text { formal, mas que foi suavizada pela } \\
\text { palavra "amigos" e a exclamação. }\end{array}$ & $\begin{array}{l}\text { "Saudações } \\
\text { amigos!"; }\end{array}$ \\
\hline
\end{tabular}




\begin{tabular}{|c|l|l|}
\hline Subcategoria & \multicolumn{1}{|c|}{ Descrição/Função } & \multicolumn{1}{c|}{ Ocorrências } \\
\hline $\begin{array}{c}\text { Incentivo e } \\
\text { congratulações }\end{array}$ & $\begin{array}{l}\text { O cursista incentivador demonstra } \\
\text { familiaridade com o ambiente, pois o } \\
\text { faz sem que haja solicitação de terceiros } \\
\text { e tomam a iniciativa de parabenizar os } \\
\text { colegas, nomeando-os, ou não. }\end{array}$ & $\begin{array}{l}\text { "Parabéns } \\
\text { colega!"; } \\
\text { "Cara [nome], } \\
\text { parabéns por suas } \\
\text { colocações !"; }\end{array}$ \\
\hline Por turno & $\begin{array}{l}\text { A identificação do turno em que a } \\
\text { mensagem está sendo postada implica } \\
\text { cordialidade, mas, também, o momento } \\
\text { em que o aluno acessa o sistema. A este } \\
\text { fator é atribuído um sentido único da } \\
\text { mensagem, e ao recebê-la em outro turno, } \\
\text { o leitor poderá encontrar-se em conflito } \\
\text { com sua realidade. }\end{array}$ & $\begin{array}{l}\text { "Boa noite } \\
\text { pessoal."; } \\
\text { "Bom dia[nome } \\
\text { do mediador]!"; } \\
\text { "Caro [nome]. } \\
\text { Bom dia." }\end{array}$ \\
\hline
\end{tabular}

A seguir, as subcategorias de "Interação", considerando os conteúdos das mensagens e as menções aos membros do grupo, direta ou indiretamente.

Categoria "Interação"

\begin{tabular}{|c|c|c|}
\hline Subcategoria & Descrição/Função & Ocorrências \\
\hline $\begin{array}{c}\text { Questionamento } \\
\text { retórico }\end{array}$ & $\begin{array}{l}\text { Ainda que possa parecer um } \\
\text { questionamento retórico, a aluna abriu } \\
\text { espaço para discussão, solicitando a } \\
\text { opinião de um colega acerca de sua } \\
\text { própria condição, frente às tecnologias } \\
\text { digitais. }\end{array}$ & $\begin{array}{l}\text { "Companheiro, }[\ldots] \\
\text { será que um dia serei } \\
\text { uma nativa digital?" }\end{array}$ \\
\hline $\begin{array}{c}\text { Questionamento } \\
\text { direto }\end{array}$ & $\begin{array}{l}\text { Para incentivar a discussão do tema, } \\
\text { o autor dessa mensagem utilizou } \\
\text { de um simples e eficaz artifício: o } \\
\text { questionamento. }\end{array}$ & $\begin{array}{l}\text { "E como seria essa } \\
\text { transformação } \\
\text { professora }[\text { nome }] ? "\end{array}$ \\
\hline
\end{tabular}




\begin{tabular}{|c|c|c|}
\hline Subcategoria & Descrição/Função & Ocorrências \\
\hline $\begin{array}{c}\text { Concordância } \\
\text { ou discordância } \\
\text { direta (nominal) }\end{array}$ & $\begin{array}{l}\text { Esses exemplos demonstram a } \\
\text { participação dos membros do grupo } \\
\text { (concordando ou discordando), } \\
\text { contribuindo com a fala do outro e } \\
\text { construindo saberes coletivamente. } \\
\text { Nomear um colega, apesar de parecer } \\
\text { desnecessário, é importante para } \\
\text { intensificar o vínculo afetivo. Vale } \\
\text { lembrar que a utilização das palavras } \\
\text { "amiga" e "professor" indicam níveis } \\
\text { de empatia que podem ser decorrentes } \\
\text { do presencial. }\end{array}$ & $\begin{array}{l}\text { "De forma alguma } \\
\text { professora [nome],"; } \\
\text { "E eu, acredito } \\
\text { professora [nome] } \\
\text { que"; } \\
\text { "Concordo com } \\
\text { a amiga [nome] } \\
\text { quando"; }\end{array}$ \\
\hline $\begin{array}{c}\text { Agradecimento } \\
\text { direto (não } \\
\text { nomeado) }\end{array}$ & $\begin{array}{l}\text { Este intenso comentário, apesar de } \\
\text { não possuir um endereçamento, foi } \\
\text { realizado como resposta a algum } \\
\text { elogio. É possível concluir isto pela } \\
\text { organização mensagens, na qual uma } \\
\text { resposta é alocada logo abaixo da } \\
\text { postagem a que faz referência, com um } \\
\text { recuo à direita. }\end{array}$ & $\begin{array}{l}\text { “Fico feliz!!!! muito } \\
\text { obrigada!!!!" }\end{array}$ \\
\hline $\begin{array}{l}\text { Resposta direta ao } \\
\text { mediador }\end{array}$ & $\begin{array}{l}\text { Esses dois exemplos foram respostas } \\
\text { nomeadas ao mediador, que solicitou } \\
\text { a opinião dos alunos acerca do } \\
\text { novo formato do fórum. O uso dos } \\
\text { identificadores "professor" ou "prof" } \\
\text { demonstra respeito à posição do } \\
\text { mediador, mesmo todos sendo, por } \\
\text { profissão, também professores. }\end{array}$ & $\begin{array}{l}\text { "Prof. [nome do } \\
\text { mediador], gostei } \\
\text { desse novo modelo } \\
\text { de fórum,"; } \\
\text { "esse novo modelo } \\
\text { está excelente } \\
\text { professor." }\end{array}$ \\
\hline Incentivo à equipe & $\begin{array}{l}\text { A atitude de parabenizar a equipe } \\
\text { tem um teor motivacional importante } \\
\text { para o andamento do curso, uma vez } \\
\text { que este grupo necessita perceber } \\
\text { um retorno dos alunos quanto ao seu } \\
\text { trabalho, para continuar realizando-o. }\end{array}$ & $\begin{array}{l}\text { "Aplausos para } \\
\text { esta equipe } \\
\text { organizativa!" }\end{array}$ \\
\hline
\end{tabular}

\section{Por fim, a categoria "Encerramento da Mensagem" e suas subcategorias, elaboradas com a análise dos textos localizados ao final das mensagens.}


Categoria "Encerramento da Mensagem"

\begin{tabular}{|c|c|c|}
\hline Subcategoria & Descrição/Função & Ocorrências \\
\hline Nome da pessoa & $\begin{array}{l}\text { Variando em apenas o primeiro } \\
\text { nome e o nome completo ou } \\
\text { acrescentando "Prof", a incidência } \\
\text { desta subcategoria é baixa, levando } \\
\text { a crer que os alunos compreendem } \\
\text { a autoidentificação que o próprio } \\
\text { sistema fornece no ato da postagem } \\
\text { da mensagem. }\end{array}$ & [nome do aluno] \\
\hline $\begin{array}{l}\text { Despedida formal } \\
\text { ao grupo }\end{array}$ & $\begin{array}{l}\text { A abreviação da expressão } \\
\text { "Atenciosamente" (Att) denota } \\
\text { uma formalidade comum em troca } \\
\text { de e-mail, apesar de o formato } \\
\text { geralmente utilizar outro sinal de } \\
\text { pontuação ("Atenciosamente,", } \\
\text { "Att," ou "Att"). }\end{array}$ & "Att: [nome do aluno]" \\
\hline $\begin{array}{l}\text { Despedida } \\
\text { informal }\end{array}$ & $\begin{array}{l}\text { Seja no singular seja no plural, } \\
\text { individualmente ou para todo } \\
\text { o grupo, encerrar a mensagem } \\
\text { mandando abraços ou beijos } \\
\text { representa um nível de } \\
\text { envolvimento afetivo semelhante } \\
\text { ao que se encontra em encontros } \\
\text { presenciais, quando são realizados } \\
\text { ou apenas ditos na despedida. Os } \\
\text { exemplos podem ser interpretados } \\
\text { como uma finalização automática } \\
\text { e amigável da mensagem, para } \\
\text { que o seu conteúdo não se limite à } \\
\text { solicitação do fórum. }\end{array}$ & $\begin{array}{l}\text { “Abraço"; } \\
\text { "Abraços"; } \\
\text { "Um forte abraço."; } \\
\text { "Tenham todos uma } \\
\text { boa noite."; } \\
\text { “Abraços [nome do } \\
\text { aluno]. Fica com } \\
\text { Deus." }\end{array}$ \\
\hline
\end{tabular}




\begin{tabular}{|c|c|c|}
\hline Subcategoria & Descrição/Função & Ocorrências \\
\hline $\begin{array}{l}\text { Despedida } \\
\text { composta }\end{array}$ & $\begin{array}{l}\text { A união do desejo de sucesso } \\
\text { com uma referência de saudação } \\
\text { formal adaptada demonstra um } \\
\text { nível de elaboração acentuado, } \\
\text { descaracterizando uma } \\
\text { finalização automática. O aluno } \\
\text { fez também referência a sua } \\
\text { condição profissional, afirmando } \\
\text { envolvimento afetivo com a } \\
\text { atividade, ao incluir a expressão } \\
\text { "Saudações didáticas" na } \\
\text { despedida. }\end{array}$ & $\begin{array}{l}\text { "Muito sucesso na } \\
\text { caminhada! } \\
\text { Saudações didáticas," }\end{array}$ \\
\hline Despedida virtual & $\begin{array}{l}\text { Essa subcategoria é a única que, } \\
\text { em interações no mundo real, não } \\
\text { se adequaria, pois faz referência } \\
\text { direta ao ambiente online. Percebe- } \\
\text { se os autores preocuparam-se } \\
\text { com a elaboração da expressão, } \\
\text { principalmente em "Saudações } \\
\text { Neanderthal e boa viagem", que } \\
\text { reuniu uma saudação formal, uma } \\
\text { referência à espécie humana e uma } \\
\text { alusão à viagem que a experiência } \\
\text { online pode proporcionar. }\end{array}$ & $\begin{array}{l}\text { “Saudações virtuais"; } \\
\text { “Abraço virtual!"; } \\
\text { “Abraços virtuais."; } \\
\text { "Saudações } \\
\text { Neanderthal e boa } \\
\text { viagem!" }\end{array}$ \\
\hline
\end{tabular}

A partir dessas categorias e subcategorias, percebe-se o rico campo semântico em que os participantes do curso estão inseridos e que apontam em suas mensagens, ainda que possam desconhecer esse potencial. A maneira com que inicia ou finaliza uma postagem demonstra o nível de interesse e envolvimento do aluno naquele curso, bem como sua disposição em voltar à discussão para interagir além do que foi solicitado. A formalidade mista, presente em boa parte dos momentos de saudação e despedida, pode representar uma tendência à informalidade, porém ainda presa a práticas tradicionais. 
Os questionamentos também fazem parte da interação, principalmente quando não se limitam à função retórica, pois buscam no grupo a construção colaborativa de algum conceito ou definição. Rabello (2011) vê, na concepção sociointeracionista de Vygotsky, aplicação às possibilidades ofertadas pela internet, apontando para um aprendiz integrante, de fato, de um grupo social, pois possui "iniciativa para questionar, descobrir e compreender o mundo a partir de interações" (op. cit., p. 27). Esses questionamentos podem ser diretos ("E como seria essa transformação professora [nome da professora]?") ou sutis (Companheiro, [...] será que um dia serei uma nativa digital?"), mas, independente da abordagem, representam uma tentativa de estabelecer um diálogo mais aprofundado acerca do assunto tratado.

Quanto aos recursos linguísticos, observou-se pouca utilização para atribuir sentido extra às postagens, porém ainda foi possível encontrar textos em cores diversas, imagens, hiperlinks, aspas em palavras-chaves (nativos e imigrantes digitais, principalmente), arquivos de texto anexados, todas as palavras da mensagem em letras maiúsculas, excesso de parágrafos e de pontuação, palavras sublinhadas e em itálico e demonstração de risada pela repetição de letras ("kkk"). 


\title{
Exemplo de mensagem com hiperlink, excesso de pontuação e aspas
}

Re: Atividade da Terceira Semana por

\author{
domingo, 18 agosto 2013, 18:10
}

Os nativos digitais apreendem como comprar algo, baixar músicas, filmes, etc, de uma forma muito rápida, como também a fazer uma série de coisas, mas deixa muito a desejar na hora de usar em prol da educação formal. No dia a dia em sala de aula, nós professores, "lutamos" para que as TICs tenha seu lugar, não é toda hora e nem em toda aula, pois nossos alunos precisam saber escrever segundo o padrão, não dá pra ficar só na net, acredito eu, que a net é muito importante para a aquisição de saberes nesta pós-modernidade, mas outros saberes se faz necessário para a formação humanística do Homem. Pois se não for assim, nossos jovens em um futuro bem próximo terão uma enorme dificuldade de grafar as palavras, de se relacionarem de forma real, pois as coisas tendem a ser tudo virtual: amizades, namoros, encontros,etc. Imagine se nós não impormos os limites do uso da net na salc

de aula????... O que será do código escrito, dos valores, da moral, etc. ......... O porvir é muito tenebroso neste sentido.

\section{Exemplo de mensagem com formatações textuais, aspas e palavras em maiúsculo}

\section{Re: MARIA}

por
- segunda, 26 agosto 2013, 17:10

"A educação está passando pelo um grande desafio,diante desse novo método pedagógico que é a chegada dos Tablets nas escolas. E temos que aderir a essa inovação tecnológica ou ficamos para traz."

Prezada colega,

Os meios tecnológicos digitais assumem uma substituição das máquinas de escrever, dos mimeógrafos, dos projetores ou retroprojetores entre outros meios copiados para a EDUCAÇÃO, mas que foram criados para uso militar.

Nesse sentido, tais equipamentos vieram substituir esses multimeios citados. Na verdade, os MÉTODOS PEDAGÓGICOS perpassam ou vão além de meios tecnológicos - pontuam o ensino aprendizagem a partir dos Direitos de Aprendizagem dos alunos - pois a leitura/escrita, a escrita/leitura, análises, palestras, debates, conferências, estudo de campo, entre outros, delimitados no currículo não representa necessariamente a imposição do uso desses equipamentos.

Na escola onde leciono, o laboratório de informática existe, mas o sinal da web é insuficiente para as máquinas funcionarem na teia. Assim como, os tablets, também, não entram em cena, pois a INTERNET oferece péssima qualidade no sinal - uma derrocada da tecnologia.

Não somos obrigadas/os a preparar um plano de aula com tais ferramentas, apenas para satisfazer o interesse de terceiros.

Acalme-se e continue exercendo o seu labor de ensino aprendizagem da forma mais natural, real e acima de tudo didática com sabor e saber.

Muito sucesso na caminhada!

Saudações didáticas,

[nome da aluna]

Mostrar principal | Editar | Interromper | Excluir | Responder

\section{Neste último exemplo, pode ser encontrada uma refe- rência à Netiqueta, quando na regra para fóruns e grupos de discussões "Colocar o texto acima da resposta". Neste}


caso, segundo Madalena (2013), torna-se mais fácil apresentar-se num diálogo organizado em ordem cronológica, além de reforçar a identificação sobre a mensagem referenciada.

Um último ponto interessante a ser relatado é a emissão de opiniões acerca do tema abordado neste trabalho. Estas colocações representam um rico celeiro de assuntos a serem abordados e discutidos entre os alunos e mediados pelo professor responsável. São opiniões que transitam entre os grupos, fora do ambiente virtual, e que podem, aqui, fazerem-se representadas, aumentando a rede de saberes de todos os envolvidos.

Comentários sobre Interação e Linguagem no fórum da Turma 5

\begin{tabular}{|c|l|}
\hline \multicolumn{2}{|c|}{ Comentários sobre Interação e Linguagem } \\
\hline A & $\begin{array}{l}\text { "A linguagem é o alicerce da cultura humana, sendo instrumento } \\
\text { de sua manifestação e desenvolvimento." }\end{array}$ \\
\hline B & $\begin{array}{l}\text { "A linguagem é uma forma ou processo de interação, é um } \\
\text { instrumento para própria cultura." }\end{array}$ \\
\hline C & $\begin{array}{l}\text { "A linguagem é uma forma de nos comunicar, assumindo um } \\
\text { papel importante de conhecer nossos valores e costume de nossa } \\
\text { cultura como também de nossa sociedade." }\end{array}$ \\
\hline D & $\begin{array}{l}\text { "Devemos nos adaptarmos as novas linguagens tecnológicas } \\
\text { para facilitar a aprendizagem dos nossos alunos a fim de } \\
\text { despertar a necessidade de compartilhar conhecimentos } \\
\text { significativos através de pesquisas, jogos educativos, projetos } \\
\text { garantindo a necessidade de juntos trocarmos experiências e nos } \\
\text { colocarmos na condição de aprendizes pois temos o domínio } \\
\text { dos conteúdos. Mas que linguagem iremos utilizar para que essa } \\
\text { comunicação se efetive de forma clara e objetiva?" }\end{array}$ \\
\hline E & $\begin{array}{l}\text { "Os nativos digitais digitais não querem ser apenas meros } \\
\text { espectadores, eles sentem a necessidade de serem atores. } \\
\text { Esperam, querem e precisam de comunicação interativa." }\end{array}$ \\
\hline
\end{tabular}


Visões interessantes e, de certa forma, criativas, foram encontradas, como no seguinte comentário: "Para o grupo dos nativos digitais (Geração Y e Z) e imigrantes digitais (Geração X), poderia ser formado um novo 'Plano cartesiano', em que a 'reta' x (Geração X) e 'reta' y (Geração Y e Z) poderiam se 'unir', formando uma reta dupla, imaginária e crescente, e todos pudessem superar os desafios e atingissem o sucesso.". O que o aluno descreveu (ilustrado abaixo) corrobora com Prensky (2001) $)^{8}$, quando defende imigrantes e nativos digitais dotados de formas diferentes de processar uma informação, mas que, com objetivo compartilhado e união de habilidades individuais, torna-se natural o processo integrador entre os sujeitos e seus saberes adquiridos.

\section{Novo plano cartesiano (proposto por aluno)}

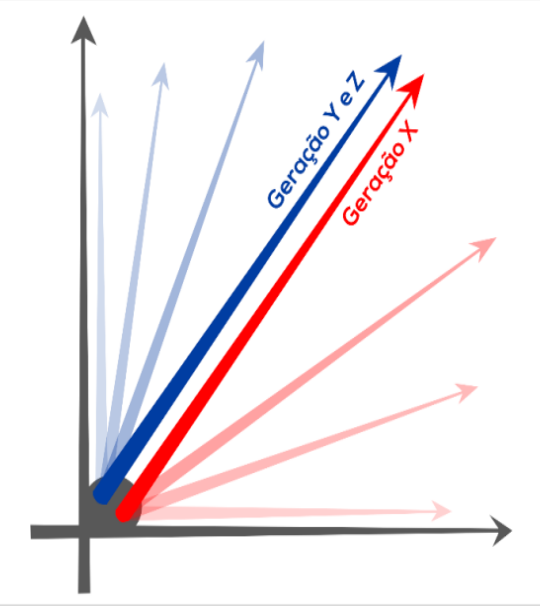

8 http://www.emeraldinsight.com/doi/pdfplus/10.1108/1074 8120110424816 
Em geral, o fórum apresentou um nível de interação pessoal considerável, apesar de, segundo Kearsley (2011), não ser uma necessidade primária para estudantes de pós-graduação. Quanto à linguagem utilizada, os participantes exploraram um pouco os recursos ofertados pelo Moodle, além do próprio texto e suas variações, o que é compreensível, por ser este um público aprendiz das tecnologias digitais. Vale salientar que, apesar disto, houve discussão e exposição das opiniões a favor da congruência de saberes entre nativos e imigrantes digitais, configurando, portanto, uma aprovação dos recursos digitais utilizados nos processos educacionais institucionalizados.

\section{Chegando ao destino}

O potencial existente no processo de interação em rede virtual, muito além da real, está nas possibilidades de representação da informação em formatos e suportes distintos, que, combinados, permitem ricas interpretações semânticas e aprendizagens significativas. Para isso, os interagentes precisam partilhar objetivos, linguagem e conhecimentos prévios, a fim de tornar a comunicação satisfatória para os envolvidos.

Os fóruns analisados reuniram professores em formação continuada (naquele momento, alunos) com o objetivo de interagir, respondendo a atividade avaliativa solicitada. $\mathrm{O}$ espaço utilizado abrigava recursos digitais e de formatação, que permitiriam um acréscimo semântico substancial ao conteúdo textual. A tímida exploração desses recursos, no entanto, pode ser justificada pelo desconhecimento da ferramenta e de suas possibilidades de uso. 
No que tange ao conteúdo das postagens, percebeu-se que a temática da semana (nativos versus imigrantes digitais) foi compreendida pelos participantes, tendo, porém, pouca variação de teor conceitual nas contribuições. É possível que a solicitação de uma frase reflexiva, com limite de duas linhas, tenha conduzido as respostas a uma mesma linha de pensamento, com base nas referências disponibilizadas anteriormente. Apesar disto, houve, também, relatos de professores que se identificaram como nativos ou imigrantes digitais, e perceberam, diante de sua práxis, a importância de discutir e de praticar as possibilidades ofertadas pelos recursos digitais.

A partir das mensagens trocadas, foram identificadas e categorizadas situações de análise do diálogo (a seguir), indicando um nível relativamente baixo de engajamento ao grupo, pois a ocorrência de mensagens apenas com a frase solicitada foi considerada superior à disposição de elementos interacionais.

- Categoria "Saudação Inicial": chamamento formal, informal, misto, informal e por turno, afetivo, informal nominal, temático, incentivo e congratulações e por turno;

- Categoria "Interação": questionamento retórico, direto, concordância ou discordância direta (nominal), agradecimento direto (não nomeado), resposta direta ao mediador, incentivo nominal e à equipe;

- Categoria "Encerramento da Mensagem": nome da pessoa, simbologia, despedida formal ao grupo, informal, intensa, composta, virtual e assinatura informativa. 
A característica mista (b-learning) do curso de PósGraduação analisado deveria proporcionar aos participantes uma representação maior da afeição construída, já que houve oportunidade de encontros presenciais, além da possibilidade de vínculos pré-existentes. No entanto, as poucas interações entre os participantes revelaram uma presença social pouco marcante, sendo esta uma questão importante a ser aprofundada em pesquisas futuras.

O professor mediador, num cenário carente de envolvimento afetivo e de contribuições inovadoras, tem a função de encorajar, reconhecer e contribuir com as postagens dos alunos, em função do que lhe é possível ter de informação (perfil e participações). Apesar da distância física - o que, neste caso, pode não ter sido total, já que houve a possibilidade de que os alunos conhecessem pessoalmente também seus professores mediadores -, estes profissionais precisam construir um ambiente envolvente e rico em feedbacks, para que o grupo e os indivíduos sintam que suas colocações estão sendo percebidas e reconhecidas.

Estas observações apontam para questões discutidas, antes de tudo, no ensino presencial, quando o diálogo é controlado por alguns poucos indivíduos. A interação em ambientes virtuais de aprendizagem, assim como a exposição dos conteúdos e o planejamento do curso e das aulas, por exemplo, tendem a repetir as dinâmicas escolares em ambientes físicos, porém inexistem elementos equivalentes o suficiente para firmar qualitativamente as transferências conceituais. É necessário adequar, nos dois ambientes, os recursos disponíveis à proposta, considerando, principalmente, os mesmos três itens, que devem ser partilhados em uma interação: o objetivo, a linguagem 
e os conhecimentos prévios do grupo. A partir disto, será possível ampliar o potencial nato do ser humano de compartilhar saberes e construir significados integrados às múltiplas formas de representação da informação.

\section{Referências}

ALVES, Aglaé Cecília Toledo Porto. EaD e a formação de professores. In: VALENTE, José Armando; ALMEIDA, Maria Elizabeth Bianconcini de (orgs.). Formação de educadores a distância e integração de mídias. São Paulo: Avercamp, 2007.

AMARAL, Adriana. Etnografia e pesquisa em cibercultura: limites e insuficiências metodológicas. In: REVISTA USP, São Paulo, n.86, p. 122-135, junho/agosto 2010. Disponível em <http://www.revistas.usp.br/revusp/ article/view/13818> Acesso em 29 de junho de 2014.

AMARAL, Adriana; NATAL, Geórgia; VIANA, Lucina. Netnografia como aporte metodológico da pesquisa em comunicação digital. In: Sessões do Imaginário, vol.13(20), 34-40, 2008. Disponível em < http://revistaseletronicas.pucrs.br/ojs/index.php/famecos/article/ download/4829/3687 > Acesso em 05 de julho de 2014.

ANDRE, Marli Eliza Dalmazo Afonso de. Etnografia da prática escolar. 14 ed. Campinas-SP: Papirus, 2008.

BOLZAN, Doris Pires Vargas; ISAIA, Silvia Maria de Aguiar. Pedagogia universitária e aprendizagem docente: relações e novos sentidos da professoralidade. In: Revista 
Diálogo Educacional, Curitiba, v. 10, n. 29, p. 13-26, 2010. Disponível em http://www2.pucpr.br/reol/index.php/ DIALOGO?dd1=3422\&dd99=pdf. Acessado em 14 de outubro de 2012.

BRAGA, Denise Bértoli. Ambientes virtuais: reflexões teóricas e práticas. São Paulo: Cortez, 2013.

CRYSTAL, David. A revolução da linguagem. Rio de Janeiro: Jorge Zahar Ed., 2005

FÁVERO, Leonor Lopes et al. Interação em diferentes contextos. In: BENTES, Anna Christina; LEITE, Marli Quadros. Linguística de texto e análise da conversação: panorama das pesquisas no Brasil. São Paulo: Cortez, 2010.

FILATRO, Andrea. Design instrucional contextualizado: educação e tecnologia. 3 ed. São Paulo: Editora Senac São Paulo, 2010.

GUMPERZ, John Joseph. Convenções de contextualização. In: RIBEIRO, Branca Telles; GARCEZ, Pedro M. (orgs.). Sociolinguística interacional. São Paulo: Editoras Loyola, 2002.

KEARSLEY, Greg. Educação on-line: aprendendo e ensinando. São Paulo: Cengage Learning, 2011.

KERCKHOFF, Marcia Telesca. A atuação e o discurso do professor na tutoria online no ensino superior. Tese de doutorado. (Programa Interdisciplinar de Pós-Graduação em Linguística Aplicada), Universidade Federal do Rio 
de Janeiro, Rio de Janeiro, 2014. Disponível em < http:/ / www.letras.ufrj.br/linguisticaaplicada/site/teses/ 2014-marciatelesca.pdf $>$. Acesso em 09 de outubro de 2015.

$\mathrm{KOCH}$, Ingedore. A inter-ação pela linguagem. 10 ed. São Paulo: Contexto, 2006.

KOZINETS, Robert. Netnografia: realizando pesquisa etnográfica online. Porto Alegre: Penso, 2014.

MADALENA, Emanuel Verdade da. Netiqueta - as regras sociais de comportamento e comunicação na internet. Dissertação de mestrado $\left(2^{\circ}\right.$ Ciclo de Estudos em Ciências da Comunicação - Estudos de Média e Jornalismo), Faculdade de Letras - Universidade do Porto, Portugal, 2013. Disponível em < https://sigarra.up.pt/flup/pt/ publs_pesquisa.FormView?p_id=72155 >. Acesso em 20 de dezembro de 2015.

MARCUSCHI, Luiz Antônio. Da fala para a escrita: atividades de retextualização. São Paulo: Cortez, 2001.

MOITA, Filomena. Game on: jogos eletrônicos na escola e na vida da geração @. Campinas-SP: Editora Alínea, 2007.

MOORE, Michael; KEARSLEY, Greg. Educação a distância: uma visão integrada. São Paulo: Thomson Learning, 2007.

MORAN, José Manuel. A educação que desejamos: novos desafios e como chegar lá. Campinas-SP: Papirus, 2007. 
OLIVEIRA, Daniela Motta de. Políticas de formação continuada de professores. In: OLIVEIRA, Daniela Motta de. Formação continuada de professores: contribuições para o debate. Juiz de Fora: Editora UFJF, 2012.

PALLOFF, Rena M.; PRATT, Keith. O instrutor online: estratégias para a excelência profissional. Porto Alegre: Penso, 2013.

PETERS, Otto. Didática do ensino a distância: experiências e estágio da discussão numa visão internacional. São Leopoldo-RS: Editora UNISINOS, 2006.

PRADO, Maria Elisabette Brisola Brito; ALMEIDA, Maria Elizabeth Bianconcini de. Estratégias em educação a distância: a plasticidade na prática pedagógica do professor. In: VALENTE, José Armando; ALMEIDA, Maria Elizabeth Bianconcini de (orgs.). Formação de educadores a distância e integração de mídias. São Paulo: Avercamp, 2007.

RABELLO, Márcia Rodrigues. Interações sociais no ambiente virtual de aprendizagem: análise da linguagem de feedbacks. Dissertação de mestrado (Mestrado em Educação), Universidade Passo Fundo, Rio Grande do Sul, 2011.

ROCHA, Paula Jung; MONTARDO, Sandra Portella. Netnografia: incursões metodológicas na cibercultura. In: E-compós - Revista da Associação Nacional dos Programas de Pós-Graduação em Comunicação, dez, 2005. Disponível em < http://compos.org.br/seer/index. 
php/e-compos/article/viewFile/55/55 > Acesso em 20 de fevereiro de 2015.

SHEPHERD, Tania Granja; SALIÉS, Tania Gastão. Linguística da internet. São Paulo: Contexto, 2013.

SILVA, Ivanderson Pereira da; LESSA, Rose Karla Cordeiro; MERCADO, Luís Paulo Leopoldo. Mediação pedagógica em fóruns de discussão no contexto da experiência do estágio de docência online. In: Revista EDaPECI São Cristóvão (SE), v.15. n. 1, p. 30-56, jan. /abr. 2015. Disponível em <http://www.seer.ufs.br/index.php/ edapeci/article/view/3076/pdf>. Acesso em 07 de outubro de 2015. 



\title{
EDUCOMUNICAÇÃO NO ESPAÇO \\ DA EDUCAÇÃO FORMAL: atividades interdisciplinares
}

\author{
Lígia Beatriz Carvalho de Almeida ${ }^{1}$ \\ Roseane Andrelo ${ }^{2}$ \\ Mariana Pícaro Cerigatto
}

\section{O estudo da mídia no ensino médio}

Há muito questionamento sobre a propriedade de se estudar a mídia na educação formal, como preconiza a educomunicação. Com a finalidade de responder a esses questionamentos, realizou-se um levantamento de argumentos nas normativas e diretrizes que regulamentam a educação formal em nosso país e que justificam o desenvolvimento de propostas como a que se apresenta neste trabalho.

1 Pedagoga e radialista, mestre em comunicação midiática e doutora em educação. É professora no curso de Comunicação Social com linha de formação em Educomunicação da Universidade Federal de Campina Grande. Líder do grupo de pesquisa EpisCom na UFCG. E-mail: ligiabia@gmail.com.

2 Jornalista, mestre em comunicação midiática e doutora em educação escolar. Professora da Pós-Graduação em Comunicação e do curso de Comunicação Social da Unesp. E-mail: roseane. andrelo@faac.unesp.br.

3 Jornalista, mestre em TV Digital e doutora pela Universidade Estadual Paulista (Unesp). Integrante do grupo de pesquisa EpisCom. E-mail: maricerigatto@yahoo.com.br. 
Habitualmente, conforme destaca Soares (2004), o uso das tecnologias em ambiente escolar no Brasil envolve três principais frentes de atuação: a) o uso instrumental das tecnologias na educação para o ensino-aprendizagem de conteúdos curriculares, conhecido como mídia educativa (ou tecnologia educacional); b) o uso da tecnologia para ensinar a distância, denominado de EaD; c) a educação para a mídia, que se centra no ensino e aprendizagem para o uso da comunicação mediada por tecnologias e sobre a atuação dos meios de comunicação na sociedade.

A Constituição Federal aponta como competência da União e dos Estados a de legislar sobre a educação, a cultura e o ensino. No artigo 205, destaca que a educação é dever do Estado e da família com o objetivo de promover o "pleno desenvolvimento da pessoa, seu preparo para o exercício da cidadania e sua qualificação para o trabalho". Entre os princípios da educação figura "a liberdade de divulgar o pensamento" (BRASIL, 1988). Também o item IX, do Capítulo I, Título II assevera a liberdade de comunicação, ao tratar dos direitos e deveres individuais e coletivos. No Capítulo V, a carta magna brasileira traz uma série de deliberações acerca da comunicação social. Afirma, no artigo 220, que a manifestação do pensamento, sob qualquer forma, não sofrerá qualquer restrição. A leitura desses trechos permite concluir sobre a liberdade que os brasileiros devem ter para expressar seu pensamento, competência a ser desenvolvida com o incentivo à prática da comunicação.

A Lei de Diretrizes e Bases, ao tratar da educação escolar, como não poderia deixar de ser, expressa o mesmo objetivo que a Constituição. De acordo com o artigo primeiro (BRASIL, 1996) “A educação abrange os processos formativos que se desenvolvem na vida familiar, na convivência 
humana, no trabalho, nas instituições de ensino e pesquisa, nos movimentos sociais e organizações da sociedade civil e nas manifestações culturais". A seção segunda declara que "A educação escolar deverá vincular-se ao mundo do trabalho e à prática social". Tais proposições autorizam uma intersecção com as funções que a comunicação social ocupa na organização da visão de mundo e das práticas sociais dos indivíduos. Ela tem ainda papel coadjuvante na formação da vida familiar, transmite e promove várias formas de manifestação cultural.

O artigo 32 da LDB, apesar de não mencionar diretamente os meios de comunicação, refere-se à face instrumental da tecnologia como objeto da formação básica do cidadão: "a compreensão do ambiente natural e social, do sistema político, da tecnologia, das artes e dos valores em que se fundamenta a sociedade" (BRASIL, 1996).

Tratando especificamente das finalidades do ensino médio, no artigo 35, a LDB destaca:

I - a consolidação e o aprofundamento dos conhecimentos adquiridos no ensino fundamental, possibilitando o prosseguimento de estudos;

II - a preparação básica para o trabalho e a cidadania do educando, para continuar aprendendo, de modo a ser capaz de se adaptar com flexibilidade a novas condições de ocupação ou aperfeiçoamento posteriores;

III - o aprimoramento do educando como pessoa humana, incluindo a formação ética e o desenvolvimento da 
autonomia intelectual e do pensamento crítico;

IV - a compreensão dos fundamentos científico-tecnológicos dos processos produtivos, relacionando a teoria com a prática, no ensino de cada disciplina.

$\mathrm{O}$ artigo 35-A fornece as diretrizes que devem ser observadas no currículo do ensino médio:

$\S 8^{\circ}$ Os conteúdos, as metodologias e as formas de avaliação serão organiza-dos de tal forma que ao final do ensino médio o educando demonstre:

I - domínio dos princípios científicos e tecnológicos que presidem a produção moderna;

II - conhecimento das formas contemporâneas de linguagem;

Nesses artigos trata-se de: cidadania, formação da pessoa humana, desenvolvimento da intelectualidade e da criticidade, fundamentos tecnológicos dos processos produtivos, compreensão de significados e de processos históricos, sociais e culturais, da língua materna, do acesso ao conhecimento, exercício da cidadania, novas metodologias de ensino motivadoras. Configuram-se esses como campos que podem acolher a educação para a mídia, por ter como um de seus principais objetivos o desenvolvimento da criticidade. Além de ser determinante para a efetivação de diálogos interculturais, a participação na mídia tem sido considerada um pré-requisito 
para o exercício da liberdade de expressão e do direito à informação, condições fundamentais para a construção e manutenção da cidadania ativa e da democracia participativa (EUROPEAN COMISSION, 2007).

Entre as competências, que o Estado deseja ver desenvolvidas pelas crianças e jovens brasileiros, destacadas na Base Nacional Comum Curricular (MEC, 2017) e que mantêm relação com a cultura midiática e a educomunicação estão: a) valorizar conhecimentos sobre a cultura e o mundo digital para entendê-los, continuar aprendendo e colaborar na construção da sociedade; b) valorizar, fruir e protagonizar manifestações artísticas e culturais; c) Expressar-se e compartilhar informações por diferentes linguagens - verbal, corporal, visual, artística, sonora e digital para alcançar entendimento mútuo;

5. Compreender, utilizar e criar tecnologias digitais de informação e comunicação de forma crítica, significativa, reflexiva e ética nas diversas práticas sociais (incluindo as escolares) para se comunicar, acessar e disseminar informações, produzir conhecimentos, resolver problemas e exercer protagonismo e autoria na vida pessoal e coletiva; [...]

9. Exercitar o diálogo, a resolução de conflitos e a cooperação, fazendo-se respeitar e promovendo o respeito ao outro e aos direitos humanos, com acolhimento e valorização da diversidade de indivíduos e de grupos sociais, seus saberes, identidades, 
culturas e potencialidades, sem preconceitos de qualquer natureza;

10. Agir pessoal e coletivamente com autonomia, responsabilidade, flexibilidade, resiliência e determinação, tomando decisões com base em princípios éticos, democráticos, inclusivos, sustentáveis e solidários (MEC, 2017, pp. 9-10)

Os Parâmetros Curriculares Nacionais (PCNs) do Novo Ensino Médio ${ }^{4}$ também se aproximam dos pressupostos da educomunicação quando se propõem a "preparar [os estudantes] para a vida, qualificar para a cidadania e capacitar para o aprendizado permanente"; "saber se informar, comunicar-se, argumentar, compreender e agir [...] participar socialmente, de forma prática e solidária" (MEC, 2018, p. 9-10).

Conforme indicado pela Secretaria de Educação Básica do Ministério da Educação brasileiro, os PCN's do ensino médio deverão ser organizados nas seguintes áreas de conhecimento: Linguagens, códigos e suas tecnologias; Ciências da Natureza, Matemática e suas tecnologias; Ciências Humanas e suas tecnologias. A área das Linguagens, Códigos e suas Tecnologias pretende que o estudante seja capaz de "distinguir realidade de construção simbólica do real, recuperar as formas instituídas de

4 Devem ser implantados a partir de 2019, conforme orientações governamentais disponíveis em http://www2.planalto.gov. br/acompanhe-planalto/noticias/2017/12/entenda-o-que-muda-com-a-nova-base-nacional-comum-curricular. Acesso em: 25 maio 2018. 
construção do imaginário coletivo, dominar os componentes estruturais das diversas linguagens e seus arranjos possíveis, compreender criticamente a diversidade das linguagens" (MEC, 2018, p. 27).

Para atingir as competências e habilidades relacionadas no eixo Conceitos, que se encarrega de "propiciar condições para que o aluno encare o conhecimento como instrumento para entender e analisar a realidade cotidiana e refletir sobre ela" (MEC, 2018, p. 46), espera-se que o estudante esteja apto a:

1. Analisar e interpretar no contexto de interlocução.

2. Reconhecer recursos expressivos das linguagens.

3. Identificar manifestações culturais no eixo temporal, reconhecendo momentos de tradição e de ruptura.

4. Emitir juízo crítico sobre essas manifestações.

5. Identificar-se como usuário e interlocutor de linguagens que estruturam uma identidade cultural própria. 6. Analisar metalinguisticamente as diversas linguagens (MEC, 2018, p. 46).

Neste eixo, faz-se menção direta à leitura crítica da mídia:

Impossível não trazer para a escola a linguagem da televisão como objeto de estudo, assim como as linguagens 
que usam o computador como suporte. A compreensão dos processos empregados na mídia e na internet é uma competência exigida para a preparação do cidadão crítico da atualidade. Trabalhos de "tradução" intersemiótica (poema para quadro; quadro para poema; texto narrativo para filme....) podem auxiliar na aquisição e no desenvolvimento dessa competência analítica (MEC, 2018, p. 46).

A mídia também é mencionada quando se indica formas de aprendizagem do conceito redundância (MEC, 2018, p. 48):

Que nível de redundância a mídia incorpora em seus produtos a fim de garantir o consumo planejado pela economia? Que nível de informação a indústria do entretenimento suporta sem colocar em risco grandes capitais? Que níveis de redundância transformam a moda das elites em produto assimilável pelas camadas ditas populares?

Igualmente sugere-se o trabalho com a mídia em outros locais do documento, como o uso do rádio e da televisão para diferenciar informação de redundância; ao tratar da dicotomia global-local; para ampliar o desenvolvimento vocabular, recorrendo às notícias e à propaganda; 
correlacionar a representação do esporte com espetáculo e consumo na mídia, destinados à moldar o imaginário social; na apropriação dos meios e tecnologias, vídeo e cinema ao trabalhar com as artes ou em projetos culturais artísticos hipermidiáticos.

É, no entanto, ao abordar a Informática, que o documento oficial abre-se à perspectiva de valor para o campo educomunicacional: a do diálogo, ao afirmar:

A possibilidade de estar em contato frequente com pessoas de diferentes localidades potencializa a troca de ideias e experiências na busca dos melhores caminhos para promover o ensino e a educação, além de permitir que todos os que fazem parte daquela comunidade mantenham-se informados: diariamente circulam informações sobre educação veiculadas na mídia eletrônica ou impressa, além de referências a congressos, seminários e cursos na área educacional (MEC, 2018, p. 232).

Reconhece-se a centralidade das tecnologias de informação e comunicação e da cultura tecnológica na vida dos estudantes e na educação, não só sob a perspectiva de leitura de textos, mas também da produção de textos, revelando a ambição de formar um cidadão protagonista, criador: "As novas tecnologias de informação e comunicação apresentam-se como elementos que promovem e incentivam modificações significativas na educação básica", permitindo ao aluno "apresentar 
suas ideias de forma clara e coerente para uma plateia mais ampla de interlocutores, seja através dos meios de comunicação existentes na internet, seja pela publicação de material na rede" (MEC, 2018, pp. 219-220). Admite-se o seu valor para o ingresso no mercado de trabalho:

A tecnologia é o tema por excelên-
cia que permite contextualizar os
conhecimentos de todas as áreas e
disciplinas do mundo do trabalho
[...] É imprescindível, nesse contexto,
estimular o indivíduo a usufruir
dos recursos apresentados por uma
sociedade científico-tecnológica,
bem como prepará-lo para o mer-
cado de trabalho (MEC, 2018, p. 220).

Os argumentos aqui compilados não reúnem todos aqueles presentes nas normativas que regulamentam a educação no Brasil, são entretanto suficientes para demonstrar a pertinência de se abordar a cultura midiática na escola, norteados pela perspectiva da educomunicação.

\section{Educomunicação}

O neologismo educomunicação resulta da união das palavras educação e comunicação e foi proposto na década de 1980 pela UNESCO e por Mario Kaplún (SOARES, 2008, p.43). A Educomunicação tem como objeto de estudo os saberes alocados na intersecção dos campos da educação e da comunicação. O novo campo de conhecimento 
tem identidade própria, porém incorpora muito dos dois outros campos. Sua legitimação veio como resultado do trabalho de pesquisadores na América Latina, entre eles, com expressiva atuação, figura o pesquisador brasileiro Ismar de Oliveira Soares, filiado ao Núcleo de Comunicação e Educação da Escola de Comunicações e Artes, na Universidade de São Paulo.

Trata-se de um conceito amplo que prevê atividades educomunicativas em diversos espaços sociais, não apenas na educação formal e tampouco envolvendo somente crianças e jovens. Pode-se considerar que sua força motriz é a vivência democrática plena, vivência esta diretamente dependente da compreensão e aceitação por parte da população dos direitos e deveres que regulam a vida em sociedade. Vale lembrar que muitos dos direitos assegurados por atos normativos, não são plenamente exercidos por falta de empoderamento social, uma vez que os cidadãos contemporâneos são frutos de um longo processo sócio histórico de negação dos mesmos, durante o qual arcaicas estruturas de poder foram internalizadas e naturalizadas pelas pessoas, dificultando a ruptura da ordem hegemônica.

Assim, a educomunicação, em atividades de intervenção que têm como foco a educação para a comunicação, busca habilitar os cidadãos a exercerem seus direitos, principalmente aqueles que envolvem o acesso à informação e a liberdade de expressão. O educomunicador trabalha para conscientizar as comunidades sobre o seu papel na sociedade, sobre a relevância da comunicação social e sobre as responsabilidades envolvidas no exercício desses direitos. 
Ressalta-se, contudo que para usufruir plenamente desses direitos, é preciso prover formação educativa que possa munir os indivíduos com competências consideradas essenciais aos atos de: expressar-se, acessar e selecionar informações relevantes e significativas. É essencial saber pesquisar e interpretar dados, já que as informações úteis são aquelas que acabam por se transformar em conhecimento. Essas habilidades e competências precisam ser desenvolvidas e exercitadas ao longo da vida e a escola, que é um relevante microcosmo social em que se convive por significante período de tempo, figura como o lócus privilegiado para consolidá-las.

É nesse sentido que a educomunicação dialoga com a educação e a comunicação, envolvendo cidadãos, educadores e comunicadores em atividades que podem ser praticadas em ambientes de educação formal e não-formal, associações comunitárias, instituições públicas, privadas ou do terceiro setor. Em um país democrático, como o Brasil, onde quer que exista a necessidade ou a oportunidade de diálogo, haverá espaço para atividades educomunicativas. Neste texto, contudo, o foco incidirá sobre práticas a serem desenvolvidas no interior das escolas de educação básica, apresentando-se uma sugestão metodológica de atividade interdisciplinar para a leitura de textos midiáticos em sala de aula.

\section{A Educomunicação na Educação Formal}

A educomunicação contribui com as atividades educativas com o objetivo de planejar, implantar e avaliar práticas que privilegiem a construção coletiva de conhecimento, 
alicerçadas pela pesquisa e pelo diálogo horizontalizado e, quando necessário, ampliadas com o auxílio das TICs.

Soares aborda essa relação e define a educomunicação como um conjunto de ações direcionadas a planejar, implantar e avaliar procedimentos destinados à:

criar e a fortalecer "ecossistemas comunicativos", qualificados como abertos e participativos, garantidos por uma gestão democrática dos processos de comunicação nos diferentes ambientes de relacionamento humano (envolvendo, no caso, em igualdade de condições, a comunidade como um todo, seja ela educativa ou comunicativa); ampliar o potencial comunicativo e as condições de expressividade dos indivíduos e grupos humanos, mediante práticas culturais e artísticas, assim como através do uso dos recursos disponibilizados pela era da informação, tendo como meta prioritária o reconhecimento do protagonismo infantojuvenil; favorecer referenciais e metodologias que permitam às comunidades humanas relacionarem-se, enquanto sujeitos sociais, com o sistema midiático (SOARES, 2014b, p. 17).

Da fala de Soares, depreende-se a preocupação com a ampla circulação de ideias na sociedade e que envolve: a) o diálogo e para promovê-lo, no sentido da construção de 
conhecimento, a utilização das tecnologias da informação e da comunicação nos espaços educativos; b) a conscientização e o empoderamento dos cidadãos para que exerçam o seu direito à fala; c) as mensagens midiáticas, que irrigam o tecido social impactando a sociedade.

Tratando especificamente do ambiente escolar, o pesquisador, em entrevista à Bizoni (2005) do jornal Folha Dirigida, esclarece que as ações educomunicativas podem colaborar para a solução de problemas de diferentes ordens encontrados no cotidiano das comunidades escolares:

Alguém diz: meu problema é a violência na escola, meu problema é falta de aprendizado na área das Ciências Exatas, meu problema é a rejeição que grupos de alunos têm com outros grupos, ou com os professores. Seja qual for o problema, haverá uma solução educomunicativa, que tem como meta criar ecossistemas comunicativos abertos, dialógicos, participativos, através de uma gestão democrática dos recursos, através de uma aplicação de conhecimentos sobre como manejá-los. Esse conjunto de atividades nós chamamos de Educomunicação (SOARES apud BIZONI, 2005).

O conceito de ecossistema é central à educomunicação e requer conceituação. Sua origem remonta à ecologia, com o significado de "conjunto das relações de interdependência, reguladas por condições físicas, químicas e biológicas, 
que os seres vivos estabelecem entre si e também com o meio ambiente em que habitam" (PRIBERAM, 2014). No universo da comunicação, remete aos processos que permitem a interação entre os elementos de uma comunidade, ou entre diversas comunidades e destas com o meio circundante, já que existe uma dependência entre os diversos ecossistemas comunicativos que se interinfluenciam. Nas escolas, segundo Soares (apud SALVATIERRA, 2014), ecossistemas comunicativos indicam ambientes em que "professores, funcionários, alunos, pais ou responsáveis, sentam, dialogam e discutem os problemas da escola, da comunidade ou mesmo do Estado, de forma franca e aberta, usando os recursos tecnológicos sempre que possível para potencializar relações".

Zelar para que os ecossistemas comunicativos sejam abertos e dialógicos é a função da educomunicação. Para tanto, é preciso conhecer como os grupos se organizam na escola, saber quais valores, coletivamente pactuados, regem as formas de pensar, agir e sentir de seus componentes, reafirmando aqueles considerados adequados e substituindo, ou descartando, os que obstruam os fluxos de comunicação por serem afiliados a esquemas de opressão. Assim, se estará deflagrando um processo de ajuste da escola às aspirações das sociedades democráticas (SALVATIERRA, 2016a).

A educomunicação prevê ações alocadas didaticamente em sete diferentes áreas de intervenção (SOARES, 2014), que atendem dificuldades específicas do sistema escolar, sendo expostas a seguir. 


\section{Educação para a comunicação}

Pretende-se desenvolver a consciência crítica frente às mensagens midiáticas uma vez que: com grande frequência, a aula é invadida por assuntos propostos pelos meios de comunicação; o conceito de cultura e arte é, em grande parte, moldado por eles; o comportamento das crianças reproduz padrões disseminados nos meios de comunicação social; os conhecimentos adquiridos através da mídia nem sempre condizem com a realidade, muito menos, se considerarmos a realidade local. Neste sentido, há a compreensão de que os conteúdos midiáticos se configuram como importantes componentes culturais e artísticos, necessitando ser analisados em sala de aula, tamanha a dimensão que a mídia ocupa nos processos sociais. Para levar os estudantes a compreenderem os processos midiáticos são desenvolvidas tanto atividades de leitura crítica da mídia quanto de produção de mídia (SOARES, 2014);

\section{Pedagogia da comunicação}

Propõe estratégias visando à implantação e à manutenção de bons fluxos de diálogo que permitam a interação entre os elementos de um grupo, tão necessários à aprendizagem, como ressalta Paulo Freire (2002, p. 69): “a educação é comunicação, é diálogo, na medida em que não é transferência de saber, mas um encontro de sujeitos interlocutores que buscam a significação de significados". Entende-se que não é possível a aprendizagem quando não há interlocução/entendimento, quando não existem processos de comunicação horizontalizada, quando são registrados processos autoritários que inviabilizam a liberdade de expressão.

Não se trata apenas de usar os meios de comunicação, mas recorre-se a estratégias que fomentem e facilitem o 
diálogo como, por exemplo, eliminar as filas de carteiras, organizando-as de forma a permitir o trabalho em grupos, ou acomodando-as em um círculo para que todos os presentes possam se ver. Se a proposta é abrir canais para a interlocução, é eficaz trazer à tona assuntos de interesse dos aprendentes, não menosprezando sua bagagem cultural, de forma a tornar a aprendizagem significativa para eles. O conteúdo midiático é, certamente, um desses interesses. Assim, adotar a pedagogia da comunicação pode consistir em usar o conteúdo da mídia com o objetivo de motivar e levar os estudantes a interagirem entre si, com o professor e com os conteúdos escolares (SOARES, 2014).

A pedagogia da comunicação pode ser igualmente utilizada para solucionar desafios no relacionamento entre as equipes administrativa, pedagógica e docente da unidade escolar, situação bastante frequente, uma vez que nas escolas, com frequência, se adota a comunicação vertical, não dialógica, fato agravado quando se considera que as equipes trabalham em diversos turnos, dificultando o encontro presencial dos envolvidos. O mesmo se aplica aos estudantes, pais e comunidade (SOARES, 2014).

Vale ressaltar que a diferença entre as áreas da educação para a comunicação e da pedagogia da comunicação é que o objetivo da última é criar condição para que o diálogo se estabeleça e, para a primeira, a comunicação é o tema de estudo (ALMEIDA, 2015).

Expressão comunicativa através das artes

Reúne ações realizadas, quase sempre por arte-educadores, com o intuito de assegurar espaços de fala, visibilidade e a livre expressão dos sujeitos sociais. A expressão artística é uma linguagem poderosa, capaz de conectar indivíduos dispersos e, até mesmo, aqueles portadores 
de deficiências ou com dificuldades de socialização (SOARES, 2014);

\section{Mediação tecnológica}

Visa à incorporação das tecnologias da informação e da comunicação nos processos educativos de forma a ampliar e multiplicar as oportunidades de aprendizagem, sempre privilegiando a sua utilização humanizada e colaborativa, tendo o educando e o processo de aprendizagem como o centro do processo (SOARES, 2014);

Gestão da comunicação no espaço educativo

Desenvolve e implanta projetos com o objetivo de transformar ambientes educativos em ecossistemas comunicativos. Os projetos adotam, simultaneamente ou não, atividades das demais áreas mencionadas. Lembrando que o ambiente educativo pode ser virtual, acessado a distância por receptores de um meio massivo de comunicação, mas também presencial, em escolas, empresas e organizações aprendentes. Para tanto, o gestor da comunicação realiza um diagnóstico no local, detectando as fragilidades dos processos de comunicação, ou até mesmo lacunas e identificando dificuldades de relacionamento entre os membros da comunidade, propondo e acompanhando a implantação de estratégias para ampliar o coeficiente comunicativo entre eles (SOARES, 2014).

Produção Midiática

Refere-se à "ações, programas e produtos da mídia elaborados a partir do parâmetro educomunicativo" (SOARES, 2014, p. 4). Tem como resultado produtos comunicacionais a serem exibidos em emissoras de rádio, televisão, cinema, veículos impressos, web, circuitos fechados nas diferentes organizações e em ambientes educativos virtuais, entre outros. Inclui produtos destinados à 
educação formal, materiais didáticos e de apoio à aprendizagem como jogos, vídeos, cartilhas, fanzines (ALMEIDA, 2015).

\section{Reflexão epistemológica sobre a educomunicação}

Reflexão acadêmica sobre os pressupostos da educomunicação e desenvolvimento de pesquisas que os consolidem e desenvolvam esse novo campo de conhecimento. Neste caso, as pesquisas são realizadas pelos docentes em formação ou em exercício (SOARES, 2014).

\section{Proposta interdisciplinar}

Apresenta-se uma sugestão de projeto interdisciplinar para o ensino médio, integrando as disciplinas de Língua Portuguesa, Geografia e Artes, com o objetivo de refletir sobre o gênero publicitário e a discriminação racial. Na disciplina de Língua Portuguesa os alunos estudarão as características do gênero publicitário por meio de leitura e produção de texto publicitário; em Geografia, eles analisarão a composição racial da população brasileira e nas aulas de Artes, desenvolverão um panfleto publicitário sobre discriminação racial.

As atividades sugeridas se alinharão tanto mais ao ideal educomunicativo quando em seu desenvolvimento cultivarem um ambiente de ensino participativo, dialógico, colaborativo, criativo e se forem significativas para os alunos, de onde se infere que exemplos complementares com casos regionais terão papel importante para a consolidação da aprendizagem. Outro aspecto importante é evitar a exposição de concepções pré-concebidas, o ideal é que se inicie pela fala dos alunos, por suas ideias, deixando-os discorrer livremente sobre as temáticas em 
pauta. Exemplificando: o mote disparador das discussões sobre discriminação racial serão peças publicitárias africanas, nas quais todos ou a maior parte dos personagens são negros, que serão exibidas para os estudantes sem nenhuma explicação prévia. Acredita-se que o estranhamento causado por elas suscitará o diálogo sobre: a representatividade do negro na mídia brasileira e a participação quantitativa de negros e pardos na população brasileira.

Objetivos com a atividade interdisciplinar:

- Conhecer a composição racial da população brasileira

- Refletir sobre a discriminação racial e o seu desdobramento na mídia;

- Analisar textos do gênero publicitário;

- Produzir experimentalmente textos publicitários;

- Avaliar textos orais, visuais e escritos de sua produção e de seus pares;

- Desenvolver a capacidade de argumentação, exercitando a crítica ao trabalho alheio, de forma respeitável e a autocrítica, tendo por base argumentos consistentes;

- Conviver com a crítica;

- Respeitar a opinião de terceiros.

- Trabalhar em grupo;

Material didático - sugere-se o trabalho com as seguintes peças publicitárias ${ }^{5}$

5 O download de todas as imagens pode ser feito em https:// simtvd2011.wordpress.com/racismo-e-midia/ 
Peça 1: Campanha do cereal Willards

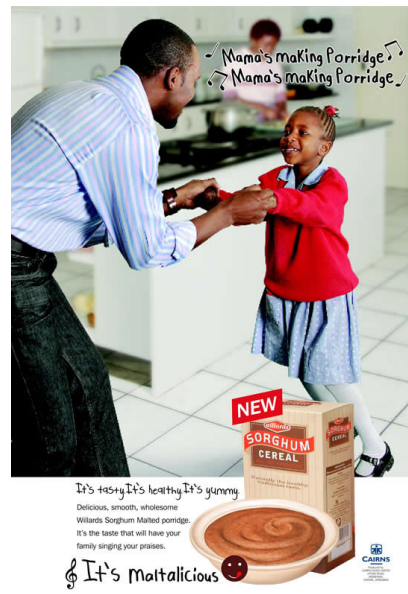

Fonte: http:/ / www.cma.co.zw/portfolio/ cairns/\#

Peça 2: Filme publicitário do MacDonald ${ }^{\prime}{ }^{6}$

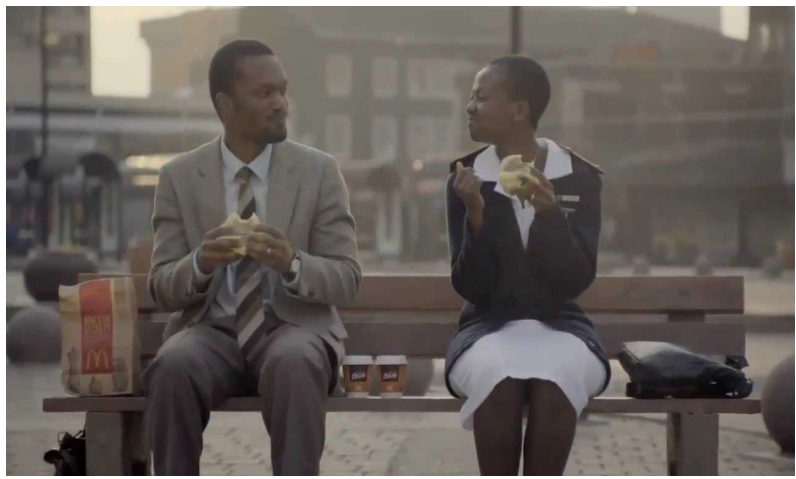

Fonte: https:/ /i.ytimg.com/vi/K_1iUNxTh3s/maxresdefault.jpg

6 O vídeo publicitário pode ser assistido em https:/ / www.youtube.com/watch?v=K_1iUNxTh3s 
Peça 3 - campanha da agência de empregos Sasol
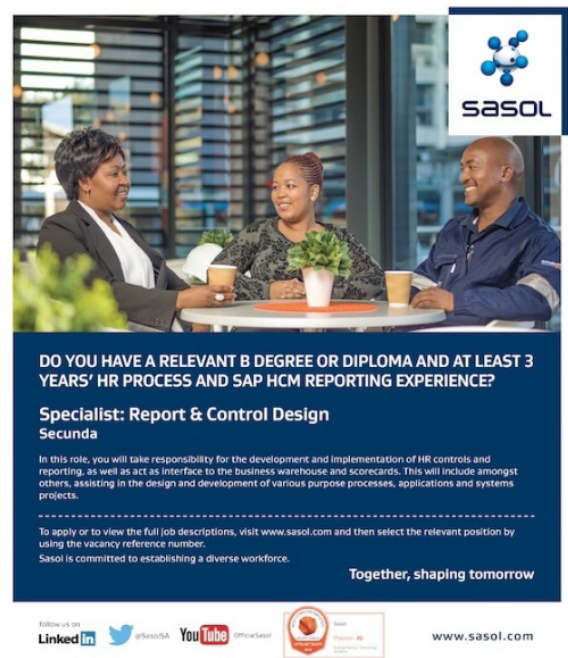

Fonte: http:/ / www.ayandambanga.co.za/our- work/ print-ads-sasol/

Peça 4 - Campanha da Unimed Cuiabá

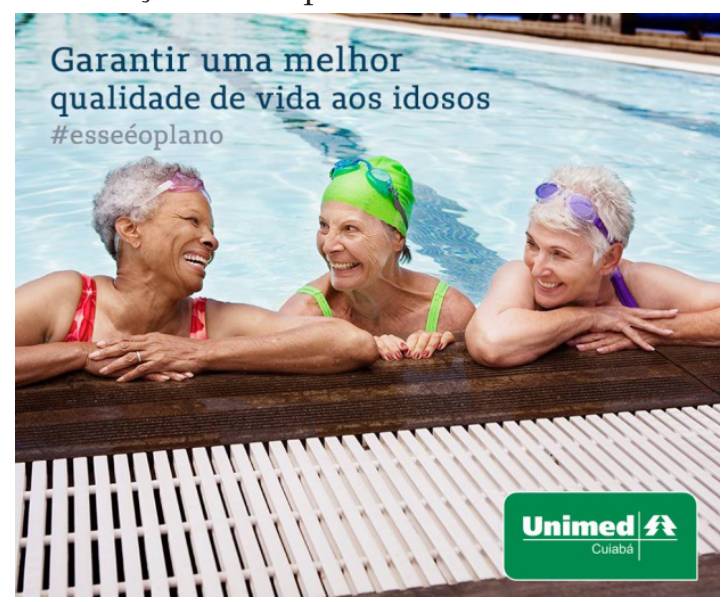

Fonte: http:/ / www.unimed.coop.br/blog/cuiaba/date/20160909 
Peça 5-Campanha Fundo Social do Idoso de Tremembé

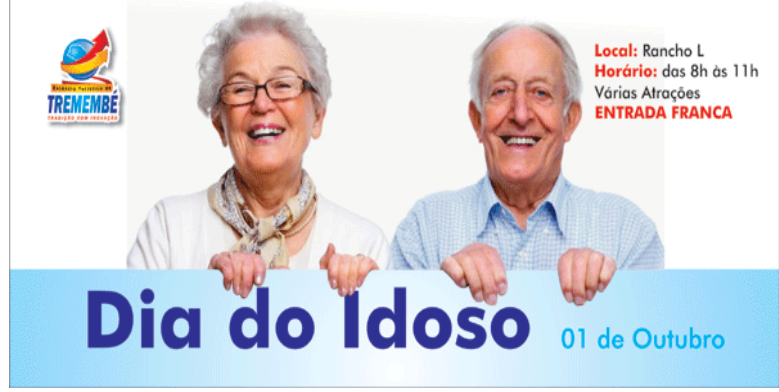

Fonte: http:/ / www.tremembe.sp.gov.br/2014/09/fundo-social-de-tremembe-promove-evento-em-homenagem-ao-dia-do-idoso/

Peça 6 - Campanha do Grupo Ghanem

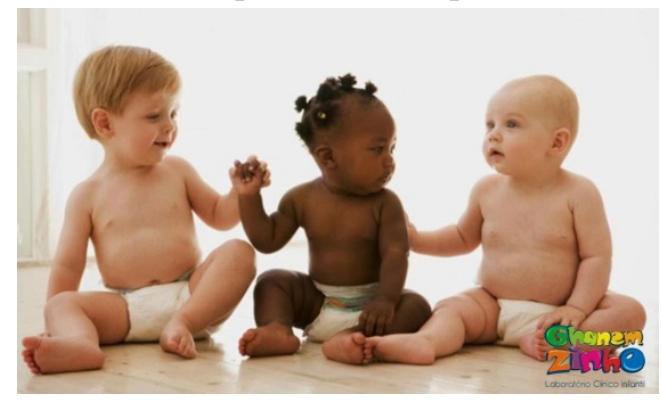

Fonte: https:/ /goo.gl/6OirD5

Peça 7 - Campanha da Johnson's

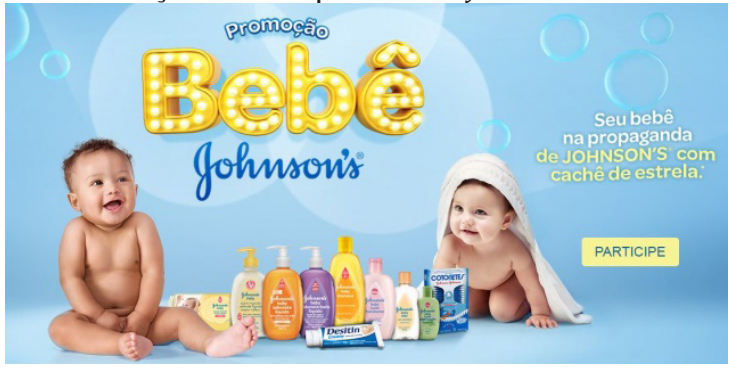

Fonte: https://goo.gl/klcJ0e 
Peça 8 - Campanha Dove

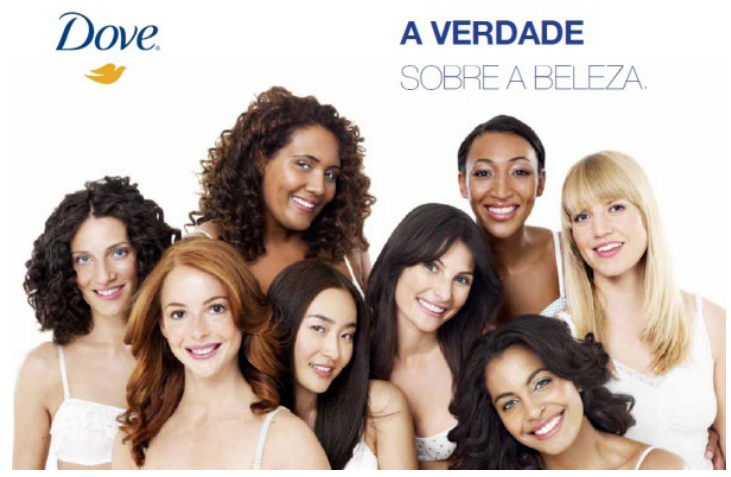

Fonte: https:/ / goo.gl/P19YV6

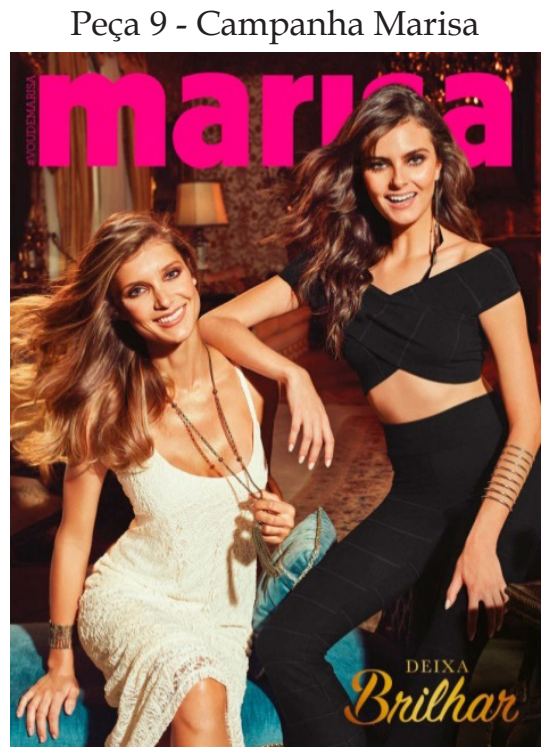

Fonte: https:/ /goo.gl/zpv57f 


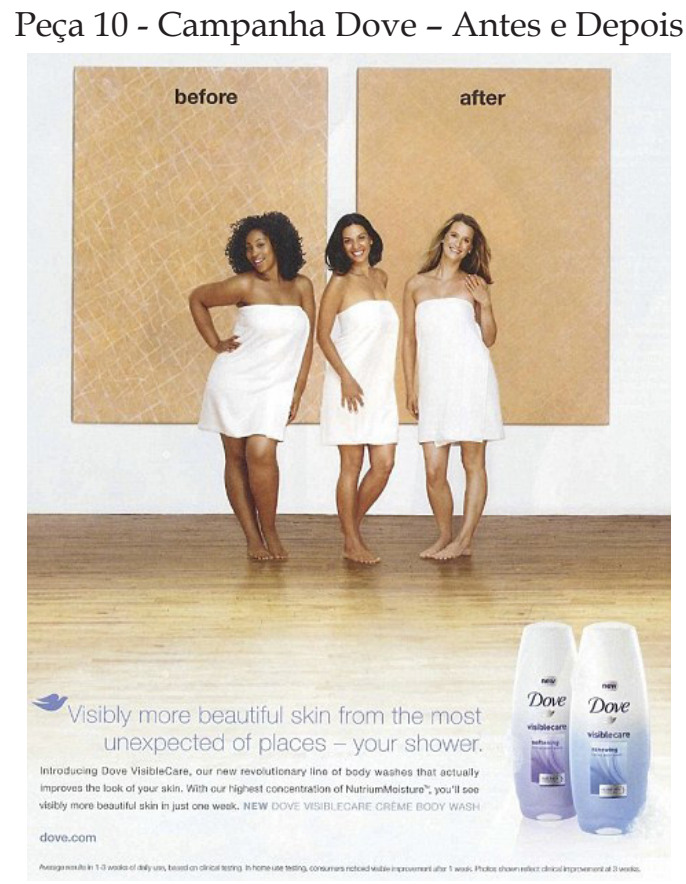

Fonte: https://goo.gl/khOYI

Passa-se agora à descrição da sequência didática a ser adotada em cada disciplina. Para todas elas, serão indicados links com leituras sobre as temáticas envolvidas.

\section{Geografia: a composição racial da sociedade brasileira}

O último censo brasileiro, realizado pelo IBGE em 2010, revelou que a maioria da população é composta por cidadãos que se declaram pardos e pretos, totalizando 50,7\% (IBGE, 2010). No debate a ser suscitado com os alunos, o principal questionamento é se eles têm sido proporcionalmente representados na mídia brasileira, considerando a 
programação televisiva, cinematográfica e impressa, formada por telejornais, telenovelas, filmes e na publicidade. Estimativa de tempo necessário para o desenvolvimento da atividade: duas aulas de 50 minutos.

\section{Metodologia e estratégias didáticas}

Momento 1 - Despertamento e análise crítica (aula de $\underline{50 \text { minutos) }}$

Exibir as imagens das campanhas 1, 2 e 3 para os alunos, deixando que eles comentem o que desejarem sobre elas. Questioná-los sobre o motivo de propagandas como essas não serem produzidas e divulgadas na mídia brasileira. Informar a eles que o Brasil é o segundo país com a maior população negra no mundo, perdendo apenas para a Nigéria, levando-os novamente a refletir sobre o motivo de propagandas como essas praticamente não serem produzidas e divulgadas na mídia brasileira.

A seguir, explicar para eles que em abril de 2002 foi aprovado o Projeto de Lei (PL) 4370/98, que instituiu cotas para representação da etnia negra nos filmes, anúncios publicitários, peças e programas veiculados pelas emissoras brasileiras de televisão ou apresentados em cinemas, tornando obrigatória a presença mínima de $25 \%$ de afrodescendentes entre os atores e figurantes dos programas de televisão e em peças de teatro - e de $40 \%$ nas peças publicitárias apresentadas nas tevês e nos cinemas. Perguntar, então aos jovens o que teria motivado a promulgação de um PL dessa natureza em um país em que mais da metade da população é de pardos e negros. Complementar a informação, revelando a posterior aprovação, em julho de 2010, do Estatuto da Igualdade Racial, que retirou a obrigatoriedade das cotas, declarando apenas que nos programas, filmes e publicidades "deverá ser 
adotada a prática de conferir oportunidades de emprego para atores, figurantes e técnicos negros" (BRASIL, 2010).

Pedir então que, com base no PL 4370/98, eles calculem hipoteticamente a quantidade de negros e pardos que deveria existir em comerciais com a presença de atores, iniciando por aqueles que contam com apenas um deles e depois com 2, 3 e 4 . Fazer com que reflitam sobre o que mudaria caso houvesse a necessidade de se manter uma proporcionalidade com a o percentual deles na população brasileira. Solicitar que façam uma pesquisa em casa, utilizando motores de busca na internet, para verificar quantos comerciais localizam com a presença de pardos e negros no Brasil.

Na sequência, exibir as peças publicitárias seguintes, respeitando os pares propostos: idosos - 4 e 5; bebês -6 e 7 e adultos -8 e 9, pedindo que verbalmente analisem em que medida as proporções são representadas. Após a manifestação dos jovens, esclarecer que quase que na totalidade das peças publicitárias brasileiras com apenas um ator, ele é branco ${ }^{7}$. E que por diversos motivos, entre eles pela necessidade de se pagar cachê aos atores, o maior percentual das propagandas acaba usando apenas um ator, o que faz com que a publicidade brasileira termine representando eminentemente a população branca, fato também justificado pela preferência de se orientar o apelo publicitário ao público de maior poder aquisitivo, formado por brancos no Brasil.

7 Opção que persiste muitas das vezes em que existem dois atores, o que pode ser observado em uma busca simples na internet. 
Momento 2 - Estudo da composição racial da sociedade brasileira (aula de 50 minutos)

Com o apoio das informações do censo do IBGE de 2010 e de gráficos, levar os estudantes a compreenderem a participação de cada raça na formação da sociedade brasileira, assim como sua divisão por faixa etária e concentração nos diversos estados do território nacional, bem como a distribuição de renda entre elas.

Textos de apoio para o docente:

- População residente, por cor ou raça no Brasil. Em: http:// www.ibge.gov.br/english/estatistica/populacao/censo2010/ caracteristicas_da_populacao/tabelas_pdf/tab3.pdf

- Comissão aprova cotas para negros na mídia. Em: http://www2. camara.leg.br/camaranoticias/noticias/18092.html

- Estatuto da Igualdade Racial. Em: http://www.planalto.gov.br/ ccivil_03/_ato2007-2010/2010/lei/112288.htm

- Retrato dos negros no Brasil. Em: http://www.redeangola.info/ multimedia/retrato-dos-negros-no-brasil/

- A questão racial brasileira e as contradições das políticas de cotas raciais. Em: http://profwladimir.blogspot.com.br/2013/04/ reflexoes-sobre-as-politicas-de-cotas.html

- Estatuto garante representação do negro na mídia. Em: http:// asideiasforadolugar.blogspot.com.br/2008/05/entrevista-estatutogarante-representao.html

- Os mocinhos da novela das nove. Em: http:/ / observatoriodaimprensa. com.br/tv-em-questao/_ed784_os_mocinhos_da_novela_das_nove/

Avaliação: Observar os testemunhos dos alunos; verificar se calcularam corretamente os percentuais de distribuição da população; avaliar os resultados de suas buscas na internet. 
Lingua Portuguesa: estudando o gênero publicitário

O texto sincrético do gênero publicitário é bastante indicado para o estudo do uso do imperativo, das figuras de linguagem, da semiose da imagem com suas rimas poéticas, bem como da relação existente entre o texto imagético e o texto escrito, na formação do sentido. A análise do texto publicitário permitirá desenvolver competências para refletir sobre o uso da linguagem e do papel ativo desempenhado pelo receptor na construção do sentido.

Material didático: campanha publicitária de número 10.

Metodologia e estratégias didáticas

Estimativa de tempo necessário para o desenvolvimento da atividade: três aulas de 50 minutos.

Momento 1 - Análise crítica de imagem (aula de 50 $\underline{\text { minutos) }}$

Leitura textual conduzida pelo docente. Em uma primeira etapa, mais superficial, a leitura poderá ser estimulada pelas seguintes questões:

- Como a imagem das mulheres é explorada no anúncio?

- As imagens de todas as mulheres são exploradas da mesma maneira?

- O grupo consegue definir a ideia de "apelo" para a venda nessa publicidade?

Na sequência, passa-se a explorá-la mais profundamente usando um percurso analítico que parte do texto, vai para o contexto e termina com julgamentos de valor: 
Descrição/denotação: identifique e liste tudo o que puder ver:

- Cenário, cor, características dos personagens, texto, logomarcas.

- Ângulos escolhidos, composição da imagem, iluminação, disposição dos elementos no espaço gráfico, linguagem corporal.

- Pense: como esses recursos são combinados no texto publicitário como um todo?

O significado do texto: observe as conotações e associações invocadas pelo texto

- Do que as imagens o fazem lembrar (sua vivência pessoal ou de outros materiais e gêneros que já tenha visto na $t v$, no cinema, na literatura).

- Analise como a iluminação, ou as cores, são usadas para estabelecer determinado clima ou atmosfera, ou como certos ângulos de câmera posicionam o leitor em relação à cena.

$\mathrm{O}$ teste da comutação dá um bom resultado: imagine como o significado do texto mudaria se um elemento fosse alterado, como, por exemplo, a idade ou sexo das personagens, a ordem que aparecem na imagem, a vestimenta, ou um estilo diferente de grafismo.

Julgamentos

- O texto como um todo veicula valores e ideologias?

- Quais as qualidades positivas com as quais o produto é associado?

- O produto é natural, familiar/caseiro, sexy, científico, vai transformar o consumidor em uma pessoa melhor, mais poderosa, sofisticada ou atraente?

- Como esse apelo pode ser identificado no texto?

- Ele é eficaz em convencer?

- Como o texto estimulou a ideia de sucesso e beleza?

\section{Momento 2 - Produção textual (aula de 50 minutos)}

Nesta etapa os estudantes são convidados, em grupos de quatro alunos, a produzir um texto publicitário, tomando como referência o conteúdo curricular que estudaram. O docente fornecerá um resumo contendo a temática a ser trabalhada (discriminação racial) e as diretrizes que os guiarão na elaboração do produto final: um 
folheto publicitário, que integrará uma campanha contra o preconceito racial na mídia, a ser divulgada no âmbito escolar.

Eles deverão redigir o texto escrito, pensar sobre as fotografias que comporão o material e planejar a diagramação do folheto. As atividades de produção de fotos e diagramação do folheto serão realizadas na disciplina de Artes.

Momento 3 - Comunicação Oral (aula de 50 minutos)

Assim que o folheto estiver pronto, o grupo deverá apresentá-lo aos colegas, defendendo e justificando as escolhas feitas pelo grupo. Ao final das apresentações, o grupo irá se reunir e comparar a sua peça publicitária com as peças produzidas pelos outros grupos e rever seus conceitos, no intuito de imaginar como seria a peça ideal caso aproveitassem os melhores atributos dos folhetos produzidos pelos grupos. Novamente, cada grupo apresenta aos outros suas percepções.

Momento 4 - Comunicação Mediada

Por fim, os estudantes afixam os folhetos produzidos em pontos estratégicos da escola.

Avaliação - verificar:

1. Interpretação do texto publicitário, com identificação do apelo contido no material;

2. Respeito às regras gramaticais e às particularidades do gênero textual estudado;

3. Envolvimento dos estudantes na atividade;

4. Aplicação dos elementos estudados no material produzido;

5. Nível de argumentação dos estudantes ao justificarem suas escolhas, considerando o folheto que criaram e, ao final das atividades, a autocrítica de cada um sobre a peça publicitária que criaram. 
Textos de apoio para o docente:

- Campanha da Dove é acusada de racismo. Em: https://acervo. racismoambiental.net.br/2011/05/25/campanha-da-dove-eacusada-de-racismo/ e https://universa.uol.com.br/noticias/ redacao/2017/10/08/dove-e-acusada-de-racismo-em-campanha-epede-desculpas.htm

- Como nasceu o viral Dove Real Beleza. Em: http:/ / exame.abril.com. br/marketing/noticias/como-nasceu-o-viral-dove-real-beleza-feitopor-brasileiros

- Panfletos. Em: http://portaldoprofessor.mec.gov.br/fichaTecnica Aula.html?aula $=21174$

- O preto onde tudo era branco: o negro também consome. Em: https:// lapecpp.files.wordpress.com/2011/05/tfg_final_eveline_pena.pdf

\section{Artes: estudando a linguagem fotográfica e a programação visual}

A análise do texto publicitário permite desenvolver competências para refletir sobre a linguagem fotográfica e sobre a composição artística de imagem e texto, tanto em um anúncio para revista quanto em um folheto publicitário. Os alunos estudarão as diferentes correntes artísticas para definir a concepção estética que usarão em seus folhetos.

$\mathrm{Na}$ aula de língua portuguesa eles desenvolverão o texto de seus anúncios e na aula de artes, a concepção visual e a fotografia que o comporá.

Materiais: será necessária a utilização de máquina fotográfica, que pode ser a disponível em aparelhos celulares e também de computadores, que serão operados coletivamente. 


\section{Metodologia e estratégias didáticas}

Momento 1 - Análise de texto (aula de 50 minutos)

Análise textual das campanhas apresentadas nas

figuras 1 e 2, que enfocará a composição da imagem como um todo, as cores, a tendência estética presente, a relação entre texto e imagem, além da família de fontes utilizadas.

Momento 2 - Estudo da linguagem da fotografia publicitária (aula de 50 minutos)

Esta etapa compreende o estudo da linguagem fotográfica e a identificação de seus recursos no folheto publicitário analisado: os planos de captação utilizados, a iluminação, o enquadramento dos objetos, o que pode ser feito utilizando-se conceitos sobre codificação da linguagem fotográfica, apresentados no quadro a seguir:

\begin{tabular}{|c|l|}
\hline CONCEITO & \multicolumn{1}{c|}{ O QUE É } \\
\hline TRUCAGEM & $\begin{array}{l}\text { - Procedimento no qual o fotógrafo aproxima } \\
\text { artificialmente em uma imagem duas outras que se } \\
\text { encontravam distintas no ato da fotografia. As duas } \\
\text { imagens separadas têm um sentido, mas quando juntas } \\
\text { numa terceira imagem, assumem um sentido diferente. }\end{array}$ \\
\hline POSE & $\begin{array}{l}\text { - Parte do princípio que existem significantes } \\
\text { estereotipados no constituinte da imagem. Esta imagem, } \\
\text { segundo Barthes, deve ser tratada como uma dupla } \\
\text { estrutura, denotada-conotada. Funciona como uma } \\
\text { "gramática histórica" da conotação iconográfica. }\end{array}$ \\
\hline OBJETOS & $\begin{array}{l}\text { - Funcionam como indutores para associações de ideias. } \\
\text { Sua função, portanto, é de significar. Os objetos são } \\
\text { signos completos em si mesmos, o que, para o autor é } \\
\text { uma qualidade, pois são descontínuos e léxicos, portanto, } \\
\text { tornam-se simples e criam um discurso a partir deles } \\
\text { (sintaxe). }\end{array}$ \\
\hline
\end{tabular}




\begin{tabular}{|c|l|}
\hline CONCEITO & \multicolumn{1}{|c|}{ O QUE É } \\
\hline FOTOGENIA & $\begin{array}{l}\text { - No processo de fotogenia, o fotógrafo usa recursos } \\
\text { como enquadramento, composição, iluminação, } \\
\text { velocidade do obturador, podendo embelezar coisas que } \\
\text { não são bonitas na realidade. }\end{array}$ \\
\hline ESTETICISMO & $\begin{array}{l}\text { - No processo de esteticismo, o fotógrafo usa recursos } \\
\text { como cor, iluminação, textura para construir imagens } \\
\text { que lembram obras de arte, o que induz a um sentido } \\
\text { foto recebe tratamento, ela deve ser tratadia como arte. } \\
\text { Mesmo assim, ela possui algumas diferenças essenciais } \\
\text { se comparada à pintura. }\end{array}$ \\
\hline SINTAXE & $\begin{array}{l}\text { - Uma leitura discursiva de objetos-signos contidos } \\
\text { na fotografia. Tem por função levar a comicidade, } \\
\text { pelo encadeamento de fotos. No processo de sintaxe, } \\
\text { o diagramador aproxima na página uma determinada } \\
\text { sequência de fotos que, juntas, adquirem um sentido } \\
\text { diferente daquele se essas imagens fossem lidas } \\
\text { separadamente. }\end{array}$ \\
\hline ANCORAGEM & $\begin{array}{l}\text { - No processo de conotação texto-imagem, o editor } \\
\text { acrescenta uma legenda ou slogan que direcionam a } \\
\text { imagem para uma leitura desejada. O texto também pode } \\
\text { estar presente dentro da fotografia e, assim, modificar o } \\
\text { sentido de maneira muito mais sutil. }\end{array}$ \\
\hline
\end{tabular}

Fonte: Quadro adaptado por Alexandra Bujokas de Siqueira e Liana Catharina de Carvalho de conceitos formulados por Roland Barthes no texto "A mensagem fotográfica". Disponível em http:/ / www.slideshare.net/cetbujokas2011/ aulas-9-10-e-11-fotografia.

Momento 3 - Produção textual ( 3 aulas de 50 minutos cada)

Em grupos de 04 alunos, os estudantes serão convidados a produzir uma peça publicitária, tendo como referência o conteúdo curricular que estudaram. O professor de artes trabalhará com o mesmo resumo fornecido pelo 
professor de língua portuguesa, contendo a temática a ser abordada e o produto final a ser produzido: um folheto publicitário, que integrará uma campanha contra o preconceito racial a ser divulgada no âmbito escolar. Prevê-se que na primeira aula eles desenvolvam a concepção artística e planejem a produção, na segunda, produzam a fotografia e na terceira, diagramem o folheto na sala ambiente de informática.

- Orientações a serem fornecidas para produção dos anúncios pelos alunos: defina o público alvo, descubra o que o sensibiliza, o que ele anseia, elabore estratégias para associar a ideia a ser divulgada com um valor que seja apelativo para o público alvo, finalmente, crie a mensagem unindo o apelo à ideia a ser "vendida".

- Tutoriais para montagem de folheto no Corel e Photoshop

É possível montar folhetos usando softwares de operação bastante simples como o Word ou o Power Point. $\mathrm{Na}$ internet é possível encontrar uma série de tutoriais para operar programas de edição. Caso seja feita a opção por usar ou por desafiar os alunos a usarem programas mais sofisticados é possível trabalhar com o Corel Draw ou o Adobe Photoshop.

A seguir algumas sugestões de links que dão acesso a tutoriais:

- http://office.microsoft.com/pt-br/templates/ folheto-de-tres-dobras-de-negocios-design-civico-TC010203493.aspx

- http://www.youtube.com/watch?v=ohjsGa $\operatorname{lin} 98$

Há softwares livres para diagramação, como o Scribus, que pode ser obtido no link https:/ / scribus.softonic.com. 
br/ etutoriais para trabalhar com ele, comoo disponívelem: https://www.youtube.com/watch?v=Cgms7BBvEqA Momento 4 - Comunicação Oral (aula de língua portuguesa)

$\mathrm{Na}$ aula de língua portuguesa, farão a exposição do material finalizado aos colegas, justificando o porquê das escolhas feitas pelo grupo. Será o momento também de compará-lo com as peças produzidas pelos outros grupos, definindo como seria a peça ideal caso aproveitassem os melhores atributos do folheto produzido por cada grupo. A última etapa será a exposição dos folhetos na escola.

Momento 5 - Comunicação Mediada

Por fim, os estudantes afixam os folhetos produzidos em pontos estratégicos da escola.

\section{Avaliação}

Verificar: o envolvimento dos estudantes na atividade; a aplicação dos elementos na análise, a manipulação e aplicação dos conteúdos curriculares, o nível de argumentação ao justificarem suas escolhas considerando o folheto que criaram, a dinâmica do trabalho em grupo e o respeito aos prazos fornecidos.

Textos de apoio:

- Contribuições para uma história da análise da imagem no anúncio publicitário. Em: http://pt.scribd.com/doc/15707459/analise-daimagem-Roland-Barthes

- Composição Fotográfica. Em: http:/ / portaldoprofessor.mec.gov.br/ fichaTecnicaAula.html?aula=15076 


\section{Conclusão}

Nesta proposta são trabalhados conteúdos curriculares e conteúdos da mídia de forma a tornar a aprendizagem significativa e motivadora, além de atender às normativas que norteiam a educação no Brasil. Com o objetivo de colaborar com a construção do conhecimento nas escolas, mobilizam-se saberes delineados em três áreas de intervenção educomunicativas: a educação para a comunicação, a pedagogia da comunicação e a expressão através das artes.

Refletindo sobre e produzindo textos do gênero publicitário, o aluno adquire conhecimentos sobre a língua portuguesa presente no seu cotidiano. Discutindo a publicidade, ele faz a leitura crítica e estética de textos artísticos, nos quais a fotografia se enquadra, além de expressar-se através das linguagens artísticas.

Desenvolve também competências e habilidades almejadas pela educação e pela educomunicação e necessárias à formação do cidadão crítico com capacidade de inserção nos mais diversos ambientes sociais: refletir sobre textos, orais e escritos, produzidos pelo aluno e por seus pares; trabalhar em grupo; desenvolver a capacidade de argumentação, exercitando a crítica ao trabalho alheio de forma respeitável e a autocrítica, tendo por base argumentos consistentes; conviver com a crítica e respeitar a opinião de terceiros.

Ao criar folhetos publicitários, o objetivo da educação para a comunicação será alcançado, uma vez que o estudante desenvolve um olhar mais crítico sobre a mais poderosa ferramenta de sustentação econômica da cultura midiática: a indústria publicitária. 
Ressalta-se que a metodologia proposta, além de propor a análise crítica, também leva ao uso criativo das mídias, afinal, o aluno é incentivado a ser produtor de conteúdo. A discussão sobre a produção responsável e ética certamente estará presente na produção das atividades, o que torna-se altamente relevante ao considerar que muitos jovens têm mídias sociais, portanto, utilizam seu direito de livre expressão, porém, muitas vezes sem refletir sobre sua responsabilidade nesse processo comunicativo.

No caso específico da temática abordada, é possível apostar tanto na redução nas atitudes de discriminação racial entre os discentes da unidade escolar quanto na socialização pelos estudantes, dos saberes adquiridos na escola, com a comunidade alocada em seu entorno.

\section{Referências}

ALMEIDA, Ligia Beatriz Carvalho de. Projetos de intervenção em educomunicação. Disponível em: http:/ / issuu.com/ ligiacarvalho77/docs/as__reas_de_interven___o_da_ educo/1. Acesso em: 07 out. 2016.

BIZONI, Alessandra Moura. Educomunicação: uma revolução na sala de aula. Folha Dirigida, Rio de Janeiro, 20 dez. 2005. Disponível em: <http://www.usp.br/nce/ wcp/exe/public.php?wcp=/novidades/informe,7,502>. Acesso em: 07 out. 2016.

BRASIL. Constituição da República Federativa do Brasil, 1988. Disponível em: <http://www.planalto.gov.br/ccivil_03/ constituicao/constitui\%C3\%A7ao.htm>. Acesso em: 07 out. 2016. 
BRASIL, Ministério da Educação. Lei $n^{0}$ 9.394, de 20 de dezembro de 1996. Disponível em: <http://www.planalto.gov.br/ccivil_03/Leis/L9394.htm>. Acesso em: 07 out. 2016.

. Lei $n^{0}$ 12.288, de 20 de julho de 2010. Disponível em: <http://www.planalto.gov.br/ccivil_03/_ato20072010/2010/lei/112288.htm>. Acesso em: 07 out. 2016.

EUROPEAN COMISSION. Current trends and approaches to media literacy in Europe, 2007. Disponível em: < http:/ / ec.europa.eu/culture/library/studies/literacy-trends-report_en.pdf>. Acesso em: 07 out. 2016.

FREIRE, Paulo. Extensão ou comunicação? Rio de Janeiro: Paz e Terra, 2002.

IBGE. Censo Demográfico 2010. Disponível em: <http:// www.priberam.pt/dlpo/ecossistema>. Acesso em: 07 out. 2016.

MEC. A Base Nacional Comum Curricular do Ensino Médio, 2017. Disponível em: < http://basenacionalcomum.mec.gov.br/wp-content/uploads / 2018/04/ BNCC_EnsinoMedio_embaixa_site.pdf $>$. Acesso em: 24 maio 2018.

PCN+ Ensino Médio - Orientações Educacionais Complementares aos Parâmetros Curriculares Nacionais das Linguagens, Códigos e suas Tecnologias. Disponível em: <http://portal.mec.gov.br/seb/arquivos/pdf/linguagens02.pdf $>$. Acesso em: 25 maio 2018. 
PRIBERAM. Dicionário da Língua Portuguesa. Ecossistema. Disponível em: <http://www.priberam.pt/dlpo/ecossistema>. Acesso em: 07 out. 2016.

SALVATIERRA, Eliany. Rádio e escola: a tecnologia a serviço de ecossistemas comunicativos e do protagonismo juvenil. Disponível em: <http://webeduc.mec.gov.br/ midiaseducacao/material/radio/radio_intermediario/ ecossistemas.htm>. Acesso em: 07 out. 2016.

. Ecossistema cognitivo e comunicativo. Texto apresentado na disciplina "Educomunicação: fundamentos, metodologias e áreas de intervenção". Disponível em: < http://www.usp.br/nce/wcp/arq/textos/201.pdf/> Acesso em: 07 out. 2016a.

SOARES, Ismar de Oliveira. Alfabetização e Educomunicação: o papel dos meios de comunicação e informação na educação de jovens e adultos ao longo da vida. Núcleo de Comunicação e Educação da Universidade de São Paulo, São Paulo, p.1, [2004?]. Disponível em: <http://www. usp.br/nce/wcp/arq/textos/89.pdf >. Acesso em: 07 out. 2016.

- Quando o Educador do Ano é um educomunicador: o papel da USP na legitimação do conceito. Comunicação \& Educação, v. 13, n. 3, 2008.

. Educomunicação: o conceito, o profissional, a aplicação. São Paulo: Paulinas, 2011.

. Construção de roteiros de pesquisa a partir dos livros da coleção Educomunicação (Editora Paulinas). 
Comunicação \& Educação, Brasil, v. 19, n. 2, p. 135-142, set. 2014.

. A Educomunicação na América Latina: apontamentos para uma história em construção. In: Roberto Aparici. (Org.). Educomunicação para além do 2.0. 1 ed. São Paulo: Paulinas, 2014b, v. 1, pp. 7-27, 2014. 



\title{
FORMAÇÃO DE PROFESSORES E PRÁXIS EDUCATIVO-COLETIVA
}

\author{
Antonio Roberto Faustino da Costa ${ }^{1}$ \\ José César dos Santos ${ }^{2}$ \\ Pedro Bergamo ${ }^{3}$
}

1 Professor do Departamento de Comunicação Social e do Programa de Pós-Graduação em Formação de Professores da Universidade Estadual da Paraíba (UEPB), campus I. Líder do Grupo de Pesquisa-Ação Formação de Professores e Práxis Educativo-Coletiva (UEPB/IFPB/FASB/CNPq). Doutor em Educação (UFPB). Atua e orienta nas seguintes áreas de pesquisa-ação: educação e comunicação; tecnologias de informação e comunicação, tecnologias educacionais e educação a distância; políticas educativas e formação inicial e continuada de professores; e práxis educativo-coletiva. robertofaustino@ gmail.com

2 Membro do Grupo de Pesquisa-Ação Formação de Professores e Práxis Educativo-Coletiva. Mestre em Biblioteconomia (UFPB). Atua nas seguintes áreas de pesquisa-ação: educação e comunicação; formação continuada de professores; e práxis educativo-coletiva. cesarjsantos@hotmail.com

3 Membro do Grupo de Pesquisa-Ação Formação de Professores e Práxis Educativo-Coletiva. Mediador do Grupo de PesquisaAção CONSER e pesquisador educacional da Faculdade São Francisco de Barreiras-BA (FASB). Doutor em Sociologia e pós-doutor em Educação (UNICAMP). Atua nas seguintes áreas de pesquisa-ação: economia, sociologia e educação; formação de professores; e práxis educativo-coletiva. pbergamo@fasb. edu.br 


\section{Preâmbulo}

No título em epígrafe, justapor formação de professores a uma determinada práxis é procedimento que incide em caracterizar esta práxis de forma condizente com o recorrente começo da educação, esta em sentido radicalmente amplo e a advir de adultos que se constituem em fonte de objetos de ensino e de aprendizagem (educacionais) para as pessoas ainda imaturas, ou seja, para os indivíduos que compõem as mais novas e sucessivas gerações.

Já os saberes que correspondem a tais objetos precisariam significar referência e fundamento, ou seja, orientação e embasamento para que esses indivíduos venham a se situar em múltiplas e variadas circunstâncias e, então, lhes ser possível agir e/ou reagir em acordo com a sua própria adultez.

Neste horizonte de prevalência dos saberes em foco, os concernentes objetos também precisariam existir de modo propriamente ôntico, ou seja, a deter "propriedade empírica" (física ou objetivamente perceptível, para ser representada, pensada ou abstraída), enquanto jovens aprendizes seriam favorecidos por entrarem em contato com tal condição de existência daqueles objetos de saber e, por isso, adquirir competência para conceber a forma propriamente ontológica ${ }^{4}$ como tais objetos estão a lhes ser apresentados.

4 Recorre-se à expressão "forma propriamente ontológica", bem como, à expressão correspondente a "modo propriamente ôntico", para prevenir confusão com ontológico, que, conforme Heidegger (apud ABBAGNANO, 2007, p. 848), precisa ser colocado enquanto possibilidade ou necessidade de algo deter a condição de existir, detenção que depende de "[...] uma 
Tal competência, caso já fosse efetiva na história pessoal de quem aprende, coincidiria com testemunho da pré-existência de "indivíduos-sujeitos" (fontes humanas de difusão e inclusive de produção de saberes) que recorram a formas propriamente ontológicas (imagens, figuras e ideias), às quais correspondam objetos ônticos, implicando que este testemunho, por ele mesmo, incida em realidade educativa.

Entretanto, tais "indivíduos-sujeitos" têm persistido, no âmbito da prática docente, irrefletidamente expostos a se distanciarem da autenticidade desse testemunho, à conta de que as formas de ensinar têm adentrado confusão com os modos de aprender.

Por isso, reconhecer essa confusão há de perfazer necessário ponto de partida na perspectiva de que práxis educativo-coletiva venha a significar ultrapassagem da falta de objetividade.

Entretanto, na ausência desse reconhecimento, o futuro objeto de trabalho de todo(a) aprendiz precisaria coincidir, presumidamente, com o conteúdo em processo de ensino pelo próprio docente, em vez de tal aprendiz vir a assumir-se como um inequívoco "indivíduo-sujeito" a enxergar e a entender a condição ôntica da existência de objeto ocupacional e também enxergar-se e entender-se enquanto tal "indivíduo-sujeito" que, para tanto, cumpriria vir a ser inequivocamente produtivo e, neste mister, proceder de modo propriamente ôntico.

Em razão da necessidade dessa ultrapassagem, cumpre ir além da confusão entre forma de ensinar e modo de

atitude tal em relação ao ente que o deixe ser em si mesmo, no que é e como é". 
aprender, bem como assumir que a forma propriamente ontológica dos objetos educacionais está a ser sonegada pelo exercício de poder provindo de educadores e dirigido aos educandos, mediante "[...] visão transmissivista, aristocrática, com a valorização da memória, cópia, conteúdos formais, estanques, etc." (TREVISAN; GALINDO, 2014, p. 456).

Simultaneamente à sonegação em foco, os próprios educandos exercem poder sobre os educadores, mediante desinteresse em relação aos conteúdos abordados (TREVISAN; GALINDO, 2014). Trata-se de desinteresse que opõe, de uma parte, a atitude de exercitar poder de forma impropriamente ontológica e, de outra, a atitude de sujeito inequivocamente produtivo a se conduzir de modo ôntico.

Por força daquela sonegação e desse desinteresse, inescapabilidade de condição ôntica de futuros objetos ocupacionais, junto aos aprendizes, cumpriria significar que o caráter propriamente ontológico dos objetos educacionais, estes junto a docentes, se desvele mediante efetiva mudança do processo educativo, tendo-se em vista que tal mudança há de preceder, necessariamente, àquela da sociabilidade humana cuja condição de existência, antes complicada do que complexa, encontra-se já instalada à conta de estritas relações de poder.

Paralelamente, impõe-se o desafio de abordar esta complicada condição da sociabilidade humana, à vista do caráter mítico em que incide a pressuposição de existir um exterior da totalidade sedutoramente mais "eficaz" desta mesma sociabilidade, exterior a partir do qual apenas um sujeito falsamente referenciado e embasado se encontrasse a pensar e a agir. 
Trata-se de pressuposição que, em uma perspectiva histórica de longuíssimo prazo, tem persistido inamovível, porque apelar ao imaginário do exterior em foco se generalizou junto às fontes de defesa preventiva contra agressão que se tornara estrutural. Já essa defesa, por força da inamovível situação na qual ela ainda está a prevalecer, passou a se constituir em ameaça de diversas ordens. Além disso, sempre se implicou em astronômica custosidade que está a incidir, não apenas em prejuízos materiais, mas, especialmente, em indignidade humana.

Ao se falar de indignidade humana, torna-se necessário indicar o modo como ela passou a existir na condição de mero satélite de um outro ou novel modo no qual incorre a emergência dos objetos técnicos (SIMONDON, 2007), recorrentemente exposta às mistificações que decorrem de projeções do pensar a precederem artifícios do agir, ambos ilimitados. Trata-se de incorrência pela qual a condição ôntica da dignidade humana está a ser preterida em favor das mistificações em foco. Já essa preterição, de forma especialmente fenomênica, está a aparecer enquanto situação sempre mais indireta na qual passou a coincidir o intercâmbio orgânico entre metabolismo humano e natureza livre.

Entretanto, a condição orgânica desse intercâmbio é radicalmente incompatível com a mitificação que está a se insinuar, por inexplícito que isto esteja a ocorrer, para incidir em mediadora, até mesmo excludente, daquela situação sempre mais indireta.

Por sua vez, a incompatibilidade em foco tem que prevalecer contra o caráter ilimitado das projeções do pensar e dos artifícios do agir, uma vez que aquela condição orgânica perfaz inegável objetividade e, por isso, tais 
projeções e artifícios se implicam em limites para se inserirem na interioridade do processo de inadiável mudança da vigente sociabilidade humana, inserção que cumpre ocorrer nas antípodas de presumir um exterior da totalidade desse mesmo processo e tal presunção faculte que mistificações julguem dispor de apoio para continuarem a insinuar revoluções, inclusive violentas.

Assim, pensamento de caráter propriamente ontológico ("onticológico", a bem dizer) e ação de feitio objetivo (ôntico, em rigor), ambos têm que se apoiar, existencial-limitadamente, em realidades humanas que incidam em modo comum, universalizado e múltiplo, para indutivamente se inteirarem em conjunto(s) de variada abrangência.

Em busca desta inteiração e de pertinente viabilidade enquanto mudança a ocorrer nas entranhas, sempre carentes de visibilidade, da vigente sociabilidade humana, urge que seja ao menos vislumbrada alternativa de objeto educacional enquanto elemento dessa sociabilidade, o qual, para tanto, incida em caráter universal, genérico ou comum. Trata-se de elemento a ser proposto na perspectiva de transmutar práticas, tanto docente quanto discente, em práxis educativo-coletiva que, por sua vez, cumpra ser referência e fundamento de uma bem determinada e situada formação de professores.

\section{Da Prática Educacional à Práxis Educativo-Coletiva}

Entendimento do que cumpre incidir em práxis educativo-coletiva há de provir da abordagem da sua negação enquanto mitificada prática pedagógica, ou seja, cumpre ultrapassar tal prática em cuja reprodução tem sido 
constatável o reflexo de pronta e espontânea anuência a desfrutar poder por parte de majoritária proporção dos seus próprios sujeitos, proporção que, a tanto, está a desvelar-se inclinada, especialmente no âmbito das relações entre docência e discência, assim como entre discência e docência.

Neste âmbito, desfrute de poder junto à docência costuma instalar-se à base de termos passíveis de múltiplas interpretações, incidindo no risco de sonegar conceitos, o que facilita antes informar do que ensinar; ao passo que, junto à discência, trata-se de rendição à comodidade de apenas escutar o que é informado, ou mesmo, de contentar-se em subjetivar os teores da fala docente, os quais, por isso, correm também risco de serem internalizados de forma imprecisa.

Ainda no âmbito das relações em foco, aferir a devida aprendizagem costuma incorrer naquele mesmo desfrute, tendo-se em vista, não só diminuição de pertinentes eventos como também apelo a provas, de preferência àquelas tidas por objetivas, além de rendição pouco ou nada transparente a condescendências recíprocas que, não raro, têm desandado em incúria, seja do rigor avaliativo, seja da prevenção do risco de insatisfação recíproca, ou mesmo de conflito entre aferente e aferido, este usualmente múltiplo e aquele único.

Poder assim desfrutável também cabe ser admissível no tratamento dos objetos de aula, os quais têm como ser abordados de forma sempre mais analítica e/ou extensa, especialmente se esta forma implicar empenho pessoal menos intenso, nem tanto para comunicá-los, mas para apreendê-los enquanto aparentemente singulares. A própria intensidade de empenho costuma ser contornada por 
recurso a linguajar, recorrentemente reclamado por discentes, inclusive, que até mesmo se esgote em dissertar à base de palavras e/ou expressões de significado polissêmico, tais como trabalho, amor etc., em vez de sentido unívoco, a exemplo de excedência de produção fora da propriedade de quem a gera. Por seu turno, significados assim polissêmicos chegam a comprometer a comunicação de conceitos, isto é, de categorias sobre algo que existe e, por isso, propriamente ontológicas.

Diversamente, esse empenho se intensifica ao se deter, não apenas a enxergar e a explicitar o mais referencial (de orientação) e o mais fundamental (de embasamento) do conteúdo de ensino, mas também a abreviar extensão dos teores disciplinares enquanto objeto de comunicação ou de leitura. Trata-se, todavia, de abreviação que incorre na forma sintética da apreensão daqueles teores, ou seja, no que concerne tanto à sua abrangência quanto à sua especificidade.

Já em perspectiva político-institucional - esta de teimosa presença na ambiência educacional à conta de admitida inevitabilidade da relação de poder aí também vezeira - as práticas pedagógicas têm manifestado propensão a coincidirem com meras aparências, em vez de indubitáveis realidades, da preponderância de oposição entre caráter estatal e feitio civil da prestação e da aceitação de serviços educacionais junto aos respectivos sujeitos ${ }^{5}$.

5 A presença da político-institucionalidade em foco "[...] se desvela nas esferas estatal e civil, de tal forma que nesta última esfera se processe criteriosidade de prática educativa no intuito de prevenir riscos de esta prática vir a ser fragilizada à insistência de serem incontrolavelmente reproduzidos certos aspectos dos sistemas educacionais, os quais se fazem valer, mediante 
Por força de tais aparências, facilitação informativa e comodismo receptivo dos assuntos de aula e/ou lidos, ambos - facilitação e comodismo - têm estado expostos a desfrute de poder, além de que interesse passa a ser imediatistamente associado a tal desfrute. Já este interesse costuma prevalecer, junto a docentes, à conta da estabilidade enquanto prerrogativa de posto de trabalho na esfera estatal.

Junto a discentes, por inexplícito que o ocorra, há interesse por futuro posto de trabalho, em vez de resignação às condições de meramente trabalhar, ou seja, em vez de virem a deparar objeto de trabalho, cujo status quo buscam relegar, sem disto até mesmo se darem conta, a plano secundário de conveniência ou ainda menos assim categorizado.

Paralelamente, tem existido diferenciação - esta, antes implícita do que de antemão percebida - a respeito do que valorar como objeto em relação a posto, ambos enquanto questão ocupacional. Trata-se de diferenciação que tem como perfazer reflexo da prevalência de meras práticas no âmbito do processo educacional, pois, junto à futura condição de egresso(a) deste processo, aquele objeto persiste pura e simples incógnita, enquanto esse posto teria que se objetivar em nada mais nada menos do que nas próprias práticas educativas. Já a falta desta objetivação precisa ser explicada, levando-se em consideração que essas mesmas práticas ainda se encontram alheadas a "em que" educar cuja onticidade lhes faculte coincidir com mediação para

métodos tradicionais de ensino e de avaliação de aprendizagem contra os quais aquela criteriosidade há de afirmar-se." (LUCENA, 2015, p. 128) 
enxergar e conceber objeto em vez de se aterem a estritas formalidades, tais como didática, pedagogia, ensino e, até mesmo, educação.

Tal alheamento não se tem encontrado isento de ser assumido, à conta de práticas carentes de identidade própria, disto havendo testemunho na peculiarmente abalizada referência de Saviani (2009, p. 73-74, grifos nossos):

Entendo que educação e política, embora inseparáveis, não são idênticas. Trata-se de práticas distintas, dotadas cada uma de especificidade própria.

Em que consiste a especificidade de cada uma dessas práticas?

O problema de se determinar a especificidade da educação coincide com o problema do desvendamento da natureza própria do fenômeno educativo. Trata-se de uma questão nodal que vem ocupando o centro de minhas reflexões nos últimos anos. Penso que é necessário enfrentá-la e acredito dispor já de algumas evidências que me indicam a direção que deverei seguir para elucidar tal questão [...]

À base dos teores grifados nesta citação, coloca-se outro problema em vez daquele apresentado pela fonte em apreço. Trata-se de uma necessária disjunção entre a educação e a política, tendo-se em vista que as condições de existência da primeira têm persistido determinadas pela segunda. 
Nestas condições, a política tem logrado proceder de forma absolutizada, apelando, para tanto, a ilimitadas projeções do pensar dos pertinentes sujeitos a respeito dos destinos da educação, enquanto a efetivação destes destinos propende a refletir tais projeções através de artifícios do agir ainda carentes de limites para corresponderem à objetividade que venha a lhes facultar se caracterizarem como propriamente educativos.

Assim, cumpre que a educação logre se emancipar e a novidade desta condição somente há de ocorrer de forma reflexiva, ou seja, após os concernentes sujeitos enxergarem que o "em que" educar está obscurecido à absolutização da política.

Já esses sujeitos precisam deparar objeto em que a educação mesma se constitua, ao corresponder, de forma indubitável, à realidade desse "em que" educar. Assim, ela passa a incidir em objetividade a toda prova.

Todavia, ao continuar sem deter objeto próprio, a educação tem sido invadida por multiplicidade de objetos impróprios, fenomênicos e meramente aparenciais. Por isso, os seus egressos têm sido induzidos a se conduzirem de modo incompatível com os limites que caracterizam a condição orgânica do intercâmbio entre metabolismo humano e natureza livre, não precisando vir a ter sequer intenção de se conduzirem de modo alternativamente compatível, por conta de espontâneo apelo à absolutização da liberdade, ao persistir aquela invasão de objetos.

Entretanto, omissão educacional está a implicar que seus egressos, inclusive do ensino tido por superior, ou mesmo universitário, persistam a reduzir sujeito a mero objeto, ou seja, a confundir apropriação com produção 
dos resultados do agir humano, em resposta a ilimitadas projeções do pensar, apesar de estas projeções não dispensarem ensino para serem engendradas.

A propósito de confundir apropriação com produção, a desandar em imprecisões filosóficas sobre o trabalho, Lukács (2003, p. 20) - ninguém mais do que um dos mais expressivos expoentes do pensamento filosófico mais recente - veio a admitir, ainda que de forma peculiarmente implícita, imprecisão filosófica de teores da mais difusa das suas obras, ao não apelar à categoria do trabalho enquanto o ponto de partida desta mesma obra e, por isso, chega a tecer uma inegável autocrítica:

Tais imprecisões filosóficas servem de punição para a História e consciência de Classe que, ao analisar os fenômenos econômicos, busca seu ponto de partida não no trabalho, mas simplesmente em estruturas complexas da economia mercantil desenvolvida. Com isso, perde-se de antemão a perspectiva de um salto filosófico em direção a questões decisivas, como a da relação entre teoria e prática, ou sujeito e objeto.

A respeito dos teores desta citação, cumpre considerar que a relação entre teoria e prática e a relação entre sujeito e objeto correspondem, respectivamente, à práxis e à mediação, além de que educação coincide com mediação. Ademais, cumpre assumir que a educação, desde a paideia helênica, passou a deter seu ponto de partida nas 
estruturas complexas das "técnicas culturais" - significado filosófico mais original de tudo o que tem sido ensinado e aprendido mediante educação (ABBAGNANO, 2007, p. 357) -, afastando-se do trabalho enquanto categoria cuja precisão filosófica cumpriria ser depurada primordialmente por educadores, à razão de que a prática do trabalho está inegavelmente contida no processo educativo.

Assim, urge aos sujeitos da educação propor que o objeto do seu próprio trabalho incida em realidade física ou ôntica cuja representação se implique em categoria o quanto possível inequívoca. Para tanto, este objeto cumpre não deter, por trabalho que o processe, aquele que tem coincidido com o estrito apropriar resultados de outros, do educativo antes de todos os demais.

Então, o objeto do trabalho educativo precisa ser representável, imediata e limitadamente, ou seja, adentre a precisão de significado que corresponda a produzir de modo inequívoco e cujos sujeitos - educadores e educandos passem a se depararem com orientação e embasamento, no sentido de se conduzirem de modo compatível com os limites que garantam coerência das técnicas culturais com a condição orgânica do intercâmbio entre metabolismo humano e natureza livre, ao tempo em que se intensifica a situação sempre mais indireta que passou a caracterizar este intercâmbio.

Entrementes, tal proposição adentra desafio a se assemelhar com aquele da concepção do trabalho que, junto ao próprio Marx (2004, p. 109), veio a se expor a determinado paradoxo, ou seja, a ser tanto necessário quanto meramente tautológico qualificá-lo de 
produtivo, ou mesmo, a ser até absurdo reduzi-lo a improdutivo:

Só a tacanhez mental da burguesia, que tem por absoluta a forma capitalista de produção, e que, consequentemente, a considera forma natural da produção, pode confundir a questão do trabalho produtivo e do trabalhador produtivo do ponto de vista do capital, com a questão do trabalho produtivo em geral, contentando-se assim com a resposta tautológica de que é produtivo todo o trabalho que produz, em geral, ou que desemboca num produto, ou num valor de uso, em resumo: num resultado.

Inexistem dúvidas de que Lukács não logrou, ainda em vida, acessar esse ajuizamento marxiano, por força de que o texto em foco ainda permanecia inédito. De forma peculiarmente assemelhada, mesmo na atualidade histórica, ainda não é possível diferenciar entre caráter educativo da prática professoral e coerência docente com práxis educativo-coletiva, porque diferenciá-los depende de vir a ser proposto um objeto da própria educação. Assim, tal diferenciação passa a demandar insurgência de objetividade a pressupor critérios à toda prova, os quais facultem propor um objeto da própria educação, tendo-se em vista que este objeto condiciona o caráter da didática que é imprescindível para comunicá-lo. Trata-se de objeto que há de incidir no "em que" educar e, por isso, a concernente proposição 
chega a adentrar paradoxalidade quanto a jungir ousadia e modéstia.

Na busca de tais critérios, há como recorrer a determinada afirmativa, em cuja validação convergem Marx e, posteriormente, o próprio Lukács:

Nos Manuscritos econômico-filosóficos, Marx já considerava a relação do homem com a mulher a 'relação genérica natural'. Isso é correto e importante em sentido duplo. Por um lado, a base vital do gênero humano se realiza nessa relação de modo irrevogavelmente imediato; mas, por outro, tal relação, no curso do desenvolvimento da humanidade, se realiza sob as formas que a produção em sentido lato lhe imprime (LUKÁCS, 2012, p. 419).

A propósito desta afirmativa de Lukács (nisto admitindo-se eventuais restrições de tradução), cabe que se considere atentamente, não apenas o recurso de atribuir ação de sujeito, em vez de mera condição mediativa à "produção em sentido lato", além de que, conforme anteriormente citado, também assim se considere "a perspectiva de um salto filosófico em direção a questões decisivas, como a da relação entre teoria e prática [práxis], ou sujeito e objeto" [mediação]. São considerações que conduzem à eventualidade de existirem poros, fissuras, quiçá brechas, para vislumbrar como propor, ao menos isto, algo sobre "em que" educar e, em decorrência, também propor 
determinada categorização da práxis oriunda de Lukács e, através deste filósofo, também de Marx.

Então, de forma ulteriormente categorizada, passa a ser possível propor determinada práxis educativo-coletiva, dado que existe algo de "em que" educar a respeito da interação entre adulto(a) e prole ainda imatura, o que ocorre, antes de tudo, enquanto base física ou ôntica desta mesma interação que, sempre e originariamente, se processa entre sustentador(es) e prole ainda naturalmente autoinsustentável, enquanto os limitados efeitos da efetividade da interação em foco urgem passar a ser condicionantes da vigência dessa mesma práxis nos níveis acentuadamente mais complexos da relação entre mestre e aprendiz.

Além disso, trata-se da interação que provém de atitudes de sujeitos que, em coerência com a condição orgânica do intercâmbio sempre mais indireto entre metabolismo humano e natureza livre, apelam a técnicas culturais para intensificar a indiretitude mediativa desse mesmo intercâmbio, indiretitude esta já planetária e a difundir-se a partir das mais influentes metrópoles. Trata-se de coerência a coincidir com objetividade, ou seja, com algo cuja verdade se constata somente enquanto realidade pós-ocorrida, efetiva ou pronta. Além de que, no complexo dessa interação, sujeitos coexistem com mediações e objetos.

Os componentes dessa interação adentram ineliminável condição física ou ôntica de existência, o que significa que eles se constituem em "referência 'e' fundamento"

6 O conectivo " $\mathrm{e}$ " significa que subsiste incontinuidade, esta também ôntica, por entre ideias que sejam totalmente claras; antes de tudo o mais, coloca-se a clareza da ideia que, 
Referência é coincidente com orientação, servindo, assim, para pensar a respeito de em que se constitui a realidade da reprodução humana, cuja falta de sustentação - falta esta enquanto nada além do que hipotética - incidiria no (obviamente assim hipotético) absurdo da extinção da totalidade humana. Já fundamento, a significar também base ou suporte, serve de apoio seguro para agir em acordo com esta mesma reprodução.

À referência e à base do complexo correspondente à interação em foco, práxis educativo-coletiva adentra veracidade procedimental para professor pensar e agir no âmbito da relação entre aprendizagem e ensino. Aprendizagem prepondera sobre ensino, isto enquanto estrita questão de sentido, pois seria absurdo ela não acontecer, ao passo que ensino detém a presunção de ser universalizável, mesmo que esteja a ocorrer alheadamente à necessidade também pessoal de serem universalmente acessados os pertinentes objetos, bem como à objetividade propriamente física ou ôntica dos teores que compõem tais objetos.

Para ao menos amenizar tal alheamento, presume-se objeto educacional a ainda ser projetado e constituído, mediante determinada pesquisa-ação, em cuja processualidade seja possível integrar sujeitos "pesquisa-ativos" tão numerosos quanto o possível, para que os respectivos empenhos venham a acontecer com sempre mais intensa qualidade que decorra de achados de pesquisa cuja universalidade e multiplicidade de contribuições atendam àquelas referência e fundamento, conforme citadas

de forma radicalmente reflexiva, corresponda a esta mesma incontinuidade. 
anteriormente. Trata-se de empenho cuja efetivação tem adentrado incerteza quanto a ser ao menos relativizada mediante autoconvencimento, este a toda prova, para abraçar o sentido propriamente humano ainda obscuro na sociabilidade.

\section{Questão de Autoconvencimento a Toda Prova}

Práxis educativo-coletiva precisa se apresentar com prerrogativas sui generis para ser convincente e, inclusive, animar autoconvencimento a respeito de determinado desalheamento à objetividade - à onticidade - no âmbito atual da relação recíproca entre ensino e aprendizagem. Para tanto, esta práxis cumpre acontecer, primordialmente, no processo de formação de professores e, em decorrência desta primordialidade, possibilitar que se intensifique qualidade que contemple mudança no âmago do vigente processo educacional, pois este processo se encontra implicado na complexidade que é própria daquele inserido na sociabilidade humana, cuja mudança, segundo Lukács (apud Tertulian, 2010, p. 396, grifo nosso), depende das pessoas e adentra "caráter eminentemente casual" ao seu final:

A tese de fundo é que os processos sociais são postos em movimento exclusivamente através dos atos teleológicos dos indivíduos, mas a totalização desses atos numa resultante final tem um caráter eminentemente casual, privado de qualquer caráter finalístico. 
À luz dos teores da tese em foco, cumpre reconsiderar mudança do processo educacional na perspectiva de que esta mesma mudança venha a ocorrer enquanto suplementar ao "caráter eminentemente casual". Trata-se de suplementaridade, esta a ser restantemente assegurada, cuja pretendida efetivação não está a ser aventada enquanto de antemão descartável. Está, sim, a ser colocada em razão de que se inaugure autoconvencimento junto à docência na perspectiva de mudar a prática educativa tradicionalmente eivada de desfrute de poder no âmbito da relação ensino-aprendizagem e vice-versa.

No encalço de lograr tal autoconvencimento, bem como de prevenir que suplementaridade de mudança continue a ser vítima de descaso educativo, há como propor, ao menos isto, que se aprofunde a sondagem de elementos, a tanto propícios, no âmbito da realidade compreendida pela interação humana entre sustentador(es) e prole naturalmente ainda autoinsustentável, conforme procedimento acima já seguido, com efeitos não só de antemão buscados, mas, inclusive, surpreendentes do ponto de vista da pesquisa-ação em andamento.

Por sua vez, a efetivação de tal aprofundamento implica que se recorra ao sentido e à ausência deste mesmo sentido, um e outra, referenciados e fundamentados na onticidade que é própria dos componentes da interação em foco.

Assim, este sentido coincide com a procedência das ideias que dizem respeito a estes mesmos componentes, uma vez que esta procedência os faz deter extrema importância na perspectiva de que contribuam para a mudança de nada mais nada menos do que o processo cultural-civilizatório. Já ausência desse mesmo sentido - absurdidade, 
em rigor - coincide com a esquisitice de que a realidade provinda da reprodução humana ao longo desse mesmo processo tenha desandado em inconfessa indecência.

Por seu turno, esta indecência se tem constituído como abscôndita desculpa para a condição humana se desvelar simultaneamente explorada e exploradora dela mesma, além de restar radicalmente alheada e sempre mais impotente quanto às ideias decorrentes de buscar mudança de escopo limitadamente compatível com ético-cientificidade em desenvolvimento propriamente humano.

Entretanto, o escopo da mudança assim buscada se implica em desafio cujo enfrentamento ainda se encontra à espera de ser abraçado por indivíduos-sujeitos e apenas por estes, em acordo com o teor grifado na citação de Tertulian (2010) logo acima apresentada. Por sua vez, tais indivíduos precisam que se lhes deparem razões, necessárias e suficientes, para chegar a indispensável autoconvencimento.

Quanto à possibilidade de uma inicial colocação das razões em foco, recorre-se, ainda que de forma modesta e ousada, a um complexo de realidades, ao qual corresponda outro de concernentes concepções, ambos tendo que satisfazer à incomum criteriosidade de conter componentes que sejam óbvia, imediata ou prontamente entendíveis, conforme o que passa a ser proposto, logo a seguir, mediante quatro (4) componentes tidos como assim criteriosos:

$\left(1^{\circ}\right)$ aporte de saberes, estes a deterem validade, à qual nenhum ente humano há de eximir-se de acessar tais saberes, a bem de este ente reunir imprescindíveis condições para se ajuizar culturalmente adulto; 
$\left(2^{\circ}\right)$ dado este ajuizamento, acesso se torna imprescindível junto a educadores, mais do que junto a todos os demais adultos;

$\left(3^{\circ}\right)$ saberes cuja origem lhes faculte se imporem por eles mesmos, dispensando personalismos para serem difundidos, inclusive por deterem inequívoco caráter público, comum, universal e genérico; $\mathrm{e}$,

$\left(4^{\circ}\right)$ por força dos três (3) componentes anteriores e deste (ora enfocado) quanto a todos terem que estar sempre expostos a questionamento a respeito de serem inclusive incabíveis, incluindo-se, nesta condição, até mesmo as concernentes necessidades de existir.

À conta do caráter incomum atribuído a tal criteriosidade, remonta-se outra vez à referência (orientação) e ao fundamento (embasamento), ambos agora assumíveis como paradigmáticos, para retomar a categorização ulterior da práxis de origem marxiano-lukacsiana.

Trata-se de apelar a uma fértil e não menos paradigmática "mina de saberes", cujo mais intenso sentido de referência e fundamento reside naquela mesma interação entre sustentador(es) e prole naturalmente ainda autoinsustentável.

Já este apelo, anteriormente já ocorrido no contexto investigativo de determinada pesquisa-ação ${ }^{7}$, passa a se

7 Este contexto pesquisa-ativo originou-se a partir de determinada problematização, segundo BERGAMO (2012), seguida por uma tese circunstancialmente resolutiva da problematização em foco, conforme LUCENA (2015). Ambas - esta tese e aquela problematização - contaram com achados de pesquisa provindos daquele mesmo contexto, mediante estudos e pesquisas realizados, não apenas na Faculdade de Educação da Universidade Estadual de Campinas (FE-UNICAMP), 
deparar com oportunidade mais condizente com seu já promissor passado, mediante conveniada associação com o Programa de Pós-Graduação Profissional em Formação de Professores (PPGPFP) da Universidade Estadual da Paraíba (UEPB), campus de Campina Grande.

Trata-se de associação em cuja esfera cumpre que se busquem novos achados de pesquisa-ação, mediante um (já antevisto) aprimoramento do escopo teleológico da metodologia em seguimento, assim como de reflexões ainda mais extensas e aprofundadas sobre práticas de ensino, a começar por aquelas do próprio nível de pós-graduação e, a partir deste nível, desdobrando-se junto àqueles que o precedem e nos quais professores já formados cumprem enxergar e promover sucessores ainda em potencial.

Para efeito de intensificar aquele autoconvencimento, tal apelo precisa voltar-se para explicitar outras realidades e pertinentes idealizações, explicitação que ainda se encontra na condição meramente potencial de desvelar uma segunda ordem de realidades, estas enquanto componentes da realidade complexamente mais abrangente, ou seja, cumpre que se retorne ao marco inicial de tudo o que possibilitou encontrar a "mina de saberes" que ora se torna imprescindível para a educação lograr desalhear-se

mas também junto ao Grupo de Pesquisa-Ação CONSER (ser junto), institucionalizado na esfera político-institucional da Faculdade São Francisco de Barreiras (FASB) e a estar condicionado a "correr por fora" da político-institucionalidade dos Diretórios de Grupos do CNPq/CAPES. Tais achados lograram ascender a status político-institucionalmente formal, a partir da constituição do Grupo de Pesquisa-Ação Formação de Professores e Práxis Educativo-Coletiva. 
em relação à própria objetividade e a se encontrar exposta a ser mediada por violência e, desta, ser até mesmo reprodutora (COSTA; BERGAMO; LUCENA, 2016).

Nesta perspectiva, urge (re)enxergar e (re)examinar potenciais de novos conteúdos, objetos ou matérias educacionais, a partir daquela radicalmente mais referencial e fundamental da interação entre sustentador(es) e prole naturalmente ainda autoinsustentável.

Assim, emerge oportunidade de realizar quatro (4) dentre esses potenciais, à base das seguintes (sub)realidades e referentes (sub)concepções (novos objetos de saber), de forma que estas (sub)concepções reflitam condição ôntica de existência e aquelas (sub)realidades se caracterizem por deter esta mesma condição. Por isso, (sub)realidades e respectivas (sub)concepções têm como se desvelar (auto)convincentes:

A primeira coincide com determinada excedência de produção de pertença cultural e socialmente indefesa junto aos inequívocos destinatários. Trata-se de óbvia, imediata e prontamente inteligível existência de um excesso de produtos cujos destinatários - crianças e imprescindíveis meios de estas serem sustentadas - sequer têm como saber que esse excedente lhes pertence. Todavia, tem sido também assim inteligível, de forma óbvia, imediata ou pronta, que a concernente destinação tenha acontecido, em primeira e última instância, no âmbito da afetividade, âmbito, em cujo exterior, não tem sido possível criar político-institucionalidade para a devida destinação.

Paralelamente a tal problema de destinação, cumpre que se incida em dever peculiarmente moral, tornando-se a tanto elucidativo o fato de que, contra este mesmo problema, tem sido possível contar tão somente com a 
afetividade, conforme concernentes análises de Piaget (apud TAILLE, 1992, p. 70):

[...] nas suas análises, vemos afeto e moral se conjugarem em harmonia: o sujeito autônomo não é um 'reprimido', mas sim um homem livre, pois livremente convencido de que o respeito mútuo é bom e legítimo. Tal liberdade lhe vem de sua Razão, e sua afetividade 'adere' espontaneamente a seus ditames [da Razão].

\begin{abstract}
A segunda dessas (sub)realidades reside na separação entre um produzir e um apropriar os (sempre envolvidos) resultados. Trata-se de separação que faz com que ambos tenham que deter as respectivas identidades, diversamente de outras acepções de um e de outro, acepções que soem ocorrer imbricadas por conta de incidir na acumulação de patrimônio de maneira inseparável de conquistar poder ou vice-versa. Contra estas acepções, aquelas identidades e correspondentes idealizações têm como ocorrer, não apenas assim totalmente distintas, claras e precisas, como também mediadas por inegável moralidade que é seguida de modo espontâneo e de forma ainda irreflexa. Ao se falar de resultados sempre envolvidos naquela interação, consideram-se, não apenas cuidados e meios sustentatórios, como também afeto que é oferecido por adulto e apropriado pela prole naturalmente ainda autoinsustentável.
\end{abstract}


A terceira das (sub)realidades em apreço é pluralmente constituída como limites, estes referenciados mediante três perspectivas:

a) apropriação dos resultados: (a.1) junto a quem só produz, ao não apropriar uma parte dos resultados; e (a.2) junto a quem somente apropria esta parte;

b) ser naturalmente inevitável que todo resultado da produção ocorre limitado por existir enquanto fenômeno, ou seja, no interior das próprias aparências; e

c) a produção acontece mediante racionalidade a governar o processo de ela ser obtida, ou seja, à base do critério de que seus resultados não devem faltar nem serem desperdiçados por sobrarem.

A quarta (sub)realidade - esta a encontrar-se apenas indiretamente observável - corresponde ao sentido do modo ôntico, inconfundível com a forma ontológica, do que é inequivocamente coletivo, ou seja, aquele que corresponde ao grupal-natural mínimo, dado que se trata das condições de este coletivo acontecer consentaneamente com as condições nas quais ele surge, é mantido e tem que existir. Tais condições se colocam a partir daquelas que se implicam na existência das proles humanas naturalmente ainda autoinsustentáveis, à medida que estas proles não surgem e não se mantêm à própria conta, mas têm que existir. Trata-se de sentido que urge ser enxergado e concebido por além desse grupal-natural mínimo, porque a concernente existência (onticidade) perfaz fundamento também natural da pertinente institucionalidade (formalidade), para que sejam ultrapassadas as irregularidades nas quais incidem o que tem sido propriamente social, 
bem como as insuficiências do Estado enquanto ainda inescapavelmente sócio-institucional.

Uma vez atingido este patamar de encadeadas (sub) realidades e referentes (sub)concepções, coloca-se o potencial de que a pertinente e complexa conjunção adentre validade que é de antemão convincente a respeito de ser possível propor alternativa à inexistência de produção que fosse compatível com o que também anteriormente foi abordado sobre a marxiana "relação genérica natural", diversamente de o fazer mediante um coletivo grupal-natural mínimo.

Trata-se de alternativa na qual se constata que a interação entre sustentador(es) e prole naturalmente ainda autoinsustentável acontece enquanto modo inequivocamente coletivo da existência humana, tanto plural (comunidade) quanto singular (grupal-natural mínimo), tornando-se convencível que eventual falha humana no âmbito desta interação acontece de modo inegavelmente individualista, podendo ser até mesmo fatal à singularidade deste ou daquele modo de existir grupal-natural mínimo, ao passo que nunca chegou a ser fatal na pluralidade das existências singulares desse mesmo coletivo, embora admitir probabilidade zero de ocorrer fatalidade assim global adentre projeção ilimitada do pensar e, por isso, se expõe a ser mítica.

Tal convencibilidade se torna plausível, ao incorrer na diferença categorial entre o inequívoco sentido do que é coletivo (realidade ôntica presente na interação em foco) e a prevalência do individualismo (questão antes etnográfica do que genericamente humana, além de possivelmente estar mediada por machismo) na "relação genérica natural" colocada por Marx. 
Dada tal diferença, intensifica-se suspeição quanto a existir poro, fissura ou mesmo brecha para propor, não apenas ulterioridade de categorização ao que Marx denomina "genérico natural", como também a inegável existência de determinada regulação da economia cuja necessidade chegou a ser apontada pelo próprio Marx (apud LUKÁCS, 2012, p. 419), à base de: “[...] uma racionalidade economicamente ótima na regulação do desenvolvimento econômico, mas também de que essa regulação se realiza 'nas condições mais adequadas à sua natureza humana e mais dignas dela'".

Já esta economia sempre se encontrou, ao menos vislumbrável, na ocorrência pluralmente constituída daquela "interação entre sustentador(es) e prole naturalmente ainda autoinsustentável" ${ }^{8}$. Trata-se de abordagem da economia, peculiarmente alternativa a outras já vigentes e ditas orto-heterodoxas. Assim alternativa, conquanto ainda não mais do que proposta a se constituir em conjunção entre ética e ciência, tal economia se escuda na referencial-fundamentalidade dessa mesma interação. Por isso, reúne condições para inibir equivocação e desinibir veracidade do que precisa significar produção que tem sido tão somente produção (junto a gerador de determinado excedente que não lhe pertence) e apropriação que

8 Um vislumbre sobre o conteúdo da economia em foco logrou ser explicitado junto ao (acima já referido) Grupo de PesquisaAção CONSER-FASB. O conteúdo assim vislumbrado passou a ser difundido mediante o título de "Economia Propedêutica e Interdisciplinar", cujo saber veio a ser assumido como paradigmático na realização da Proposta Pedagógica Fasbiana (PPF) que também foi educativo-coletivamente concebida junto a esse mesmo Grupo. 
é estritamente apropriação (junto ao que perfaz inequívoco sentido coletivo, a começar pela sustentação da prole naturalmente ainda autoinsustentável).

Por sua vez, a veracidade em foco coincide com a procedência das idealizações correspondentes àquelas quatro (sub)realidades, uma vez que esta procedência faz com que tais idealizações detenham extrema importância na perspectiva de que contribuam para a anteriormente apresentada mudança do processo cultural-civilizatório. Já a falta da procedência em foco tem incidido em absurdidade, ao coincidir com a acima mencionada esquisitice de que a realidade a provir da reprodução humana, ao longo desse mesmo processo, tenha adentrado até mesmo indecência.

Trata-se, então, de retomar a condição objetivada da existência de saberes, em razão de estes deterem potencial para, de uma parte, referenciar coerência na mediação sempre mais indireta que está a caracterizar o intercâmbio orgânico entre metabolismo humano e natureza livre, e, de outra parte, fundamentar mudança inerentemente a processos sociais, pois, tal mudança depende de teleologizações que acontecem na esfera estritamente individual e que precisam ocorrer no sentido de que também se chegue àquela suplementaridade do "caráter eminentemente casual" da (acima citada) tese lukacsiana.

\section{Priorização do "em que" Educar}

Ao se ter em vista a atual necessidade de uma regulação voltada para intervir no processo educacional e que venha a ser efetivada em condições mais dignas da natureza humana, a abordagem da educação até este ponto 
desenvolvida tem recorrido a teores inusitadamente estranhos em relação àqueles que têm sido tradicionalmente acessados na própria formação dos professores.

Trata-se de estranheza que tem a ver, tanto com identificar quanto com propor os teores em foco, pois estes se distinguem em razão do que lhes é mais referencial e fundamental, ou seja, enquanto orientativos e embasadores. Nesta condição, eles existem, não apenas enquanto ônticos e formais, como também de modo comum, genérico ou universal. Por isso, precisam ser prioritariamente acessados por educadores que irão promover tal acesso junto aos educandos.

Na perspectiva de assim serem acessados, cumpre que tais saberes sejam propostos, não apenas por força da condição na qual eles existem, mas também e sobremaneira, por se implicarem em priorizar o "em que" educar.

Por sua vez, tal priorização há de confrontar a usual predominância do devotamento à didática e sua instrumentalização, mesmo que ambas ainda não deixem de ser necessárias e restem carentes de intensificação das concernentes qualidades para continuarem a compor a mediação do processo educacional; todavia, esta mediação não lhes faculta lograrem predominância, para não dizer, monopolismo, enquanto forma pela qual se processa a educação.

Por outra parte, objetos educacionais têm sido tão numerosos e diversos que as concernentes identidades se tornaram antes problema do que solução, o que justifica levantar a questão de uma criteriosidade para determiná-los na perspectiva de compor os usuais currículos de ensino.

Aquela estranheza de teores, bem como essa priorização do "em que" educar, além da questão de criteriosidade 
em identificar aqueles objetos, todas foram precedidas pela conjunção de dois indissociáveis complexos de teores, um destes enquanto realidades (onticidades) e o outro enquanto concepções (formalidades).

Entrementes, tornou-se comprovável que a conjunção desses complexos compreende potenciais cujas efetivações coincidem com uma já inegável "mina de saberes". Por sua vez, esta "mina" se expõe a ser experimentada, à medida que tais potenciais sejam efetivados, e, a seguir, representados. Trata-se de coincidência que significa engendrar saberes que, alternativamente, seriam pouco ou nada identificáveis e raramente reconhecíveis como procedentes.

Dentre estes saberes merece destaque a reafirmação daquela criteriosidade, à qual se recorre para justificar estranheza de teores sobre "em que" educar, bem como considerar dominantes, ao longo da história do processo educacional, a didática e a sua instrumentalização.

Esta predominância, entretanto, não tem sido enxergada enquanto reflexo de alheamento à mediação da violência que, ao longo da história da humanidade, passou a se implicar, não apenas em equivocação e em inibição a propósito da veracidade sobre o que seja produzir antes de tudo conhecimento, como também em irreflexa e forçosa efetivação desta veracidade junto a pessoas que se encontram objetivamente menos defesas, ou seja, junto a recorrentes vítimas das "injustiçações" ${ }^{\text {"9 }}$ políticas, econômicas e, reflexamente, educacionais.

9 Neologismo que reúne injustiça à ação que a promove, o qual prevalece no contexto do Grupo de Pesquisa-Ação 
Então, no encalço de propor desalheamento à mediação da violência, à base da alternatividade dos teores da educação até este ponto apresentados, coloca-se aquela veracidade sobre produzir.

Por sua vez, tal veracidade sempre existiu, enquanto situadamente distante em relação àquela mediada por violência. Nesta circunstância, tal produção tem sido espontânea, além de coerente com reprodução humana mediada por equilíbrio no intercâmbio orgânico entre metabolismo humano e natureza livre.

Todavia, passou a existir apropriação que, ao longo da história e a título de trabalhar no âmbito das trocas, se restringe a nada mais do que parasitar a produção assim inequívoca, dado que a concernente e sempre mais indireta mediação daquele intercâmbio se tornou incoerente com esse mesmo metabolismo, a partir do esgotamento da condição direta das práticas de escambo. Trata-se de mediação, cujo caráter indireto está recorrentemente propenso a incidir em mera criação de acréscimos nominalísticos aos valores de troca ("precificação") das utilidades, o que pressupõe a monopolização da própria troca.

$\mathrm{Na}$ abordagem de tal "precificação", cumpre aquilatar que desalheamento à mediação da violência se implica em que produzir, de forma inconfundível com apropriar, seja inibidor da equivocação e desinibidor da veracidade a respeito do que precisa significar produção assim inconfundível.

Após as considerações colocadas até este ponto sob o título de "priorização do 'em que' educar", torna-se

CONSER-FASB, conforme consta em Bergamo, Lucena e Santana (2017, p. 12). 
plausível que a mais antiga e menos categorizável como propriamente educação já estivesse presente nas mais remotas origens da produção de grãos e da criação de animais domesticáveis, tal como o caso de uma comunidade que existiu no Oriente Médio, ou mais precisamente, na bacia do Rio Jordão e nas adjacências da atual cidade de Jericó. Nestas origens, o aprendizado era constituído por acesso direto a realidades radicalmente ônticas e as concernentes formalidades já facultavam trocas.

Sobre esta produção, conforme Barraclough (1995, p. 40), achados arqueológicos confirmam avanço civilizatório:

Tigelas de pedra serviam como recipientes, e, da obsediana, vidro vulcânico vindo da atual Turquia, eram feitos objetos cortantes. Fornos de argila eram usados na cozinha. Existiam edifícios públicos e santuários, alguns contendo estátuas de gesso.

Posteriormente, emergiu a educação junto à nação fenícia, originária das adjacências do hoje chamado Mar Vermelho, mas que se tornou historicamente mais reconhecida após migrar para as costas orientais do Mar Mediterrâneo e neste mar se fazer presente até o ano 146 a.C., ano da destruição de Cartago por prepostos do Império Romano.

Sabe-se que os fenícios chegaram a dominar o alfabeto, os números e já adotavam o procedimento mecânico de 
resolver um problema, o qual se originou na atual Índia e hoje é chamado de algoritmo.

Entre os fenícios, a educação e a vivência da produção, peculiarmente a produção artesanal, nunca se separaram, embora, nos últimos séculos da existência desse povo, artes marciais para meninos tivessem chegado a ser incluídas por além das tradicionais de uma nação devotada ao comércio e à navegação.

Por seu turno, as artes marciais na condição de objeto de ensino e de aprendizagem já indicam o processo educacional que sucedeu aquele de origem mais antiga e de acesso direto às atividades propriamente produtivas e às pertinentes idealizações. Segundo Aristóteles (2007, p. 98): “[...] as leis antigas eram excessivamente simples e bárbaras: os helenos andavam sempre armados e compravam as esposas uns dos outros".

Diversamente, aprender a produzir deteve sorte aparentemente autodidata: "[...] foi com razão que Hesíodo disse que a primeira família foi composta 'pela mulher e o boi feito para o labor, pois o boi exerce o papel do escravo entre os pobres'" (ARISTÓTELES, 2007, p. 55).

Mas, foi junto a prepostos do Império Persa que esse novo processo veio a decantar-se, mediante discriminação entre os gêneros da espécie, pois os meninos eram separados dos pais desde os seis anos de idade e entregues a senhores já idosos e da inteira confiança do governante máximo para se tornarem futuros soldados do Império.

Este perfil do processo educacional, com diferenças pouco relevantes, perdurou até a Antiguidade Clássica ${ }^{10}$

10 Esta Antiguidade se iniciou por volta do séc. VI a.C, com o fim da paideia arcaica que "[...] consistia na educação dos 
e se fazia presente por força de que, em terra firme, agressão se tornara defesa preventiva e, nesta condição, adquiriu caráter estrutural. Assim e com a descaracterização da educação fenícia que precedera aquela vigente ao longo da dominação de Cartago, violência passou a mediar a educação na Ásia Menor e na Europa mediterrânea, o que coincidiu com a condição secundária da presença de meninos no contexto mais humanamente qualificante da produção, como também da ausência de meninas naquele mais desumanamente decisivo da reprodução da violência.

$\mathrm{Na}$ história mais recente, ou seja, após a Revolução Industrial, violência na escola passou a ser mais sutil, mas não menos cruel, pois veio a decorrer de acesso ao saber acentuadamente mais abstrato com mais prolongada presença na própria escola e, posteriormente a esta presença, exposição dos jovens de ambos os gêneros à intensificada dificuldade quanto a deparar oportunidade ocupacional que corresponda ao domínio do saber abstrato anteriormente já acessado.

A partir da vigência conjunta da sutilidade e da crueldade a decorrerem da escolarização dos jovens, a questão de gênero de aprendizes veio a se tornar sempre mais irrelevante em relação ao acesso ao mundo do trabalho.

filhos dos senhores nobres e proprietários [...]", sendo "voltada exclusivamente para a educação dos meninos (...). Nesta paideia, se destacava o "professor de educação física ou pedotriba, uma espécie de instrutor de atividades marciais e militares. Ensinava lutas corporais, equitação, natação e preparava as crianças (meninos) para as lutas e os jovens aos exercícios militares e futuros trunfos nos jogos olímpicos" (NUNES, 2009, p. 157 e 158). 
Já esta irrelevância passa a ser intensificada, devido à também intensificada mediação da tecnologia, pois esta mediação está a se implicar em mudanças que se desvelam na inteiridade do processo social.

Entretanto, esta mesma mediação adentra intensidade que se move paralelamente àquela do poder na relação entre ensino e aprendizagem. Por isso, as mudanças em foco não ocorrem isentas de coadunação com as desigualdades políticas, pois estas se colocam como supramediadoras dos desníveis educacionais, enquanto um implícito ordenamento, desvelável à conta destes desníveis e daquelas desigualdades, se implica nas disparidades econômicas. Já estas disparidades se tornam básicas, por força de se coadunarem com a sustentação propriamente material das condições sócio-redistributivas de poder e da própria educação, esta enquanto ideologismo que se impõe à total revelia da ético-cientificidade anteriormente definida como a (sub)realidade e a pertinente (sub)concepção a respeito de limites, a serem engendrados a partir da realidade e da sua concepção, ambas a incidirem na interação entre sustentador(es) e prole naturalmente ainda autoinsustentável.

Por seu turno, tal supramediação e implícito ordenamento adentram caráter mistificante, enquanto projeções ilimitadas do pensar humano. Diz-se mistificante por força de que é um equívoco atribuir causalidade à mediação, pois significa excluir a própria mediação da sua existência enquanto ôntica e formal, existência que é substituída pela invisível necessidade ou pelo vazio dela mesma.

Trata-se de mistificação cuja origem se confunde com aquela do Estado, desde que esta origem tenha coincidido com aquela que, possivelmente, se originou no 
atual Egito, ou mais precisamente, no Egito que é descrito como aquele do Alto Nilo já ao final do quarto milênio (a.C.). Neste espaço socioeconômico, a produção de meios de vida, nas margens recorrentemente fertilizadas por enchentes, sempre se expusera a incursões de povos dos desertos circundantes. Estes povos enfrentavam o dilema de assaltar ou perecer, além de ignorarem o que significava cultivar terras e criar animais. Aí, no Alto Nilo, a defesa veio a ser empreendida de modo enfim sistemático, mediante a constituição de contingentes de homens a se dedicarem, presumidamente, a defender a produção. Os usuais comandantes destes contingentes descobriram as três circunstâncias que mais lhes acarretavam poder:

$\left(1^{a}\right)$ contar com excedentes sustentatórios sem participar da concernente e direta obtenção;

$\left(2^{a}\right)$ agredir, enquanto defender-se preventivamente, era-lhes estrategicamente preferível a serem surpreendidos;

$\left(3^{a}\right)$ difundir estas duas descobertas convinha ocorrer até mesmo no Delta do Nilo, uma espécie de paraíso que sempre se expusera a conquistas de povos mais ameaçadores do que os habitantes dos desertos a oeste e a leste.

Assim, essas três descobertas de guerreiros foram aplicadas enquanto conquista de outro reino, então também existente no Delta do Nilo, pelo rei do Alto Nilo que, obviamente, era mais afeito à importância de tudo o que lhe acarretava poder. Esta conquista ocorreu por volta de 3.100 (a.C.) e tem como assinalar existência já possível do Estado, este, então, também difundível na Ásia Menor e nas terras adjacentes ao mar Mediterrâneo, tal como possivelmente existira no Egito ainda mais antigo. 
Mesmo que não se concorde com tal origem do Estado, sabe-se que é inegável que ela sempre coincidiu com acesso a recursos cuja obtenção e uso pouco ou nada diferem de dispor de tributos provindos enquanto resultados da produção, os quais têm sido inegavelmente tomados mediante violência.

Prevenir exposição à violência passou a se implicar em promover a própria violência, de modo imprescindível inclusive, para que o preposto daquela prevenção e desta promoção convivesse com a inevitável reprodução do poder cuja perda sempre incidiu em ameaça, ou, alternativamente, ter havido violência para preposto do poder emergir, ou seja, para alguém se dispor a recorrer, preventivamente, a meios de violência e tal recurso significar a própria origem do Estado.

Trata-se de origem que ocorreu, até necessariamente, em indeterminadas circunstâncias do passado histórico e ainda se reproduz à base de inevitabilidade de se promover violência (tributação) e, deste modo, tem emergido o paradoxo de tal promoção se explicar à conta de nada mais do que a sua própria existência.

Violência é incompatível com afeto. A educação sem afeto tem tido as artes marciais como parte, ao menos esta, do seu currículo que lhe é existencialmente característico. Todavia, a educação de crianças se tornou questão de cuidado que, por sua vez, detém existência mais procedente ao incidir em afeto do que o deteria caso se originasse mediada por violência.

Crianças e adolescentes têm de contar com cuidados, mas há casos, inclusive muito frequentes, de terem tido que padecer falta, não apenas de cuidados, mas inclusive de afeto devidamente oportuno. Por isso, profissionais da 
educação precisariam suprir eventual falta de cuidados por afeto mais intenso do que o usual, gesto a equivaler com peculiarmente generoso excedente de produção que seja destinado a jovens que incorrem em insuficiência de aprendizagem, ou mesmo não aprendem, em decorrência de uma falta de oportuno cuidado e/ou de afeto, falta já ocorrida até mesmo desde o nascimento e a persistir no exterior da escola. Por outra parte, cabe ser admitida a presença na escola de crianças que sempre tenham recebido muitos cuidados e/ou afeto, o que poderia atrair demasiada atenção de professores e estes destinarem cuidados e/ou afeto, inclusive em excesso, ou seja, em prejuízo de outras que mais careçam deles.

De toda forma, cuidados e/ou afeto perfazem a inteiridade do socialmente mediado processo da educação. Adentram o "em que" educar que precisa se fazer presente enquanto referência e fundamento e, mediante os quais, também se faça presente criteriosidade para que esse processo venha a preservar o sentido de ele mesmo existir. Trata-se de existência que ocorre na condição de ser a mais relevante e qualificada fonte de todos os demais sentidos no âmbito da globalidade do processo social que jamais deixou de apresentar-se carente de mudança.

\section{Considerações Finais}

Profissionais da educação, somente eles, são responsáveis pela possibilidade de induzir determinada e efetivável mudança inerentemente a processos sociais, além de que, se eles não assumirem tal indução, mudança alguma irá acontecer no âmbito de tais processos. 
Para tanto, conforme anteriormente abordado, cumprirá que se convençam da universalidade ou da generidade da conjunção de dois indissociáveis complexos de conteúdos; um deles é composto por realidades (matérias) e outro por representações (concepções) concernentes a estas mesmas realidades. Trata-se de conjunção que sempre se expôs a ser convertida em teor educacional, em razão de que as matérias são ônticas e as concepções são propriamente formais ou ontológicas.

São conteúdos cujo acesso sempre foi imprescindível junto a todo educador, pois, se este continuar alheado a esta imprescindibilidade, expõe-se a crescente risco de ser por eles inclusive atropelado.

A principal característica desses conteúdos reside em que eles têm como corresponder a "em que" educar e, por isso, adentram peculiar estranheza na perspectiva de virem a incidir em teores propriamente educativos. Por sua vez, tal estranheza tem decorrido de que o "como" educar - a didática - tem sido sempre mais intensamente dominante na relação entre ensino e aprendizagem das meras abstrações nas quais se constituem os conteúdos ora até imperativos. Trata-se de dominância que urge ser questionada à medida que se intensifica a suspeita de que as abstrações em foco tendem a retardar que venha a prevalecer o caráter propriamente formal daquelas concepções, ou seja, a condição abstrata dos teores de ensino se torna sempre mais dissociada, distanciada ou descaracterizada, em relação ao que ela mesma cumpre representar de forma procedente, precisa ou identificadora.

Tal descaracterização das abstrações se tem implicado em que um nível educacional anterior passe a ser requerido, de forma presumidamente propedêutica, para que 
venha a ser possível adentrar nível que seja superior ao acessado, sempre e sobremaneira mais recentemente. Já esta possibilidade tem acontecido com tendência de ser excludente, até chegar ao topo em que a falta de nível ainda mais superior induz a que os formados, pós-graduados lato ou stricto sensu, tenham que se ocupar com nada mais do que diversidade de formações, estas o quanto possível mais próximas do nível mais elevado.

Ocupar-se com a iniciação, ou mesmo, com a base da intensificação do caráter estritamente abstrato dos conteúdos ensinados e aprendidos, perfaz tendência a resultar em mister tão amplo, comum, ou mesmo inglório, quanto tende a resultar estreito, escasso, ou mesmo exaltado, ocupar-se com o término ou com o ápice dessas abstrações.

Este ápice e aquela base também estão a ocorrer com a intensificação de poder na relação entre ensino e aprendizagem. Sabe-se que esta relação é própria da esfera estatal e se desvela incompatível com a dinamização de cuidados e/ou do afeto no processo educativo. Reforça-se, desta forma, não só a urgência de priorizar o "em que" educar, como também a questão de criteriosidade em identificar objetos educacionais. Além disso, se professores não abraçarem tal dinamização, mudanças continuarão a acontecer, segundo o mero "mudar para nada mudar".

Enfim, aquela priorização e essa criteriosidade adentram, conjuntamente, problematização e hipótese de trabalho, a primeira a ser aprofundada e a segunda a ser desenvolvida na perspectiva de chegar a se constituir em premeditada tese, mas ambas a serem orientativas e embasadoras do Grupo de Pesquisa-Ação intitulado "Formação de Professores e Práxis Educativo-Coletiva", na perspectiva de que os teores do texto ora em conclusão 
signifiquem, eles mesmos, ensino, ou seja, coincidam com aquele de professores na formação de novos professores que venham a promover educação a adentrarem inequívoco sentido do que é coletivo. Em decorrência, seus egressos chegarão a perceber o que é propriamente público, de modo ético e de forma científica, em relação ao que historicamente se tem impingido como estatal.

\section{Referências}

ABBAGNANO, Nicola. Dicionário de filosofia. São Paulo: Martins Fontes, 2007.

ARISTÓTELES. Política. São Paulo: Martin Claret, 2007.

BARRACLOUGH, Geoffrey. Atlas da História do Mundo. São Paulo: Folha da Manhã, 1995.

BERGAMO, Pedro. Educação universitária: práxis coletiva em busca de veraz qualidade e de precisa cientificidade. Campina Grande, PB: EDUEPB, 2010.

BERGAMO, Pedro; LUCENA, Roberto Marden; SANTANA, José Neves. Economia: propedêutica e interdisciplinar. Barreiras-BA; CONSER-FASB, 2016, (mimeo.).

COSTA, Antonio Roberto Faustino da; BERGAMO, Pedro; LUCENA, Roberto Marden. A utopia em questão: desalheamento educacional à objetividade. In: SOUSA, Cidoval Morais de (Org.). Um convite à utopia. Campina Grande, PB: EDUEPB, 2016. p. 235-290. 
LUCENA, Roberto Marden. Educação superior, trabalho e humanização: mediações políticas e pressupostos institucionais para a análise da produção social e dos impactos do projeto de formação FASB - Barreiras-BA. Campinas, SP. 2015. Tese (doutorado) - Universidade Estadual de Campinas, Faculdade de Educação.

LUKÁCS, György. Prefácio (1967). In: Lukács, G. História e consciência de classe: estudos sobre a dialética marxista. São Paulo: Martins Fontes, 2003, p. 1-50.

LUKÁCS, György. Para uma ontologia do ser social I. São Paulo: Boitempo, 2012.

MARX, Karl. O capital. Capítulo IV inédito de O Capital, resultados do processo de produção imediata. São Paulo: Centauro, 2004.

NUNES, César. O pedotriba e a educação física antiga: o primeiro professor, a primeira paideia e o pecado original. Filosofia e Educação (Online), Campinas, SP, v. 1, n. Especial, p. 157-163, out. 2009. Disponível em: <https:/ / periodicos.sbu.unicamp.br/ojs/index.php/rfe/article/ view/8635557/3350>. Acesso em: 20 dez. 2016.

SAVIANI, Dermeval. Escola e democracia. Campinas, SP: Autores Associados, 2009.

SIMONDON, Gilbert. El modo de existencia de los objetos técnicos. Buenos Aires: Prometeo Libros, 2007.

TERTULIAN, Nicolas. Posfácio. In: LUKÁCS, György. Prolegômenos para uma ontologia do ser social. São Paulo: Boitempo, 2010. p. 383-402. 
TREVISAN, Marlon Dantas; GALINDO, Camila José. A complexidade da profissão docente: enfrentamentos necessários. Quaestio, Sorocaba, SP, v. 16, n. 2, p. 451468, nov. 2014. Disponível em: <http://periodicos.uniso. br/ojs/index.php/quaestio/article/view/2091/1824>. Acesso em: 15 jan. 2017. 



\title{
O PAPEL DA FORMAÇÃO DE PROFESSORES NO COMBATE AO SEXISMO EM SALA DE AULA NA EDUCAÇÃO INFANTIL
}

\author{
Arilane Florentino Félix de Azevêdo ${ }^{1}$ \\ Tânia Maria Augusto Pereira ${ }^{2}$ \\ - Pai... \\ - Hummmmm? \\ - Como é o feminino de sexo? \\ - O quê? \\ - O feminino de sexo. \\ - Não tem. \\ - Sexo não tem feminino? \\ - Não.
}

1 Mestre pelo Programa de Pós-Graduação em Formação de Professores da Universidade Estadual da Paraíba (UEPB). Pedagoga pela Universidade Federal da Paraíba (UFPB). Pesquisa sobre gênero e educação. É membro do Núcleo Interdisciplinar de Pesquisa e Ação sobre Mulher e Relações de Sexo e Gênero (NIPAM-UFPB). Atua como Tutora a Distância no Núcleo de Direitos Humanos da UFPB. E-mail: arilane_florentino@hotmail.com

2 Doutora em Linguística pela Universidade Federal da Paraíba (UFPB). Professora do Departamento de Letras e Artes e do Programa de Pós-Graduação em Formação de Professores da Universidade Estadual da Paraíba (UEPB), campus I, em Campina Grande-PB. Desenvolve e orienta pesquisas na área de Análise do Discurso, que contemplem a produção e circulação de diferentes discursos (midiático, publicitário e outros discursos do cotidiano) entrelaçados em uma rede dialógica de saber-poder, e sua influência nos saberes e práticas educacionais. E-mail: taniauepb@yahoo.com.br 
- Só tem sexo masculino?

- É. Quer dizer, não [...]

- Sexo é sempre masculino.

Extraído da crônica "Sexa" (VERISSIMO, 2001, p. 53-54)

\section{Comentários iniciais}

Vivemos em uma sociedade em que meninos e meninas, homens e mulheres compartilham de uma visão androcêntrica na qual foram educados(as) e que norteia seus pensamentos e ações. A visão sexista, de discriminação entre os sexos, é dominante em nossa sociedade e, por consequência, nas nossas escolas.

Ao chegarem à escola, as crianças já vem marcadas por diferentes fatores externos que lhes fizeram criar uma imagem de mundo, com base nos valores da sociedade androcêntrica a qual pertencem. A escola precisa intervir e não deixar seus alunos e alunas permanecerem com pensamentos tão limitados, a não intervenção seria apoiar o modelo androcêntrico socialmente divulgado. Rever velhos estereótipos e preconceitos desde a infância é a saída para um mundo mais igualitário.

Este artigo objetiva refletir sobre a construção de uma cultura sexista dentro da sala de aula na educação infantil e sobre os passos que podem ser seguidos para que se inicie um processo de desconstrução dessa cultura. Pretende contribuir para as discussões acerca do sexismo em sala de aula na educação infantil. Através de uma revisão da literatura sobre a temática abordada, buscaremos fazer uma reflexão sobre o papel que a escola cumpre na formação da consciência machista nas crianças, levando-as a se 
tornarem adultos agressores e na desconstrução do ciclo de opressão vivido pelas mulheres.

Para tanto, na primeira parte buscaremos fazer uma retrospectiva histórica do papel da mulher, desde as sociedades primitivas até a atualidade. Para isso, faremos um diálogo com Engels (2000), no que se refere à origem das relações sociais. Também faremos uma discussão sobre o sexismo e como ele se configura na educação infantil. $\mathrm{Na}$ segunda parte, discutiremos a formação docente, fazendo um recorte sobre essa formação na educação infantil. Para isso, teoricamente utilizaremos Ferreira (2014), Rocha (2012) e Oliveira (2013). Na terceira parte, refletiremos sobre o papel da formação de professores no combate ao sexismo em sala de aula da educação infantil. Por fim, faremos nossas conclusões a respeito da formação docente e a construção do sexismo em espaços educacionais tendo em vista que é necessário que os cursos de Licenciatura proponham mudanças nos currículos para que o professor da educação básica possa ter em sua formação disciplinas que abordem as questões de gênero e também, de forma transversal, a temática da sexualidade dentro das escolas.

\section{Desigualdade de gênero: um olhar pela história da mulher}

Nesta seção, buscamos trazer questões sobre a história da mulher que, muitas vezes, não são contadas. Vivemos em uma sociedade marcada por desigualdades sociais, políticas e econômicas. Nessa sociedade, busca-se fazer com que as pessoas acreditem que essas desigualdades sempre existiram e existirão, inclusive as desigualdades em torno da mulher. 
Sobre essa temática, Engels tece a seguinte reflexão:

Uma das ideias mais absurdas que nos transmitiu a filosofia do século XVIII é a de que na origem da sociedade a mulher foi escrava do homem. Entre todos os selvagens e em todas as tribos em que se encontram nas fases inferior, média e até (em parte) superior da barbárie a mulher não só é livre como, também, muito considerada (ENGELS, 2000, p. 51).

Segundo o autor, na origem da sociedade, a mulher não era explorada pelo homem, muito pelo contrário, seu papel era reconhecido dentro da sociedade. Então, como surgiu a desigualdade?

Tradicionalmente, quando uma família recebe um recém-nascido tem expectativas distintas. Se for um menino, ele é esperado com um enxoval no qual predomina a cor azul; se for uma menina, o enxoval é repleto da cor rosa. De um menino, espera-se que seja agressivo; da menina, espera-se que seja delicada. O conceito de gênero procura combater essa desigualdade pautada em aspectos biológicos para justificar diferenças.

Dentro das expectativas, os meninos são educados para serem corajosos e não terem medo de perigos, enquanto as meninas são educadas para serem delicadas e perfeitas. Espera-se que eles sejam "durões" ("menino não chora") e que elas sejam responsáveis pelo lar, pelos filhos e pelo esposo. 
Nessa perspectiva, ensina-se às crianças do sexo masculino a dominarem os sentimentos, não chorar, não demonstrar medo, porque eles serão interpretados como sinal de fraqueza e de insegurança, qualidades moralmente desqualificadas; e as do sexo feminino a serem afetuosas, solidárias, prestativas, despretensiosas, atitudes que o mundo do poder e da competição não valoriza.

Para falarmos do surgimento da desigualdade, precisamos falar primeiro do surgimento da propriedade privada. Em qualquer livro de História, ao falar do desenvolvimento das sociedades, observa-se que com esse desenvolvimento, os seres humanos vão tendo o domínio da criação do gado, da elaboração de utensílios de metais, da agricultura, entre outras. A mulher era responsável pelo trabalho doméstico e o homem pela agricultura e pelo pastoreio. O surgimento da propriedade privada vai tornar o gado e os produtos agrícolas principais fontes de riqueza da comunidade, propriedades dos homens. Sendo assim, surgiu um conflito entre a propriedade privada masculina e a organização social que tinha como base a linha matriarcal, já que nessa sociedade os homens não sabiam quais eram seus filhos legítimos, ou seja, eles não tinham como identificar seus herdeiros e, consequentemente, não tinham como garantir a sucessão de sua propriedade.

Sobre esse momento histórico, Engels considerou que, à medida que as riquezas iam aumentando, o homem adquiria uma posição mais importante do que a mulher na família e isso fazia "com que nascesse nele a ideia de valer-se desta vantagem para modificar, em proveito dos seus filhos, a ordem da herança estabelecida" (ENGELS, 2000, p. 59). 
Assim, o homem começou a querer quebrar a estrutura familiar vigente, com uma base matriarcal. A partir daí, a estrutura social passou a ter como alicerce o patriarcado. Com essa transição, a mulher passou a ser vista de outra forma dentro da sociedade. Concretizou-se o desmoronamento do direito materno e a derrota histórica do sexo feminino em todo o mundo. "O homem apoderou-se também da direção da casa; a mulher viu-se degradada, convertida em servidora, em escrava da luxúria do homem, em simples instrumento de reprodução" (ENGELS, 2000, p. 61).

Desse modo se iniciou a desigualdade social no mundo. E essa desigualdade, por sua vez, gerou vários problemas para a mulher, que passou a ser propriedade do homem. Essa reflexão nos conduz à discussão do próximo tópico sobre o sexismo.

Sexismo: conceito e origem

O sexismo se encontra presente na educação e no cotidiano através de algumas ações, seja por meio da linguagem, nos livros, nos gestos, que de maneira muito singular acabam por distanciar meninas e meninos, reforçando as diferenças e desfavorecendo a igualdade de gêneros. Os professores exercem um papel decisivo nessa questão quando colocam expectativas diferentes para meninos e meninas. Para as meninas, espera-se que elas sejam organizadas, meigas, atenciosas e comportadas. Nota-se essa situação até mesmo na linguagem usada pelos professores que tratam as meninas com meiguice e de forma mais amorosa. Já com relação aos meninos, eles serão sempre vistos como agitados, agressivos e bagunceiros. 
De acordo com Smigay (2002, p. 34), "sexismo é uma posição, ou uma postura misógena, de desprezo frente ao sexo oposto". É importante ressaltar que o sexismo pode ser exercido tanto por homens quanto por mulheres. Ainda sobre o sexismo, Smigay (2002, p. 34) apresenta a seguinte reflexão: "Inscrito numa cultura falocrática, impregna o imaginário social e o prepara a um vasto conjunto de representações socialmente partilhadas, de opiniões e de tendência a práticas que desprezam,desqualificam, desautorizam e violentam as mulheres".

Sobre a violência de gênero, Smigay $(2002$, p. 34) traz a seguinte reflexão "a violência de gênero está enraizada de forma profunda e persistente na trama social, o que a torna uma questão de difícil abordagem". De acordo com a autora, as discussões sobre violência de gênero até as décadas de 1960/1970 se inseriam apenas nos estudos sobre atitudes e opiniões. Atualmente, são incluídas nos estudos sobre gênero as categorias relacionadas ao poder.

No debate em torno da violência, especificamente contra a mulher, a autora se afasta da concepção marxista ortodoxa que atrelava a violência às questões da estrutura capitalista e traz a reflexão atrelada à cultura a qual pertencemos. Sobre isso, afirma: "Como consequência, homens seriam violentos nessa cultura, marcada pela lógica patriarcal e androcêntrica; mulheres seriam vítimas por essa mesma lógica" (SMIGAY, 2002, p. 36).

O sexismo está culturalmente presente em nossa sociedade. Se ele fosse "ensinado", direta ou indiretamente, apenas no lar e a escola fosse um espaço de desconstrução dessa cultura baseada no patriarcalismo, na qual o homem ocupa uma posição superior à mulher, acreditamos que 
existiria uma redução das cenas de violência contra a mulher exibidas atualmente na mídia em geral.

Para ilustrar nossa reflexão sobre o tema, apresentamos a charge de Armandinho (Figura 1), na qual podemos verificar que, embora sendo ainda uma criança, o menino já tem uma prática sexista com outra criança, que é uma menina, colocando-a em posição de inferioridade. As relações de gênero refletem aquilo que as pessoas interiorizaram através do que aprenderam em casa, na escola, na igreja, na sociedade em geral. Estas, quase sempre, ensinam às crianças do sexo masculino a se diferenciarem bastante das crianças do sexo feminino, do mesmo modo, a respeito daquilo que cada um é, vale e pode fazer. Isso está refletido no comportamento machista do menino na tirinha da Figura 1.
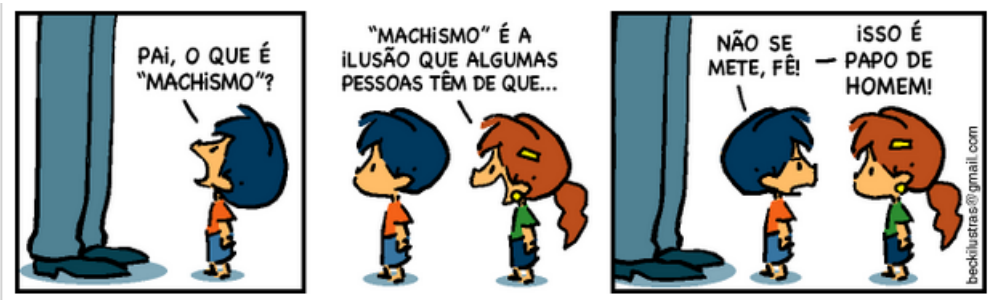

Figura 1 - O que é machismo?

Fonte: Google. Disponível em: http:/ /3.bp.blogspot.com/ C7KVEOa0JNo/VMztQ4wm1jI/AAAAAAABeA/fekkJ3KIPUk/s1600/1\%2Ba\%2B1\%2Ba\%2Ba\%2Ba\%2Ba\%2Bsexi\%2Bprinc.png

A mulher, desde a infância, é colocada "em seu lugar", ou seja, em um espaço privado. É negado a ela o direito de se expressar, de opinar, ela não deve participar de 
conversas tidas como masculinas. Sobre questões relacionadas à fala das meninas, Lakoff traz a seguinte reflexão:

Se uma menininha 'fala grosso' ou de modo rude como um menino, ela vai normalmente ser isolada, xingada ou ser motivo de gozação. Dessa forma, a sociedade, por intermédio do pai, da mãe e dos amigos de uma criança, a mantém 'na linha', em seu lugar [...]. Se a menininha aprende bem sua lição, ela não é recompensada com uma aceitação irrestrita pela sociedade; ao contrário, a aquisição desse estilo particular de fala será mais tarde uma desculpa que os outros usarão para mantê-la em uma posição inferior, para recusarem-se a levá-la a sério como ser humano. (LAKOFF, 2010, p. 15)

Na sociedade há uma exigência de um alinhamento entre gênero e sexo, suscitando nos sujeitos a necessidade de se auto afirmarem, buscando relações, ao longo da vida, que os constituam como sujeitos, numa confluência de determinantes sociais e biológicos. Essa busca é determinada pelas relações de gênero que preconizam de que maneira devem constituir-se cada sujeito, numa perspectiva machista em que homens são detentores do poder, da força e virilidade.

O machismo é uma das ideologias fundantes de diversas sociedades, relegando privilégios e poder ao homem/ macho que se sobressai, colocando a fêmea/mulher em 
um lugar de inferioridade e subalternidade. Por esse motivo, as relações entre gêneros são também compreendidas como relações de poder. Na opinião de Costa (2008, p. 22), "quando falamos em relações de gênero, estamos falando de poder. Na medida em que as relações existentes entre masculino e feminino são relações desiguais, assimétricas, mantém a mulher subjugada ao homem e ao domínio patriarca".

As relações de gênero são permeadas pela ideologia patriarcal e exercem grande influência na constituição dos sujeitos discursivos, determinam normas de conduta e estabelecem diretrizes na inter-relação entre os sujeitos. Tais relações demarcam as vozes ideológicas que cercam determinada coletividade social. Scott (1995) aponta a concepção de gênero como uma construção social articulada à noção de poder. Segundo o autor, gênero é um elemento constitutivo das relações sociais baseadas nas diferenças percebidas entre os sexos e uma forma de significar as relações de poder.

Louro (2003) também corrobora com essa discussão, afirmando que

É necessário demonstrar que não são propriamente as características sexuais, mas é a forma como essas características são representadas ou valorizadas, aquilo que se diz ou se pensa sobre elas que vai constituir, efetivamente, o que é feminino ou masculino em uma dada sociedade e em um dado momento histórico. Para que se compreenda o lugar e as relações de homens e mulheres 
numa sociedade importa observar não exatamente seus sexos, mas sim tudo o que socialmente se construiu sobre os sexos. O debate vai se constituir, então, através de uma nova linguagem, na qual gênero será um conceito fundamental (LOURO, 2003, p.21).

As relações de gênero moldam os sujeitos sociais que compõem o cenário da diversidade sexual e são categorias de análise que devem ser levadas aos diversos espaços públicos a fim de fomentar discussões e debates a respeito. A Escola é o lugar de estabelecimento de uma retórica que seja pensada a partir da própria diversidade, repleta de nuances e classificações que devem acompanhar fatos, cotidianos, aspectos socioculturais e a vivência de alunos e alunas das redes públicas e privadas.

Como afirma Saffioti (2004, p. 136), o gênero não é um conceito neutro. Pelo contrário, "carrega uma dose apreciável de ideologia" direcionando, assim, as formas de interação social. A célebre frase "Não se nasce mulher, torna-se mulher", de Beauvoir (1980), elucida a ideia do gênero como uma identidade construída a partir das relações entre sujeitos, localizados em um tempo e espaço bem definidos.

No interior dessas relações são evidentes, em um contexto essencialmente patriarcal, papéis preestabelecidos destinados ao homem e à mulher. Ao desempenhar estes papéis, a mulher aprende a ser mulher, bem como o homem aprende a ser homem. São figuras estereotipadas determinadas por fatores sociais, ideológicos e discursivos: homem não chora, fala grosso, impõe sua masculinidade 
através da força; a mulher, por sua vez, deve ser delicada, sensível e apta às atividades domésticas.

Todas essas questões observadas na sociedade se refletem na sala de aula. No próximo tópico, discutiremos como esse sexismo é construído na educação infantil.

\section{O sexismo na educação infantil}

O sentimento de infância surgiu na Modernidade. As sociedades antigas e medievais enxergavam as crianças como adultos em miniatura. Esse novo entendimento a respeito da criança repercutiu profundamente na Pedagogia. (DANELON, 2015). Consequentemente, a educação passou a se ocupar da construção da subjetividade da criança moderna. Sobre isso, Resende (2015) afirma que:

A partir do momento em que a infância é inventada pela Modernidade fazendo-a ocupar esse espaço como sujeito-objeto, a educação passa a ser um imperativo, o que leva, também, à invenção da pedagogia moderna, como um campo científico e como política de conhecimento, constituindo-se de discursos voltados para o estudo e a acumulação de saberes sobre a criança e seu corpo, seu desenvolvimento, suas capacidades, suas vontades, suas tendências, suas brincadeiras, suas potencialidades, suas fragilidades, suas vulnerabilidades, seus instintos, suas paixões e potências que, por sua vez, se acoplam a práticas discursivas e não discursivas em que tais sabres se imbricam em mecanismos de poder, cujo resultado será a produção de uma criança específica, a produção da subjetividade infantil moderna (RESENDE, 2015, p. 129-130). 
Com o surgimento da Modernidade, outro olhar foi dado à criança, com isso a Pedagogia teve de ser reinventada para se adequar as necessidades dessa nova sociedade.

Aires (1981, p. 29) corrobora o surgimento desse sentimento de infância e complementa essa reflexão ao falar sobre as idades e suas funções sociais. "Primeiro, a idade dos brinquedos: as crianças brincam com um cavalo de pau, uma boneca, um pequeno moinho ou pássaros amarrados". O autor também reflete sobre a criança e a instituição educacional "depois, a idade da escola: os meninos aprendem a ler ou seguram um livro e um estojo; as meninas aprendem a fiar" (AIRES 1981, p. 29). A escola conduzia "destino" para as crianças de acordo com o sexo.

A Pedagogia passou a estudar o comportamento infantil, entender suas necessidades e capacidades para, através desse conhecimento, saber como melhor governar as crianças.

Segundo as Diretrizes Curriculares Nacionais para Educação Infantil, criança é:

Sujeito histórico e de direitos que, nas interações, relações e práticas cotidianas que vivencia, constrói sua identidade pessoal e coletiva, brinca, imagina, fantasia, deseja, aprende, observa, experimenta, narra, questiona e constrói sentido sobre a natureza e a sociedade, produzindo cultura (DCNEI, 2010, p. 12). 
O conceito que as Diretrizes trazem sobre criança faz com que reflitamos, principalmente, sobre: a) construção da identidade pessoal e coletiva e, b) a construção do sentido sobre a natureza e a sociedade, produzindo cultura. Ou seja, é ingênuo acreditar que a criança não constrói aquilo que vivencia.

As crianças observam em casa as relações entre os pais. Se esse pai grita com a mãe, bate na mãe, o menino aprende que tem poder sobre a mulher e menina aprende que tem que ser submissa aos homens. Ou seja, se essas ou outras violências simbólicas são construídas dentro de casa, as crianças estão propensas a reproduzir essa cultura quando adultos.

A escola, então, seria o espaço para desconstruir essa cultura vigente. Entretanto, quando chegamos às salas de aula da educação infantil, encontramos brinquedos destinados a meninos e a meninas. Para as meninas, os brinquedos referentes ao lar, como se o destino da mulher fosse ser mãe e dona de casa. Para os meninos, aviões, carros, caixa de ferramentas, ou seja, no futuro o menino poderá ser o que quiser.

Finco (2003), ao observar as brincadeiras entre meninos e meninas em uma escola de crianças de 0 a 6 anos, verificou que o sexismo existente no mundo adulto vai se construindo dentro da escola ao longo dos anos, pois nessa primeira fase as crianças ainda brincam com os brinquedos livremente, sem se preocupar se é de menino ou de menina. A autora afirma que "esses meninos e meninas ainda não possuem o sexismo da forma como ele está disseminado na cultura construída pelo adulto: as crianças vão aprendendo a oposição e a hierarquia dos sexos 
ao longo do tempo que permanecem na escola" (FINCO 2003, p. 95).

Ainda de acordo com a autora, as escolas possuem mecanismos, mesmo que sutis, que constroem as diferenças de gênero entre meninos e meninas, e essa construção pode resultar na formação de homens e mulheres que buscam atender as relações que a sociedade estabelece, ou seja, os primeiros como fortes e capazes de tudo e as mulheres submissas, onde acreditam que é seu dever assumir todas as responsabilidades do lar, mesmo trabalhando fora de casa também. "Muitas pesquisas apontam que a escola possui mecanismos sutis que constroem e mantêm as diferenças entre os sexos" (FINCO, 2003, p. 93).

Esses são pequenos exemplos que deixam no subconsciente dos sujeitos envolvidos as marcas de uma cultura construída em cima do sexismo e da violência doméstica. Defendemos que a formação docente pode contribuir para a desconstrução dessa cultura sexista.

\section{Formação de professores: uma retrospectiva histórica até a atualidade}

Para se ter uma melhor compreensão em torno da formação de professores em nosso país, se faz necessário fazer uma retrospectiva pela história da educação brasileira. É justamente isso que Oliveira (2013) apresenta. Em um primeiro momento, logo após o "descobrimento" do Brasil, foram os Jesuítas os principais, para não dizer os únicos, que tomaram para si a responsabilidade com a educação da nova colônia portuguesa.

No ano de 1549, mesmo existindo uma grande preocupação com a catequese indígena, o processo de educação 
formal aqui existente era voltado para a elite. Sendo assim, a formação de professores era organizada a partir dessa perspectiva. Esse era o único sistema educacional brasileiro e perdurou até o ano de 1759, quando os jesuítas foram expulsos da nossa terra pelo Marquês de Pombal (OLIVEIRA, 2013).

A nova administração mudou a forma como o ensino era organizado. Começou um sistema intitulado "aulas régias". Era um ensino destinado a nobreza. Porém, diferente do ensino jesuíta, esse era fragmentado e sem objetivos claros. Essa forma de ensino perdurou mesmo após a Proclamação da Independência do Brasil. Em 1834, a responsabilidade do ensino e da formação de professores ficaram a cargo do governo das províncias. O ensino continuou sendo ministrado por professores "leigos", sem formação específica para ministrar os conteúdos das diversas disciplinas.

Em 1835, começam a surgir as Escolas Normais, que tinham por objetivo formar professores para o ensino primário. Nessas escolas faltavam verbas e professores preparados, didaticamente, para cumprir a função de formar novos professores para o ensino primário de nosso país. Mas, é inegável o avanço que se teve com a criação dessas escolas.

Na retrospectiva feita por Oliveira (2013), recebe destaque a criação do Pedagogium, primeiro Centro de Estudos Pedagógicos em nível Superior, em 1890. Esse Centro teve uma duração rápida e não conseguiu se consolidar. Nesse momento, o poder público não se responsabilizou pela educação superior e quem assumiu esse papel foi assumido por instituições religiosas de iniciativa privada que estavam organizadas aqui no Brasil. 
Em 1901, foi criado o primeiro instituto de educação em nível superior. Vários avanços podem ser vistos nessa época, pois o poder público passou a se preocupar e investir na formação de professores. Na década de 1970, os cursos de pós- graduação começaram a impulsionar as pesquisas em torno da educação. Até então, a formação de professores tinha um caráter tecnicista.

Em 1996, pode-se observar na LDB que a formação de professores tem que atender a três aspectos essenciais, dentre eles, a associação da teoria com a prática. Nesse ponto, Ferreira (2014) debate a complexa relação entre teoria e prática pedagógica. Sobre teoria, podemos entender como um "conjunto de regras ou leis, mais ou menos sistematizadas, aplicadas a uma área específica" (HOUAISS, 2014). No que diz respeito à prática, podemos entender como "ação, ato ou efeito de fazer (algo)". O século passado ainda manteve a tendência do século XIX, influenciado pelo método cartesiano, que via uma maior eficácia na divisão do conhecimento em campos especializados.

Esse pensamento afeta diretamente todas as áreas do conhecimento, inclusive a educação. Instala-se uma cisão entre teoria e prática, criando uma dicotomia entre professor e pesquisador. Substituir a teoria cartesiana por uma teoria da complexidade (teoria holística) é uma necessidade a ser alcançada no século XXI.

Ferreira (2014) aponta a práxis como método para romper com a cisão entre teoria e prática. Sobre práxis, entendemos "a atitude (teórico-prática) humana de transformação da natureza e da sociedade" (FERREIRA 2014, p. 35, apud PIMENTA, 2009, p.86) 
A formação docente para educação infantil:

desafios e particularidades

A retrospectiva histórica da formação docente mostra um pouco dos avanços e retrocessos que tivemos em torno dessa temática. Nesse tópico, abordaremos a formação docente, especificamente para educação infantil.

Em um primeiro momento, situaremos o local de atuação e os sujeitos envolvidos diretamente com esse profissional. De acordo com as Diretrizes Curriculares Nacionais para Educação Infantil, as creches e/ ou pré-escolas foram atendidas como direito social das crianças através da Constituição de 1988, que fala do dever do Estado para com a Educação. Sendo assim, começou a existir uma mudança de concepção em torno dos locais onde as crianças eram deixadas quando as mães iam trabalhar. Sobre essa mudança, as Diretrizes apresentam o seguinte:

Desde então, o campo da educação infantil vive um intenso processo de revisão de concepção sobre educação de crianças em espaços coletivos, e de seleção e fortalecimento de práticas pedagógicas mediadoras de aprendizagens e do desenvolvimento das crianças (DCNEI, 2010, p. 7).

Houve uma mudança de concepção em torno dos locais destinados a crianças de 0 a 5 anos. Também é exigida uma mudança no profissional que atua nessas instituições. A LDB 9.394/96, em seu artigo 62, fala da necessidade de termos um profissional formado em nível superior para 
atuar na educação básica, ou no mínimo, que tenha uma formação de nível médio, na modalidade normal.

Rocha (2012) faz uma reflexão sobre a relação das crianças com a educação que elas recebem. Na visão da autora, o aluno inicia a fase estudantil na primeira infância aprendendo conteúdos práticos que facilitarão, posteriormente, seu período de alfabetização e toda a vida acadêmica, e que serão essenciais para sua vida adulta.

A formação do docente para atuar com criança, mais do que em qualquer outra faixa etária, precisa estar direcionada com questões ligadas à formação de um sujeito que se desenvolva livre de preconceitos (seja de gênero, de classes sociais, de etnias), pois, é nessa fase que as crianças vão construindo internamente os valores sociais que irão levar para a vida adulta.

Finco (2003) destaca o papel do educador da educação infantil como fundamental na desconstrução da cultura sexista existente no mundo adulto. E para que esse papel seja cumprido de forma exitosa, faz-se necessário uma formação que abarque todas as questões relacionadas ao gênero e sua construção dentro das escolas. Sobre isso, a autora afirma que: "deste modo, o profissional de educação infantil tem papel fundamental para que essas relações possam acontecer de forma livre, sem cobranças quanto a um papel sexual pré-determinado" (FINCO, 2003, p. 95).

Sobre a formação permanente dos docentes que trabalham na Educação Infantil, Rocha (2012, p. 31) comenta que "somente aprofundando-se nos estudos para a compreensão do desenvolvimento humano, o professor poderá desenvolver seu trabalho com a qualidade que a Educação Infantil necessita". 


\section{Formação de professores $\mathrm{x}$ sexismo}

Uma formação docente adequada para combater o sexismo se faz necessário. Estamos inseridos em uma cultura baseada no preconceito, principalmente relacionado às mulheres, ou ao que se considera feminino. É necessário que tenhamos a compreensão de que as nossas ações em sala de aula legitimam ou não essa cultura. Devemos educar as crianças para abolirem o ciclo do machismo, agindo com atitudes que destruam sua perpetuação.

Finco (2003) alerta sobre o papel do educador na reafirmação ou desconstrução dessa sociedade sexista. Se esse profissional não reflete sobre suas atitudes em sala de aula, ele pode estar contribuindo para a cristalização de concepções sexistas na cabeça das crianças. Nas palavras da pesquisadora,

quando a professora não reflete sobre sua influência nas relações dos meninos e meninas, ela pode organizar a brincadeira de uma forma a favorecer o sexismo, a prática da professora pode fazer com que as crianças se organizem em grupos distintos de meninas e meninos, sem que haja uma ordem explícita para isso (FINCO, 2003, p. 98).

É importante entendermos que fomos educados sob uma cultura sexista, onde as brincadeiras de meninos e meninas eram separadas. Perdi as contas de quantas vezes sai escondida para jogar bola com meu irmão e com pouco tempo ouvia a voz da minha mãe "entra menina, vá 
brincar de boneca com sua irmã, ta vendo que não dá certo você brincar lá fora misturada com os meninos" (Arilane). Isso sempre criou em mim a visão de que o homem era livre e às mulheres cabia o espaço privado do lar.

Essa situação acontece até hoje e dentro das escolas também. Muitas vezes as professoras mandam os meninos para o pátio para jogar bola e deixa as meninas na sala brincando de casinha. Sendo assim, como disse Finco (2003), se nós educadores não fizermos um trabalho de reflexão em torno das nossas próprias atitudes iremos está contribuindo direta ou indiretamente com a reafirmação da sociedade sexista, pois atitudes como essas, citadas acima, contribuem para uma compreensão de que o lugar da mulher é sempre privado, seja dentro de casa, de uma sala; já os meninos são livres para irem aonde quiser.

Sobre o enraizamento da cultura sexista, Louro (2000) afirma que

Em nossa sociedade, a norma que se estabelece, historicamente, remete ao homem branco, heterossexual, de classe média urbana e cristão e essa passa a ser a referência que não precisa mais ser nomeada. Serão os 'outros' sujeitos sociais que se tornarão 'marcados', que se definirão e serão denominados a partir dessa referência. Desta forma, a mulher é representada como 'o segundo sexo' e gays e lésbicas são descritos como desviantes da norma heterossexual (LOURO, 2000, p. 9). 
Como foi dito anteriormente, os professores, estão imersos em uma cultura preconceituosa. Não é a toa que a escola, historicamente, tem cumprido o papel de reafirmar as desigualdades. Acerca dessa construção da escola, Louro (2000, p. 11) pondera que "o investimento mais profundo, contudo, o investimento de base da escolarização se dirigia para o que era substantivo: para a formação de homens e mulheres "de verdade".

Devemos começar um processo de desconstrução dessa concepção de sociedade patriarcal, falocrática e sexista que está posta. Para Finco (2003, p. 99), “a proposta da desconstrução das dicotomias significa problematizar a constituição de cada pólo, demonstrar que cada um, na verdade, supõe e contém o outro; mostrar que cada pólo não é único, mas plural".

A autora defende a necessidade de uma desconstrução dessa cultura de gêneros em que estamos submersos e que é refletida na escola. Principalmente, no que diz respeito a como as crianças entendem as relações de gênero que são postas no seu dia a dia. Tais relações foram construídas historicamente em pólos distintos. "A desconstrução dos pólos masculinos e femininos traz uma proposta de reflexão e nos aproxima das formas como as crianças se relacionam frente às diferenças de gênero na infância" (FINCO, 2003, p. 99).

Louro (2003) sustenta a ideia de que gênero é uma construção social, que está intrinsecamente relacionado aquilo que a sociedade considera como o papel social/ cultural mais adequado para homens e mulheres e está relacionado às noções construídas de masculinidade e feminilidade. 
Uma formação docente baseada em uma concepção mais holística, que enxerga o ser humano em todos os seus aspectos, na sua complexidade, faz com que comecemos a desconstruir o ciclo do sexismo dentro das salas de aula da educação infantil. Para que isso se concretize, é necessário fazer uma reflexão sobre o currículo escolar e o sexismo.

No que diz respeito ao ensino nos cursos de formação de professores, Altman (2013) comenta sobre alguns motivos que levam as universidades a não terem nos currículos de licenciaturas disciplinas ligadas às questões de gênero, sexualidade e diversidade sexual. Segundo a autora, os cursos de graduação quase não contemplam esses temas, devido a vários aspectos.

Sem ter a pretensão de abordá-los na sua plenitude, gostaria de me referir a alguns deles. Diferentemente do ensino escolar, as universidades são dotadas de maior autonomia, inclusive no que se refere ao conhecimento. A autonomia universitária propicia tanto a inclusão quanto a ausência desses temas nos seus currículos (ALTMAN, 2013, p. 79).

Um dos aspectos apontados é a autonomia que as Universidades possuem para elaborarem seus currículos. Sendo assim, dependendo da linha de pesquisa em que os professores dos cursos de licenciatura estejam inseridos, as graduações não ofertam disciplinas que debatam a questão de gênero com os futuros educadores da escola 
básica. São esses educadores que ao chegarem às escolas contribuirão com o debate em torno do Projeto Político Pedagógico, são esses professores que escolherão o livro didático a ser trabalhado na escola. Enfim, se esses profissionais não tiverem uma formação adequada em torno da questão de gênero, a tendência é negligenciar essa discussão na educação básica e reforçar cada vez mais o sexismo entre as crianças.

Ribeiro e Silva comentam que o currículo escolar

parece ignorar os/as alunos/as como sujeitos sociais e históricos, constituídos/as dentro de determinada cultura, preocupando-se apenas em instituir padrões, normas, habilidades, valores e outros condicionantes; o currículo escolar acredita que de fato esteja efetivando a formação de bons cidadãos (RIBEIRO e SILVA, 2011, p. 525).

Não ter um currículo que problematize as questões de gênero fará com que acreditemos que estamos construindo bons cidadãos para a sociedade sem se preocupar em que tipo de cidadão, de fato, queremos para a sociedade. Será que a boa cidadã é que aquela que senta de perna cruzada, que fala baixo, que não reage? Será que o bom cidadão é aquele que entende ser livre para fazer o que quiser, ou seja, explorar mãe e mulher dentro de casa sem contribuir com as atividades domésticas? Enfim, temos que ter cuidado em não estarmos apenas reproduzindo os "bons cidadãos" que já temos. 
Como já foi dito, a falta de um currículo que contemple as discussões de gênero dentro das universidades reflete na ausência dessa discussão dentro da escola.

Outra questão importante apontada por Altman (2013) diz respeito ao atendimento da demanda social e histórica que as escolas procuram contemplar em seus currículos no que diz respeito à educação sexual. Sobre isso, a autora afirma que "as intervenções sobre a sexualidade na escola passaram por diferentes focos de atenção, como o onanismo, as DSTs, a Aids, a chamada gravidez na adolescência e agora o respeito à diversidade sexual" (ALTMAN, 2013, p. 73).

A autora aponta o percurso das discussões em torno da sexualidade dentro da escola e só que recentemente se começou a discutir sexualidade no âmbito da diversidade sexual, com a inclusão de debates em torno do respeito, entre outras questões ligadas a heterogeneidade.

Amado (2010) traz uma reflexão importante acerca da mudança de concepções em torno do currículo nos cursos de formação de professores,

[...] nos tempos atuais, o currículo deve buscar entendimentos e práticas em pequenos marcadores sociais, suas chamadas minorias, diferenças, que abrem a agenda educacional para questões de gênero, escolhas sexuais, multiculturalismo, religiosidade, força da mídia e dos artefatos culturais, políticas de identidade, racismo, etnocentrismo e etc (AMADO, 2010, p. 5). 
Como já foi dito por Altman (2013) as questões curriculares que discutem a sexualidade como um todo vão tentar contemplar as demandas históricas de cada época. Podemos observar na mídia e em outros espaços que a sociedade vem mudando, casamento homossexual sendo permitido por lei, o empoderamento feminino através de diversos movimentos, como por exemplo "A Marcha das Vadias", ou seja, a escola precisa trazer esse debate para dentro das salas de aula. Modificar o currículo para que esse debate seja contemplado é umas das principais pautas da atualidade. Pois, só educando esses novos sujeitos para uma sociedade aberta a diversidade é que vamos começar a desconstruir à violência que está posta para as minorias.

\section{Comentários finais}

A história da desigualdade, principalmente a de gênero, é datada de muitos séculos, desde o surgimento da propriedade privada nas sociedades primitivas. A partir daí, foi sendo construída uma cultura baseada no sexismo e em violências de todo tipo contra a mulher. Percebemos também que a escola vem cumprindo um papel de reafirmar essa cultura.

Para que a escola comece a desconstruir esse processo, algumas questões precisam ser observadas. Em primeiro lugar, no que diz respeito à formação docente. De nada adianta quebrar o ciclo do machismo dentro da escola se não temos professores capacitados para isso. Sendo assim, os cursos de Licenciatura devem ampliar as disciplinas relacionadas às questões de gênero. Em um segundo momento, os professores da educação infantil precisam 
entender que suas atitudes em sala de aula contribuem, direta ou indiretamente, com a formação do sujeito. E por fim, é preciso, de forma transversal, trabalhar a sexualidade dentro da escola, iniciando na educação infantil.

A escola não apenas transmite conhecimento, ela também fabrica sujeitos, produz identidades étnicas, de gênero, de classe. Reconhecemos que essas identidades estão sendo produzidas através de relações de desigualdade. Romper com os modelos hegemônicos não é uma tarefa fácil. A prática predominante na educação infantil ainda possui a forte influência da formação para o ensino tradicional, onde há o predomínio do binômio masculino/feminino. Não podemos deixar que esse predomínio ofusque outros caminhos. Aspiramos uma educação em que os meninos e meninas não sejam ensinados a gostarem de coisas diferentes, a fazerem coisas diferentes, a serem hábeis em funções ou tarefas distintas.

Orientar a educação sexual infantil requer uma consolidação de competências didáticas, debates constantes, desmistificação de discriminações, preconceitos, estereótipos e "padrões sexuais", construir a disseminação do respeito entre os alunos e professores assim como entre alunos e alunas.

Devemos olhar a educação infantil para além das diferenças, pois é nesse espaço que se inicia a luta para uma educação não sexista e nessa batalha os professores desempenham um papel relevante, é a partir de suas práticas que estereótipos podem ser quebrados. A escola é um ambiente de extrema importância para o desenvolvimento de meninas e meninos, e neste espaço as crianças devem se relacionar livremente, independente de gênero. 
Defendemos que é possível uma educação igualitária para meninas e meninos.

Acreditamos que só uma formação docente baseada na construção de uma sociedade mais justa e livre de preconceito poderá educar crianças capazes de desconstruir a cultura vigente, formando adultos que não tenham discriminação de gênero, classes sociais, etnias etc.

\section{Referências}

ALTMAN, Helena. Diversidade sexual e educação: desafios para a formação docente. Revista Latino Americana Sexualidad, Salud y Sociedad. Campina-SP, 2013, p. 69-82.

AMADO, Paula Barreto Doria. Relações de "Poder e Saber" no currículo: enquanto formação, controle e disciplina do corpo na escola. GT8. Espaços Educativos, Currículo e Formação Docente. Tiradentes/SE. 2010, p. $1-10$.

BEAUVOIR, Simone. O Segundo sexo - a experiência vivida. Tradução de Sérgio Millet. 4. ed. São Paulo: Difusão Européia do Livro, 1980.

BRASIL. Ministério da Educação. Secretaria de Educação Básica. Diretrizes curriculares nacionais para a educação infantil /Secretaria de Educação Básica. Brasília: MEC, SEB, 2010.

COSTA, Ana Alice. Gênero, poder e empoderamento das mulheres. 2008. Disponível em: http://www. 
adolescencia.org.br/empower/website/2008/imagens/textos_ pdf/Empoderamento.pdf. Acesso em: 26/11/2013.

Dicionário Houaiss On-line Beta da Língua Portuguesa. Disponível em: http://houaiss.uol.com.br. Acesso em: 30/05/2016

ENGELS, Friedrich. A origem da família, da propriedade privada e do Estado. 15. ed. Rio de Janeiro: Bertrand Brasil, 2000

FERREIRA, Jacques de Lima. A complexa relação entre teoria e prática pedagógica na formação de professores. Petrópolis, RJ: Vozes, 2014.

FINCO, Daniela. Relações de gênero nas brincadeiras de meninos e meninas na educação infantil. Revista Proposições. v.14. n 3. set/ dez. p. 89-101. São Paulo, 2003.

LAKOFF, Robin. Linguagem e lugar da mulher. In:

FONTANA, Beatriz; OSTERMANN, Ana Cristina (Orgs.). Linguagem, gênero e sexualidade. São Paulo: Párabola, 2010, p.15.

LOURO, Guacira Lopes Gênero, sexualidade e educação: uma perspectiva pós-estruturalista. 6. ed. Petrópolis, RJ: Vozes, 2003.

LOURO, Guacira Lopes (Org.). O corpo educado: pedagogias da sexualidade. Belo Horizonte: Autêntica, 2000. 
OLIVEIRA, Maria Marly de. Formação de Professores: produção de conhecimento - sequência didática. Petrópolis, RJ: Vozes, 2013.

PIMENTA, S. G. O estágio na formação de professores: unidade teoria e prática. 8. ed. São Paulo: Cortez, 2009.

RIBEIRO, Paula Regina Costa. SILVA, Benícia O. da. Sexualidade na sala de aula: tecendo aprendizagens a partir de um artefato pedagógico. Estudos Feministas. Florianópolis, 2011, p. 521-533.

ROCHA, Luciana Caprice Silva Santos da. Formação de professores na educação infantil. Revista Projeção e Docência. v.3. n.1. 2012, p.35.

SAFFIOTI, Heleieth I. B. Gênero, patriarcado, violência. São Paulo: Fundação Perseu Abramo, 2004.

SCOTT, Joan W. Gênero: uma categoria útil de análise histórica. Educação \& Realidade. Porto Alegre. v. 2, n. 20, p. 71-99, jul/dez., 1995.

SMIGAY, Karin Ellen Von. Sexismo, homofobia e outras expressões correlatas de violência: desafios para a psicologia política. Psicologia em Revista. v. 8. n. 11. Belo Horizonte, 2002, p. 32-46.

VERÍSSIMO, Luis Fernando. Sexa. In: Comédias para se ler na escola. Rio de Janeiro: Objetiva, 2001, p. 53-54. 


\title{
O LUGAR DA ESCRITA NO COTIDIANO DO PROFESSOR DO ENSINO FUNDAMENTAL I: o que revelam os discursos
}

\author{
Tatiana Dias Ferreira ${ }^{1}$ \\ Maria de Lourdes da Silva Leandro ${ }^{2}$
}

\section{Introdução}

Em torno do processo da produção do texto escrito, algumas pesquisas no campo da Linguística Aplicada têm focalizado aspectos relativos ao domínio da unidade textual, discutindo conhecimentos de natureza linguística e normativa que definem o que seja escrever adequadamente um texto, inclusive, algumas com ênfase no processo do escrever, quanto à prática da reescritura do texto, trabalhando aspectos linguísticos, ortográficos, entre outros.

1 Professora Mestre em Formação de Professores pelo PPGFP/ UEPB. Docente Efetiva do Ensino Fundamental I no Município de Campina Grande - PB - Secretaria de Educação. Tem experiência na área de Educação, atuando principalmente nos seguintes temas: discurso (AD Francesa), produção de texto escrito na escola, aquisição da leitura e da escrita e metodologias (concepções) de alfabetização.

2 Professora Doutora em Linguística e Ensino pela UFPB/ PROLING. Docente Efetiva do Departamento de Letras e Artes e do Programa de Pós-Graduação em Formação de Professores da Universidade Estadual da Paraíba/Campus I. Professora pesquisadora na área da Análise de Discurso (francesa). 
Nesse contexto, essas pesquisas têm trazido discussões que questionam o modo como se tem desenvolvido o ensino do escrever, na escola. São pesquisas que focalizam ora a metodologia, ora o texto escrito, ora o aluno que precisa aprender a dominar as "regras" para desenvolver tal competência em textos de gênero, praticamente, escolares, que priorizam o tipo textual, como narração, descrição, dissertação, argumentação.

Apesar da abertura, na escola, para a produção de gêneros de função social, como a notícia, a carta, entre outros, a sua funcionalidade sempre é escolar. Essa configuração contextual evidencia a compreensão do escrever na escola, cuja prática escolar com o escrever textos, focalizando o conhecimento voltado para habilidades específicas de gêneros textuais escolares, percorre toda a escolaridade do sujeito em formação. Considerando-se a progressão do aluno na vida escolar, a elaboração dos textos a serem experienciados vão evoluindo em termos de complexidade estrutural e linguística à medida que se progride na formação, mas é sempre uma prática regrada pelo discurso institucional escolar.

Refletindo sobre as questões delineadas acima, acerca da relação entre linguagem e a produção do texto escrito escolar e a formação do aluno, percebemos que na compreensão que se construiu, ao longo do tempo, entre texto e autor não se dá espaço ao sujeito que produz sentido(s) na/pela linguagem, o que nos parece ser um dado consideravelmente pertinente, conforme afirmam os estudos no domínio do discurso, entendido como processo de produção de sentido(s), situado(s) na história, na cultura, no social, na ideologia. Quem produz sentido(s) é o homem, subjetivando-se pela linguagem. 
Desse modo, fundamentados pela contribuição teórica da Análise de Discurso de linha francesa (AD), entendemos que seus conceitos teóricos e mecanismos analíticos, em torno do texto, do sujeito e da linguagem, na ordem do discurso, podem contribuir para uma reflexão sobre esse tema. Valorizar o modo como o sujeito se constitui, produzindo sentidos, situados sócio-historicamente, e sua discussão sobre como se movimenta o sujeito no discurso pela / na linguagem, nos textos, revelam outros caminhos para se pensar o lugar do professor, na sua relação com o texto que escreve, seja no contexto de seu cotidiano, seja no ensino da escrita em sala de aula.

Essa preocupação em torno do ensino da produção escrita na escola, evidenciando a importância do lugar do sujeito que escreve, aponta, por sua vez, uma questão que está na base dessa discussão: a inscrição do professor nesse processo, pois entendemos que não podemos ensinar a escrever se não escrevemos, considerando o sentido do "escrever", como uma prática de escrita de texto e não somente de frases ou de modelos de textos, estereotipados e circunscritos a um domínio escolar.

Sabemos que a aquisição e desenvolvimento da leitura e da escrita desenvolve-se através de situações diversificadas que configurem uma prática em que o sujeito deve ser ativo nesse processo. Também, por outro lado, sabemos que essa prática só se instaura em meio a condições adequadas, como a da interação com o(s) outro (s). Sendo assim, aprende-se a escrever, escrevendo, bem como ensina-se a escrever, aquele que faz do escrever uma prática cotidiana. Também é fato que escrever textos como uma prática, e gostar de escrever são requisitos não tão "naturais", pensando em nossa realidade social, inclusive, 
escolar. Esse domínio e uso depende das condições e dos objetivos do sujeito que precisa fazer uso da escrita.

No contexto dessas reflexões, destacamos esse tema a inscrição do professor na sua relação com a prática de escrita-, como objeto que inaugura novas discussões no contexto dos estudos sobre a formação do professor. Esse artigo apresenta-se como um resgate bastante reduzido do trabalho desenvolvido na Dissertação de Mestrado "Professora escrevendo em sala de aula: um outro modo de fazer uma 'formação continuada'", da professora-Mestre Tatiana Dias Ferreira (UEPB/MFP, 2016), trabalho, motivado por esse tema. Desse contexto, focalizamos, nesse artigo, dados da pesquisa que originou esse trabalho, voltados para a primeira etapa da experiência interventiva, realizada com uma professora do Ensino Fundamental I de uma escola municipal de Campina Grande/PB. Essa etapa procura situar a história da professora, quanto à sua vivência com a prática da escrita, no seu cotidiano.

Em função desse direcionamento, as reflexões nesse artigo procuram se articular em torno da seguinte questão-problema: De que modo a vivência com a prática de escrita da professora, no seu cotidiano, revela concepções que fundamentam a direção dada ao ensino da produção escrita na sala de aula? Entre outros objetivos, procuramos trazer contribuições acerca da importância de se redimensionar a relação do professor com a sua prática de escrita, considerando sua história, como uma das condições, historicamente situadas, para se discutir o ensino e a formação do professor.

Nosso referencial teórico fundamenta-se em Pêcheux (1975, 2009), Orlandi (2012a 2012b, 2013), Kleiman (2001), entre outros. Trabalhamos com a pesquisa de natureza 
qualitativa, cujos dados foram fornecidos pelo sujeito dessa pesquisa: a professora do $1^{\circ}$ Ciclo Final $\left(3^{\circ}\right.$ ano B) de uma escola municipal. Entendemos, então, que discutir o lugar do professor na sua história de escrita é condição primordial nas discussões sobre o ensino da produção escrita em sala de aula.

Esse artigo assim se organiza, trazendo inicialmente um recorte do arcabouço teórico que fundamentou essa pesquisa. Destacamos a contribuição da Análise de Discurso (AD), quanto às concepções de discurso, sujeito, linguagem e texto relacionados com as noções teóricas sobre a tradição escolar em torno do escrever texto e sobre a prática da escrita na formação docente. Desenvolvemos nosso artigo, apresentando nossa análise discursiva, evidenciando recortes de entrevista e questionário, feitos junto à professora do ensino fundamental, como parte I dessa analise. Nesses dizeres, configuram-se suas concepções sobre o ato de escrever e sobre como essas concepções são referências para o ensino da língua materna. Esses sentidos serão interpretados no recorte que apresentamos de aulas observadas na sala de aula da referida professora, como parte II e conclusiva de nossa leitura analítica.

Finalizamos este artigo, apresentando nossas considerações finais, seguidas das referências bibliográficas.

\section{Um recorte teórico}

Discurso, Linguagem, Sentido, Texto

A Análise de Discurso (doravante AD) considera a língua a partir do contexto social, histórico e ideológico em que um determinado enunciado foi produzido. Assim, 
trata do discurso, da linguagem e do(s) sentido(s) de uma maneira particular, isto é, concebe a língua fazendo sentido, sendo vista socialmente, constituída por natureza ideológica e pela sua história, e o discurso como processo de produção de sentidos, situados sócio - historicamente.

Nesse contexto, para Pêcheux (1975 apud BRANDÃO, 2004), o discurso significa um objeto em que se empregam as questões relacionadas à língua, à história e ao sujeito, por isso, a $\mathrm{AD}$ não trata da língua de forma abstrata, mas relaciona a linguagem com o contexto social no qual o sujeito está inserido, sabendo que há um sujeito com determinada identidade social e histórica. Entre língua, sujeito e discurso, Orlandi (2013) lembra que o discurso revela-se na prática viva da linguagem, constrói-se permanentemente, pois é um processo de construção de sentidos sempre em movimento, em curso, produzindo, como diz Pêcheux ([1975] 2009) efeitos de sentidos. Logo, necessita da língua e do sujeito para se materializar.

Fernandes (2008) comenta que o discurso não é a língua, nem a fala, ele está no social, logo, exterior à língua. É, portanto, um lugar fora do sujeito, fora da língua, no qual o sujeito se inscreve no social, histórica e ideologicamente, daí dizermos que o discurso encontra-se na exterioridade, no meio social, na medida em que expomos um ponto de vista, uma ideia ou uma opinião sobre um determinado tema em nosso cotidiano. Assim, reiteramos que o discurso não é a língua e nem a fala, mas necessita de ambas para existir concretamente, para se materializar. Referente a este pensamento o autor nos assevera que

Para falarmos em discurso, precisamos considerar os elementos que têm existência no social, as ideologias, 
a História. Com isso, podemos afirmar que os discursos não são fixos, estão sempre se movendo e sofrem transformações sociais e políticas de toda natureza que integram a vida humana (FERNANDES, 2008, p.14).

Como condição para o discurso existir é preciso levar em consideração a produção de sentidos dos sujeitos, que realiza a todo tempo um processo de significação. Isto é possível quando compreendemos a linguagem como sistema dinâmico, aberto a rupturas, ao equívoco.

Esse sistema que revela processos de identificação, de argumentação, da subjetivação, da construção da realidade, processo de assujeitamento, enfim, materializa a relação entre o discurso e língua, uma relação entre sujeitos e sentidos, que são muitos e diversos. Assim, quando falamos em discurso é necessário que nos reportemos para as questões do social e da ideologia, uma vez que estão impregnadas em nosso dizer ao enunciarmos algo.

Segundo Orlandi (2012b), os processos de produção do discurso implicam três momentos relevantes:

Sua constituição, a partir da memória do dizer, fazendo intervir o contexto histórico-ideológico mais amplo; sua formulação, em condições de produção e circunstâncias de enunciação específicas e sua circulação que se dá em certa conjuntura e segundo certas condições. (ORLANDI, 2012b, p. 9). 
Isto significa que todo discurso é uma construção social, não individual, e que só pode ser analisado considerando seu contexto social, ou seja, ao interpretar um discurso devemos estar atentos para as questões sociais, históricas e ideológicas que o sujeito trouxe para dentro do seu texto. Para a autora, a memória é fundamental para "fazer valer" as condições de produção, nesse sentido, a memória faz parte da produção do discurso. $\mathrm{Na} A D$, a memória é tratada como interdiscurso.

$\mathrm{O}$ interdiscurso se faz presente em toda formação discursiva através de discursos originários de diferentes sujeitos, diferentes lugares sociais, em diferentes épocas. Este conjunto de diferentes discursos que perpassam uma formação discursiva é denominado de interdiscurso. Conforme Orlandi,

Este é definido como aquilo que fala antes, em outro lugar, independentemente. Ou seja, é o que chamamos memória discursiva: o saber discursivo que torna possível todo dizer e que retorna sob a forma do pre-construído, o já-dito que está na base do dizível, sustentando cada tomada da palavra. O interdiscurso disponibiliza dizeres que afetam o modo como o sujeito significa em uma situação discursiva dada (2013, p. 31).

O interdiscurso é um conjunto de discursos já esquecidos que determinam o que dizemos, uma espécie de memória, considerada como memória discursiva, lugar onde se entrelaçam diferentes discursos, originados de 
lugares e situações sociais diversas, interligados e inscritos na memória. Desse modo, é o interdiscurso que vai definir o que pode ou não ser dito em certas condições de uma enunciação.

Segundo a autora, o dizer não é uma propriedade reservada do sujeito, tendo em vista que as palavras não são nossas, isto é, as palavras se significam através da história e da linguagem, pois o que foi dito em determinado lugar também possui significado em "nossas" palavras. Nesse sentido, "o sujeito diz, pensa que sabe o que diz, mas não tem acesso ou controle sobre o modo pelo qual os sentidos se constituem nele" (ORLANDI, 2013, p. 32).

Podemos considerar que o interdiscurso é a constituição dos sentidos e o intradiscurso a sua formulação (produção), assim, a fala de qualquer sujeito se encontra formada pela memória discursiva (interdiscurso) e pela atualidade (intradiscurso). É dessa relação que os sentidos se constroem, considerando que o sujeito passa a assumir outras posições, de acordo com o momento sócio - histórico e ideológico.

Não se fala de discurso sem considerar o sujeito, pois não há discurso sem sujeito, nem sujeito sem ideologia, assim, os discursos são governados por formações ideológicas que determinam o que pode ou não ser dito. Nesse contexto, a interação humana é, sem dúvida, um fator primordial para que aconteça a produção do discurso. Fernandes (2008, p. 40) afirma que "a interação envolve a natureza dos processos de produção do discurso, também chamado de prática discursiva".

$\mathrm{O}$ sujeito se desenvolve socialmente em meio a sistemas culturais, sociais, políticos, históricos, religiosos, entre outros, que determinam sua maneira de pensar, de 
agir e sua ação sobre o mundo. São desses diferentes lugares que os sujeitos produzem seus discursos. É o que a $\mathrm{AD}$ entende como formações discursivas (FD). Assim, em uma formação discursiva torna-se visível a presença da esfera social e ideológica, por isso, uma FD jamais será homogênea, mas será sempre impregnada de diferentes discursos, bem como, atravessada pelo discurso do outro.

Dessa forma, é na relação com o outro, com o dizer, que a linguagem se revela como um ato discursivo e social, haja vista que uma língua que se restringe apenas ao seu estudo interno, isto é, à sua estrutura, não é suficiente para se entender a produção dos sentidos. Considerar linguagem como ato discursivo, social, dinâmico requer a ampliação do entendimento sobre a noção de sujeito. De acordo com Fernandes (2008), para compreender o sujeito na perspectiva da $A D$, se faz necessário entender que o homem não é um ser isolado um do outro no mundo, mas necessita estar em constante interação, daí não se pode negar a nossa vivência em sociedade.

Desse modo, nessa perspectiva discursiva, o sujeito de discurso "não é um ser humano individualizado, e sim um sujeito que tem existência em um espaço social e ideológico, em um dado momento da história e não em outro" (FERNANDES, 2008, p. 24). Nesse sentido, é necessário compreender que o sujeito discursivo é um ser social, coletivo, que faz parte de um contexto histórico e ideológico, no qual sua voz expressa o lugar social, revelando um conjunto de outras vozes que não são suas, mas que integram e fazem parte da sua história, do seu lugar social.

O sujeito discursivo é descentrado, isto é, o sujeito na $\mathrm{AD}$ não está centrado nem no "eu" nem no "tu", mas na construção de sua identidade que resulta das posições do 
sujeito nos discursos, a partir da interação com o outro, em diversos lugares na sociedade, pois em cada discurso encontramos o outro inserido.

No âmbito dessa discussão, voltemos nossas reflexões para a noção de texto na $\mathrm{AD}$, e a importância do seu estudo, por se tratar do objeto mediante o qual o discurso se realiza. Entretanto, antes de refletimos acerca do texto na perspectiva discursiva, faz-se necessário que apresentemos duas concepções de texto presentes na Linguística.

Primeiro, a concepção de texto como produto, que, conforme Leandro (2011, p. 111), prioriza “a aquisição de modelos de texto, destacando-se o domínio da superfície formal". Considera o texto como uma unidade com início, meio e fim, priorizando a dimensão formal, coesa. Nessa concepção, a língua é compreendida como um sistema homogêneo e o texto como uma unidade pronta e acabada. Segundo, a concepção de texto como processo, que requer a interferência da esfera social e cognitiva. Essa concepção entende

O escrever texto como um trabalho que exige do escritor o desenvolvimento de etapas para se escrever, o texto é visto com processo. Essa abordagem procura explicar o que acontece durante o processo de produção. (LEANDRO, 2011, p. 111).

Nessa concepção, o texto é compreendido enquanto trabalho que é construído a partir da interferência da esfera psicocognitiva e social, de cada sujeito. Recusa-se a ideia de que, para produzir um texto escrito, basta 
somente dominar o sistema de escrita alfabética, considerando a língua apenas como um sistema de signos, pois é necessário compreender a linguagem como um sistema dinâmico, indispensável para o sujeito em suas práticas sociais.

É na perspectiva da linguagem enquanto sistema dinâmico, que o texto no contexto da $\mathrm{AD}$ "é definido pragmaticamente como a unidade complexa de significação, consideradas as condições de sua produção. O texto se constitui, portanto, no processo de interação" (ORLANDI, 2012a, p. 28). Para a autora, o texto não apresenta uma unidade completa em si mesma, pois seu sentido se constrói no espaço discursivo dos interlocutores, uma vez que podemos encontrar em um mesmo texto, enunciados de discursos distintos, que resultam de variadas formações discursivas, as quais podem ser de "diferentes naturezas: de confronto, de sustentação mútua, de exclusão, de neutralidade aparente, de gradação etc." (ORLANDI, 2012a, p. 76).

Considerando essa configuração teórica que delineia o modo como podemos compreender e articular o lugar do sujeito que produz sentidos, porque se movimenta na língua legitimadora da interação verbal e social, trazemos nessa discussão uma contribuição teórica sobre o que se diz em torno da escrita na formação do professor, uma vez que, nos dados que destacamos em análise, o sujeito de nossa pesquisa situa seu dizer levando sempre em consideração o seu lugar discursivo como professora, resultado de uma formação acadêmica. 


\section{A prática da escrita na formação do professor}

Conforme Bezerra (2007), nas últimas duas décadas do século XX, começaram a circular nas escolas brasileiras de ensino fundamental e médio, novos conceitos de escrita e de seu ensino, opondo-se assim, à concepção tradicional de escrita como produto. Essa "nova" concepção de escrita, segundo a autora, permeava a maioria dos livros didáticos de língua portuguesa nessa época, bem como o ensino de texto, relacionando-o à gramática e à tipologia clássica (narração, descrição e dissertação).

Assim, no início do século XXI, a proposta de ensino da escrita passa a ser concebida como uma prática social, fundamentada em situações concretas de comunicação. Para Bezerra (2007),

Ensinar a escrever pressupõe a aprendizagem de gêneros e suas relações com discursos e textos em circulação; a valorização da interação mediada pela escrita e de suas condições de produção; a abrangência de situações de produção de texto; e a aprendizagem dos usos linguísticos inerentes à elaboração e ao uso dos gêneros (BEZERRA, 2007, p. 148).

Comungamos com a autora, pois a valorização do uso de textos de circulação social, bem como de textos reais, isto é, textos que fazem parte da realidade dos alunos, tais como, bilhetes, notícias de jornais, músicas, cantigas de roda, parlendas, poemas, dentre outros, permitem uma prática de escrita voltada para a perspectiva do 
letramento. Compreendemos que o conhecimento acerca da concepção de linguagem que fundamenta o processo da produção de texto nessa perspectiva é indispensável para o trabalho do professor em sala de aula.

Nesse sentido, ressaltamos que a prática da escrita na formação do professor não é uma tarefa fácil. Este profissional, quando ingressa na universidade, depara-se com várias exigências de escrita, bem diferentes daquelas vivenciadas na escola. Silva (2012) critica a prática de escrita no contexto acadêmico, exemplificando que se as disciplinas constituem comunidades discursivas diferentes, os modos como os gêneros escritos se apresentam terão diferenças retóricas que refletem a identidade disciplinar destes campos do saber" (SILVA, 2012, p. 98). Ressalta que $\mathrm{o}$ ato de escrever necessita ser compreendido numa perspectiva interacional, uma prática social situada e particularizada, opondo-se a essa visão de escrita acadêmica, homogênea e considerada como uma habilidade geral. De acordo com esse autor, a prática da escrita na formação do professor deve ser discutida como uma prática social situada e realizada por diferentes disciplinas, não somente em língua portuguesa.

Desse modo, considerar a escrita "como uma habilidade linguística geral aprendida na educação básica, aplicável e adaptável a qualquer demanda de escrita futura em qualquer situação retórica letrada" (SILVA, 2012, p. 99), implica num olhar bastante limitado da perspectiva do letramento. $\mathrm{O}$ autor assevera que o ato de escrever faz parte de um processo contínuo que se desenvolve por toda a vida, não havendo uma habilidade geral que proporcione ao sujeito escrever com proficiência e fluentemente sobre qualquer assunto, em qualquer contexto social. 
Nesse contexto, a prática da escrita ocorre já no ingresso dos cursos de graduação, um processo que é marcado pela continuidade e pela ruptura com práticas de escrita escolar. Quando falamos em continuidade, queremos assinalar que o processo de ensino e aprendizagem continua embasado por elementos didáticos, pedagógicos e avaliativos, em cujo processo, o professor continua sendo o principal interlocutor da escrita desse aluno. Quando falamos em ruptura, nos referimos aos saberes que precisam estar de acordo com as normas do discurso acadêmico:

Citação de fontes, gerenciamento de vozes no texto, uso de diferentes metodologias, sanções contra plágio etc. A ruptura também se manifesta nos novos gêneros que os alunos eventualmente terão de ler e produzir: artigos científicos, ensaios, resenhas, monografias, relatórios de pesquisa ou de estágios, fichamentos etc. (SILVA, 2012, p. 106).

Considerando essas questões, Silva defende o seu ponto de vista, enfatizando que a escrita na universidade não é homogênea. O letramento acadêmico se diferencia devido à disciplinarização dos saberes, estabelecidos por um determinado curso, pelos professores e seus alunos. Do ponto de vista do autor, o grande desafio por parte dos professores que ensinam a escrever é não aceitar esse ensino como uma habilidade geral e acreditar que a escrita acadêmica se configura como uma prática socialmente situada. Esta prática deveria responder, portanto, a diferentes exigências contextuais (disciplinares) e a diferentes 
regras de interação entre os alunos de uma dada turma e seus professores.

Situando o sujeito-professor, alvo de nossa pesquisa, no contexto de sua formação, temos que a professora possui graduação em Pedagogia. Sabemos que os cursos de Graduação, de modo geral, trabalham uma orientação de letramento acadêmico cujo desenvolvimento de uma prática de escrita socialmente situada favorece de modo insuficiente a motivação do graduando em formação e/ou o professor em formação continuada a desenvolver o gosto pelo escrever. Configura-se, então, como uma prática que trabalha a escrita com uma habilidade geral, orientada por normas básicas que funcionam em cada gênero de texto acadêmico, específico de cada disciplina.

Em meio a esse contexto histórico, percebemos que há ainda, de modo geral, uma desarticulação entre o modo como circula a escrita no cotidiano de cada um, na sociedade e o modo escolar como a escrita se inscreve. Além desse contexto, há a se considerar a história individual do processo de letramento. Como já vimos sinalizando, acerca do tema de nossa pesquisa, em sentido amplo, - lugar do sujeito-professor na escrita de textos -, trazemos para evidência da análise, nesse artigo, os dados que atendem à nossa questão motivadora e aos objetivos a ela articulados. Precisamos esclarecer que, para efeito de análise, utilizamos a seguinte sinalização: Pesquisadora (P) e Professora do Ensino Fundamental I (PA). 


\section{Uma breve análise}

A história da escrita na vida da professora:

o que revelam os discursos

Iniciamos nossa coleta de dados com uma entrevista de caráter informal, seguida de um relato escrito, contendo as mesmas perguntas da entrevista. Esses instrumentos objetivaram coletar informações sobre como a professora aprendeu a ler e a escrever; sobre a sua relação com o ato de escrever em seu cotidiano e sobre o modo como essa prática de escrita reflete-se na forma como ensina a escrita, na turma do $1^{\circ}$ Ciclo Final ( $3^{\circ}$ ano). Essas informações materializam o(s) discurso(s) construído(s) nesses espaços discursivos, processo que se configura por movimentos de autoria da professora, como sujeito de discurso. Assim, reproduzimos, a seguir, alguns fragmentos desses dois instrumentos:

\section{RECORTE I}

P: Como você aprendeu a escrever?

PA: Processo que eu não lembro como foi o que aconteceu com a leitura e a escrita. Eu não lembro o que foi que aconteceu. Eu lembro da professora, a primeira professora... eu lembro, mas não sei se aprendi a ler ou a escrever com ela. Eu sei que a primeira vez que fui para a escola, eu já passei de série, 1a, 2a, 3a e 4a. Eu já pulei a primeira série, eu já passei 
para uma segunda série. Então, aí eu já sabia ler. Como isso aconteceu, eu não lembro. (Professora do Ensino Fundamental I. Entrevista, $1^{\mathrm{a}}$ pergunta. Apêndice, A, p. 98).

\section{RELATO ESCRITO (trecho inicial)}

P: Elabore um relato escrito, descrevendo e narrando sua experiência com a prática de escrever textos.

PA:Pensando a minha fase de estudo, ou seja de escola, parte dela não consigo lembrar. Lembro com saudade de minha primeira professora, e que entrei na escola aos sete anos, idade em que era permitido entrar para a escola. Entrando na escola lembro vagamente que já sabia escrever e ler, porém não lembro como se deu esse processo, inclusive passei logo para a segunda série (...).

(Professora do Ensino Fundamental I. Relato escrito, trecho inicial. Apêndice, B, p. 99).

Relacionando o dizer expresso no recorte I da entrevista com o dizer expresso no trecho inicial do relato escrito, produzidos pela professora, percebemos que apresentam dados que se articulam, sendo o relato a materialização na escrita, das informações prestadas na entrevista, como a confirmar o discurso sobre como entendia seu processo de inserção no mundo da escrita. Nesses dizeres, destacamos 
o discurso que a professora evidencia sobre as lembranças de sua primeira escola e de sua experiência inicial com a escrita. Ao afirmar que já "sabia escrever e ler", traz no seu dizer o sentido de valorização dessa habilidade, como uma aquisição que se dá como um "fenômeno", que não se explica, acontece.

Um outro discurso que destacamos é a referência a um certo "esquecimento" por parte da professora em relação a como se deu o seu processo de aquisição da leitura e da escrita. Ela lembra da sua primeira professora, contudo, não consegue explicar se foi com essa professora que aprendeu a ler e a escrever. Esse "esquecimento" retoma dois tipos de esquecimentos do sujeito-falante, trazidos por Pêcheux ([1975] 2009). O esquecimento número um diz respeito à ilusão que o sujeito-falante tem de ser a origem do seu dizer. Está relacionado ao inconsciente e também pode ser chamado de esquecimento ideológico, uma vez que não é determinado pela nossa vontade, mas pelo modo como somos afetados pela ideologia. O esquecimento número dois ${ }^{3}$ está relacionado ao consciente e pertence à ordem enunciativa. $\mathrm{O}$ sujeito-falante aqui tem a impressão da realidade do pensamento, ou seja, acredita que o que é dito só pode ser dito com aquelas palavras e daquela forma.

Colocando-se como sujeito de discurso, a professora situa-se num campo amplo de sentidos, e vai buscar esses

3 Refere-se ao "esquecimento pelo qual todo sujeito-falante "seleciona" no interior da formação discursiva que o domina, [...] um enunciado, forma ou sequência, e não um outro, que, no entanto, está no campo daquilo que poderia reformulá-lo na formação discursiva considerada" (PÊCHEUX, [1975] 2009, p. 173). 
sentidos no interdiscurso, isto é, na memória discursiva, que "sustenta o dizer em uma estratificação de formulações já feitas mas esquecidas e que vão construindo uma história de sentidos. É sobre essa memória, de que não detemos o controle, que nossos sentidos se constroem" (ORLANDI, 2013, p. 54). Então, toda produção de discurso e sentidos, historicamente produzidos pela sociedade e dos quais nos apropriamos no momento de enunciar ou escrever, é o que sustenta os nossos dizeres.

Neste caso, a professora está falando de dois tipos de memória: a memória a curto e longo prazo, que se refere à nossa memória cerebral, às nossas lembranças e à memória discursiva, que faz referência a um discurso sobre processo de aquisição de leitura e escrita, processo não lembrado, instaurado no não-dito do discurso. Esse remeter da professora às suas memórias e ao interdiscurso nos faz pensar que provavelmente o seu processo de alfabetização não tenha sido algo importante, significativo para ela.

Mas, que pode ter sido algo penoso, traumático, talvez pela forma como foi ensinada, que faz com que ela "apague" suas lembranças e revele em seu discurso "eu não lembro o que foi que aconteceu. Eu lembro da professora, a primeira professora [...] eu lembro, mas não sei se aprendi a ler ou a escrever com ela".

A professora enuncia-se a partir do "eu" no discurso, sua enunciação organiza-se na oralidade, e fala da primeira professora e da escola onde estudou, como um lugar que não significou, "eu já passei de série, 1a, 2a, 3a e 4a . Eu já pulei a primeira série, eu já passei para uma segunda série. Então, aí eu já sabia ler. Como isso aconteceu, eu não lembro". Na concepção da PA, o processo de aquisição de 
escrita é concebido como algo muito rápido, automático e até mecânico. Essa explicação remete à noção do aprender a ler como processo que é automático: o aluno começa a decifrar o código, "de repente", começa a ler! Explicação fundamentada na tradição escolar, na concepção de sujeito pensado no contexto do behaviorismo, que aprende ao responder a estímulos a ele apresentados repetidamente.

A professora finaliza o seu dizer reforçando a repetição de algo que não lembra, sustentando o sujeito da enunciação, ancorando-o, e ele não perde o controle sobre o seu dizer, evidenciando uma ação de letramento, ou seja, PA tem a experiência de se posicionar falando, deixando marcas materializadas na língua, "eu não lembro", repetidas vezes, que sinalizam os movimentos de autoria, seu discurso revela em seu dizer a sua subjetividade e finaliza a sua enunciação reforçando a sua inquietude em relação a algo que não consegue dizer: o fato de não ter lembrado como ocorreu esse processo.

Focalizando o trecho do relato escrito, PA confirma as informações acerca de como ocorreu o seu processo de leitura e escrita. Inicia seu texto, situando-se a partir do "eu" no discurso. Elabora toda a sequência enunciativa, conforme a memória discursiva das lembranças, trazendo em seu dizer, agora no relato escrito, marcas do imaginário coletivo acerca da primeira professora: "lembro com saudade de minha primeira professora", apresentando um discurso de valorização do profissional que, a partir da contemporaneidade tem perdido esse lugar de reconhecimento. O movimento de autoria da professora como sujeito de seu texto desloca-se de dois lugares específicos da enunciação: oral e escrito, apresentando controle do seu dizer sobre suas lembranças. 
Apresentamos, em seguida, outra questão extraída da entrevista que focaliza um outro aspecto que se relaciona à história da prática de escrita da professora.

\section{RECORTE II}

P: Gosta de escrever?

PA: gostar de escrever não é bem a minha questão...gostar de escrever. $\mathrm{Eu}$ gosto mais de uma conversa, um debate do que a própria escrita, a escrita propriamente dita, não é muito a minha praia, mas que produzo alguma coisa.

(professora do Ensino Fundamental I. Entrevista, $2^{a}$ pergunta. Apêndice, A, p. 98).

P: Como é que essa escrita se faz no seu dia a dia?

PA: Com certeza a escrita está no meu dia a dia, na produção diária, no relato das crianças, produção do ensino textual. Como acontece, eu faço a partir de uma figura para que eles vão produzindo, depois eles vão criando seus próprios textos.

(professora do Ensino Fundamental I. Entrevista, $4^{\mathrm{a}}$ pergunta. Apêndice, A, p. 98).

P: E fora desse ambiente de trabalho como você percebe sua escrita?

PA: em casa com minha filha, na produção de texto para a escola. 
Então, ajudo a produzir, aí acontece a escrita, na produção de texto.

(professora do Ensino Fundamental I. Entrevista, $5^{a}$ pergunta. Apêndice, A, p. 98).

\section{RELATO ESCRITO (trecho final)}

P: Elabore um relato escrito, descrevendo e narrando sua experiência com a prática de escrever textos.

PA: A prática de escrita não é muito fácil, sinto algumas dificuldades em produzir textos, relatar fatos escritos, mas não desgosto totalmente, até porque no meu dia-a-dia é preciso usar a escrita, tanto no trabalho com relatórios, registros de aulas e preparar aulas. No meu dia-a-dia em casa também preciso usar a escrita quando faço uma lista de compras, ou preciso ajudar minha filha com as tarefas, no mais a escrita está presente no nosso dia-a-dia. Em minha profissão a escrita não pode ficar de fora do contexto da sala de aula. (professora do Ensino Fundamental I. Relato escrito, Trecho final. Apêndice, B, p. 99).

Ao analisar recortes da entrevista e o trecho final do relato escrito, observamos que há referência a um discurso escolarizado sobre a instituição da escrita (FD), como domínio obrigatório do sujeito profissional, professor. 
A professora se contradiz no momento em que enuncia "gostar de escrever não é bem a minha questão [...] a escrita propriamente dita, não é muito a minha praia, mas que produzo alguma coisa". Essa contradição caracteriza o modo como o sujeito de discurso se movimenta na enunciação. Ela é interpelada pela posição de ser professora, fazendo com que a formação discursiva determine o que ela pode e deve dizer, ou seja, a partir do lugar social que ela ocupa - a sala de aula. Percebemos também que, no relato escrito, o sujeito nessa formação discursiva é interpelado pelas relações de poder, pois a escola, enquanto aparelho ideológico, a interpela a dizer que, em seu dia a dia produz escrita, tendo em vista que a profissão docente está intrinsecamente relacionada ao ato de escrever: "em minha profissão a escrita não pode ficar de fora do contexto da sala de aula" (Relato escrito da professora). Esse dizer da professora confirma que a escrita em seu cotidiano está voltada apenas para o contexto acadêmico, sua prática de escrita é estritamente profissional e escolarizada, desse modo, a professora revela uma concepção de escrita formal, enquanto domínio do código escrito.

Essa noção se faz representar na concepção de texto e de linguagem enquanto domínio do código escrito, reveladas em seu discurso, ao responder perguntas do questionário. Sobre a concepção de texto, diz que texto é um "conjunto de frases que é feito para ser lido e entendido oralmente ou escrito" (Entrevista, questão 16). Sobre a concepção de linguagem, explica que linguagem "é a forma a qual podemos expressar nossas ideias e pensamentos através da fala ou da escrita" (Questão 17). Esses enunciados revelam que a professora concebe o texto sob a orientação da tradição escolar, como uma sequência de 
frases para formar uma unidade com início, meio e fim. Seguindo essa orientação, a linguagem é considerada como expressão de pensamento, em que o sujeito é visto individualmente, não priorizando a interação social, lugar de constituição da linguagem e do sujeito.

Acerca de como acontece o ensino da escrita, de como é sua prática para escrever texto em sala de aula, a professora revela:

\section{RECORTE III}

P: Pensando profissionalmente. Como poderia falar sobre o ensino da escrita em sala de aula? Como é que acontece o ensino da escrita? De produção de texto. Como é sua prática para escrever texto em sala de aula?

PA: Tenho que escrever a escrita. Bom a minha prática, parte de texto, de leitura, de poemas, que é a parte que eu mais gosto, do poema para trabalhar para que depois eles partam dos seus próprios poemas e vá gostando de outras produções escrita, poesia, poemas....euh! uma narrativa, fábula, daí, tudo, a partir da escrita.

(professora do Ensino Fundamental I. Entrevista, $7^{\mathrm{a}}$ pergunta Apêndice, A, p. 98). 
Consideramos, nesse recorte, que a professora ensina a prática de escrever texto em sala de aula, numa perspectiva de texto do ponto de vista da tradição escolar, em que é necessário um modelo já pronto. Não compreende a prática de escrita numa perspectiva discursiva, em que a produção de sentidos é realizada por sujeitos situados sócio-historicamente. Esse discurso do ensino, pautado em modelos, provavelmente, fundamenta-se na sua formação que não prioriza pensar o ensino a partir do que o sujeito sabe, do que o sujeito conhece.

Percebe-se que sua prática de ensino da escrita parte da ideia de que é necessário dominar o código escrito primeiramente, como prioriza a linguística tradicional: prioriza-se o código, enfatiza-se a letra, o ponto de partida é a letra para depois se trabalhar com as sílabas, geralmente, associadas a uma palavra ilustrada. Ensino, então, descontextualizado, cujo foco é o professor como detentor desses saberes e o aluno, sujeito que precisa ser estimulado a partir de modelos para recuperar e perpetuar o que esses modelos apontam como "ideal" para se aprender a escrever.

Observando as questões dos recortes II e III e a produção I, acerca de como a professora fala da escrita, percebemos que existem modos de dizer que fortalecem um discurso de escrita como obrigação, de escrita escolarizada, uma vez que ela enuncia desde a primeira pergunta "gostar de escrever não é bem a minha questão [...] mas que produzo alguma coisa". A fala da professora revela indícios de que a escrita em seu dia a dia se constitui como obrigação, já que ela é um sujeito professor que se utiliza da linguagem "com certeza a escrita está no meu dia a dia, na produção diária, no relato das crianças, produção 
do ensino textual [...] em casa com minha filha, na produção de texto para a escola", e ao finalizar o relato escrito "Em minha profissão a escrita não pode ficar de fora do contexto da sala de aula". Assim, esses dizeres materializam um discurso. A professora mostra como é que ela se movimenta de um lugar de sujeito de discurso falando, para um lugar de sujeito de discurso escrevendo, sendo coerente com o mesmo ponto de vista, evidenciando o discurso da escrita numa perspectiva escolarizada.

A professora se instaura nesse discurso, tanto para elaborar o seu texto oral como o texto escrito e se organiza nessa (FD). Ao utilizar os mecanismos linguísticos "mas $[\ldots]$ " “com certeza $[\ldots]$ ", a professora está tentando modalizar o seu dizer, trazendo um discurso dito, "em casa com minha filha $[. .$.$] " "Em minha profissão a escrita não pode$ faltar $[\ldots . .]^{\prime \prime}$, o da obrigação, que dialoga com outro não dito: profissão de professor requer domínio da escrita, logo, ser professor significa saber escrever. Ao fazer essa relação entre o dito e o não dito, a professora se constitui subjetivamente como sujeito e se coloca como sujeito de autoria, uma vez que está se responsabilizando pelo que está dizendo.

Nesse sentido, observa-se que a professora evidencia, em sua relação com a prática escrita, sua concepção de texto, de linguagem e do que é escrever, confirmando em seu discurso o que faz em sua prática na sala de aula. Revela seu discurso, como essa dificuldade que possui com a prática do escrever e esse modo de conceber a linguagem escrita, numa perspectiva tradicional, orientam o modo como ela ensina a escrever na sala de aula. São eventos de letramento escolarizado, baseados numa visão da tradição escolar, em que se prioriza o uso do código. 
Percebemos que o sujeito de discurso - alvo de nosso estudo - a professora do $1^{\circ}$ ciclo final ( $3^{\circ}$ ano " $\left.\mathrm{B}^{\prime \prime}\right)$ - apresenta suas concepções sobre a prática da escrita, e, a partir dela, entende ser o seu cotidiano nas experiências sofre as interpelações de condições de produção, fruto de sua formação profissional de base tradicional e formal (perfil que poderemos visibilizar na atividade de sondagem que se segue no quadro apresentado abaixo).

\section{Na sala de aula}

Apresentamos, nessa abordagem analítica, dados da professora e de sua sala de aula, seguidos de uma demonstração em quadro de uma proposta didática de aula de língua materna, desenvolvida pela referida professora e observada por nós, na etapa da coleta de dados que se configurou como sondagem para nos situarmos nas condições de trabalho e de produção de sentidos de que faziam parte nosso sujeito de pesquisa e sua sala de aula. Nosso objetivo, ao trazer esses dados, é tecer uma articulação entre o dizer (discurso) da professora na entrevista, no questionário e no relato escrito e sua atuação no ensino da língua materna. Movimento discursivo do sujeito que evidencia a interpelação das concepções com as quais a professora se identifica e das quais se apropria para direcionar suas ações.

\section{A professora e sua proposta de aula de língua materna}

O sujeito dessa pesquisa é professora do ensino fundamental I há doze anos. Graduou-se em Licenciatura Plena em Pedagogia, na Universidade Estadual Vale do Acaraú 
- UVA, no ano de 2001, não possui pós-graduação e tem vinte e oito anos de tempo de serviço. Participa do curso de formação continuada - PNAIC, desde o seu início em Campina Grande- PB, no ano de 2013.

Como sujeito de pesquisa, a professora teve como interlocutor - o outro - nas suas experiências com a prática de escrita, sua turma do $1^{\circ}$ Ciclo Inicial $\left(3^{\circ}\right.$ ano) do ensino fundamental I de uma escola da cidade de Campina Grande/PB. Essa turma é composta por trinta e um alunos, oriundos de um bairro periférico dessa cidade, com um baixo nível sócio-econômico, muitos deles pertencem a famílias, cujos pais são analfabetos ou semi-analfabetos. Alguns pais não possuem renda fixa, pois trabalham na reciclagem e sobrevivem com o auxílio dos programas do Governo Federal, a exemplo do Bolsa Família. Desse universo, quatro alunos não estão alfabetizados, cinco alunos estão em processo de aprendizagem do SEA - Sistema Alfabético de Escrita e os demais estão alfabetizados.

Nessa turma, a professora desenvolveu a seguinte proposta de trabalho com a língua materna, no ensino da leitura e da escrita. Proposta que foi observada e devidamente registrada (gravações em áudio e, posteriormente, transcritas). Importante esclarecer que todos os dados coletados foram devidamente autorizados pela professora e gestora da escola onde ocorreu a pesquisa, em sua maior parte. Autorização que recebeu a liberação do Comitê de Ética da UEPB, em cujo Mestrado em Formação Profissional/MFP a mestranda era vinculada. 
Proposta de aula de lingua materna

(etapa inicial da pesquisa)

Quadro 3 - Etapa I- Observação de aulas de língua portuguesa

\begin{tabular}{|c|c|}
\hline 02 de marco de & $\begin{array}{l}- \text { go } \\
\text { em } \\
\text { Lino }\end{array}$ \\
\hline $\begin{array}{l}2^{\text {a }} \text { Observação } \\
03 \text { de março de } \\
2015\end{array}$ & $\begin{array}{l}\text { amática - Encontros Vocálicos; } \\
\text { itura do livro de literatura: A noite e o dia (Eunice }\end{array}$ \\
\hline $\begin{array}{l}05 \text { de março de } \\
2015\end{array}$ & He \\
\hline $4^{\mathrm{a}}$ Observação & itura do livro de literatura: Hoje é amanhã? \\
\hline $5^{\mathrm{a}}$ Observação & $\begin{array}{l}\text { Atividade: Leitura e escrita de palavras com: br, } \\
\mathrm{dr} \text {, fr, gr, pr, tr, vr; }\end{array}$ \\
\hline & \\
\hline $6^{\mathrm{a}}$ Observação & \\
\hline & ua \\
\hline & $\begin{array}{l}\text { rtir de uma imagem, pesquisada no dia anterior: } \\
\text { ofessora e pesquisadora participaram, produzindo } \\
\text { da uma, sua produção escrita; }\end{array}$ \\
\hline
\end{tabular}


$8^{\text {a }}$ Observação

participante

23 de março de 2015
Pesquisa de leitura: Realização de uma pesquisa com a turma, sobre os gêneros textuais que gostariam de ouvir, ler e escrever;

Descrição resumida das aulas de língua portuguesa na turma do $1^{\circ}$ Ciclo Final ( $3^{\circ}$ ano "B"- manhã), Ensino Fundamental I de uma Escola Municipal, na cidade de Campina Grande-PB.

As atividades de leitura e de escrita, acima descritas resumidamente, revelam que a professora concebe a língua materna numa abordagem de linguagem como instrumento de comunicação, acreditando que o ato de se comunicar é algo individual, não havendo relação com o meio social nem com a história de vida dos alunos. Com base nessa concepção de linguagem, ensina que para ler e escrever é necessário apenas dominar a gramática normativa. Isto se confirma nas atividades de letramento que utiliza, tais como: atividades para trabalhar o código escrito, destacando as letras de maneira isolada, o estudo das sílabas; atividades de leitura de frases e dos livros.

A concepção de linguagem adotada pela professora nos revela, em sua metodologia de ensino, uma concepção de língua como um código, um instrumento de comunicação e o texto como um produto a ser decodificado pelo leitor. Esse modo de se situar no ensino, como professora de linguagem, revela que a professora entende que ser professor é dominar e transmitir conhecimentos, é aquele que dá ordens, que prescreve, que parte de um modelo pronto e acabado para ensinar, evidenciando assim uma concepção tradicional de professor. E ser aluno é aquele que assume uma postura passiva, que está naquele espaço para obedecer, ouvir e executar as atividades, independentemente 
das práticas sociais de uso da linguagem. Por outro lado, aprender a escrever, nessa concepção revelada pela professora, é decodificar e memorizar as letras, as sílabas, para posteriormente poder escrever frases e produzir textos, evidenciando assim, uma perspectiva linear do processo de escrita.

É possível, então, perceber que as concepções de ser professor de língua materna, de linguagem, evidenciadas nas suas colocações seja na entrevista, no questionário e no relato escrito acerca da noção de texto e de leitura estão fundamentando a focalização que dá para o ensino da leitura, da escrita em língua materna. São concepções das quais se apropriou no processo de construção do sujeito da/na educação escolar que "falam" (discurso ideológico), sobre um modo de ser professor e aluno e como se configura o ensino que leva à formação de seus alunos, nessa etapa da escolarização.

\section{Considerações finais}

Esse artigo procura trazer reflexões em torno da seguinte questão: De que modo a vivência com a prática de escrita da professora, no seu cotidiano, revela concepções que fundamentam a direção dada ao ensino da produção escrita na sala de aula? Esse estudo mostrou que nem sempre o professor está consciente da concepção de linguagem que embasa a sua prática de ensino de língua materna. Por outro lado, evidencia nos dados que analisa, produzidos pelo ponto de vista da professora, sujeito da pesquisa, que as noções de linguagem, sentido, texto escrito, sujeito se constituem no escopo da tradição que concebe o estudo voltado para a língua, enquanto sistema 
imanente, homogêneo. São noções que se historicizaram na instituição escolar e perduram, evidenciando seu lugar de poder.

Procurando evidenciar, através da Análise de Discurso de linha francesa (AD), concepções relacionadas ao sujeito de discurso, texto escrito, sentidos e linguagem que rompem com essas noções teóricas institucionalizadas, esse estudo procura refletir sobre as implicações desse discurso oficial. A ausência da renovação e ressignificação desse conhecimento interfere consequentemente no modo como o docente desenvolve o processo de ensino e aprendizagem, bem como a sua formação profissional.

Esse efeito de sentido revela que o sujeito não é a origem do seu dizer, tendo em vista que nosso discurso está sempre relacionado ao lugar social de onde falamos. Desse modo, o sujeito de linguagem e de sentidos, ao enunciar o seu discurso, é afetado pelo lugar social que ocupa, pela história e ideologia.

Evidenciamos que o lugar da escrita no processo de formação da professora revelou que o ato de escrever em seu cotidiano estava voltado para o ponto de vista da tradição escolar, em que se considera o texto como uma sequência de frases para formar uma unidade com início, meio e fim, não considerando a linguagem como um processo de interação, mas como expressão de pensamento, em que o sujeito é visto individualmente, não priorizando a interação social, lugar de constituição da linguagem e do sujeito.

Essa experiência revela, portanto, a necessidade que tem o professor de língua materna em vivenciar práticas de letramento, que considerem o ensino do escrever dentro de um contexto social, com textos veiculados socialmente, 
fazendo parte das relações comunicativas dos sujeitos efetivamente. Podemos acrescentar que essa experiência completa está descrita e documentada na Dissertação de Mestrado "Professora escrevendo em sala de aula: um outro modo de fazer 'uma formação continuada', da qual recortamos uma etapa inicial desse trabalho.

Esse trabalho realizado em forma de projeto de intervenção procurou experienciar a possibilidade de refletirmos sobre o fato que nos motivou a estudá-lo: aprende-se a escrever, escrevendo, bem como ensina-se a escrever, aquele que faz do escrever uma prática cotidiana. Também é fato que escrever textos como uma prática, e gostar de escrever são requisitos não tão "naturais", pensando em nossa realidade social, inclusive, escolar. Esse domínio e uso depende, entre outros fatores, das condições e dos objetivos do sujeito que precisa fazer uso da escrita.

\section{Referências}

BEZERRA, Maria Auxiliadora. A escrita em contexto de formação continuada: objeto a aprender e objeto a ensinar. In: SIGNORINI, Inês (Org.). Significados da inovação no ensino de língua portuguesa e na formação de professores. Campinas, SP: Mercado de Letras, 2007, p. 147 - 170.

BRANDÃO, Helena H. Nagamine. Introdução à análise do discurso. 2. ed. Campinas, SP: EDUNICAMP, 2004.

FERNANDES, Cleudemar Alves. Análise do discurso: reflexões introdutórias. 2. ed. São Carlos, SP: Claraluz, 2008. 
KLEIMAN, Angela B. Letramento e formação do professor: quais as práticas e exigências no local de trabalho? In: KLEIMAN, Angela B. (Org.). A formação do professor: perspectivas da linguística aplicada. Campinas, SP: Mercado de Letras, 2001, p. 39 - 69.

LEANDRO, Maria de Lourdes da Silva. A produção de texto: teoria e ensino - um possível diálogo. In: SOUSA, Maria Ester Vieira; ASSIS, Maria Cristina (Org.) Pesquisa em língua portuguesa: da construção do objeto à perspectiva analítica. João Pessoa: UFPB, 2011, p. 105 - 136.

ORLANDI, Eni Puccinelli. Análise de discurso: princípios e procedimentos. 2. ed. Campinas, SP: Pontes, 2013.

ORLANDI, Eni Puccinelli. Discurso e leitura. 9. ed. São Paulo: Cortez, 2012a.

ORLANDI, Eni Puccinelli.. Discurso e texto: formulação e circulação dos sentidos. 4. ed. Campinas, SP: Pontes, 2012b.

PÊCHEUX, Michel. Semântica e discurso: uma crítica à afirmação do óbvio. Tradução: Eni Puccinelli Orlandi et al. 4. ed. Campinas: Unicamp, [1975] 2009, p. 129 - 168.

SILVA, Marcelo Clemente. Gêneros da escrita acadêmica: questões sobre ensino e aprendizagem. In: REINALDO, Maria Augusta; MARCUSHI, Beth; DIONISIO, Angela (Orgs.). Gêneros textuais: práticas de pesquisa e práticas de ensino. Recife: Ed. Universitária da UFPE, 2012, p.97 -115 . 



\title{
A LEITURA NA EDUCAÇÃO DE JOVENS E ADULTOS
}

\author{
Rosely de Oliveira Macário ${ }^{1}$ \\ Linduarte Pereira Rodrigues ${ }^{2}$
}

\section{Introdução}

Num cenário de elevados índices de alunos não escolarizados, vale destacar a Educação de Jovens e Adultos (EJA), composta por sujeitos sociais que, ao longo de suas vidas, registram uma história de insucesso escolar. Por outro lado, a própria história da EJA tem se constituído numa modalidade educativa que tem respondido secundariamente às expectativas e às necessidades da demanda escolar, para a qual ela se destina, o que é motivado pela insuficiência do acesso e pela inadequação de propostas curriculares existentes que traduzem uma concepção

1 Doutora em Educação pela Universidade do Estado do Rio de Janeiro. Professora de Língua Portuguesa da Educação Básica da Rede Pública do Estado da Paraíba. Grupo de Pesquisa: Teorias do sentido: discursos e significações. Campina Grande, Brasil; roselymacario@hotmail.com

2 Doutor em Linguística pela Universidade Federal da Paraíba. Professor do Departamento de Letras e Artes e do Programa de Pós-Graduação em Formação de Professores da Universidade Estadual da Paraíba. Grupos de Pesquisa: Memória e imaginário das vozes e escrituras; Linguagem, interação, gêneros textuais e ou discursivos; Teorias do sentido: discursos e significações. Campina Grande, Brasil; linduartepr@gmail.com 
segmentada e reducionista do conhecimento. Ao mesmo tempo, continua a controvérsia no que tange à problemática do ensino da língua materna no país, e na envergadura dessas discussões se observa que o ensino da leitura tem se constituído motivo de preocupação na prática de sala de aula na Educação Básica, quando não encara o fato de que este ensino não vem garantindo a formação de leitores com habilidades e competências para usar a leitura nos diferentes contextos sociais.

Geraldi (2013, p.28) nos adverte para o fato de que "a língua, enquanto produto desta história presente, vem marcada pelos seus usos e pelos espaços sociais destes usos". Assim, defende o ensino da língua não como produto pronto e acabado, mas, sobretudo, como produto histórico inacabado, em processo de construção interlocutiva nas diferentes instâncias sociais de uma dada formação social. Entretanto, a realidade de sala de aula, quando nos reportamos ao ensino da leitura, geralmente, desenha práticas escolares em conformidade com a concepção de língua como sistema abstrato de regras, com propostas de atividades dissociadas de situações sociocomunicativas entre os interlocutores em diferentes contextos sociais (GERALDI, 2011).

Frente a esse problema recorrente, nosso estudo sugere tomar a língua como atividade de interação entre dois ou mais interlocutores, enfatizando a satisfação dos alunos da EJA no atendimento às suas necessidades leitoras, tanto na vida escolar quanto na vida cotidiana, em que os gêneros textuais figuram como práticas sociais. Diante disso, realizamos uma pesquisa com foco na formação de leitores da Educação Básica: um estudo que versa sobre a ação docente na EJA, suas implicações teóricas e pedagógicas, 
no que refere ao ensino de leitura numa perspectiva de inclusão social. Em nosso estudo, observamos que pensar a prática de leitura na sala de aula da EJA nos remete a refletir acerca do trabalho docente, do perfil dos alunos, dos aspectos motivacionais que resultaram nessa busca pela escolarização, bem como sobre as ações pedagógicas atreladas às exigências da sociedade contemporânea, em que se faz necessário ressignificar o ensino da língua materna, sob o foco da leitura nos diversos usos e função social, em diferentes contextos socioculturais.

A nossa pesquisa insere-se no quadro de estudos de abordagem qualitativa, do tipo etnográfico, pesquisa-ação, focada na descrição e análise das práticas de letramento de uma sala de aula de $1^{\circ}$ ciclo inicial e final da EJA, rede pública de Campina Grande-PB. Teve como objetivo geral: evidenciar práticas de letramento escolar na sala de aula da EJA a partir da leitura de revistas de circulação nacional, com ênfase para a sobrevivência dos alunos na cultura marcadamente letrada. Buscamos, num trabalho com revistas, disponibilizar ao aluno da EJA ações didáticas que o estimulassem como leitor/trabalhador que concebe a leitura numa perspectiva de entender o sentido do texto, indo além do processo de decodificação.

Utilizamos a abordagem sócio-interacionista e discursiva, com vistas ao entendimento da dinâmica de sala de aula na EJA, bem como do uso e funções das práticas de leitura por parte dos participantes da investigação. Neste sentido, nosso referencial teórico tem como base os estudos sobre a prática de leitura e o ensino de língua materna ancorados em Rojo (2009a; 2009b), Kleiman (1999), Pinto (2007), Bronckart (2001), Orlandi (1998), Geraldi (2011; 2013), Freire (1994), Rodrigues (2012), Bortoni-Ricardo 
(2011), Barbier (2002), Antunes (2009), Brunel (2008), Mollica e Leal (2012), Schneuwly e Dolz (2011), Signorini (2004), Soares (1998); selecionados mediante ao entendimento da identidade dos participantes da pesquisa, formada em diferentes contextos sociais, os quais, motivados pela exigência da cultura letrada, procuraram a escola noturna para aprender a ler.

A partir desse direcionamento inicial, destacamos que a leitura só desperta interesse quando interage com o leitor, e faz sentido quando se articula com as informações que já são conhecidas, pois a leitura não é um ato solitário, mas, como endossa Zilberman (2005), é interação verbal entre indivíduos socialmente determinados. Nestes moldes, pensar a leitura, especificamente na EJA, sugere disponibilizar ao aluno/leitor oportunidades de reflexões e usos da linguagem, de forma a contribuir com o processo de ensino-aprendizagem dos alunos.

\section{Tecendo caminhos para ensinar o aluno a ler na EJA}

Na discussão sobre a EJA, em relação ao domínio do código linguístico e pensando nos inúmeros desafios da atualidade, no que concerne à garantia do acesso, permanência e continuidade do aluno dessa modalidade de ensino na escola; vemos, portanto, que cabe ao docente da Educação Básica ressignificar suas ações didáticas quanto à sistematização de atividades desafiadoras e significativas que estimulem o aluno trabalhador a permanecer na sala de aula, tendo como preocupação a formatação de ações educativas que contemplem os interesses, necessidades e especificidades dessa demanda escolar, constituída 
de pessoas excluídas, ao longo da trajetória da história da educação brasileira, do direito à educação de qualidade.

Diante do exposto, ao pensar o ensino de leitura na Educação Básica da EJA, não se pode desconsiderar o que diz respeito aos conceitos fundamentais para o ensino da Língua Portuguesa. Destacamos que, atualmente, a linguagem é concebida como forma de ação interativa. Geraldi (2013, p.91) explica que se trata “[...] de um jogo que se joga na sociedade, na interlocução, e é no interior de seu funcionamento que se podem estabelecer as regras de tal jogo". E, ainda, percebe-se também o ensino da leitura e da escrita mediante o uso de diferentes gêneros textuais. Cabe, portanto, à escola viabilizar o acesso do aluno ao universo de textos que circulem socialmente, ensinar a produzi-los e interpretá-los (BRASIL, 1997).

Kleiman (2001) explica que muitos alunos que estão na EJA trazem histórias de práticas desmotivadoras, de concepção inadequada com o livro. Nesse contexto, observa-se que ainda há muitas práticas docentes sedimentadas em imagens negativas sobre o livro e a leitura desse aluno, que logo passa a ser mais um leitor em formação, como também considerando que muitos alunos, no contexto da EJA, refletem uma diversidade de contextos de aprendizagem, formais ou informais, nos quais agem como canalizadores das diferenças nos sistemas e valores de grupos letrados (SIGNORINI, 2004).

Silva (2009) afirma que jovens e adultos que voltam a estudar apresentam uma característica em comum: sua sobrevivência no mundo do trabalho pela certificação, considerando que o fator certificação traduz o entendimento do processo de rejuvenescimento ou juvenilização da EJA. Observamos que Ribeiro (1999) já pontuava a 
habilidade de leitura diária por parte daqueles que buscam a inserção no mundo do trabalho, bem como a melhoria da qualidade de vida dos indivíduos na sociedade de cultura letrada.

Desse modo, ler constitui-se uma das competências mais relevantes a serem trabalhadas com o aluno e tem um significado que transcende a decodificação de letras e sílabas e/ou simples reprodução de informações latentes no texto, relegando, assim, a importância da dimensão da interação verbal, que deve permear a prática leitora. Assim, colocar em prática as orientações apresentadas nos Parâmetros Curriculares Nacionais (BRASIL, 1997), para viabilizar o processo de leitura de vários gêneros textuais, pode representar, para todos os envolvidos nesse processo, práticas de transposição de conteúdos e de vivências de metodologias diversificadas que considerem os sujeitos como atores/construtores sociais que interagem quando enunciam. Nesse sentido, o texto passa a ser considerado o próprio lugar da interação e os interlocutores passam a ser considerados sujeitos ativos.

Compreendemos, dessa forma, que o processo de leitura/compreensão não é uma simples apreensão. Como observa Soares (1998, p. 26), os educadores precisam reconhecer que

[...] um adulto pode ser analfabeto porque marginalizado social e economicamente, mas se vive em um meio em que a leitura e a escrita têm presença forte, se interessa em ouvir a leitura de jornais feita por um alfabetizado, se recebe cartas que os outros leem para ele, se dita 
cartas para que um alfabetizado a escreva. [...] se pede a alguém que lhe leia avisos ou indicações afixadas em algum lugar, esse analfabeto é, de certo modo, letrado, porque faz uso da escrita, envolve-se em práticas sociais da linguagem escrita.

Assim sendo, quando o aluno da EJA chega ou retorna à escola há de se considerar o repertório de conhecimento de mundo já adquirido através da linguagem no decorrer de suas vidas. Entretanto, precisamos ter em mente a possibilidade do aluno ainda não ter adquirido ou que esteja em processo de construção dos conhecimentos do sistema linguístico, dos conhecimentos da organização textual e dos conhecimentos de outros meios semióticos. Para tanto, cabe aos programas de formação de professores ressignificar a práxis educativa em torno do ensino da leitura, o que começa pela formação do professor. Implica também saber se este é um professor/leitor, no sentido de ser um incentivador, com condições favoráveis para despertar no aluno a vontade de também ler determinado texto.

Entretanto, ao lidar com uma demanda social de histórias distintas com práticas sociais de leitura na escola, cabe-nos compreender que o ingresso no mundo da leitura, como nos aponta Abreu (2003), muitas vezes é equivocado, pois atribui ao professor de português a incumbência plena do exercício da leitura, e elege o texto literário como objeto exclusivo da atividade de leitura. Comungamos com a ideia de Antunes (2009), para quem o trabalho com leitura não é atividade exclusiva do professor de português, cabendo, ao contrário, ao professor 
de qualquer disciplina, considerar a premissa de que ele é um leitor e, para sua atividade de ensino, faz uso de diferentes gêneros textuais.

Kleiman \& Moraes (1999) advertem que o ensino da leitura reflete as contradições e incoerências que vêm caracterizando o contexto pedagógico como um todo. E, consequentemente, a escola realiza atividades de "leitura" sem entendimento; interpreta-se sem se ter lido e realizam-se exercícios escolares sem nenhuma função na realidade sociocultural, o que dificulta a formação de leitores proficientes.

$\mathrm{Na}$ perspectiva de apreender a forma como se evidencia o processo de construção de leitura, é necessário compreender as suas diversas funções sociais, que vão desde a leitura de informação, passando pelo contato social, até a leitura para o entretenimento (ORLANDI, 1988). Logo, concordamos com Solé (1998), que o ensino deverá estar direcionado à formação de leitores que possam aprender a partir dos textos e interrogarem-se sobre a própria compreensão, capazes de estabelecer relações entre o que é lido e o que compõe o seu acervo pessoal, isto é, questionar seu conhecimento e mudá-lo, além de transferir o aprendido para outros contextos diferentes.

Foi dessa forma que buscamos dirigir nossa pesquisa tanto no campo dos estudos linguísticos quanto da Educação. Ao investigarmos a realidade de sala de aula, no que tange às práticas de leitura na EJA, buscamos dialogar com outras áreas do conhecimento das ciências sociais e humanas, para entender a relação da leitura na vida desses sujeitos investigados. Assim, fez-se necessário compreender como a negação de um direito à educação reflete na vida cotidiana desses sujeitos sociais. A escola, 
especificamente o professor, necessita ter clareza sobre essa realidade, de modo a procurar ações escolares destinadas à inserção social do aluno dessa modalidade de ensino.

Nesse momento, é oportuno esclarecermos que, por se tratar de uma pesquisa realizada numa instituição da rede pública municipal, buscou-se, em virtude dessa conjuntura, organizar as ações escolares em torno do ensino da leitura, tendo como base orientações curriculares desse município. Isto foi motivado pela preocupação de atender a questão introdutória que perfaz o percurso das políticas públicas de fomento à leitura, materializadas no planejamento escolar. Este, por sua vez, buscou, em parte, seguir às orientações curriculares da Secretaria de Educação de Campina Grande-PB, cumprindo as datas já previstas no calendário oficial.

Na nossa prática docente, percebemos que nem sempre a escola oportuniza ao aluno espaço e tempo para a formação de sujeitos leitores. Comungamos com a ideia de que a prática educativa evidenciada na escola, em relação ao ensino da leitura, muitas vezes, contradiz-se. Como sustenta Rodrigues (2012), a leitura de mundo é essencial para a compreensão do texto e da vida humana, considerando a atuação do homem nos diferentes setores na sociedade. No entanto, a experiência do aluno é ignorada na sala de aula e sua voz silenciada. Mas o contrário é o que nos motiva nessa pesquisa: faz-se necessário pensar os entraves que dificultam a compreensão da leitura na atualidade, de modo a contribuir para a formação de cidadãos que dialogam com os textos, construindo sua própria identidade. 
Diante disso, e em prol da sistematização das ações didáticas na sala de aula, optamos pela metodologia denominada de escuta sensível, sugerida por Barbier (2002), vinculando-a ao princípio da dialogicidade, defendido por Freire (1994). Nesse processo de escuta sensível, evidenciado no contexto escolar noturno, procuramos criar um espaço para o desenvolvimento da linguagem oral, cuja finalidade permitiu ao docente ouvir as vozes dos estudantes da EJA, conhecer suas histórias de vida, suas expectativas quanto à necessidade da leitura em sua realidade social. Esta ação de ouvir o alunado resultou na organização de um trabalho de intervenção pedagógica, com vistas a facilitar o acesso à leitura de diversos textos, tanto no interior da escola quanto fora dela, e numa perspectiva do letramento.

Outro aspecto teórico que buscamos para a nossa pesquisa foi a estreita relação entre o agir docente e a atividade de linguagem do aluno, que ecoa dos postulados do ISD. Pinto (2007), conforme o pensamento de Bronckart (1999), assume a concepção de que o objeto de estudo das ciências humanas e sociais abrange todas as ações que dizem respeito às condições de desenvolvimento e funcionamento das condutas humanas. Opondo-se a todas as formas de idealismo e de subjetivismo, que predominaram nas condutas e na linguagem humana, ele estabelece como base para o estudo do desenvolvimento e funcionamento dessas condutas a caracterização e a constituição sócio-histórica das mesmas. Essa ideia se fundamenta na concepção de que todo desenvolvimento humano se efetiva no "agir" humano, e não em elucubrações produzidas por uma atividade meramente cerebral, restritas a um espírito ou a uma alma. Para tanto, o ISD 
assume que o desenvolvimento humano se realiza através de duas vertentes complementares e indissociáveis: a do processo de socialização e a do processo de formação individual. Assim, em todo processo de desenvolvimento humano, a linguagem desempenha um papel decisivo, fundamental e insubstituível, no sentido de linguagem como "atividade" em sua perspectiva social e discursiva.

É importante esclarecer que as contribuições do ISD aludem ao desenvolvimento humano e social das atividades formativas, "cujas ações implicam transmissão de conhecimentos e valores éticos e comportamentais" (PINTO, 2007, p.116). Assim, na EJA, certamente, encontramos alunos que buscam a melhoria em suas vidas. Pensando na realidade social desses alunos, não podemos esquecer a contribuição de pesquisadores da área do ISD, no que concerne à perspectiva da linguagem destinada ao desenvolvimento do ser humano, de seu pensamento consciente, mediante a interação com os valores difundidos na sociedade.

Desse embate teórico, quanto à garantia de uma metodologia adequada, que viesse a contribuir para a aprendizagem da leitura por parte do aluno, destacamos também os PCN (BRASIL, 1997), cuja abordagem, numa perspectiva sócio-interacionista, sinaliza para o estudo da linguagem como forma de ação ou interação. Segundo o documento, cabe à escola viabilizar o acesso do aluno ao universo de textos que circulem socialmente, bem como ensinar a produzi-los e interpretá-los. 
Diante disso, para organizarmos os eventos de letramento na sala de aula em foco, buscamos suporte ainda em Rojo (2009a, p. 109), para quem:

Dois conceitos bakhtinianos podem auxiliar nossa reflexão: o conceito de esfera de atividade ou de circulação de discursos e o conceito de gêneros discursivos (Bakhtin 1992[195253/1979]. Na vida cotidiana, circulamos por diferentes esferas de atividades (doméstica e familiar, do trabalho, escolar, acadêmica, jornalística, publicitária, burocrática, religiosa, artística etc.), em diferentes posições sociais, como produtores ou receptores/consumidores de discurso, em gêneros variados, mídias diversas e em culturas também diferentes.

Sabemos que os sujeitos sociais da pesquisa, além da esfera escolar, têm acesso diariamente à esfera jornalística, como consumidores de notícias e com a programação da TV e da internet; como também são interlocutores da publicidade, como consumidores de produtos cosméticos (Avon, Natura etc.) e ainda de produtos de cunho religioso, entre outras atividades da esfera burocrática e do comércio. Além disso, fazem uso da revista como esfera de entretenimento, momento em que o aluno, na condição de leitor, busca obter informações de resumos de novelas, horóscopos, saúde entre outras situações. Como aponta Rojo (2009b, p.110), “as esfera de atividade e de circulação 
de discursos não são estanques e separadas, mas, ao contrário, interpenetram-se o tempo todo em nossa vida cotidiana".

Com o objetivo de evidenciar práticas de letramento escolar na sala de aula da EJA, a partir da leitura de revistas de circulação nacional, com ênfase para a sobrevivência dos alunos na cultura marcadamente letrada, propomos em nossa pesquisa repensar a prática docente da EJA, mediante ações didáticas que estimulassem o aluno leitor/trabalhador a conceber a leitura numa perspectiva de letramento que, acreditamos, vai além do processo de decodificação, contribuindo para a formação de um leitor proficiente e garantindo, assim, a aprendizagem ao longo da vida.

Para o desenvolvimento da pesquisa, utilizamo-nos de instrumentos e técnicas adequados ao objeto de estudo, por meio de observação participante, entrevistas gravadas e questionários, acrescidos do acompanhamento da professora-pesquisadora, através do uso do diário de bordo, de cujas anotações derivam a visualização sistemática de cada sequência de eventos relacionados à aprendizagem dos sujeitos participantes da pesquisa, conforme orienta Bortoni-Ricardo (2011).

$\mathrm{Na}$ investigação, foram abordadas questões relativas às práticas de leitura, nas quais destacamos nossas inquietações: Quais práticas de leitura são efetivadas no ambiente escolar? Como os sujeitos sociais da EJA aprendem a ler? Que gêneros textuais circulam na sala de aula que possibilitam para o aluno a aprendizagem da leitura? É possível inter-relacionar os textos veiculados na sociedade contemporânea capitalista à dinâmica da sala de 
aula? De que modo às práticas de letramento podem ser desenvolvidas na EJA?

Para as atividades de intervenção, buscou-se o procedimento sequência didática, a partir do conceito elaborado por Scheuwlly \& Dolz (2011, p. 82): “conjunto de atividades escolares organizadas, de maneira sistemática, em torno de um gênero textual oral ou escrito"; e Rojo (2008), no que tange à organização dos procedimentos didáticos do planejamento em torno dos gêneros textuais abordados na pesquisa.

Ao longo da pesquisa, a professora-pesquisadora não se viu apenas como usuária de conhecimento produzido por outros pesquisadores, mas se propôs a produzir conhecimentos sobre seus problemas profissionais, de forma a melhorar sua prática. O que distingue um professor-pesquisador dos demais profissionais é seu compromisso de refletir sobre a própria prática, buscando reforçar e desenvolver aspectos positivos e superar as próprias deficiências. Para isso, ele se mantém aberto às novas estratégias (BORTONI-RICARDO, 2011).

Nos item que se segue, observaremos que as ações pensadas e planejadas para essa pesquisa permitiram vivenciar que o processo de interação da professora-pesquisadora e atores escolares acontecesse pela escuta das vozes desses alunos, suas histórias de vida, destacando as dificuldades enfrentadas no cotidiano, em vista da inexistência das competências leitoras exigidas pela cultura letrada. Diante disso, justificamos que não pretendemos transformar tais ações docentes em práticas prontas e acabadas, mas permitir, a partir delas, o repensar de nossas ações profissionais em sala de aula, postas como o fazer profissional do professor-pesquisador da Educação 
Básica, que necessita de uma formação continuada para pensar/construir uma escola democrática que se preocupe com a qualidade do ensino no país.

\section{Microanálise da sala de aula}

Apresentamos a análise da prática escolar de uma sala de aula de I ciclo inicial e final, inserida no $1^{\circ}$ segmento do Programa Especial de Educação de Jovens e Adultos (PREEJA), na rede pública municipal de Campina Grande-PB, em torno da leitura mediada com o uso de revistas. A ação metodológica de intervenção nessa sala de aula teve a duração de 103 aulas. Foi um período de observações participativas, em que a professora-pesquisadora passou a entrevistar os alunos da EJA, indagando-os acerca de questões que anteriormente eram consideradas "familiares" pela docente.

A sala de aula, lócus da pesquisa, era constituída por 29 alunos regularmente matriculados, que se encontravam frequentando as aulas, salvo os casos daqueles estudantes que exerciam atividades laborais, com exigência de jornada de trabalho extra (vigilante pedreiro e cabeleireira).

No que concerne à faixa etária dos atores sociais envolvidos na pesquisa, oscilava entre 12 e 65 anos, distribuídos da seguinte forma: 17 do sexo feminino e 12 do sexo masculino; o que caracteriza, nitidamente, um descompasso entre idade e alunos que ainda não sabem ler, e, consequentemente, aponta para uma demanda escolar mais jovem na EJA, uma população cada dia mais jovem, já expressa por Brunel (2008). A pesquisa nos remete para o ressignificar do cotidiano escolar e as relações que se estabelecem entre os sujeitos que se encontram inseridos neste espaço. 
Em razão do descompasso existente entre os alunos com faixa etária distinta, em relação ao perfil da EJA, optamos por investigar quais atividades contribuíam para o aluno avançar (ou não) no processo de aquisição da prática de leitura. Buscamos o diálogo entre os sujeitos da pesquisa para, posteriormente, em outros eventos de letramento, sistematizados no decorrer da pesquisa, refletir sobre o grau de satisfação desses alunos, quanto às atividades realizadas em cada aula.

Diante do exposto, partimos para a coleta de dados, com uso da metodologia "roda de conversa", com o intuito de, através da conversação, possibilitar o intercurso verbal em que os participantes sociais da pesquisa possam se alternar e destacar as situações sociais, nas quais tiveram a necessidade do uso da leitura em sua vida diária. Observamos que os relatos desses alunos apontaram para as mais diversas necessidades pessoais e profissionais. Cada aluno pontuou cenas do dia a dia, em que foi prejudicado pela ausência da aprendizagem da leitura.

Priorizamos a escuta sensível ${ }^{3}$ para que, através dos relatos das histórias de vida desses alunos, buscássemos

3 A escuta sensível é o instrumento metodológico do pesquisador que se propõe a conhecer e transformar uma realidade opressiva. [...]. René Barbier é francês, pesquisador e Professor Emérito na Universidade de Paris VIII - Saint Denis, e produziu uma metodologia para dar conta da teoria que elaborou. Sua metodologia caracteriza-se por unir dimensões sociológicas e psicológicas e denomina-se 'Abordagem Transversal, a escuta sensível em ciências humanas'. Seu trabalho desenvolveu-se a partir da psicologia junguiana e das ideias do filósofo grego Castoriadis, para quem o mundo humano é o mundo do fazer. Incorporou também ideias de estudiosos orientais (CANCHERINI, 2010, p.3). 
metodologias adequadas para o desafio de ajudá-los a aprender a ler: ouvi-los para o compromisso de mudar a prática educativa. Pautados em Cancherini (2010), buscamos estabelecer o diálogo entre os participantes da pesquisa, de modo a pontuar os aspectos fundamentais que os conduziram a procurar a escola noturna, no que tange à apreensão da aquisição da leitura. Tal procedimento permitiu buscar compreender suas justificativas e iniciativas na busca da escolarização.

Os participantes da pesquisa, identificados por letras ${ }^{4}$, ao longo da investigação expuseram suas narrativas de vida, em torno dos desafios em conviver sem o domínio da leitura. Foram diferentes histórias; porém, optamos por destacar algumas, tendo em vista aquelas que mais se aproximaram do fenômeno estudado.

No início da realização da roda de conversa, o aluno da EJA sempre verbalizava determinada dificuldade nos diferentes contextos sociais, nos quais passou constrangimento devido à ausência do domínio do código escrito. Convém ressaltar que, para o sujeito social que estava aprendendo a ler, bem como melhorando sua leitura, tudo se traduziria em alegria. Ao contrário, verificamos, em alguns alunos, uma autoestima baixa, especificamente na aluna A, de 38 anos, que dizia ser incapaz de aprender a ler.

Porém, na medida em que a investigação avançava, percebíamos que o que antes julgávamos familiar em relação ao perfil dos sujeitos sociais em foco havia se modificado, pois nosso conhecimento tinha sido ressignificado. A

4 Atendendo aos princípios éticos da pesquisa, os sujeitos são identificados por letras: A, C, B, H, L, T, N, S, e P. 
professora-pesquisadora buscava sair da zona de conforto e partia para a problemática de sua investigação, apontando para a leitura com sentido, não só na perspectiva da decodificação, mas, sobretudo, conduzindo o aluno da EJA a se tornar um leitor crítico, nas mais variadas práticas de leitura, que poderiam advir tanto do espaço escolar quanto fora dos muros da escola.

Nessas inquietações, no que tange a não aprendizagem da leitura por parte dos alunos inseridos na sala de aula em foco, a professora-pesquisadora revelava a preocupação quanto à garantia de uma prática escolar adequada às expectativas dos sujeitos sociais da pesquisa. Essa pesquisadora observava, por um lado, a aluna A, que já frequentava a sala de aula desde 2010, com frequência normal, e que não havia aprendido a ler. Ela se restringia à execução de atividades de escrita na condição de "copista", ou seja, ela não lia o que estava escrito nas atividades propostas pela professora-pesquisadora, não entendia os enunciados. Por outro lado, o aluno L, de 18 anos, cobrava o ensino de letras e sílabas, por entender que ninguém aprendia a ler sem conhecer esses elementos. Ele não concordava com a ideia de ler textos de gêneros discursivos nas aulas em que a pesquisa se efetivava.

Nossos encaminhamentos didático-metodológicos, durante a investigação, vêm sinalizar a opção em torno de um gênero textual e foram motivados pelo relato da aluna $\mathrm{T}$, de 33 anos. Essa aluna, já conhecedora da problemática da aluna A, no que tange a não aprendizagem da leitura, sugeriu que ela fizesse como seu exemplo fora da escola: que passasse a ler revistas de horóscopo, pois ela "aprenderia rapidinho". 
A fala da aluna $\mathrm{T}$ nos faz pensar a nossa prática docente, e a própria formação de professores no país, pois questiona o ensino da leitura, inclusive nos indicando a necessidade da leitura de gêneros textuais veiculados por múltiplas linguagens, em que é de fundamental importância à habilidade de ler para a inserção cultural e social, para a construção de conhecimentos na sociedade contemporânea. A recomendação de como se "aprende rapidinho" da aluna $\mathrm{T}$, de 33 anos, reflete sua percepção da relevância da leitura numa perspectiva de letramento social. Como pensam Mollica \& Leal (2012, p.13), "Alguns autores afirmam que os letramentos dependem de momentos e de situações diferentes de alunos, do contexto sócio-histórico e regional das pessoas, bem como de suas necessidades mais imediatas". Podemos observar que a fala da aluna T legitima tal assertiva citada por Mollica \& Leal (2012), haja vista seu deslocamento de uma vida "tranquila", no interior da Paraíba, à vida "agitada" do Rio de Janeiro, onde se faz necessário o uso de uma educação linguística, tendo em vista "os letramentos multissemióticos exigidos na vida cidadã contemporânea" (ROJO, 2009b, p.107).

A professora-pesquisadora iniciava a aula falando sobre as dificuldades vivenciadas por um sujeito que não sabe ler num mundo letrado e logo se deparava com as falas de cada aluno da EJA acerca da necessidade de estudar, das suas inquietações com as letras, entre outros aspectos pertinentes a cada vida social. Através do uso do diário de pesquisa, ela pôde fazer os registros dos acontecimentos observados no dia a dia da sala de aula, no sentido de não omitir dados. Consequentemente, houve um entendimento por parte dos sujeitos participantes em colaborar com a investigação, ora via registro oral, 
mediado sob a forma de entrevista gravada; ora pela conversa em sala de aula, dentre outras estratégias.

Cumpre ressaltar que o trabalho com a utilização de revistas difere de práticas escolares em que, em sua maioria, encontram-se destinadas a recortes e colagem, bem como caça-palavras. Em nosso trabalho de pesquisa, o foco foi na leitura de eventos de letramento que proporcionam atividades de leitura interativa, sócio-discursivamente, legitimadas pelos usos sociais dos alunos envolvidos em práticas de linguagem. Considerando o nível de aprendizagem dos atores escolares, procuramos trabalhar com as capas de revistas, por considerá-las gêneros multimodais, além de ser igualmente uma unidade comunicativa, assim como os demais gêneros que compõem a revista.

Diante disso, evidenciamos a aluna $\mathrm{T}$, de 33 anos, para quem as experiências empíricas na cidade do Rio de Janeiro resultaram na decisão em querer aprender a ler, principalmente pela necessidade de ler as diferentes linguagens (sinalização do trânsito, cartazes, endereços etc.). Observamos que a saída dessa aluna do município de Boqueirão-PB, aos 13 anos, sem saber ler, com a meta de trabalhar para ajudar seus familiares, exemplifica os inúmeros casos de alunos da EJA que foram impedidos de estudar por uma questão de desigualdade social, e cabe à escola não ignorar tal fato sócio-histórico-cultural. Evidenciamos que procurar um endereço, para a aluna $\mathrm{T}$, era um "sacrifício", bem como o deslocamento da sua residência ao trabalho, no referido município. Notadamente, por não saber ler, restava-lhe o serviço doméstico, atividade laboral na qual também precisava fazer uso social da leitura, como ler os recados da patroa, dar remédios às crianças, entre outras atividades. 
A aluna T relatou também que, após uma sucessão de dificuldades enfrentadas no cotidiano da cidade grande, não procurou mais a escola, mas sim a ajuda de uma prima que, mediante seus apelos no dia a dia, reservou um momento para ensiná-la a ler. Tal procedimento sugerido por essa prima teve início através da leitura de revistas de horóscopo. A partir daí, a aluna T passou a comprar a revista indicada pela sua prima, cuja leitura diária tinha a intervenção dessa parenta que, "com muita paciência", conseguiu a ação de decifrar o código linguístico, levando a aluna $\mathrm{T}$ a finalmente ler efetivamente.

Frente a esse relato, a professora-pesquisadora considerou como sendo favorável o evento de letramento apresentado pela aluna $\mathrm{T}$ e passou a comprar revistas e levá-las à sala de aula para favorecer a prática de leitura relatada pela aluna da EJA. Nesse evento de letramento em torno das práticas de leitura com o uso do horóscopo, considerando o formato da revista, surgiu a problemática do tamanho da letra, pois, naquela sala de aula, era observada a presença de alunos com problemas de visão. Esses alunos não conseguiam ler o sumário, bem como as informações de cada signo, tendo em vista as letras serem pequenas para a decodificação/compreensão textual. Diante da dificuldade revelada pelos sujeitos agentes da pesquisa, no momento da leitura, optamos por mudar o tipo de revista, considerando o fato de que o aluno não lia devido a uma restrição pessoal.

Em nossa prática de ensino/pesquisa, deparamo-nos também com o aluno L, que reproduzia em sua fala uma tradição de ensino já cristalizada no contexto da EJA, exigia, por parte da professora-pesquisadora, um tipo de ensino que contemplasse o estudo de letras, sílabas e 
frases. Segundo a opinião desse aluno, ninguém aprendia a ler usando textos, mas com a utilização do método sintético. Cobrava inclusive o uso de exercícios tradicionais, a exemplo do ditado. Como pontua Rojo (ROJO, 2010, p. 36):

[...] a ideologia sobre alfabetização registra uma história de iniciar com as vogais isoladas, para depois se chegar às sílabas e palavras (Justamente, métodos sintéticos como fônico) e essas palavras não se prestavam bem ao trabalho, pois apresentavam, em sua maioria, como é o caso de português em geral, sílabas complexas (CVC, CCV) e não simples (CV). Eram, pois, 'palavrinhas muito difíceis'. (Grifos da autora)

Entendemos que o aluno L traz consigo a história de alfabetização da escola tradicional. Então, buscamos incluir na nossa prática escolar exercícios que viessem a atender ao pedido do aluno, também como forma de viabilizar a continuidade da nossa investigação. Desse modo, reservamos um espaço cotidiano para a realização de ações escolares com o método sintético, partindo das contribuições de Lemle (2005) para o ensino de ortografia, cujas orientações metodológicas nos subsidiaram no trabalho com cruzadinhas, caça-palavras etc., aproveitando-se dos gêneros que compõe a revista.

Ao refletirmos acerca da nossa inquietação em investigar o questionamento em torno das práticas de leitura que são efetivamente materializadas no planejamento escolar, 
vimos, portanto, que essa realidade, no que tange ao acervo bibliográfico e à prática do planejamento escolar, favorece uma articulação entre teoria e prática, tanto nas questões relacionadas ao ensino e à precariedade dos serviços prestados na escola, quanto ao pensamento ideológico de formar pessoas "competentes", com capacidades e habilidades para agir no mundo cercado de desigualdade social. Trata-se de alunos que buscam a escola, no caso da EJA, movidos, muitas vezes, por questões outras que não o simples desejo ou necessidade de aprender, sendo frequentemente a pergunta feita pelo aluno ao professor, no início da aula, se terá merenda escolar naquele dia. A questão é pensar não só em como ensinar, mas, sobretudo, mediar nossas inquietudes por estudos e áreas do conhecimento como a Sociologia, a Psicologia, a Geografia, buscando repensar nossas práticas escolares e ajudar os sujeitos escolares a enxergarem possibilidades de mudança num quadro de complexidade.

As ações em torno da leitura foram reformuladas no desenvolvimento de nossa pesquisa, haja vista a presença da aluna A, de 38 anos que, apesar de toda essa ação educativa de incentivo à leitura, "não aprendeu a ler na escola". Esse entrave derivou a reformulação metodológica de nosso estudo e do plano de trabalho, tendo em vista a ação escolar em torno do ensino da língua materna para essa modalidade de ensino, levando-se em consideração que em uma turma heterogênea poderá ocorrer casos especiais como o que destacamos. Diante disso, decidimos trabalhar a leitura por meio de revistas.

A professora-pesquisadora buscou, no trabalho com revistas, analisar os efeitos de sentido na construção da competência leitora dos alunos participantes da 
investigação, partindo do discurso legitimado da prática de sala de aula em foco. Assim, as práticas de leitura se deram com o uso de revista na sala de aula, partindo de revistas de circulação nacional, Guia Astral, Ana Maria e Viva, Máxima, no que concerne às suas reportagens e anúncios, focados em produtos de moda, beleza e saúde feminina, entre outros. Encontramos jovens e adultos que, baseados em suas histórias empíricas, revelaram seus pontos de vista acerca dos temas tratados nas revistas supracitadas, ora concordando ora discordando, conforme sua formação cultural/ideológica.

A professora-pesquisadora seguiu com seu trabalho, levando exemplares de revistas à sala de aula, conforme o interesse pessoal dos participantes da pesquisa (religiosidade, revistas/catálogos de vendas de produtos de cosméticos: Natura, Avon etc.), buscando disponibilizar o acesso à diversidade de gêneros textuais ao aluno, além de modelos de arquitetura de texto. Como defende Bakhtin (1992), o gênero se configura em três dimensões: construção composicional, conteúdo temático e estilo verbal; todas determinadas conforme situação de produção dos enunciados. De modo que, com o acesso a tais revistas e a determinados discursos, o aluno, na condição de leitor, posicionava-se com relação aos signos ideológicas presentes nos textos estudados em sala de aula, buscando atribuir um sentido para cada texto e fazendo sua relação com o cotidiano social dos alunos da EJA.

Destacamos que a leitura realizada cotidianamente, mediada por revistas, incentivou o gosto pela leitura de tais gêneros textuais, como a partir da própria capa, sumário, anúncio publicitário, entre outros, considerando que as revistas selecionadas para a leitura em sala de aula 
tratavam de temas da atualidade, e que tais assuntos eram de interesse dos participantes da pesquisa. Outro aspecto a ressaltar é que a aquisição dessas revistas foi feita pela professora-pesquisadora, com recursos próprios, haja vista a escola não dispor de um acervo e recursos financeiros que pudessem ser utilizados para essa prática de letramento.

Na prática de leitura com uso de revista foi utilizada uma variedade de tipos de revistas de circulação nacional, particularmente de fácil acesso aos participantes da pesquisa. Nessas práticas de leitura, trabalhamos com diversas revistas, entretanto para a visualização do trabalho desenvolvido na sala de aula, apresentamos a Revista Máxima, Ed. Abril, ano 3, no 4, edição 28, de setembro de 2012, em resposta à necessidade de facilitar o diálogo entre os participantes da pesquisa em torno dos conteúdos enfatizados pela revista citada. Nesse momento, a professora-pesquisadora procurou agrupar os alunos conforme o nível de aprendizagem, de modo que, em cada grupo, os alunos pudessem ler com colaboração mútua, considerando inclusive o nível de amizade existente entre cada um: o aluno considerado como tímido passava a ler com a parceria do colega de sala de aula.

Para a sistematização desta atividade de leitura, a professora-pesquisadora distribuiu para cada participante da pesquisa a cópia da capa da revista Máxima mencionada anteriormente, acrescida do sumário. Cabe registrar que a leitura do sumário representou outro momento de aprendizagem, no qual o aluno observou suas respectivas características textuais e função. Nessa atividade de leitura, partimos para enfatizar a leitura dos números, solicitando que o aluno da EJA procurasse, por indicação da 
professora-pesquisadora, localizar determinado texto jornalístico, atentando para a orientação impressa no sumário. Constatamos que, em tal atividade, o aluno, uma vez conhecedor dos números naturais, não revelou dificuldade na procura dos gêneros textuais apontados naquela aula. Assim, pudemos observar que a leitura de um gênero implica a experiência de outras leituras, do conhecimento de outros gêneros textuais e, em atividades planejadas em momentos posteriores, esses alunos vieram a demonstrar habilidades de compreensão no manuseio de gêneros diversos, em termos de buscar a matéria jornalística, seguindo o critério de organização de paginação.

Figura 1 - Revista Máxima: (a) Capa e; (b) Sumário; e (c) Reportagem

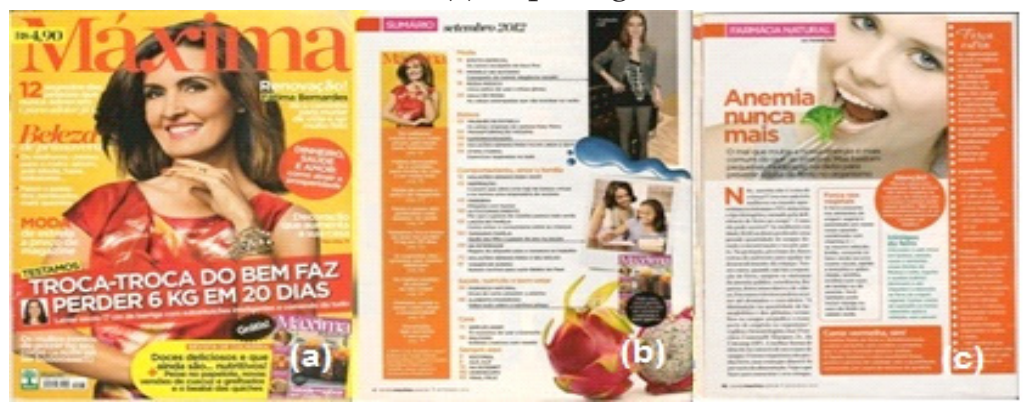

Fonte: Acervo pessoal da professora-pesquisadora

No decorrer da atividade, observamos uma situação vivenciada por outro aluno, a quem chamamos $\mathrm{H}$, que foi bastante relevante. Dessa vez, o aluno mostrava interesse em ler a Revista Máxima. Ele sinalizou dúvidas quando lia a matéria intitulada "Anemia nunca mais", na qual consta a expressão "As mulheres em idade fértil". Ele atenta para o significado do sentido do texto. Ao ser indagado pela 
professora-pesquisadora acerca do sentido da expressão "idade fértil", o aluno $\mathrm{H}$ respondeu que se tratava "de uma mulher magra, sei não, é?", demonstrando insegurança em sua resposta.

Diante do ocorrido, foi lançada uma proposta de investigação para a turma, buscando analisar o nível de compreensão por parte das alunas da EJA que eram genitoras. Logo, foram verificadas as dificuldades dessas alunas em responder o que elas entendiam por idade fértil. Apenas um aluno aproximou a resposta, fazendo alusão ao ciclo menstrual. Isto despertou o interesse do grupo em fazer uma breve exposição sobre a temática "período fértil".

Do debate suscitado em torno da expressão "idade fértil", a partir de sugestão das alunas participantes da pesquisa, o momento de leituras com as revistas em sala de aula seria denominado de "Nossas descobertas". Nessa perspectiva, a leitura das revistas era desenvolvida no decorrer das aulas, atentando para as informações expressas nas capas. Tais atividades fomentavam momentos de pesquisa, principalmente quando se tratava de uma palavra ou expressão desconhecida pelos alunos. Só existia o avanço das discussões orais e escritas em torno dos textos lidos depois de verificado o entendimento por parte da turma.

Após práticas de leitura diversas, mediadas por revistas, a professora-pesquisadora concluiu a aula, destacando alguns avanços daquele encontro, como a leitura de alguns implícitos encontrados nos textos, bem como alguns momentos de interlocução do leitor com o texto e demais leitores presentes naquele espaço de letramento. 
Figura 2 - Leitura de textos diversos das revistas

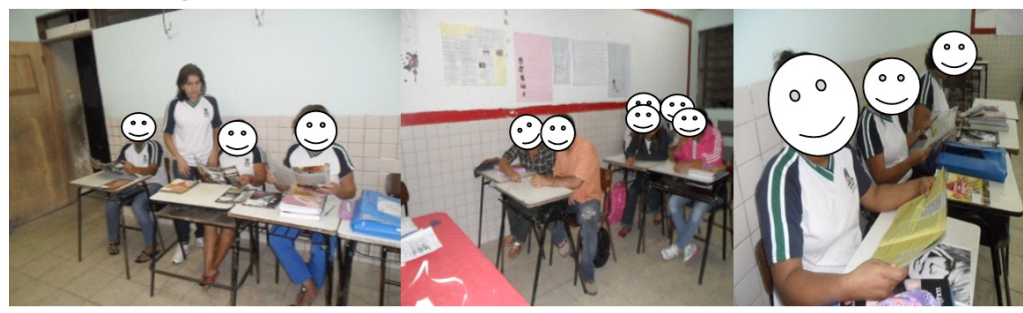

Fonte: Acervo pessoal da professora-pesquisadora

$\mathrm{Na}$ aula seguinte, a professora-pesquisadora organizou um evento de letramento extraclasse. A leitura de revista seria num lugar onde encontrávamos a revista enquanto produto que se comercializa, ou seja, numa das três bancas de revistas localizadas na Praça da Bandeira, no centro da cidade de Campina Grande-PB. Após as visitas, optamos pela Banca do Orlando. Lá, pudemos observar o entusiasmo dos alunos em manusear as revistas e focar a atenção pela lembrança principalmente daquelas revistas utilizadas na sala de aula.

Figura 3 - Evento de letramento em banca de revistas

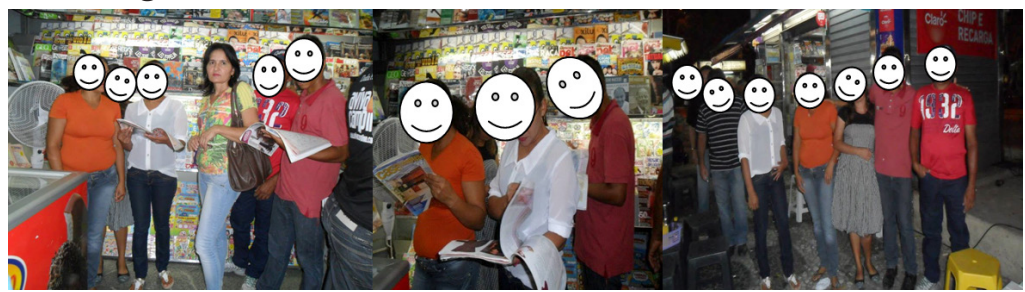

Fonte: Acervo pessoal da professora-pesquisadora

Convém destacar que o acesso ao local onde havia uma variedade de tipos de revistas, com pessoas desconhecidas ao contexto de sala de aula, não resultou num 
comportamento de timidez por parte do aluno da EJA. Pelo contrário, os alunos leitores se posicionaram com familiaridade em meio ao aparato de revistas expostas nas prateleiras, com diferentes temáticas. Examinavam a capa, liam os assuntos e, caso gostassem da revista, logo atentavam para o preço, rapidamente decodificado, e posteriormente selecionavam as que interessavam para comprá-las.

A observação da interação desses sujeitos sociais na banca de revistas possibilitou um avanço na pesquisa. Pudemos registrar a compra de revistas do tipo atualidades, novelas, orações, moda, culinária, entre outras, por parte do aluno da EJA. Apesar de não termos enfocado a literatura de cordel, constatamos marcas de nossa identidade cultural através da ação da aluna S, de 65 anos. Essa aluna, ao chegar à banca de revistas, olhou as revistas, porém deu atenção especial ao cordel. Logo comprou um cordel para dar ao seu marido, com a justificativa de que ele apreciava esse tipo de leitura.

Um fato relevante foi o de uma aluna que se fez presente nesse evento de letramento na banca de revistas, mesmo não tendo participado diretamente da pesquisa, por estar matriculada em outra turma, pertencente ao II ciclo final - séries iniciais $\left(4^{\circ}\right.$ e $5^{\circ}$ ano). Ela demonstrou desconhecimento quanto à leitura da capa de revista. No momento em que queria comprar uma determinada revista e não localizava o preço, logo buscava informação com o dono da banca. Imediatamente, os participantes da pesquisa mostraram para essa aluna o preço da revista.

Diante disto, observamos que nem sempre em sala de aula o docente planeja atividades de leitura para explorar tais conhecimentos, elementares para uma pessoa que 
atua numa sociedade letrada. Vimos, portanto, que tal gênero textual, embora considerado popular, traz informações que dificultam a vida de uma pessoa que não sabe ler, ainda mais quando sabemos que tais textos carregam uma gama representativa de implícitos contidos em enunciados verbais e não verbais importantes para a compreensão e, portanto, capazes de validar os gêneros textuais como prática social. Assim, pudemos pontuar aspectos positivos de nossa pesquisa, haja vista que não basta decodificar o texto, mas compreender o sentido que ele veicula, valida, atualiza.

Destacamos que, dentre as práticas de leitura promovidas pela professora-pesquisadora, foi deveras produtivo levar os participantes da pesquisa ao centro da cidade de Campina Grande-PB, objetivando proporcionar a leitura fora da escola, no lugar em que comumente encontramos revistas à venda. E ainda a participação da confraternização entre os participantes da pesquisa, numa pizzaria, após a realização de uma pesquisa de títulos e preços de futuras aquisições de revistas para as leituras em aulas subsequentes. Objetivava-se a vivência da leitura da esfera jornalística em uma banca de revistas, acrescida pelo momento de confraternização entre os sujeitos sociais, juntamente com a professora-pesquisadora na pizzaria. Contextos sociais nos quais esses alunos da EJA tiveram acesso ao uso do gênero textual no seu contexto social específico, além de terem a oportunidade de usá-los, demonstrando as habilidades e competências leitoras exigidas para tais práticas sociais. 
Figura 4 - Leitura de cardápio

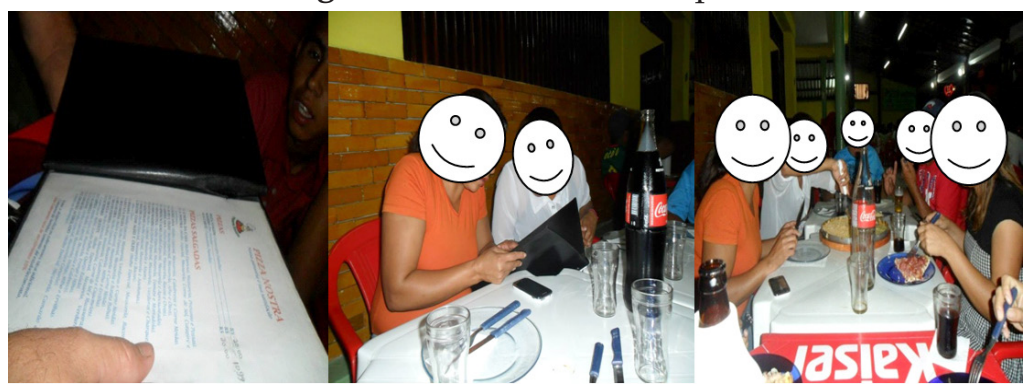

Fonte: Acervo pessoal da professora-pesquisadora

Vale ressaltar que a escolha da pizzaria decorreu de uma pesquisa de preço realizada pela aluna $B$, de 36 anos, a "procurar uma pizza de qualidade com preço acessível", no centro de Campina Grande-PB, atentando para as condições econômicas dos sujeitos sociais participantes da pesquisa. Na pizzaria, o aluno teve acesso ao gênero textual cardápio, e nele fez uso social da leitura. Analisou os tipos de pizzas disponíveis naquele estabelecimento comercial e avaliou se preço era compatível com a realidade econômica dos colegas de sala.

Dos diversos relatos apresentados em nosso estudo, cabe destacar o da aluna que exercia a função de gari, justamente no lugar onde se localizavam as três bancas de revistas visitadas em nossa pesquisa-ação. Essa aluna, de 42 anos, já deixava claro nos encontros de leitura em sala de aula a sua não identificação como leitora de revistas em âmbito social e que quando questionada em dias anteriores se não tinha vontade de entrar na banca para folhear tais revistas, verbalizou que passava o dia todo ali, mas "limpando, isto é, trabalhando" e não vendo à hora de "voltar para casa e arrumar as coisas para vim para escola 
estudar". Essa aluna não se via leitora fora do ambiente escolar, estava centrada na leitura na escola. Porém, com o desenvolvimento das rodas de conversa, realizadas na sala de aula, atreladas aos diversos relatos das novas descobertas feitas pelo "o encanto da leitura", nos mais diversos contextos sociais, inclusive na banca de revistas (onde os alunos da EJA estiveram envolvidos com a leitura efetiva, socioculturalmente evidenciada pelo ato de ler); ela ora profissional ora aluna expressou que até então não tinha observado que poderia também ter acesso aquele ambiente de leitura: "via revistas, às vezes, jogadas no chão, as quais faziam a coleta de lixo", e pouco refletia, observava, "eram lixo, não revistas". E assim seguia, vendo possíveis leituras como lixo por não ter a leitura como função social.

Como nos recomendam Molica \& Leal (2012, p.3), “os programas de alfabetização de jovens e adultos devem estar fortemente conscientes de suas responsabilidades quanto à utilização oportuna de estratégias eficazes de inserção dos alunos na vida letrada". Com efeito, o acesso à leitura das revistas utilizadas em nossa prática de ensino e pesquisa na formação do professor permitiu ao aluno da EJA o desenvolvimento de um olhar crítico, de modo a contribuir para a formação de um leitor reflexivo. Iniciativa que reflete nossos estudos com base em pesquisadores que defendem a valorização de práticas de leitura como prática social, dentro e fora da escola. 


\section{Considerações finais}

Pensar a prática de leitura na EJA, num processo de letramento escolar, implica conhecer os saberes dos sujeitos sociais inseridos na pesquisa. Da atuação de um professor reflexivo derivam conhecimentos práticos e teóricos, com vistas à elaboração de uma proposta de trabalho de intervenção vinculada ao uso da leitura numa perspectiva do letramento. Desse modo, pensar a proposta de trabalho docente para o lócus da pesquisa fomentou a reflexão acerca da trajetória histórica da educação brasileira e suas implicações no processo de letramento escolar de um número acentuado de jovens e adultos que são excluídos da escola. Essa exclusão social gera a não participação do sujeito aluno em práticas e eventos de letramento, por virtude desse sujeito social não saber ler e, consequentemente, não dispor das habilidades e competências leitoras exigidas pela sociedade contemporânea.

Entre as inúmeras funções atribuídas à escola na sociedade atual, destacamos que a formação de leitores competentes e proficientes não é uma tarefa fácil. Exige do aluno, desde a infância, o acesso à cultura do mundo letrado, que pode vir tanto de ambientes escolares como da própria história de vida do aluno, com o contato com histórias contadas por outras pessoas. Percebemos ainda que não basta equipar a escola com bibliotecas, com um acervo variado de obras literárias clássicas e aparatos tecnológicos modernos, sem dispor de recursos humanos que valorizam a leitura como um bem cultural e significativo, que a concebam como uma necessidade vital para a convivência no mundo contemporâneo com as novas tecnologias do mundo globalizado. 
A leitura ocupa lugar de destaque por meio da variedade de gêneros textuais, assim como são instigados vários elementos de construção do texto. Nesse sentido, a prática pedagógica em sala de aula evidencia a satisfação dos alunos no atendimento às suas necessidades leitoras, tanto na vida escolar quanto na vida cotidiana. Reconhecemos, também, nesse momento de nossa vida acadêmica e profissional, que a formação continuada possibilita ao profissional em exercício na Educação Básica momentos de reflexão acerca de sua prática, considerando que a formação inicial não contempla conhecimentos práticos quando se tratam de realidades de sala de aula, como é o caso específico da EJA, na qual os materiais didáticos produzidos para esse público, quando existem, se restringem ao livro didático.

Diante desse desafio profissional, que é a dificuldade da aprendizagem da leitura na EJA, cabe ao professor rever suas metodologias, voltando-se à especificidade do aluno. Não há receitas, mas, sobretudo, possibilidades de espaços de leituras numa perspectiva de eventos de letramento, cuja interação com os gêneros textuais impulsiona os estudantes da EJA a participarem dos eventos que podem ser situados em contextos específicos, como em nosso caso, em que a leitura se efetivou em uma banca de revistas, inclusive permitindo que a leitura adquirisse sentido a partir da experiência do aluno da EJA, posto em cena social na condição de leitor crítico.

Os resultados da pesquisa atingem aspectos positivos em relação à aprendizagem da leitura dos sujeitos sociais apontados neste trabalho, considerando que as práticas de leitura com uso de revistas tratam de assuntos de interesse desses sujeitos, como também destacando o aspecto 
fundamental para o crescimento profissional, conforme ocorreu com as alunas que liam receitas culinárias, com o intuito de diversificar o cardápio em suas atividades laborais. Um procedimento de leitura executado mediante revistas com assuntos da atualidade, demonstrou o interesse, bem como a participação ativa nas discussões geradas em torno das temáticas abordadas pelas aulas de leitura.

Vimos, portanto, em nossa pesquisa, que repensar a realidade social de negação do direito à educação, a uma demanda social de história de fracasso escolar, de desigualdade social, passa inclusive pela formação docente em relação à mudança das práticas escolares, ao ensino da língua materna, à possibilidade de dialogar com os atores sociais e buscar, através de práticas de alfabetização, numa perspectiva do letramento, contribuir para a participação cidadã e a inserção social dos sujeitos que acorrem à escola da EJA. Ressaltamos o caso da aluna A, de 38 anos, que motivou nossa ação docente com o estudo da leitura em sala de aula, com foco no uso de revistas. Ela se envolveu com a prática, encontrando o prazer pela/na leitura, motivando todos para a aquisição de mais revistas, de mais leituras, a cada encontro. Uma prática que adquiriu proporções positivas, e momentos encorajadores, como quando essa aluna relata o quanto é emocionante poder decifrar o código escrito, chorando, ao mesmo tempo em que sorria, por se revelar, descobri-se, leitora.

Diante disso, amadurecemos para o entendimento de que refletir a prática de leitura na perspectiva de formação de leitores críticos perpassa pela formação inicial e principalmente continuada, cujo encaminhamento das ações teórico-metodológicas nos possibilita aproximar a teoria da prática com mais amadurecimento profissional. 


\section{Referências}

ABREU, M. Os números da cultura. In: RIBEIRO, V. M. (Org.). Letramento no Brasil: Reflexões a partir do INAF 2001. São Paulo: Global, 2003, p.33-45.

ANTUNES, I. Língua, texto e ensino: outra escola possível. São Paulo: Parábola, 2009. (Estratégias de Ensino; 10)

BAKHTIN. M. Estética da criação verbal. São Paulo: Martins Fontes, 1992.

BARBIER, R. A pesquisa-ação. Tradução de Lucie Didio. Brasília: Plano, 2002. (Série Pesquisa em Educação, v.3)

BORTONI-RICARDO, S. M.; O professor pesquisador: introdução à pesquisa qualitativa. São Paulo: Parábola, 2011.

BRASIL. Parâmetros Curriculares Nacionais: $1^{\text {a }}$ a $4^{\text {a }}$ Séries do Ensino Fundamental. Secretaria de Educação Fundamental. Brasília: MEC: SEF, 1997.

BRONCKART, J. P. Atividade de linguagem, textos e discurso: por um interacionismo sóciodiscursivo. São Paulo: EDUC, 1999.

BRUNEL, C. Jovens cada vez mais Jovens na Educação de Jovens e Adultos. 2. ed. Porto Alegre: Mediação, 2008.

CANCHERINI, A. A escuta sensível como possibilidade metodológica. In: IV Seminário Internacional de Pesquisa e Estudos Qualitativos. Pesquisa qualitativa: rigor em 
questão. Fundamentos - Métodos e desdobramentos. Rio Claro: SE\&PQ, 2010, p.1-7.

FREIRE, P. Educação como Prática da Liberdade. Rio de Janeiro: Paz e Terra, 1994.

GERALDI, J. W. O texto na sala de aula. São Paulo: Ática, 5,ed. 2011.

. Portos de Passagem. São Paulo: Martins Fontes, 2013.

KLEIMAN, A. B. Oficina de leitura: teoria e prática. 10. ed. Campinas, SP: Pontes, 2001.

KLEIMAN, A. B.; MORAES, S. E. Leitura e interdisciplinaridade: tecendo redes nos projetos da escola. Campinas, SP: Mercado de Letras, 1999. (Coleção Ideias sobre a linguagem)

LEMLE, M. Guia teórico do alfabetizador. 16. ed. São Paulo: Ática, 2005. (Série Princípios).

MOLLICA, M. C.; LEAL, M. Letramento em EJA. São Paulo: Parábola. 2012.

PINTO, R. O interacionismo sociodiscursivo, a inserção social, a construção da cidadania e a formação de crenças e valores do agir individual. In: GUIMARÃES, A. M. de M.; MACHADO, A. R.; COUTINHO, A. (Orgs.). O interacionismo sociodiscursivo: Questões epistemológicas e metodológicas. Campinas, SP: Mercado de Letras, 2007, p.111-119. (Coleção Ideias sobre Linguagem) 
ORLANDI, E. P. Discurso e leitura. Campinas, SP: Cortez, 1998.

RIBEIRO, V. M. (Org.). Alfabetismo e atitudes: pesquisa com jovens e adultos. Campinas, SP: Papirus, 1999.

ROJO, R. Alfabetização e Letramento: perspectivas linguísticas. Campinas, SP: Mercado de Letras, 2009a.

. Letramentos múltiplos, escola e inclusão social. São Paulo: Parábola, 2009b.

- Alfabetização e letramentos múltiplos: como alfabetizar letrando? In: RANGEL, E. O.; ROJO, R. H. R. (Orgs.) Língua Portuguesa no Ensino Fundamental de 9 anos e materiais didáticos. Brasília, DF: MEC. 2010, p. 15-36. (Coleção Explorando o Ensino)

RODRIGUES, L. P. Atitude responsiva na interação verbal: a relevância do contexto para a significação/compreensão leitora. In: XAVIER, Manassés Morais. (Org.). Linguística Aplicada em Foco: Práticas e Propostas de Ensino de Língua Materna na Formação Continuada de Professores. 1. ed. Campina Grande, PB: Realize Editora, 2012, v. 1, p. 637-649.

SCHNEUWLY, B.; DOLZ, J. Gêneros Orais e Escritos na Escola. 3. ed. Campinas, SP: Mercado de Letras, 2011,p. 25-78.

SIGNORINI, I. Letramento e (in)flexibilidade comunicativa. In: Os significados do letramento: uma nova perspectiva sobre a prática social da escrita. Campinas, SP: 
Mercado de Letras, 2004, p. 161-199. (Coleção Letramento, Educação e Sociedade)

SOARES, M. Letramento: um tema em três gêneros. Belo Horizonte: Autêntica, 1998.

SOLÉ, I. Estratégias de Leitura. 6. ed. Porto Alegre: Artmed, 1998.

SILVA, Analise de Jesus da. A formação inicial dos professores de adolescentes: os adolescentes existem na EJA? Paidéia, Belo Horizonte, Ano 6, n. 7, p. 39-59, jul./dez. 2009.

ZILBERMAN, R. Como e por que ler a literatura infantil brasileira. Rio de Janeiro: Objetiva, 2005. 



\title{
MEMÓRIAS DOS IDOSOS QUILOMBOLAS DO MATÃO/PB: Narrativas para o desenvolvimento de práticas de ensino
}

\author{
Marta Oliveira Barros ${ }^{1}$ \\ João Batista Gonçalves Bueno ${ }^{2}$
}

\section{Introdução}

Este artigo discute trechos da pesquisa que resultou na dissertação de mestrado de Marta Oliveira Barros, do Programa de Formação de Professores da Universidade

1 Graduada em Licenciatura Plena em Geografia e Pedagogia, pela Universidade Estadual da Paraíba, especialista em Educação de Jovens e Adultos, com Ênfase em Economia Solidária, pela Universidade Federal de Campina Grande, e Mestra pelo Programa de Pós-Graduação em Formação de Professores (PPGFP/UEPB). Atualmente é professora nos municípios de Lagoa Seca e Queimadas no estado da Paraíba, além de colaboradora da especialização em Educação de Jovens e Adultos, com Ênfase em Economia Solidária (UFCG). barros.marta21@gmail.com

2 Graduadoem História eDoutoremEducação, Professor Adjunto do Departamento de História do Centro de Humanidades da Universidade Estadual da Paraíba (UEPB). Pertence ao quadro permanente do Programa de Pós-graduação em Formação de Professores da UEPB e ao Programa de Pós-graduação em História da Universidade Federal da Paraíba (UFPB). joaobgbueno@hotmail.com 
Estadual da Paraíba e que foi defendida em 2016. Essa pesquisa tinha como objetivo investigar e problematizar como as memórias de idosos da comunidade quilombola do Matão- $\mathrm{PB}^{3}$ poderiam ser utilizadas nas escolas básicas, em especial na E. M. E. F. José Rufino dos Santos, para o desenvolvimento de atividades didáticas de História e Geografia. Marta partiu da necessidade dos moradores mais velhos da comunidade, que ansiavam que a escola participasse de uma campanha para a produção de referências identitárias para os jovens estudantes. Os quilombolas precisam permanecer morando em suas terras, caso contrário eles podem perder o direito a ela. Por isso, os residentes do povoado percebiam que a falta de identidade dos jovens com sua raça e com as tradições quilombolas provocava nos jovens o desejo de migrar para outros lugares ou centros urbanos mais desenvolvidos. Marta, procurando contribuir para a resolução desse problema, iniciou sua pesquisa realizando entrevistas com idosos do local, registrando as memórias que faziam parte da História desse lugar.

Após ter colhido muitos depoimentos, Marta propôs encontros com os professores da escola fundamental do vilarejo. E, este foi o momento em que ela apresentou as narrativas dos idosos, sugerindo que as docentes elaborassem formas de uso e atividades didáticas partindo dessas

3 Segundo BARROS (2016), "a denominação Matão se refere a uma área bem mais ampla que a comunidade de remanescentes quilombolas, a qual se estende da fazenda Matão, que se localiza próxima ao município de Ingá- PB. Este espaço é conhecido pelos habitantes da comunidade como 'Matão de Dona Rosita'. Já o espaço que ocupa a comunidade Quilombola é conhecido na região como 'Matão do Negros'. (2016, p. 38-39). 
memórias. As professoras da escola fundamental acharam mais conveniente construírem sequências de temas étnico - raciais locais, os quais poderiam ser encaixados nos currículos oficiais da escola. Essas sequências de conteúdos produzidas pelas professoras seriam estudadas durante o semestre letivo e serviriam para despertar discussões sobre o lugar onde os alunos residiam. A ideia era a de que as memórias dos idosos do local passasse a fazer parte dos conteúdos de estudo da escola. Assim, por meio delas as professoras poderiam trabalhar questões que se referiam ao sentimento de identidade local, tanto da raça negra como do espaço territorial quilombola. Estas atividades resultaram, também, na ideia de criação de significados para o estudo das disciplinas de História e de Geografia do lugar, valorizando, portanto, as histórias, as culturas locais e os espaços geográficos desta comunidade quilombola.

Considerando esse contexto, a pesquisadora partiu dos seguintes questionamentos: como os professores dos ensinos fundamental poderiam utilizar os depoimentos de idosos para a produção do conhecimento escolar? Como esses docentes utilizariam esses tipos de fontes históricas nas salas de aula? Como as teorias pedagógicas poderiam contribuir para a elaboração de atividades didáticas com relatos memoriais em sala de aula? Quais as necessidades destes professores para aperfeiçoar suas aulas quanto às temáticas: comunidade, memória, trabalho e identidade? Como as universidades poderiam contribuir para a efetivação de práticas escolares que dão ênfase a produção do conhecimento escolar relacionados as disciplinas da História e da Geografia local e regional? 
No transcorrer do desenvolvimento de sua investigação Marta percebeu que as práticas de rememorar histórias do passado estavam vinculadas às experiências de vida dos idosos do Matão. E ao constatar isso, passou a utilizar como referenciais teóricos as ideias de Walter Benjamin (1994) que acreditava que o ato de narrar e rememorar atuava no processo de formação histórica das sociedades.

Buscou, então, construir problematizações sobre as formas de pensar as seleções de conteúdos curriculares das escolas básicas. E, notou que a sequência de assuntos que eram estudados nas escolas quilombolas se fundamentavam nos livros didáticos, os quais apresentavam concepções eurocêntricas. Assim, os conteúdos disciplinares que eram trabalhados pelas professoras concentravam-se em abordagens generalizadas e, por isso, distantes da realidade vivida pelos alunos quilombolas. Isso reduzia a possibilidade de elas desenvolverem discussões em sala de aula sobre as questões raciais presentes na comunidade. Além disso, limitavam as formas de percepção dos estudantes sobre suas condições de vida e sobre o mundo que eles vivem.

Como já nos referimos, as professoras desta escola quilombola, utilizavam apenas os currículos oficiais expostos nos livros didáticos, e por isso, não conseguiam abordar os temas locais. Ao perceber isso, Marta procurou discutir as concepções dos currículos, destacando a importância da introdução de conteúdos que valorizassem saberes locais ou regionais. Fez isso, pois acreditava que por meio deles era possível criar processos de ensino que considerassem perspectivas interculturais e que partissem das concepções de descolonização do saber e poder. Reconheceu, então, que as memórias dos idosos da comunidade do 
Matão tratavam de distintos temas, os quais possibilitavam a criação de atividades didáticas que poderiam positivar as experiências, as sensibilidades e as tradições dos negros e das mulheres quilombolas do Matão.

Percebeu também que essa pesquisa poderia contribuir para as escolas quilombolas de diferentes locais do Brasil. Pois, essas múltiplas comunidades, semelhantemente, enfrentaram processos violentos de apagamentos culturais, os quais dificultam suas lutas para a construção das suas identidades enquanto grupos sociais.

Dessa maneira, acreditamos que é muito importante desenvolvermos estudos que valorizem a diversidade social brasileira, porque, por meio deles são possíveis a criação de perspectivas que possam trazer a luz saberes que, até a poucas décadas atrás, eram considerados primitivos, inválidos e fadados à extinção. Entendemos que esta pesquisa auxiliou para a revelação de que os saberes subalternos resultam da reelaboração de diferentes significações e tradições, bem como, possibilitam uma compreensão do mundo de forma muito mais ampla.

Todas as análises de depoimentos produzidas neste artigo partem de leituras dos registros orais dos idosos da comunidade do Matão-PB, e suas interpretações foram feitas à contrapelo (BENJAMIN, 2012), e tem confirmado a ideia de que os processos de exploração econômica sofridos na Paraíba alteraram as vidas dos sujeitos, provocaram mudanças dos seus costumes e modificaram suas práticas de trabalho. Utilizamos também como aportes teóricos para o desenvolvimento dessa pesquisa as concepções dos seguintes autores: E.P.Thompson; S. Hall; E.Dussel e A.Quijano. 


\section{Refletindo sobre os currículos escolares}

Quando pensamos currículos multiculturais para o ensino de História e Geografia nos defrontamos com diferentes problemas que revelam os embates e os conflitos que se estabeleceram entre as culturas brancas, indígenas e negras, ou seja, as chamadas culturas dominantes na relação com as subalternas. Por isso, dentre as muitas possibilidades de adentrarmos nesta discussão, proponho inicialmente as seguintes indagações: como, a partir dos conceitos de descolonização do saber e do poder, podemos enfrentar os processos de organizações de conteúdos curriculares que estabelecem hierarquizações e apagamentos culturais e de identidades das comunidades indígenas e negras? Quais as possibilidades de realizaremos construções das Histórias regionais e locais, de forma que essas contribuam para a criação de visões afirmativas em relação a diversidade cultural e étnico-racial? E, como estabelecer os diálogos entre as histórias locais e regionais com as gerais que tratam da nação como um todo?

Neste texto não pretendemos esgotar todas as possibilidades de respostas que essas questões suscitam, pois, compreendemos que estes temas são complexos e podem ser abordados de diferentes perspectivas. Esperamos, no entanto, oportunizar a criação de visões que positivem experiências, sensibilidades e tradições dos grupos sociais representados por negros e índios do estado da Paraíba, que historicamente foram desvalorizados e submetidos a lugares sociais subalternos. Nossos estudos tem revelado que os saberes subalternos locais do estado da Paraíba, bem como as formas como se estruturam as relações de poderes locais resultaram da reelaboração de 
diferentes significações e tradições, e além disso, possibilitaram uma compreensão do mundo que se distancia das práticas racionais e homogeneizadoras da modernidade capitalista.

Sabemos que, até os dias de hoje, na segunda década do século XXI, os currículos do ensino de História e Geografia das escolas básicas brasileiras têm privilegiado as construções historiográficas de cunho eurocêntricas, e isso não é diferente no estado da Paraíba. Por isso, permanecem ainda hoje os tipos de abordagem que privilegiam as relações dicotômicas, as quais hierarquizam como dominantes as culturas de etnia branca sobre as culturas subalternas indígenas e negras. Como consequência a organização dos conteúdos escolares mantem a forma tradicional que apresenta as populações negras e indígenas como minorias primitivas e não-civilizadas, ou então, como populações vulneráveis e injustiçadas. Sendo assim, esta parcela da população requer do estado que sejam adotadas políticas afirmativas que buscam reduzir a desigualdade e a injustiça.

No Brasil este tipo de política foi iniciado após as promulgações da Lei $n^{\circ} 10.639 / 03$ e da lei $n^{\circ} 11.645 / 2008$, que estabeleceu que os currículos de ensino da História e de outras disciplinas das escolas básicas passassem a contemplar as temáticas relativas ao estudo das Culturas Afrobrasileiras, Africanas e indígenas. Também foi a partir dessas leis que o estado lançou as Diretrizes Curriculares Nacionais para a Educação das Relações Étnico-Raciais. Estes textos legais foram produzidos pelo estado e propuseram que os professores das escolas básicas desenvolvessem ações educativas positivas que valorizassem os saberes, as experiências e as tradições das comunidades 
originárias e negras. Esses documentos tiveram claramente o objetivo de valorizar ações afirmativas étnico-raciais, compreendendo que o modelo de educação intercultural pode ser produzido por relações horizontais entre as diferentes culturas. Ou seja, visões interculturais não se produzem por meio de superposições ou hierarquizações de uma cultura dominante sobre as culturas subordinadas, e, portanto, estas últimas não são o resultado das assimilações dos valores, das práticas e dos comportamentos da cultura dominante. Assim, o problema da educação étnico-racial não é uma questão exclusiva das populações originárias e negras, mas se estende a todos os setores da sociedade.

Outra questão que é importante quando discutimos os currículos das escolas básicas se refere a como os conteúdos étnico-raciais são apresentados nos livros didáticos. Os livros didáticos ainda apresentam os negros somente como escravos até o século XIX e os povos originários como seres primitivos, ou então, como sujeitos que são desprovidos de saberes e por isso foram dominados pelos brancos no momento da colonização portuguesa. Desprezam, portanto, toda a historicidade desses povos.

Por força dessas leis, citadas acima, no Brasil os currículos oficiais e os livros didáticos foram obrigados a considerar as diferenças étnico-raciais existentes no processo de formação populacional. Nesse sentido, acreditamos que a educação formal das escolas quilombolas podem ter um papel significativo para auxiliar os estudantes a fazerem releituras da história e cultura das populações negras que vivem no Brasil. Sendo a escola o espaço educacional onde as práticas culturais e costumes da etnia negra e indígenas podem ser valorizados e positivados. 
Foi no desenrolar desta pesquisa que percebemos que as práticas do esquecimento e/ou da inferiorização da história e da cultura dos sujeitos quilombolas do Matão$\mathrm{PB}$, são comuns e isto têm fortalecido atos de preconceito e de racismo. E, constatamos que essas questões nunca aparecem formalmente na educação básica, pois as professoras como não pertencem a comunidade, por falta de conhecimento dificilmente trabalhavam em sala de aula com aspectos da história e da cultura dessa comunidade.

\section{Os caminhos da pesquisa}

Ao propormos essa investigação oportunizamos que os estudantes da comunidade quilombola de Matão pudessem criar ressignificações sobre suas identidades como negros, valorizando os seus saberes e suas tradições. Foi por meio das rememorações dos idosos que residiam no mesmo local onde os estudantes moravam que trabalhamos os conceitos de suas identidades. Esses estudos foram baseados nas concepções teóricas os estudos Hall (2014), que entende que este conceito está sempre em movimento e sua construção vai se dando com o passar do tempo.

Destacamos que os idosos quilombolas demonstraram muito prazer ao narrar suas lembranças, e isso nos fez compreender como eram importantes os seus saberes e suas experiências vividas para a formação da identidade cultural da comunidade de Matão. Acreditamos nisto, pois alguns dos depoimentos que registramos expressavam as formas de resistência à opressão cultural que foram impostos a esses negros no passado. Sendo possível reconhecermos que essas formas de tratamento entre 
raças são correspondentes aos preconceitos que os negros ainda são submetidos nos dias atuais.

Para a realização deste estudo partimos da metodologia de pesquisa da história oral (Delgado,2006; Marcuschi 2013), propondo as três etapas de pesquisa como forma de aprimorar as fontes: a colheita de dados, a transcrição e finalmente a análise e interpretação das entrevistas. No ano de 2015 realizamos diversas entrevistas semiestruturadas, as quais foram gravadas e em seguida transcritas. E, a partir daí, passamos a discutir as formas possíveis de suas interpretações. Somamos um total de seis horas e trinta minutos de gravações, porém neste artigo nos limitaremos a citar apenas alguns trechos mais significativos das falas dos idosos. Neste texto tivemos como intuito a preservação das identidades dos depoentes, e por isso, optamos por nomear cada idoso por um nome de um orixá africano. Fizemos isso para estabelecermos relações com as divindades do candomblé, pois, praticamente essa religião de matriz africana desapareceu nesta comunidade. No caso deste artigo utilizamos os seguintes nomes: Iansã, Ogum, Oxum, Oxalá e Xangô.

Pudemos, partindo das memórias dos idosos, dar destaque a diferentes saberes dos negros quilombolas desta comunidade. Para fazermos isso iniciamos o trabalho com os professores e com os alunos da escola, apresentando-lhes o seguinte trecho do depoimento da senhora Oxum:

Ela pegava os meninus, ela era parteira. Ainda ela pegou, o que...uns 4 ou 5 mininu meu. Eu tive em casa mermu porque num dava tempo... atrai de arrumar uma pessoa que 
tivesse o carro pra vim, pra vim buscar num dava tempo. Tinha in casa mermu e ela fazia o parto nomalmente. É aquela minha irmã que mora im frente ao colégio e que é merendeira. (entrevista realizada com a senhora Oxum, setembro de 2015, Matão/PB); (BARROS, 2016.p.50).

Apoiados neste depoimento foi possível trabalharmos que até o final do século XX existiam mulheres nesta comunidade, as parteiras que auxiliavam no nascimento das crianças do Matão. Esse trabalho de saúde coletiva não é mais praticado neste povoado, pois os partos hoje em dia são realizados em maternidades nas cidades vizinhas. Por isso, muitos dos estudantes e as professoras da escola da comunidade de Matão desconheciam a existência dessas mulheres e isto fazia com que eles não reconhecessem que existiam diferentes saberes no lugar onde eles residiam ou lecionam.

Essas parteiras, ao exercerem essa função, necessitavam possuir diferentes conhecimentos sobre os processos de gestação, do parto e do pós-parto. Destacamos que essas mulheres, na maioria das vezes, se utilizavam dos saberes da experiência, relacionados a aplicação de métodos da medicina popular, os quais fundamentava-se em saberes ancestrais de uso de ervas, de rezas e outras tradições religiosas.

Foi baseado no depoimento da senhora Oxum, que pudemos compreender que esse trabalho tinha muita importância na comunidade e por isso, era muito valorizado no passado. Acentuamos para as professoras que 
não faziam muitos anos que essas práticas tinham acabado nesta comunidade, pois o depoimento da idosa era relativo às décadas de 1950 até 1980. No povoado de Matão, entre esses anos, não haviam programas estatais de assistência médica, dificultando que casos de urgência pudessem ter algum atendimento em hospitais das cidades vizinhas. Somado a isso, apontamos que existiam dificuldades de locomoção dos cidadãos que compunham essa comunidade, pois a pobreza das pessoas excluía a possibilidade de elas possuírem meios de transporte motorizados. E, por isso, essas parteiras exerciam um papel fundamental para a saúde local, sendo as responsáveis pelo bem-estar das parturientes e das crianças que nasciam neste local.

Além disso, sabemos que as profissões da área de saúde são muito valorizadas nos dias de hoje e assim passamos a questionar junto as professoras: $\mathrm{E}$ as parteiras do Matão? Será que suas experiências e saberes não tinham correspondências com as atividades dos médicos?

Entendemos que estes saberes e experiências faziam parte da história de vida das mulheres, dos homens e das crianças do Matão, e essa memória da senhora Oxum poderia estimular a curiosidade dos alunos e contribuir para valorizar aspectos da cultura desse lugar. Em vista disso, concordamos com Paulo Freire (2014) quando ele assevera que:

Como professor devo saber que sem a curiosidade que me move, que me inquieta, que me insere na busca, não aprendo nem ensino. Exercer a minha curiosidade de forma correta é um direito que tenho como gente e a 
que corresponde o dever de lutar por ele, o direito à curiosidade (FREIRE, 2014, p.83); (apud. BARROS, 2016, p.51).

Nesse sentido, entendemos que quando o professor lança mão das memórias de idosos, oportuniza que essas rememorações sejam apropriadas como conhecimentos, despertado nos jovens estudantes questionamentos que contribuam para a construção de identidades do grupo social as quais elas pertencem. Por conseguinte, ao utilizarmos esse tipo de fonte documental é possível desenvolvermos processos de aprendizagem prenhes de significados que podem auxiliar os sujeitos desse povoado quilombola a superar as barreiras que foram impostas historicamente.

Segundo Charlot (2000) existem três dimensões que fazem parte do processo de apropriação do saber e da aprendizagem, ou seja, deve-se desenvolver atividades de mobilização, de execução e de fazer o estudante sentir-se participante do processo de escolarização. Desta forma, entende-se que o estudante precisa de motivação e estimulo para querer aprender os conteúdos escolares. E as histórias narradas pelos idosos podem servir para isso.

Paulo Freire (2005) em suas pesquisas sobre métodos de ensino destacou que o processo de investigação temática ocorre por meio da construção de significados para os sujeitos que estão aprendendo, e por isso, esse recurso não pode ser visto de maneira simplificada como um ato mecânico. Ele se dá pelo encadeamento de séries de atividades de buscar o conhecimento, de investigar problemas e de construção de hipóteses. 


\section{Memórias de idosos quilombolas: possibilidades para o ensino de História e da Geografia.}

É certo entendermos que o idoso, quando expressa suas lembranças, faz uma determinada releitura do seu passado. Os velhos têm ao criarem suas narrativas memoriais têm a possibilidade de refletirem sobre suas experiências de vida, sobre suas visões sobre os fatos ocorridos com eles no passado e, dessa forma, reinventar suas identidades. Por essa razão, as memórias dos idosos quilombolas possibilitam nas pessoas que tem acesso a elas a reelaboração de novas versões sobre suas próprias vidas.

Bosi (1994) afirma que, na maioria das vezes, lembrar não é reviver as experiências do passado, mas refaze-las, reconstruí-las, repensa-las com imagens e ideias de hoje. Por esse motivo, entendemos que as narrativas memoriais expressam reconstruções de vivências do passado, como podemos observar na fala do idoso Ogum:

Tinha a Fazenda Riacho Verde... tinha tinha... a de Mané Borge, ele tinha só uma fazenda só, mai tinha muita terra, sabe? Chegava quase até Itabaiana... tinha Major João Celém... Naquele tempo... esse povo era major, era coroné... era tudo... E a gente trabalhou nas terras desse povo tudim... e outra, a gente era OBRIGADO a trabalhar... Nesse tempo, agricultura tava bem, chuvia... dava bem, os pai de famia trabalhava com a família toda, né? Em casa de ter dez, doze trabalhava tudo junto, butava um 
roçado grande como si di... lucrava bem... aqui, essas terras dava muito algudão, só que era pior do que hoje, ERA SUJEITO, sujeito a vender a eles... a vender a eles...avei eles comprava pelo menor preço e PAGAVA quando queria... todo final de semana, o pai de famia ia lá, ele dava um pedacim de dinheiro e avei passa o ano todo pa... pa... pagar. Por isso que esse povo não fizeram futuro de nada da agricultura, mode isso. (Entrevista concedida pelo Sr. Ogum à pesquisadora em junho de 2015, em Matão-PB); (BARROS, 2016, p. 69$)^{4}$.

Nesse cenário, podemos analisar que embora Ogum mantenha a forma de tratamento aos fazendeiros como "coroné" e "major", em seu testemunho, ele demonstra a revolta pela exploração do trabalho dos sujeitos de sua comunidade. Quando ele diz "por isso que esse povo não fizeram futuro de nada da agricultura, mode isso", faz uma releitura da situação de opressão a que os negros eram submetidos pelos coronéis da região. Nesse caso, podemos utilizar essas lembranças para criarmos releituras críticas das maneiras com que os quilombolas eram reprimidos pelos fazendeiros.

Vemos, portanto, que as memórias dos idosos quilombolas podem oportunizar que os sujeitos expressem

4 Entrevista concedida pelo Sr. Ogum à pesquisadora em junho de 2015, em Matão-PB. 
suas angústias e, principalmente, questionar a maneira pela qual as pessoas que viveram nesta comunidade eram excluídas e exploradas como força de trabalho.

De acordo com outro testemunho, o da idosa Iansã, os negros do Matão eram considerados diferentes dos outros habitantes que viviam nas cidades próximas à comunidade. Segundo suas declarações, quanto ela ia fazer suas compras na cidade, percebia como as pessoas ficavam olhando para ela, e isto a incomodava. "Óia, chegou a nega do Matão, vigi...". A partir desta fala, percebemos como os remanescentes de quilombos do Matão eram discriminados. Sofriam racismo e preconceito pelo fato de serem negros e morarem na comunidade quilombola.

Ao apresentarmos para as professoras essas de narrativas, elas puderam elaborar questões que teriam como objetivo lançar discussões sobre o presente dos alunos, percebendo que essas práticas preconceituosas racistas permanecem até os dias de hoje. Como ressalta Halbwachs:

Diríamos que cada memória individual é um ponto de vista sobre a memória coletiva, que este ponto de vista muda segundo o lugar que ali ocupo e que esse mesmo lugar muda segundo as relações que mantenho com outros ambientes (HALBWACHS,2006, p. 69).

Outro aspecto de uso da memória que utilizamos foi ressaltar que elas podem revelar formas de resistência à exploração do trabalho. A memória de resistência negra 
que mais aparece nos textos na historiografia brasileira é a de Zumbi dos Palmares. Entretanto, muitas outras formas de resistência existiram ao longo da história. Ao apresentarmos o depoimento abaixo conseguimos trabalhar com as professoras essas questões. No depoimento do idoso Xangô, ele nos revela que existiam momentos de humilhação, repressão e medo para os negros quilombolas. Mas que ao mesmo tempo, existia o sentimento de revolta e de reconhecimento de que eles sofriam repressões por pessoas que se julgavam superiores:

Ói, moça, eu tava inspirando, fiquei com raiva e medo dele butar aquela vara... eu vi muita vei ele butar nas venta dos nego, vi muita vei. Pensando cumigo: "quando ele butar, eu pego e puxo". Eu, naquele tempo, nego novo, ligero. Naquele tempo, eu era manero. Mai aquilo ali tinha gente arredor dele, os capanga dele pa gente num fazer nada. Era bruto dimai: “DE QUEM É PALU? DE QUEM? DE QUEM É PALU? ESSE ALGUDÃO?". "É de um rapai do Matão, homi trabalhador". "OTACILU É BRABO DO MATÃO, PALU? É, PALU? É O BRABO DE LÁ, É, PALU?".

Este depoimento é importante para revelar que os negros não se submetiam facilmente as opressões dos fazendeiros brancos, e por isso, pode contribuir para a 
valorização da raça e a construção do sentimento de identidade. Pollak, nos indica isso quando entende que:

Se podemos dizer que, em todos os níveis, a memória é um fenômeno construído social e individualmente, quando se trata da memória herdada, podemos também dizer que há uma ligação fenomenológica muito estreita entre a memória e o sentimento de identidade. Aqui o sentimento de identidade está sendo tomado no seu sentido mais superficial, mas que nos basta no momento, que é o sentido da imagem de si, para si e para os outros. Isto é, a imagem que uma pessoa adquire ao longo da vida referente a ela própria, a imagem que ela constrói e apresenta aos outros e a si própria, para acreditar na sua própria representação, mas também para ser percebida da maneira como quer ser percebida pelos outros (POLLAK, 1992, p. 05).

Assim, ao utilizarmos as memórias dos idosos quilombolas podemos positivar os processos de resistência racial e identitária, possibilitando a criação de processos de ressignificação cultural e histórica. Pollak, ainda afirma que:

Embora na maioria das vezes esteja ligada a fenômenos de dominação, a clivagem entre memória oficial e dominante e memórias subterrâneas, 
assim como a significação do silêncio sobre o passado, não remete forçosamente à oposição entre Estado dominador e sociedade civil. Encontramos com mais frequência esse problema nas relações entre grupos minoritários e sociedade englobante (POLLAK, 1989, p. 05).

Dentro desta perspectiva, o depoimento de Ogum pode ser utilizado para contextualizarmos essa visão:

Se antes a pessoa passou fome e hoje tá de barriga cheia, a pessoa deve lembrar... que passou fome antigamente, entendeu? Num é... quer dizer...se a gente for lembrar só do presente, a gente tem que lembrar do passado tombém. A gente somo adulto, devemo lembrar do tempo de criança... se fazia arte, se não fazia... eu lembro dos meus dez, doze ano... lembro de coisa ruim e de coisa boa tombém... avei isqueço, né?

Para Ogum, a memória é importante, pois é a partir dela que os quilombolas têm oportunidade de refletir sobre sua história. Quando o entrevistado diz: "Se antes a pessoa passou fome e hoje tá de barriga cheia, a pessoa deve lembrar... que passou fome antigamente", sua fala remete à leitura do passado como necessário para a compreensão do processo de formação da comunidade. Isto porque as formas de luta e sobrevivência dos remanescestes devem 
ser explicitadas para as gerações que não tiveram oportunidade de vivenciá-las.

Ora, se hoje os remanescentes de quilombolas têm seus direitos garantidos mediante a Constituição brasileira, deve-se lembrar que houve todo o um processo de lutas, conquistas e derrotas.

\section{Ponderações sobre as comunidades quilombolas}

No contexto nacional, as comunidades quilombolas paraibanas se destacaram por sua força de resistência ao escravismo. De acordo com Moura (1987), na Paraíba, o quilombo era a forma preferida de rebeldia no período colonial e durante o império. Os escravos fugiam para as matas, e a fuga era um processo comum para se conseguir a liberdade. Contudo, o estado português e depois o império não aceitavam as suas existências, determinando constantemente as suas destruições. A classe dominante paraibana sempre tentou combater a expansão dos quilombos na província valorizando modos de repressão que se expressavam por atos de crueldade e castigos corporais aos fugitivos. Como afirma Moura (1987), todo negro fugido que era encontrado passava a ser ferrado como um animal com a letra F na testa e era cortada uma orelha caso resistisse. Porém, os negros sempre resistiram ao processo de escravidão e mesmo existindo tais medidas, elas não tinham força para impedir a fuga dos escravos para os quilombos. Nesse sentido, são compreensíveis as estratégias dos quilombolas de lutar contra o sistema opressor. Apesar de muitos terem morrido lutando por liberdade, 
Na Paraíba, em 1865, os escravos se rebelam ao verem as torturas a que um dos escravos presos fora submetido. Os demais presos atiram-se sobre a guarda, estabelecendo-se sério conflito, tendo morrido na luta os escravos Ildefonso, Félix, Tomás, e o guarda nacional Manuel dos Prazeres. Além desses mortos, houve vários feridos (MOURA, 1987, p. 21).

A partir desse breve relato histórico sobre a luta dos negros por sobrevivência, é possível compreender que na Paraíba, como em outros estados brasileiros eram cenários de brutalidade em relação aos negros. Contudo, os quilombos paraibanos conseguiram se expandir e se firmaram em territórios que na época de suas formações eram distantes das fazendas dos coronéis. No entanto, na atualidade, todos eles fazem limites com grandes fazendas.

Atualmente, os quilombos têm parceria com organizações sociais em prol das comunidades negras. Segundo Elio Flores (2014), os movimentos sociais na Paraíba impulsionaram o surgimento das seguintes entidades: Associação de Apoio às Comunidades Negras, Organização das Mulheres Negras da Paraíba e Associação das Mulheres Negras de Caiana dos Crioulos. Desta forma, essas entidades têm contribuído para que as comunidades de remanescentes quilombolas da Paraíba tenham melhores condições para reivindicar seus direitos, bem como formarem associações de moradores dentro de suas comunidades. De acordo com um professor da comunidade do Matão-PB, “Temos hoje na comunidade a maioria das 
casas de alvenaria porque lutamos através da associação da comunidade" (informação verbal) ${ }^{5}$.

Assim, as organizações sociais, principalmente as associações comunitárias, são muito significativas para melhorar as condições de vida das comunidades quilombolas do Estado. Elio Flores (2014) entende que essas entidades comunitárias têm contribuído tanto para a divulgação de suas existências como para melhorar as informações que formam os bancos de dados de blogs e de site na Internet6. Portanto, esses grupos quilombolas da Paraíba vêm se destacando por conseguirem seus reconhecimentos legais e por lutarem pelos seus direitos de posse das terras.

De acordo com o Art. $2^{\circ}$ do Decreto-Lei n. 4887/2003 em seu parágrafo primeiro diz que: “A caracterização dos remanescentes das comunidades dos quilombos será atestada mediante autodefinição da própria comunidade" (BRASIL, 2003b, art. 2).

Como afirmam (FLORES, p. 18, 2014), "com a comunidade conhecendo seus direitos, organizada, fortalecendo e sendo fortalecida pelo Movimento Quilombola e seus aliados, é possível avançar na garantia da regularização dos territórios".

Portanto, através do Movimento Quilombola as comunidades remanescentes da Paraíba passaram a exigir o direito material da titulação de suas terras. Segundo Elio Flores (2014), os anos de 2005 a 2007 foram muito importantes para a constituição material dos direitos quilombolas

5 Entrevista concedida pelo Sr. Oxum à pesquisadora em 2015, em Matão-PB.

$6<$ http/quilombosdaparaiba.bloggspot.com.br>. Nesse endereço, o usuário poderá obter informações sobre as comunidades remanescentes quilombolas da Paraíba. 
na Paraíba. Foi nesse período que muitas comunidades conseguiram a certificação da Fundação Cultural Palmares como comunidade remanescente de quilombos, como, por exemplo, Engenho do Bonfim, Matão, Pedra d'Água, Santa Teresinha, Caiana dos Crioulos, entre outras.

Segundo a Fundação Cultural Palmares, até dezembro de 2015, a Paraíba possuía 37 comunidades reconhecidas de povos remanescentes de Quilombo, localizadas desde o litoral até o sertão Paraibano.

Nesse panorama, a Associação de Apoio aos Assentamentos e Comunidades Afrodescendentes (AACADE) foi muito importante no processo de certificação das comunidades paraibanas. Como afirma Elio Flores:

Após fazer a localização das comunidades, a AACADE se disponibiliza em visitá-las enquanto comunidades rurais negras. Nestas eles se empenham em realizar reuniões com o intuito de conscientizá-los de especificidades e de situações desaforidas. Esse trabalho muitas vezes culmina em um período de envio à Fundação Palmares (FCP), de autorreconhecimento enquanto comunidade rural quilombola. (FLORES, p. 65, 2014). Assim, a AACADE é uma das entidades sociais mais significativas no processo de auto reconhecimento quilombola na Paraíba, não apenas para obter a posse de terras, mas sobretudo para auxiliar na organização social das comunidades. 
De acordo com o I Seminário de Mulheres Negras realizado em 2011, em João Pessoa, a Paraíba ofertava escolas dentro de comunidades remanescentes de quilombo. No entanto, estas escolas funcionavam de maneira precária.

O Plano Estadual da Educação Básica da Paraíba vigente para os anos 2015-2024 relata que $72,1 \%$ destas escolas estavam localizadas em comunidades remanescentes quilombolas, mas ainda 31,4 estão localizadas fora das comunidades. Estes dados são preocupantes, uma vez que estas instituições de ensino são do primeiro ciclo da educação básica. Isto significa que as crianças para continuar seus estudos têm de se deslocar para outros lugares, em outras comunidades mais distantes. Além disso, na maioria das vezes não são evidenciadas no currículo destas instituições de ensino as questões de sua identidade, da história e da cultura negras.

Como afirma o Plano Estadual de Educação (20152024), "na maioria das escolas de comunidades quilombolas, é adotado o sistema multisseriado e, por consequência, a qualidade de ensino está abaixo da média nacional" (PARAÍBA, 2015, p. 128).

\section{A elaboração das sequências de conteúdos}

A partir reuniões realizadas com as professoras e o gestor da E. M. E. F. José Rufino dos Santos, foi estudada a possibilidade de auxilia-las no processo de desenvolvimento de atividades educativas que valorizassem a história e cultura do Matão. Logo, estabelecemos que era necessário ofertarmos uma oficina, intitulada "MEMÓRIAS DE IDOSOS QUILOMBOLAS: PRÁTICAS PEDAGÓGICAS NUMA PERSPECTIVA DE 
RESSIGNIFICAÇÃO IDENTITÁRIA", cujo objetivo principal foi auxiliar os professores da comunidade a ressignificar a identidade dos estudantes a partir das memórias dos idosos da comunidade do Matão-PB.

Desta oficina resultou a sequência de conteúdos que se encontra abaixo. Ela foi elaborada pelos professores no diálogo com a pesquisadora Marta e seu orientador Prof. Dr. João B. G. Bueno. Partindo das memórias dos idosos do Matão as professoras das escolas básicas propuseram as seguintes intervenções curriculares:

QUADRO 02: Proposta dos conteúdos a serem inseridos no currículo da escola.

Conteúdos

(a) Religião de matriz africana; $1^{\circ}$ bimestre

(b) Território e territorialidade; $1^{\circ}$ bimestre

(c) Organização social comunitária; $2^{\circ}$ bimestre

(d) Costumes e tradições quilombolas; $3^{\circ}$ bimestre

\section{Referências}

Memórias das rezadeiras;

Trabalhar questões de religiosidade local e as religiões de matriz africana;

As traições e as ervas utilizadas para a cura e os benzimentos.

Memória das relações de poder; luta pela terra e sobrevivência dos quilombolas;

Como se dava o trabalho nas fazendas;

As relações entre as pessoas da comunidade e os fazendeiros;

O espaço territorial do quilombo; história das conquistas em relação a posse da terra.

Memórias das relações familiares quilombolas;

Quem são as famílias que compõem a comunidade.

Como se dão as uniões afetivas;

A associação comunitária do Matão

Memórias das festividades; que festas ocorrem na comunidade e na escola. Festas religiosas e pagãs 
(e) Saberes e fazeres dos quilombolas. $4^{\circ}$ bimestre
Memórias dos trabalhos das parteiras da comunidade; plantas medicinais.

Que conhecimentos existem no local, de medicina, de trabalho e conhecimentos que passam de pai pra filho.

Fonte: Elaboração de Marta Oliveira Barros

\section{Considerações finais}

Os resultados de nossos estudos revelaram as experiências de vida desta comunidade quilombola paraibana. Isto fez com que passássemos a valorizar a diversidade de experiências vividas neste local que se expressaram pelas memórias e desejos dos moradores do povoado do Matão. Este estudo também trouxe a luz aspectos que revelavam como se davam as sensibilidades, as emoções e como esses sujeitos lutavam para preservar suas tradições. Percebemos que tudo isso eram saberes locais e que poderiam ser compreendidos como produtores e como parte de culturas singulares, pois se originavam dos conhecimentos do passado na relação com as experiências vividas dos indivíduos que compõem a comunidade. Compreendemos também, que essas experiências eram resultantes de processos de resistência às dominações racistas e excludentes que foram impostos à essas comunidades. Por essa razão, são saberes subalternos que são o resultado das reelaborações de diferentes significações e tradições, bem como possibilitam uma compreensão do mundo de forma muito mais ampla. A partir dessas pesquisas, também criamos e disponibilizamos um quadro de sequências de conteúdos didáticos que podem auxiliar na exploração escolar das diferentes temáticas que fazem parte da constituição das culturas quilombolas. 
Ao fazermos essas ações procuramos revelar diferentes temas que podem ser trabalhados em sala de aula e que expressam formas de resistências, de concepções de mundo e de experiências de trabalho. Partindo dessa perspectiva, pudemos conjuntamente estudar quais eram os livros didáticos de História e Geografia utilizados desta escola, discutindo com as professoras formas alternativas de usos desses instrumentos de ensino. Fizemos isso pois na oficina, também lançamos mão de estudos sobre os tipos de representações iconográficas e textuais que trazem representações sobre os negros e como os conteúdos locais que foram selecionados para serem estudados podem se associar aos temas transversais que fazem parte dos currículos oficiais das escolas. Todas as análises nos confirmaram a ideia de que os processos de exploração econômica sofridos na Paraíba e em especial pelos negros quilombolas, alteraram as vidas dos sujeitos, provocaram mudanças dos seus costumes e modificaram suas práticas de trabalho. Acrescentamos que esta pesquisa pode ainda ser enriquecida por mais depoimentos orais e por documentos impressos, jornais, revistas e iconografias, procurando indícios de correspondências dos saberes produzidos no passado, das ausências e das emergências (BOAVENTURA), ou seja, os saberes e formas de ver o mundo que resistem aos processos de modernização capitalista.

Finalmente entendemos que foi a partir dessas discussões que compreendemos que as memórias dos idosos quilombolas são prenhes de sensibilidades e ressentimentos, revelando que existiram momentos difíceis de opressão e de luta. Além disso, que os silêncios aparentes também poderiam revelar acepções históricas e culturais. 
Desta forma, é aceitável entender porque as memórias dos idosos são importantes no fortalecimento da identidade cultural quilombola, pois suas experiências de vida e seus saberes são fundamentais para que as futuras gerações consigam fazer novas construções sobre história de sua comunidade.

Passamos também a entender que pela escola é possível contribuirmos para a manutenção da cultura quilombola, propiciando por meio dessa instituição a criação das noções de empoderamento dos jovens estudantes dentro de seu contexto sociocultural. Neste sentido o que se aprende na escola está diretamente ligado ao processo de identidade dos estudantes.

\section{Referências}

BARROS, Marta Oliveira. Memórias de Idosos Quilombolas como Recurso didático: Escola Básica do Quilombo de Matão - PB. Dissertação de mestrado. PPGFP/UEPB. Campina Grande - PB.

BENJAMIN, Walter. Magia e técnica, arte e política. Ensaios sobre literatura e história da cultura. 3. ed. Tradução de Sergio Paulo Rouanet. São Paulo: Brasiliense, 1994. (Obras escolhidas; v. 1).

BOSI, Ecléa. Memória e sociedade: Lembranças de velhos. São Paulo: Companhia das Letras, 1994.

CHARLOT, B. Da relação com o saber - Elementos para uma teoria. Porto Alegre: Editora Artmed.2000 
DELGADO, Lucilia de A. N. História oral: memória, tempo, identidades. Belo Horizonte: Autêntica, 2006.

DUSSEL, Enrique. Filosofia de la Liberacion. Bogotá: Editorial Nueva America, 1996.

FREIRE, Paulo. Pedagogia da autonomia: saberes necessários à prática educativa. 43. ed., São Paulo: Paz e Terra, 2014.

Terra, 2005.

. Pedagogia do oprimido. Rio de Janeiro: Paz e FLORES, Elio Chaves. Quilombolas na Paraíba. In:

et al. Diversidade Paraíba: Indígenas, religiões afro-brasileiras, quilombos, ciganos. 1. ed. João Pessoa: Grafset, 2014. v.1. p. 78-109.

HALL, Stuart. The West and the rest: discourse and power. In: Hall et al. (orgs.), Modernity: introduction to the modern societies, Oxford, Blackwell, pp. 185227, 1996.

A identidade cultural na pós-modernidade. Rio de Janeiro, Editora DP\&A, 2014.

HALBWACHS, M. A memória coletiva. Tradução de Beatriz Sidou. São Paulo: Centauro, 2006.

MARCUSCHI, L. A. Análise da Conversação. 5. ed. São Paulo: Ática, 2013.

MOURA, Clóvis. Quilombo: Resistência ao escravismo. São Paulo: Ática, 1987. 
PARAÍBA (Estado). Relatório: I Seminário Estadual de Políticas Públicas para Comunidades Quilombolas do Estado da Paraíba. João Pessoa: Governo do Estado da Paraíba, Secretaria de Estado da Mulher e da Diversidade Humana, dez. 2011. Disponível em: <http:/ / www.cchla. ufpb.br/neabi/pdf/Quilombos\%20(Rel\%202011).pdf>. Acesso em: 15 mai. 2015.

POLLAK, Michael. Memória e Identidade Social. Revista Estudos Históricos, Rio de Janeiro, v. 5, n. 10, 1992.

QUIJANO, Anibal. Colonialidade do poder, eurocentrismo e América Latina. In: SANTOS, Boaventura de Sousa. Um discurso sobre as ciências. 7. ed. São Paulo: ortez, 2010.

THOMPSON, E. P. A miséria da teoria: ou um planetário de erros. Rio de Janeiro: Zahar, 1981. 


\section{TRAVESSIAS E DESAFIOS DA \\ INTRODUÇÃO DOS ESTUDOS DA \\ LÍNGUA PORTUGUESA NO EGITO}

Maged Talaat Mohamed Ahmed Elgebaly ${ }^{1}$

Introdução

“... caminhante, não há caminho, se

faz caminho ao andar ..."

Antonio Machado

Em 2014, criamos o primeiro curso de bacharelado em língua portuguesa e suas letras do Egito, na Aswan University, com o objetivo de formar alunos com habilitação nessa língua. Neste artigo, apresentamos essa experiência, refletindo sobre o papel do ensino da língua portuguesa no desenvolvimento da comunicação intercultural. Analisamos também os problemas encontrados no cultivo do ensino e da aprendizagem dessa língua.

1 Coordenador do Departamento de Língua Portuguesa na Aswan University. Doutor em Estudos Comparados de Literaturas de Língua Portuguesa pela Universidade de São Paulo (2012), doutor em Língua Espanhola pela Ain Shams University (2011), mestre em Linguística pelo Instituto Caro y Cuervo (2005) e bacharel em Letras- Ain Shams University (1999). Tem experiência na área de ensino da Língua Portuguesa e Língua Espanhola e suas respectivas Letras. 
Entre os falantes de árabe e os de língua portuguesa há relações históricas. Os árabes chegaram à Península Ibérica no ano de 711 d.C. e cabe lembrar que, na Era dos Descobrimentos (1415-1543), as primeiras navegações portuguesas partiram do Algarve, ou Oeste de Al-Andaluz, região dominada pelos árabes por séculos e por onde circulavam os povos do Mediterrâneo. Tais vínculos históricos, além das várias levas de imigrantes árabes a países falantes de língua portuguesa, me motivaram a cultivar a introdução do ensino da língua portuguesa no Egito como uma especialidade acadêmica nas universidades egípcias.

Inicialmente, houve várias tentativas de introdução da língua portuguesa na Faculdade de Al Alsun da Universidade de Ain Shams. Nos anos noventa, foi assinado o primeiro acordo entre a Faculdade de Al Alsun da Universidade de Ain Shams e o Instituto Camões para o ensino da língua portuguesa como segunda língua. Em 2006, a Faculdade de Al Alsun da Universidade de Ain Shams recebeu a leitora Prof. ${ }^{a}$. Maria Pinto do Instituto Camões para lecionar o português como segunda língua dentro do departamento de língua espanhola.

Em 1999, me graduei em língua espanhola pela Faculdade de Al Alsun da Universidade de Ain Shams. Três anos depois, tive uma bolsa da Colômbia para fazer o mestrado em linguística. Decidi estudar a língua portuguesa na Colômbia porque não havia ensino dessa língua no Egito naquela época. Minha dissertação de mestrado foi um estudo contrastivo entre as línguas portuguesa e espanhola. Em 2011, obtive o título de doutor em língua espanhola pela Faculdade de Al Alsun da Universidade de Ain Shams, mas queria ter o título de doutor em língua portuguesa para introduzir seus estudos no campo 
acadêmico egípcio. Em 2008, ganhei uma bolsa para fazer o segundo doutorado em Estudos Comparados de Língua Portuguesa na Universidade de São Paulo sob a orientação do Prof. Dr. Benjamin Abdala Junior, professor brasileiro descendente de imigrantes portugueses e árabes. Em 2013, fiz a primeira revalidação egípcia de um Doutorado em Língua Portuguesa e comecei a escrever o Programa do Curso de Bacharelado em Língua Portuguesa. No dia 5 de maio de 2015, o Ministério de Ensino Superior do Egito me autorizou abrir o curso de bacharelado na faculdade de Al Alsun da Universidade de Aswan. Escrevi o projeto considerando os parâmetros curriculares do ensino de línguas no Egito, no Brasil, em Portugal, em Angola e em Moçambique. O Departamento de Língua Portuguesa da Universidade de Aswan lança anualmente um edital para contratar professores de língua portuguesa e suas literaturas.

Começamos a primeira aula no dia 24 de setembro 2014 e formar a primeira turma com bacharelado em língua portuguesa no Egito e em Oriente Médio em junho 2018. Até o fim do ano letivo (2017/2018), o Departamento de Língua Portuguesa tinha 31 estudantes: 2 alunas e 2 alunos no primeiro ano, 7 alunas no segundo ano, 9 alunas e 3 alunos no terceiro ano e as 8 alunas do quarto ano que se formaram este ano.

O curso tem duração de quatro anos letivos, 8 periodos ao final dos quais o estudante obtém o título de Bacharel em Língua Portuguesa e suas letras. As motivações de matrícula dos estudantes egípcios no DLP variam entre as instrumentais orientadas para o trabalho e as integrativas por gostarem de manifestações culturais da língua portuguesa (Gardner, 2007). 
Para acompanhar as novas dinâmicas cibernéticas dos nossos estudantes, criamos o Grupo do Departamento de Língua Portuguesa da Aswan University ${ }^{2}$ no Facebook e no Whatsapp. As interações do grupo do Facebook são bastante dinâmicas e permitem ações como: filiar-se a outros grupos interessados na divulgação da língua portuguesa e suas letras, agendar atividades dentro e fora do grupo, divulgar eventos, fazer novas amizades, bater papo com professores e amigos dos países de língua portuguesa, compartilhar materiais, vídeos e fotos e fazer comentários. Assim, o grupo do Departamento cria hoje um espaço de diálogo entre várias culturas.

Apesar dos laços comerciais existentes entre o Egito e os Países Falantes de Língua Portuguesa (CPLP), a criação do curso de graduação em língua portuguesa foi uma missão que enfrentou certos discursos que atrapalhavam a iniciativa, tais como:
“A língua portuguesa é uma subárea da língua espanhola e por isso seu estudo poderia ser reduzido ao seu ensino como segunda língua (duas horas semanais) no Departamento de Língua Espanhola".

Essa situação deriva da falsa crença popular de que a língua portuguesa é um dialeto da língua espanhola.
“a língua inglesa poderia substituir
a língua portuguesa na comunicação

2 https://www.facebook.com/groups/494171350726055/?fref=ts 
entre Países Árabes e Países Falantes de Língua Portuguesa".

Durante o processo de abertura do departamento em Aswan, resistimos a esses discursos destacando a relevância dessa língua internacional na atual conjuntura mundial e a necessidade de cultivar seu ensino para melhor comunicação e empatia entre os Países Árabes e a CPLP. Também defendemos que nos países da CPLP, a maioria da população não domina a língua inglesa e essa língua aparece como um filtro que não transmite de modo natural as memórias culturais dos falantes de língua portuguesa.

\section{A experiência de ensino da língua portuguesa}

O ensino da língua portuguesa no DLP é construído por uma experiência dinâmica de caráter reflexivo, interativo e intercultural. Na grade curricular, o ensino se dá por meio das seguintes disciplinas:

1. Compreensão e produção oral: onde se ensina fonética, fonologia e pragmática da língua portuguesa (escuta de músicas, entrevistas e documentários e oficinas de conversação em língua portuguesa). Seguindo os pressupostos pedagógicos de Paulo Freire, desenvolvemos as capacidades necessárias para as interações orais. Para isso, elaboramos aulas do sistema fonético da língua portuguesa adaptadas para falantes de árabe, incluindo exercícios de pronúnica na leitura de textos e escuta para completar os sons que faltam. Os alunos enfrentam problemas na aprendizagem do sistema fonológico da língua portuguesa. Por exemplo, temos no treinamento da 
pronúncia das consoantes do português, os estudantes árabes tendem a não distinguir o $b$ do $p$. Ambos são fonemas de mesmo ponto e modo de articulação, mas o $p$ não faz parte do sistema fonológico da língua árabe. Exemplos de erros dos alunos são: núpio no lugar de núbio ou combrar no lugar de comprar. Por isso, recorremos a exercícios com os pares mínimos. No estudo das vogais, foram constatados problemas na distinção entre as vogais abertas e fechadas e na pronúncia dos sons nasais, ausentes também na língua árabe. Contribuem para esses problemas interferências da língua inglesa e francesa. Também, na fase inicial da aprendizagem, os estudantes tendem a confundir a pronúncia dos sons de algumas letras como:

- A letra C antes dos vogais orais /e/e /i/ é diferente de ser antes dos vogais orais $/ \mathrm{a} /, / \mathrm{o} / \mathrm{e} / \mathrm{u} /$.

- A letra G antes dos vogais orais /e/ e /i/ é diferente de ser antes dos vogais orais /a/, /o/ e / $\mathrm{u} /$.

- A letra R no início da palavra e a rr são pronunciadas como /h/ .

- A letra $S$ entre duas vogais tem o som de /z/.

- A letra X pode ser pronunciada de 4 maneiras diferentes $/ \mathrm{S} /, / \mathrm{ks} /, / \mathrm{z} /$ ou $/ \mathrm{s} /$.

- A letra H não é pronunciada.

Para resolver esses problemas e diminuir a ansiedade dos alunos, recorremos à escuta de várias músicas em língua portuguesa. No nível intermediário, os alunos treinam a interação oral em língua portuguesa em variadas situações sociais como as do turismo, das empresas, do jornalismo, da universidade...etc. Na avaliação dessa disciplina, procuramos seguir os critérios das provas orais dos exames de proficiência Celpe-Bras e PLE. 
2. Estudos linguísticos e gramaticais em língua portuguesa: ensinamos nessa disciplina as normas gramaticais da língua portuguesa (morfologia e morfossintaxe). Nessas aulas, utilizamos como material de apoio o livro Falar, Ler, Escrever de Emma Eberlein e Samira Iunes, que se adequa ao modo de aprendizagem com o qual está acostumado o aluno egípcio por ser estrutural comunicativo. O livro é complementado com outras gramáticas. Esses manuais gramaticais são complementados com atividades reflexivas nas tarefas interativas na sala de aula com materiais autênticos. Nas aulas de gramática tentamos articular o material gramatical com a prática dos gêneros textuais. Avaliamos o conhecimento linguístico por meio de tarefas que incentivam os estudantes a colocar em prática as normas gramaticais em situações sociais concretas. Morfologicamente, os alunos apresentaram problemas na aprendizagem do gênero das palavras, especialmente as terminadas em -e, -gem, ou em ditongo nasal. Nem todos os problemas têm a ver com a interferência da língua materna (o árabe), mas ocorreram também problemas com a interferência da língua estrangeira inglês, que interfere na posição de adjetivo antes do substantivo, então casos como Aswan é bonita cidade foram frequentes, por exemplo. No quarto ano letivo, o estudante aprende nesta disciplina também a história da língua da formação da língua portuguesa.

3. Leitura e interpretação de textos: nessa disciplina se ensina a leitura de variados gêneros textuais em língua portuguesa (poemas, músicas, narrativas, notícias, crônicas, contos, romances e filmes, novelas, peças de teatro, artigos, ensaios, dissertações e teses). No nível semântico, 
há problemas nas primeiras aulas de leitura e tradução do português ao árabe devido ao fato dos estudantes terem desenvolvido na sua educação fundamental e secundária uma mentalidade monossêmica, na qual uma forma tem um significado só e um significado tem uma só forma de expressá-lo. Durante as oficinas de leitura, mostramos como um significado pode ser expresso por variadas formas e como uma forma pode ter variados sentidos dependendo do contexto e da situação comunicativa. Assim, passamos gradativamente de uma mentalidade monossémica a uma polissêmica na interpretação dos textos. A avaliação de interpretação dos textos foca nas habilidades gerais de compreensão textual como a identificação do tema e a conexão entre as ideias. A partir do segundo ano do curso, a avaliação tem uma parte que foca na compreensão de um gênero literário como poema, a narrativa e o drama e os conecta a outras linguagens da arte. A avaliação de interpretação dos textos foca nas habilidades gerais de compreensão textual como a identificação do tema e a conexão entre as ideias. No terceiro ano, por meio dos exercícios do livro Via Brasil, começamos a ensinar os processos de formação de palavras em língua portuguesa, usando como referência o livro Estruturas morfológicas da língua portuguesa de Luiz Carlos de Assis Rocha.

4. Redação em língua portuguesa: nessa disciplina se ensina a produção de textos por meio de oficinas de escrita de diferentes gêneros textuais, como artigos, ensaios, currículo vitae, carta de apresentação, e fazemos a correção dessas produções de modo coletivo na sala de aula. Essa disciplina se encontra orientada pelas propostas de Luiz Antonio Marcuschi (2008). Nesse processo de redação, é 
interessante como o estudante vai aprendendo a diferenciar entre os usos orais e os escritos na sua própria língua mãe, o árabe, antes de transferir o aprendizado dessa diferenciação ao uso da língua portuguesa.

5. Tradução do português ao árabe e do árabe ao português: disciplina na qual se ensina a transferência de diferentes gêneros textuais de uma língua para outra. Inicialmente, o estudante aprende noções da línguística contrastiva entre a língua árabe e a língua portuguesa como a ordem da oração em árabe (Verbo+Sujeito) e em português (Sujeito+Verbo). Ademias, aprende-se princípios de terminologias das humanidades, e uso dos diferentes dicionários de língua portuguesa e da língua árabe. Também, o estudante aprende articular seus saberes adquiridos na disciplina de leitura e interpretação de textos com a de redação para passar a aplicar nessas duas instâncias as técnicas de tradução de textos de diferentes domínios sociais.

\section{Metodologia de pesquisa em língua portuguesa e}

suas letras: abordamos problemas linguísticos, literários e de tradução, propostos pelos alunos a partir de uma ótica comparativista, intercultural e interdiciplinar. Também nessa disciplina aplicamos oficinas de produção textual dos mais variados gêneros acadêmicos.

\section{História de Literaturas de Língua Portuguesa:}

que vamos apresentar com mais detalhes na seguinte parte sobre o ensino das literaturas de língua portuguesa. Nessa disciplina o estudante desenvolve sua competência intercultural. Incialmente, o estudante vem com um olhar 
que reduz sua interpretação da realidade a partir da ótica cultural local, depois passa a entender os processos culturais que produziram, ao longo dos diferentes períodos históricos, as mudanças nas visões artísticas nos países de língua portuguesa e chega a adquirir paulatinamente um olhar intercultural que compreenda e entenda as diferenças culturais.

Como prática das instituições universitárias egípcias, no final de cada semestre, os estudantes são submetidos a provas. Por isso, buscamos elaborar avaliações que possam explorar o conhecimento do aluno sobre a língua portuguesa e suas manifestações culturais e históricas, com perguntas de análise e de crítica e que impliquem a relação entre as ideias históricas e teóricas e as práticas da língua nas mais variadas situações sociais.

\section{Ensino das literaturas de Língua Portuguesa}

O Departamento adota a visão de Antonio Candido da literatura como um direito humano. Quando o estudante termina a metade do livro Falar, Ler e Escrever, já começa a ter um nível que oscila entre o elementar e o intermediário, o que nos permite iniciar o ensino das literaturas de língua portuguesa. Os estudantes começam, portanto, a ter contato direto com as disciplinas de literatura a partir do segundo ano letivo (terceiro semestre do curso). No currículo, a literatura consta basicamente nas disciplinas de Leitura e Interpretação de textos e História da literatura, que visam desenvolver a capacidade literária dos estudantes. Na disciplina Leitura e interpretação de textos ensinamos os tipos textuais como a descrição, a narração e a argumentação. Na disciplina História das literaturas de 
Lingua Portuguesa estudamos diferentes épocas da história da literatura portuguesa, brasileira e aspectos das literaturas africanas e asiáticas em língua portuguesa, da Idade Média até a Contemporaneidade. Em cada etapa, o aluno aprende os principais conceitos históricos característicos de cada época, os autores e as obras relevantes de cada período literário.

Nas primeiras aulas, os estudantes começam a assimilar pouco a pouco a terminologia literária em geral e dos conceitos da história da literatura luso-brasileira em especial. Nessa fase, vamos apresentando as principais técnicas operadoras na leitura dos variados gêneros literários (narrativa, poesia, drama, etc).

Também tentamos dedicar aulas específicas para questões teórico-conceituais e técnicas, como as figuras da linguagem, as técnicas da poesia e da pintura, as da narrativa e do cinema e as do drama, do teatro e da novela. Ao decorrer da análise literária de textos escolhidos pelos próprios alunos de uma lista sugerida pelo programa de diferentes escritores, vamos apresentando as questões teóricas da crítica literária.

Um dos desafios no estudo do ensino da literatura é a hegemonia do pensamento pragmático centrado no eu consumidor. Por isso, ao início, afirmamos a reflexão literária produtora de sentido de vida. Aos poucos, o estudante começa a sentir o gosto da experiência literária e sua relevância para a compreensão da sua realidade.

Inicialmente, os estudantes questionam as diferenças culturais na literatura e se confrontam com diversos modos de percepção dessas diferenças. Muitas vezes são questionados na sala de aula temas de gênero, como o tipo de vestimenta, as relações sociais da mulher e seu 
papel na sociedade. Também, são criticados os olhares eurocêntricos sobre os árabes, os negros, os índios e os asiáticos, promovendo um pensamento crítico e de respeito à diversidade cultural. No decorrer dessas aulas, procuramos cultivar o debate amigável e desenvolver a capacidade argumentativa do estudante, propiciando um ambiente agradável e aconchegante, com petiscos, café ou chás, para administrar ludicamente as tensões que podem surgir nas discussões e incentivar positivamente a experiência de diálogo com o outro, como defendia Paulo Freire (1967, p. 90) :

\begin{abstract}
“Uma educação que possibilitasse ao homem a discussão corajosa de sua problemática... Educação que o colocasse em diálogo constante com o outro... À análise crítica de seus 'achados".
\end{abstract}

Ao longo do curso, procuramos reparar as lacunas no conhecimento dos principais acontecimentos da história mundial e, especialmente, aqueles que influenciaram a literatura luso-brasileira contemporânea, tal como o movimento de contracultura, ou, por exemplo, as consequências da primeira e da segunda guerra mundial. Por essa razão, tentamos valorizar a literatura como uma porta de entrada para os alunos conhecerem o próprio contexto social em que estão inseridos. Na medida em que vamos ampliando o repertório de variadas referências históricas, os estudantes vão deixando de considerar o seu repertório local como o único no mundo para produzir um olhar plural e crítico que considere as diferenças 
culturais e se alimenta desta diversidade. Nesse sentido, recorremos à estratégia das excursões a variados lugares históricos no Egito, fora do espaço habituado do estudante, o que representa um avanço na ampliação do seu repertório.

Outra estratégia que utilizamos foi a promoção de visitantes falantes de língua portuguesa para desenvolver atividades culturais e de pesquisa com os estudantes. Ao mesmo tempo, organizamos a I, II e III Jornadas de Língua Portuguesa. A primeira foi em 2015 com a visita do Prof. Dr. Benjamin Abdala Junior, que falou sobre as fronteiras múltiplas na literatura. A segunda foi em 2016, com a visita do Prof. Dr. José Clécio Quesado, que nos falou sobre aspectos gerais da literatura portuguesa. No mesmo ano, organizamos oficinas de leitura. A terceira jornada de língua portuguesa foi no dia 4 abril de 2016 com participação de delegações da Angola, Brasil, Moçambique e Portugal. Nessas jornadas, procuramos o maior diálogo possível entre os representantes dos países da CPLP sobre o ensino da língua portuguesa no exterior.

A ampliação do repertório dos estudantes e o desenvolvimento da experiência intercultural lhes permite superar o olhar fragmentário, próprio das restrições sociais, e começar a se apropriar de uma perspectiva holística da realidade a partir de uma ótica que considere as novidades das ciências humanas e sociais. Benjamin Abdala Júnior (2012) destaca:

A historiografia assim entendida não se volta apenas para o que já foi, mas recupera a memória em seu processo para projetá-la para o futuro. Este, 
para Ernst Bloch (1976), afigura-se como um princípio de esperança uma forma de utopismo ontológico onde o homem, ativo e inquieto, sente-se desejoso de aperfeiçoamentos futuros.

Assim, com o ensino e a aproximação dos processos históricos das literaturas de língua portuguesa, vemos nascer no estudante a desconstrução gradual das atitudes provincianas fechadas, o desenvolvimento de diálogos internos entre a cultura secular e a religiosa e o pensamento crítico das tradições das gerações mais velhas; a abertura às diferenças culturais e a reflexão intercultural sobre sua realidade, seu corpo e os contrastes sociais. Dessa maneira, o contato dos alunos egípcios com as literaturas de língua portuguesa apresenta uma reinterpretação dos valores éticos e estéticos da sua realidade.

Cabe ressaltar que os alunos desenvolveram, a partir das aulas da História das literaturas de lingua portuguesa, uma série de reflexões que participam, portanto, do desenvolvimento emocional e social da personalidade dos estudantes. Nesse sentido, o professor Benjamin Abdala Júnior (2012) afirma:

A história da literatura deve ser vista, entendemos, nessa plurivocidade discursiva, com relatos entrecortados, conflituosos, como matéria voltada para o antes que pode vir a ser o depois. No enovelado de linhas que se embaraçam, torna-se necessário se buscar ainda intersecções 
e confluências com conjuntos de outros repertórios, sem perder a especificidade do modo de se conhecer a realidade que vem da literatura.

A avaliação da disciplina História das literaturas de língua portuguesa é feita com perguntas dissertativas. Em todo o processo da avaliação, nosso principal objetivo é a orientação e não a penalização, por isso recorremos a um caminho mais construtivo a partir da experiência que traz o estudante para a sala de aula.

\section{Considerações finais}

Ao longo do nosso relato, mostramos aspectos do ensino da língua portuguesa e de suas literaturas no curso de Línguas do Departamento de Língua Portuguesa em Aswan University, no Egito. Essa experiência nos mostrou variados tipos de diálogos interculturais. Temos o diálogo não somente entre os falantes de língua árabe e os de língua portuguesa, mas também o diálogo interno entre os membros da CPLP e seus cânones literários legitimados.

Nessas interações, emerge a problematização da canonização literária no currículo, mas surge também o diálogo entre falantes de língua portuguesa e os do resto dos países Iberoamericanos, entre os falantes de língua portuguesa e outros do continente americano, europeu e asiático. Todo esse processo apresenta o potencial de conduzir a formação de novos leitores das literaturas de língua portuguesa em espaços inéditos e promissores. Observa-se que os desafios que enfrenta a implantação da língua portuguesa nesses espaços inéditos nem sempre 
são linguísticos-culturais, mas há outras questões institucionais e políticas que poderiam comprometer o desenvolvimento das estratégias de aprendizagem e comunicação.

Assim que esses desafios se agravam com a situação geopolítica instável que vive o mundo, termina abalando a motivação dos professores e estudantes, o que compromete todo o processo pela falta de apoio material. Nesse sentido, evocamos as palavras do ilustre escritor moçambicano Mia Couto (2017): “Falar, amar e cultivar o português é uma forma de militância pela diversidade". Por isso, inspirados na experiência relatada do Departamento de Língua Portuguesa da Universidade de Aswan, as direções das Universidades de Al Azhar, de Ain Shams, de Helwan e do Cairo solicitam o Programa do Curso de Bacharelado em Língua Portuguesa e suas literaturas da Universidade de Aswan para a criação de novos bacharelados em língua portuguesa em suas instituições.

\section{Referências}

ABAURRE, Maria Luiza; Pontara, Marcela Nogueira (2015). Gramática - Texto: Análise e Construção de Sentido. São Paulo: Editora Moderna Plus.

ABDALA JUNIOR, Benjamin (2012). Literaturas em Lingua Portuguesa: histórias e estórias. Matraga (Rio de Janeiro), v. 19, p. 10-24.

CANDIDO, Antonio (1989). Direitos Humanos e literatura. In: A.C.R. Fester (Org.) Direitos humanos. São Paulo: Ed. Brasiliense. 
Candido, Antonio (1995). O Direito à Literatura. In: Vários Escritos. São Paulo: Duas cidades.

COSSON, Rildo (2009). Letramento literário: teoria e prática. São Paulo: Contexto, 2007.

CUNHA, Celso; Cintra, Lindley. Nova Gramática do Português Contemporâneo. Rio de Janeiro: Editora Lexicon.

De Nicola, José (2011). Painel da literatura em língua portuguesa. São Paulo: Editora Scipione.

ELGEBALY, Maged T. M. A (2016). Apontamentos sobre o ensino de literaturas de língua portuguesa no Egito. In: Anais do II Congresso Internacional de Linguística e Filologia (CILF) do Círculo Fluminense de Filologia e Lingüística (CiFEFiL) na Universidade Veiga de Almeidas (UVA), Rio de Janeiro, v.XX. p.94- 100.

FREIRE, Paulo (1967). Educação como prática de liberdade. Rio de janeiro: Paz \& Terra,

GARDNER, Robert C (2007). Motivation and second language acquisition. Porta Linguarum 8, 9-20.

GELBERT, Laura e Grayley, Monica. Entrevista com o Mia Couto- Falar português é 'militância pela diversidade', diz Mia Couto em dia mundial. ONU News no Brasil, 2017. https://nacoesunidas.org/falar-portugues-e-militancia-pela-diversidade-diz-mia-couto-em-dia-mundialAcesso:4/09/2017 
LIMA, Eberlein.E.O.F.; Iunes, Samira. A (1999). Falar... Ler... Escrever... Português: um curso para estrangeiros. São Paulo: E.P.U.

MAINGUENEAU, Dominique (2005). Discurso literário. Tradução de Sírio Possenti. São Paulo, editora contexto.

MARCUSCHI, Luiz Antonio (2008). Produção textual, análise de gêneros e compreensão. São Paulo: Parábola Editorial.

MONTEIRO, Pedro Meira (Org.) (2014). A primeira aula. Trânsitos da literatura brasileira no estrangeiro. São Paulo: Itaú Cultural.

ROCHA, Luiz Carlos de Assis (2012). Estruturas Morfológicas do Português. São Paulo: Martins Fontes.

SAID, Edward (1978). Orientalism. London: Penguin. Said, Edward (2003). Reflexões sobre o exílio e outros ensaios. São Paulo: Companhia das Letras.

SANTIAGO, Silviano (2000). Uma literatura nos trópicos: ensaios sobre dependência cultural. Rio de Janeiro: Rocco.

SARAIVA, José F. S. (1996) O lugar da África: a dimensão atlântica da política externa brasileira (de 1946 a nossos dias). Brasília: Editora UNB.

SARAIVA, José F. S. (2015) A África no século XXI: um ensaio acadêmico. Brasília: Fundação Alexandre Gusmão.

TAKAHASHI, Neide Tomiko (2015). Leitura Literária em português-lingua estrangeira (PLE) no Brasil: representações, compreensão e produção textual. Tese de Doutorado. 
Orientadora: Prof ${ }^{a}$. Dra . Rosane de Sá Amado, FFLCH, USP, São Paulo.

TAKAHASHI, Neide Tomiko (2008). Textos literários no ensino de português-língua estrangeira (PLE) no Brasil. Dissertação de Mestrado. Orientador: Prof. Dr. Reginado Pinto Carvalho, FFLCH, USP, São Paulo. 


\title{
Sobre o livro
}

\section{Projeto Gráfico e Editoração Leonardo Araujo \\ Capa Erick Ferreira Cabral}

\author{
Impressão Gráfica Universitária da UEPB \\ Formato $15 \times 21 \mathrm{~cm}$ \\ Mancha Gráfica $\quad 10,3 \times 16,5 \mathrm{~cm}$ \\ Tipologias utilizadas Book Antiqua 11,5
}


A visão dicotômica entre as práticas sociais produzidas no contexto offline (real) e online (virtual), definitivamente, não faz mais sentido no mundo contemporâneo. Estamos vivendo um contexto de práticas sociais híbridas em razão do encurtamento, cada vez mais acentuado, entre 0 que vivenciamos e produzimos na sociedade, em decorrência dos avanços alcançados pelas tecnologias da informação e da comunicação nos últimos 25 anos.

Trata-se de um fenômeno que confere à sociedade atual uma natureza ainda mais dinâmica e complexa e na qual precisamos nos reorganizar e adaptar, pois, dada a sua força, está nos compelindo para que (res)signifiquemos nossas práticas sociais, ideias, conceitos, interpretação e nos impondo novas experiências no saber, no fazer, no sentir, no pensar etc. Em outras palavras, já não temos mais como nos sustentarmos em estruturas institucionais e práticas sociais historicamente sedimentas na cultura humana, pois elas estão se liquefazendo a cada dia, como argumenta Bauman (2001). 